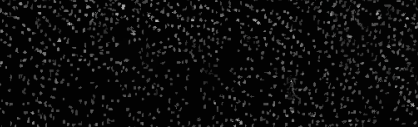

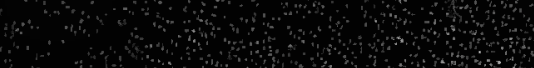

a d

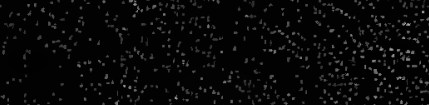

(1) 
NUNC COGNOSCO EX PARTE

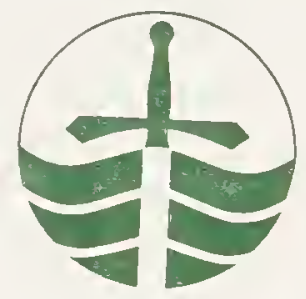

THOMAS J. BATA LIBRARY TRENT UNIVERSITY 
Digitized by the Internet Archive in 2019 with funding from Kahle/Austin Foundation 





\section{Sand Dunes and Salt Marshes}






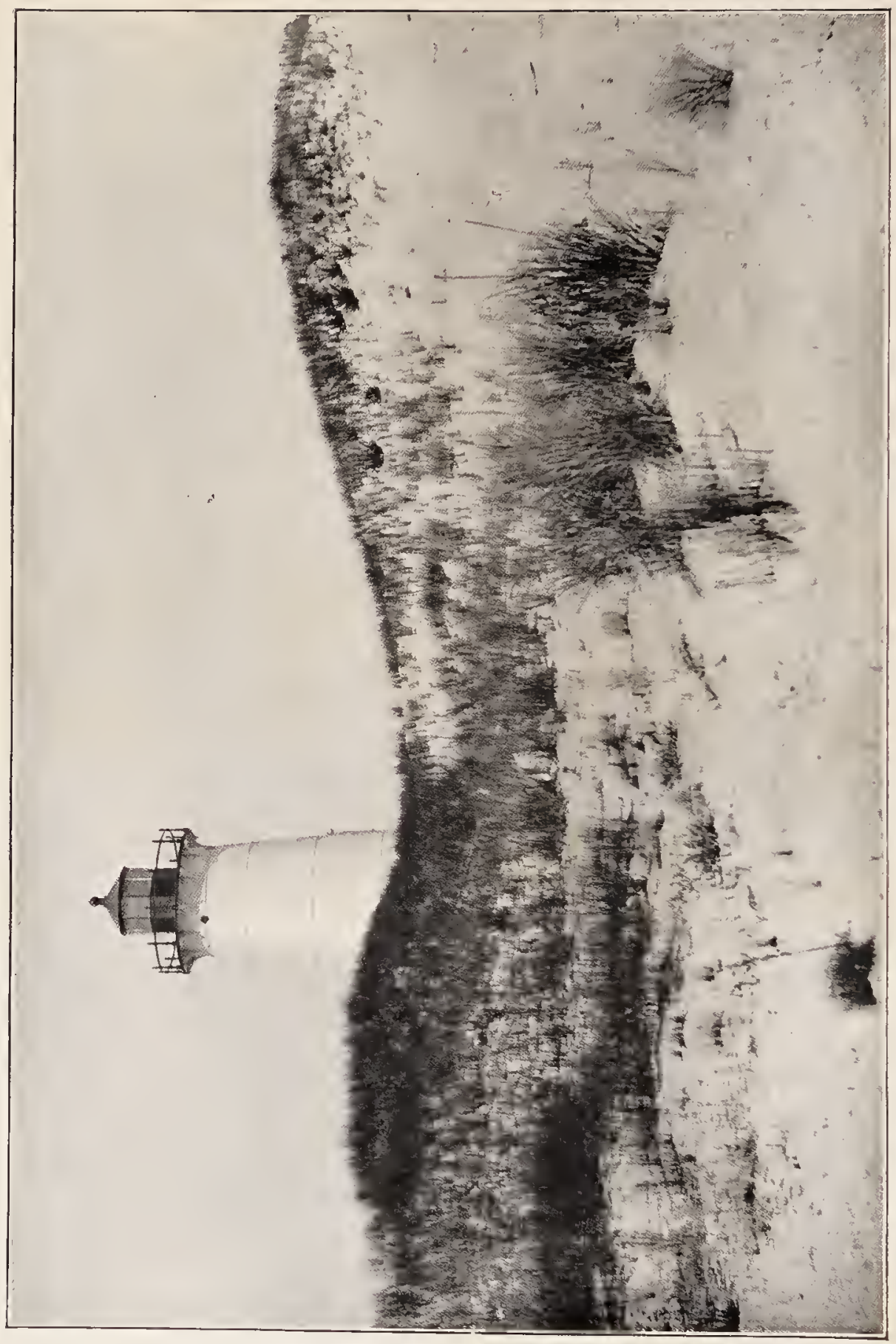




\section{"SAND DUNES AND}

SALT MARSHES

BY

CHARLES WENDELL TOWNSEND, M. D.

Author of "The Birds of Essex County," "Along the Labrador Coast," "A Labrador Spring," and

"Captain Cartwright and His LABRADOR JoURNAL"

With numerous Illustrations from Photographs

BOSTON

THE PAGE COMPANY

PUBLISHERS 


\section{Copyright, 1913 \\ By Dana Estes \& Company \\ All rights reserved}

THE COLONIAL PRESS

C. H. BIMONDS \& CO., BOSTON, U. 8. A. 
10 ${ }^{\text {To }}$

330141 



\section{PREFACE}

T N 1767 Gilbert White complained that he had none to share his tastes in natural history. He says: "For want of a companion to quicken my industry and sharpen my attention, I have made but slender progress in a kind of information to which I have been attached from my childhood." In these modern days, nature students are numerous and I have been blessed with friends who have appreciated to the full these dunes and marshes of Ipswich.

For the last twenty years I have spent most of my summer vacations at Ipswich and have made brief visits there as often as I could at other seasons, while almost twenty years before that the birds of this Massachusetts coast began to claim my attention.

The opportunities for study are large in these regions, and my excuse for not having gone deeper in all these years, is that I have been of necessity a brief bird-of-passage in 


\section{PREFACE}

the dunes and marshes, but even with visits of a day's duration one can in time cover every date in the calendar.

The formation of sand dunes and salt marshes is much the same the world over, while the animal and vegetable life of these regions is very similar on both sides of the North Atlantic. This book, therefore, should be of general and not merely local value, and is addressed to all lovers of seashore dunes and marshes and of their wild inhabitants.

I wish to express my indebtedness to Mr. Walter Deane for botanical identifications, and to Dr. Glover M. Allen for the identifications of mammals. In matters ornithological I have tried to hold my own with several good friends, among them Mr. William Brewster, Dr. Walter Faxon, Mr. Ralph Hoffmann, Mr. Francis H. Allen, Dr. Glover M. Allen and Mr. A. C. Bent, all of whom at times have shared with me the pleasures of these regions.

Chapter XI, slightly modified, has already been published in the $A u k$ of July, 1912, and I am indebted to the editor for permission to republish here.

Most of the illustrations are from my own photographs, but I am indebted for several to 


\section{PREFACE}

Dr. Glover M. Allen and to Mr. J. H. Emerton, and for one each to Mr. J. T. Morse. Jr., and to Mr. F. B. McKechnie. To Mr. R. T. Crane, Jr., I am indebted for the photographs of the old maps. I wish also to express my thanks to Dr. Robert Swift for his drawings of seals and mushrooms, and to Dr. Glover M. Allen for his great kindness in reviewing the manuscript. To my wife and eldest daughter I am especially indebted for much patient and kindly criticism.

I have omitted all scientific names of animals and plants from the text, but those so inclined will find them in the index.

I have sometimes been asked what I found of interest in the dunes and marshes. This little book is the answer.

Boston, January, 1913. 



\section{CONTENTS}

CHAPTER

PAGE

Preface . . . . . . . . . . vii

I. SAND DUnes . . . . . . . 11

II. Tracks and Tracking . . . . . 38

III. VegetTAtion IN THE DUNes . . . . 70

IV. LAND Birds OF THE Dunes . . . . 86

V. Swallow Roosts and Swallow MigraTION . . . . . . . . . . 111

VI. Water Birds Seen From the Dunes . 123

VII. The Harbor SEal . . . . . . 160

VIII. SAlT Marshes . • . . . . . . 188

IX. Salt Marshes - Their Past and Future 206

X. Birds of the Salt Marshes . . . 229

XI. The Horseshoe Crab and other Denizens OF SAND AND MUD . . . . . 252

XII. Bird Genealogy . . . . . . 278 INDEX . $\quad . \quad$. $\quad . \quad$ • . 303 



\section{LIST OF ILLUSTRATIONS}

The Lighthouse in the Dunes . . . Frontispiece The Beach and the Sea from the Dunes . . 12 The Lighthouse in the Sea of Dunes . . . . 14 A Small Amphitheater in the Dunes . . . . 16 Dunes Showtng Wind Stratifications and Steep WINDWARD FACES . . . . . . . . . 18 Pitch Pines After the Dune Has Passed. . . 20 Pines Overwhelmed by the Advancing Dune . 20 ON the Edge of the Beach . . . . . . . 22 A Peaked Dune . . . . . . . . . 24

Showing Both the Steep Windward Face By Cutting, and the Gentle Wind - swept Slope . . 24 The Old Lighthouse Keeper and Some of His FrIENDS . . . . . . . . . . 26

Wreck Uncovered After Many Years Far in the Dunes, Showing also Ripple - Marks . . . 26 The Half- Buried Apple Orchard in 1892 . . $\quad 28$ All That Remained of the Orchard in 1910 . 28 Map of Castlit Hill Farm, 1846 . . . . 30-31 Map of IPswich Sand Dunes, 1786. . . . . . 32 "Glacier Dune" Showing the Cracked Sand and THE UNDERLYing SNOW . . . . . . . 34

Dune Overwhelming Birch Grove, Showing the Steep Leeward Side . . . . . . . 34 ICE WALL . . . . . . . . . . . 36 


\section{LIST OF ILLUSTRATIONS}

ICE WALL • . • • . . . • . • • 36

Wreck on the Beach Above the Ice Wall . 38

$\mathrm{I}_{\mathrm{CE}} \mathrm{W}_{\mathrm{ALL}}$. . . . . . . . . 38

Deer Tracks . . . . . . . . . . 40

JACk Rabbit Tracks, Ipswich, 1903 . . . . 40

Tracks of Fox AND Crows . . . . . . 46

Muskrat Tracks . . . . . . . . . . . 46

TRACKS OF TOADS . . . . . . . . . 50

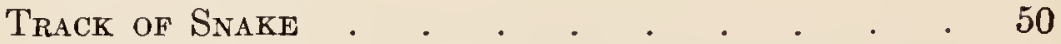

Track of Meadow - mouse and of a Woolly Bear

Caterpillar . . . . . . . . 52

Tracks of White - Footed Mouse . . . . . 52

SkUnk Tracks . . . . . . . . . . 56

Tracks of a SkUnk in a HURRY . . . . . . 56

Tracks of a Crow . . . . . . . . 60

Hudsonia Plants, Tracks of White-footed Mouse ANd of Pheasant in Soft Sand . . . . 60

Tracks and Eggs of Piping Plover . . . . 62

Tracks of Savannah Sparrow and Sand Dune Spider

AND Hole of LatTer . . . . . . . 62

Tracks of Horned Larks. - Seaside Goldenrod . 64

Tracks of Snow Buntings. . . . . . . 64

Staghorn Beetle and Tracks . . . . . . 68

Tracks of Sand Dune Grasshoppers . . . . 68

Grove of Pitch Pines . . . . . . . 70

Clumps of Fruiting Beach Grass. The Tips of Buried

Pines Bearing Cones May be Seen in the ForeGROUND . . . . . . . . . 70

Seaside Goldenrod . . . . . . . . . 74

The Brown Mushroom of the Dunes. - Sand - star

Puffball . . . . . . . . . . . 76

A Cranberky Bog in the Dunes with Single Pitch

Pine . . . . . . . . . 78

Cranberry Vines on the Sand ... . . . . . . . 78 


\section{LIST OF ILLUSTRATIONS}

Beach Plum Bushes at Plum Island . . . . 80

BAYBerRy IN WiNTER . . . . . . . . . 82

Hudsonia and Advancing Dune . . . . . 82

Dinner in the Lee of the Pines . . . . . 84

The Road to the Lighthouse . . . . . . 94

The Dunes in Summer . . . . . . . . 102

The Dunes in Winter . . . . . . . 102

Tree Swallows Investigating a Birdhouse . . 112

Nests of Eave Swallows on an Old Barn * . 112

An ANgler Fish Thrown Up oN the Beach . . 126

Tracks of Herring Gull Made on Aimghting on the

$\mathrm{BEACH}$. . . . . . . . . . 126

Herring Gullis in the Ipswich Dunes . . . . 128

The Wreck of the SAND Schooner . . . . 136

The Wreck a Year Later . . . . . . 136

Courtship Pose of Shelldrake. - Courtship Poses

of Whistler . . . . . . . . . . 146

Watching Water Birds and Seals from the Wreck 156

Skull of Dog and of Seal. - Grass Balls . $\quad 156$

Group of Hair Seals from Ipswich . . . . 164

Harbor Seals . . . . . . . . . . 168

"Cetus Capillatus" and "Monstrum Marinum". 182

A Creek in the Marshes . . . . . . . . 188

Cutting the Marsh Hay . . . . . . . 192

Bringing iN the Marsh HaY . . . . . . 194

Harvesting the Marsh Hay . . . . . . . 196

Haystacks in the Broad Marsh . . . . . 198

High Tide. - Taken by the Light of the Fuli Moon 200

A Staddle in the Marsh . . . . . . . 200

Low Tide . . . . . . . . . . . . 202

High Tide . . . . . . . . . . 202

Marsh Islands $. \quad . \quad . \quad . \quad . \quad . \quad . \quad . \quad 204$

The Marsh in Winter . . . . . . . 204

The Marshes and Hog Island, High Tide . . . 210 


\section{LIST OF ILLUSTRATIONS}

PAGE

Thatch Grass Building Out on the Eddy Side of a

CreEK . . . . . . . . . 216

The Bank Falimg Away on the Channel Side of a

CREeK . . . . . . . . . . 216

Islands of Thatch at Low Tide . . . . . 218

Marsh and Creek at High Tide . . . . . 218

A Marsh Island . . . . . . . . . 224

The Old Canal . . . . . . . . . 224

Young Bitterns . . . . . . . . . 234

In the Upper Reaches of the Castle Neck River . 240

Group of Birds of the Marsh . . . . . 244

The Gunner's Blind and Decoys at the Slough • 248

Horseshoe Crabs . . . . . . . . 252

Rock Crabs and Their Tracks . . . . . 252

Mounds Made by Beach Fleas . . . . . 256

Circles Made by the Grass Blown by the Wind . 256

Whelk, Sea Snail, etc. . . . . . . . 270

Northern Quahog, Sea Mussel, etc. . . . . 270 


\section{Sand Dunes and Salt Marshes}

\section{CHAPTER I}

\section{SAND DUNES}

"Till the sand was blown and sifted Like great snowdrifts o'er the landscape, Heaping all the shore with sand dunes."

- LONGFELLOW.

CAND dunes have a fascination all their 1 own. In the multiplicity of their forms and colors, varying with the seasons and years, they are a constant source of pleasure, while in their wealth of plant and animal life their interest is never-ending. The beauty of the sand dunes is revealed at every turn, their secrets are legion. The course of their formation from the time they emerge out of the sea as reefs washed by every tide, until they have reached perfection in their wave-like erests fifty feet high is an absorbing study. Their 


\section{SAND DUNES AND SALT MARSHES}

surface records a continually changing story, -ripple-marks of the varying winds, magic circles made by the grass, and myriad tracks of living creatures.

A day spent in the dunes

" On the firm packed sand,

Free

By a world of marsh that borders a world of sea,"

with the roar of the waves and the cries of the gulls in one's ears, the breath of the marsh and of the ocean in one's nostrils, the wild beauty and loneliness of the scene in one's eyes, is indeed an inspiration, a memory worth treasuring.

"There is a rapture on the lonely shore, There is society where none intrudes, By the deep Sea, and music in its roar."

The reefs along the beach are constantly changing. One of these I have watched and recorded since 1892. When first seen, it was already above high tide except at its northwest extremity, and connected with the beach off the Ipswich range-light. Like other reefs, its slope was gradual on the seaward, steep 


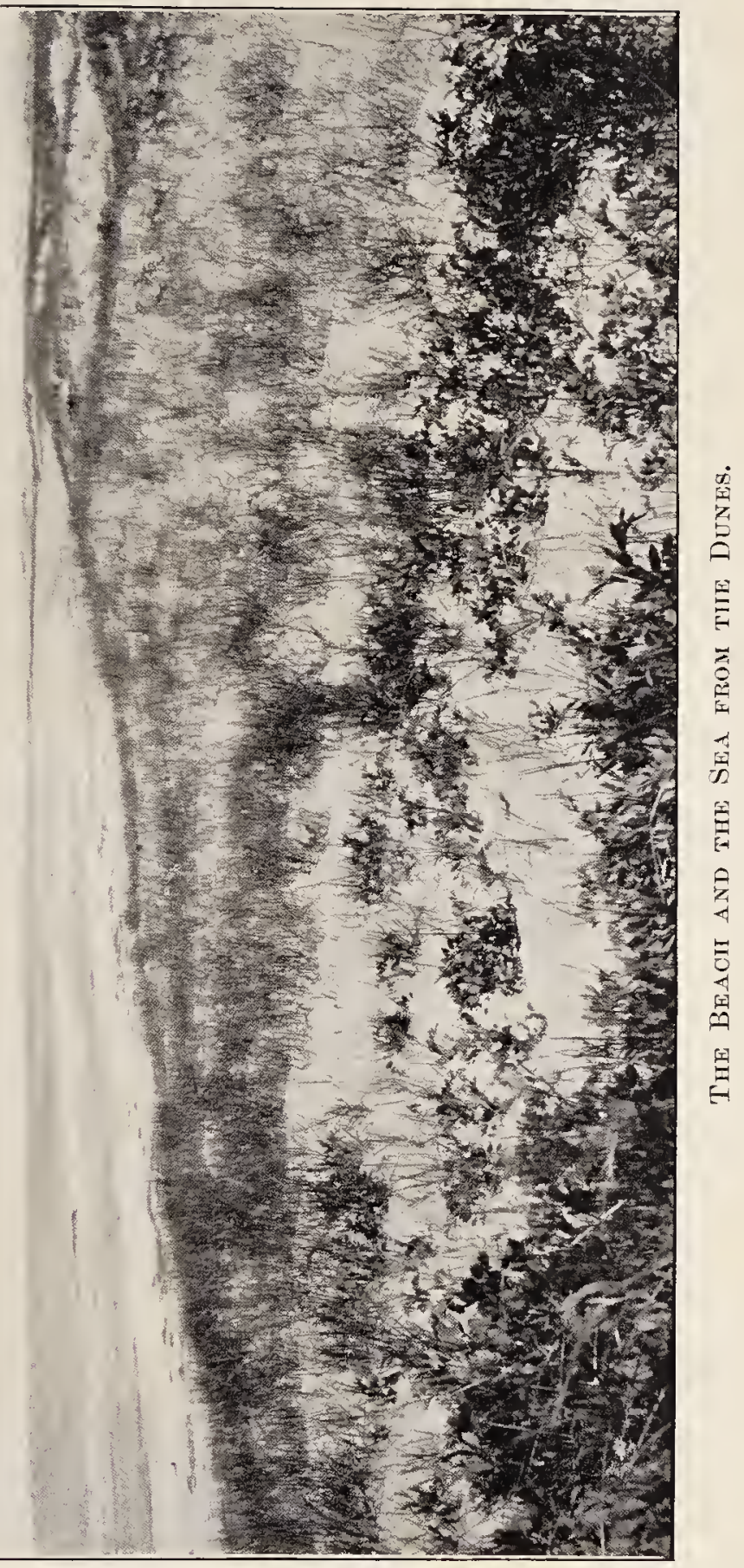





\section{SAND DUNES}

on the landward side, and so narrow that I used - in those barbaric days - to build my blind in the middle of the spit and shoot over decoys placed at the water's edge on both sides.

As the sea threw up more and more sand, and the wind seized it and blew it inland, the spit extended and broadened and cut off a lagoon of several acres in extent, so protected from the sea waves that a different marine life flourished there. It was a godsend to the old lighthouse-keeper, for he could dig at his door all the clams he needed without having to wend his way to the inland creeks. This was the only place on the outer side of the dunes where common clams were found, for on the unprotected beaches the massive seaclam, an entirely different species, alone flourishes. The spit grew year by year, and in 1904 had become an elevated plain three hundred yards broad, which completely enclosed the shrunken lagoon, now brackish and stagnant. The clams had all died and another set of inhabitants flourished there, dominated by great masses of slimy algae. But the sands kept blowing, and in 1906 the pool was entirely effaced. Clumps of beach grass ap- 


\section{SAND DUNES AND SALT MARSHES}

peared in places, and the sand collected about them and formed the beginning of dunes.

Later, owing to some change in the currents along the shore, the waves demolished their own handiwork, and in 1908 veritable subfossils, the shells of the common clam, began to appear on the outside beach, standing in place with their empty valves pointing upward as in life.

While clumps of beach grass are often responsible for the birth of a dune as just described, any obstacle or irregularity, in whose lee the heavier grains of sand settle, may also start a dune on its progress. However started, their forms are many and various, yet, as they are all dependent on the winds, they are shaped by the strongest or dominant ones, and these are the winds which blow from the northwest, north and northeast, during the winter months. Certain secondary or transient modifications are due to other winds, particularly to the prevailing southwest breezes of summer, but a visit to the dunes in a snow-spitting northeaster of winter gives one an idea of aeolian power not often realized in the gentler summer season. Smiling skies, gentle balmy breezes, flowers 


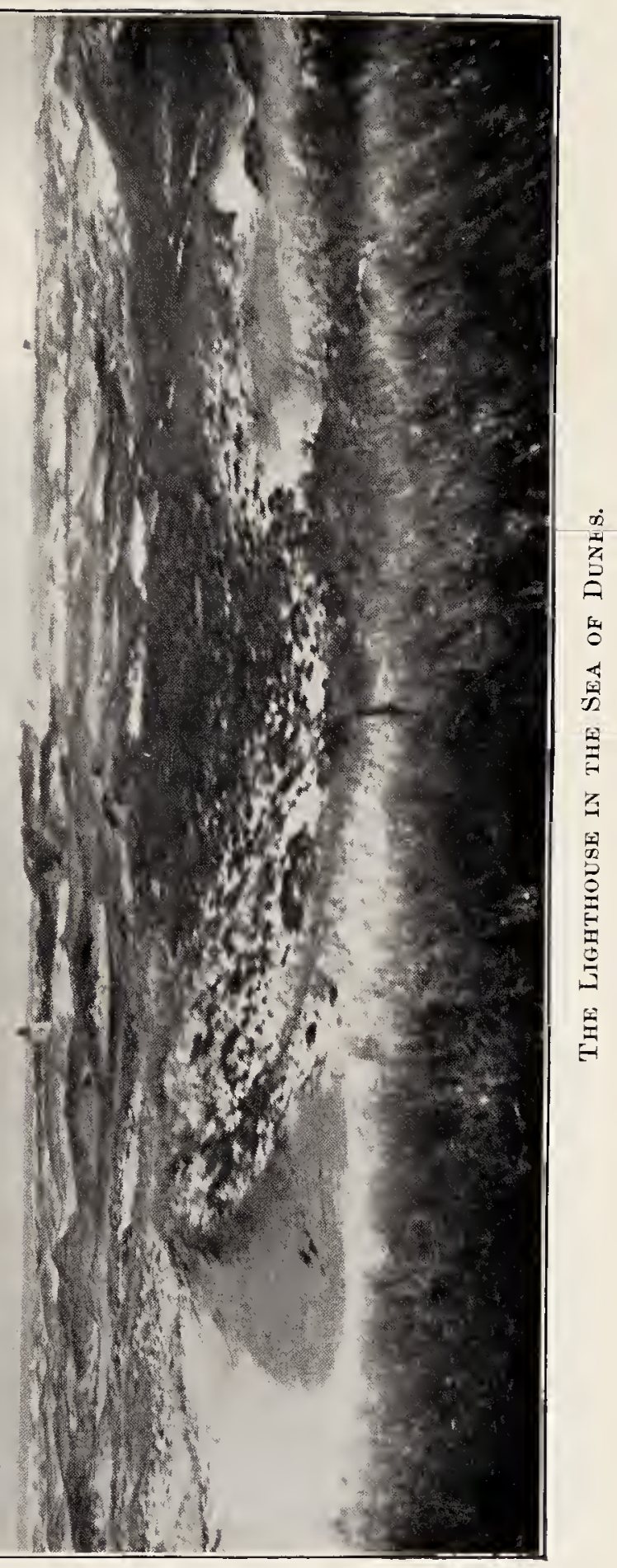





\section{SAND DUNES}

blooming and filling the air with their perfume, bird songs ringing from every clump of bushes and grove of trees, perfect gems of color in a setting of brilliant white sand,all of these are seductively enchanting. But the full glory of the dunes, to my mind, is to be found in the winter storms, when the biting wind sweeps with resistless force over them, driving snow and sand into the face of the toiling dune traveller, when the gulls scream noisily overhead, and flocks of ducks, restless in the foaming seas, scud by before the blasts, while over all the roar of the waves, pounding relentlessly on the beach, sounds a grand sea dirge. As one pauses for breath in the lee of a dune and watches the clouds rush by over the tumultuous ocean of sand, one feels to the full the primeval grandeur of the dunes and sees them in their true colors and stormy activities.

Ripple-marks form on the surface of the sand whenever it is dry and the wind blows. These are parallel ridges athwart the wind, with steep sides to leeward, gradually sloping ones to windward. Similar ripple-marks are left by the receding waves on the beach, or by the sweep of the tides in the estuaries, or 


\section{SAND DUNES AND SALT MARSHES}

by the rush of the brook to the sea. In the estuary the steep side of the ripple-mark is up-stream on the flood and down-stream on the ebb tide. In the bed of both water and wind stream the grains of sand are pushed along in parallel ridges up a gradual slope until they drop over and come to rest on the steep sheltered side.

In a gentle wind the ripple-marks advance so slowly that one is unconscious of any change, but in stronger blasts the changes are very manifest. On a blustering March day with a keen wind from the northwest I watched some ripple-marks that were four inches apart from crest to crest, and found that they were advancing at the rate of a foot in eight and a half minutes.

The most common form of dune at Ipswich is one whose longest axis runs from east to west across the prevailing winds, and these again may be divided into two classes. Both advance to the south like waves before the boreal blasts, but the commoner, unlike the water wave, presents its erest to the storm and retreats backward. The sharp, steep side of the dune is undereut and worn away by the wind, and streams out on the sweeping slope 



\section{SAND DUNES}

to leeward. Owing to the multitude of interlacing rootstocks and rootlets of the beach grass the crest sometimes overhangs like a breaking wave, and masses of roots and sand fall from time to time as the wind undercuts them. Indeed, this slope of the dune, the reverse of the normal one about to be described, is, I believe, due entirely to these beach grass roots-bricks made with straw.

These reversed waves of sand reach their fullest development at the southern end of the Ipswich dunes, where they form a series of parallel ridges, with their steep sides facing the north. They have advanced southward in the middle more than at either end, so that they describe the arcs of circles, and resemble a series of gigantic amphitheatres. One wave that I measured in 1903 could easily be traced for some 1,350 paces, or three-quarters of a mile, and it stretched from the estuary on the inside to the sea on the outside. Its breadth varied from forty to two hundred yards, and its height from twenty to fifty feet. The distance between the waves varies from a hundred yards to a quarter or half a mile.

The highest points or peaks of the dunes 


\section{SAND DUNES AND SALT MARSHES}

often show long ridges of sand extending in the wind's axis to leeward of them, and these longitudinal dunes are sometimes found by themselves, and constitute a distinct type, although not often developed to a great size at Ipswich. They are prone to form near the beach and appear to be indicative of unusually strong winds.

Every now and then in the amphitheatre waves there are cross valleys with steep windswept walls. In the cuttings and on the sharp northward faces the stratifications in the sand are often marked, and the firmly packed layers stand out prominently, while the loosely formed ones are cut away. The strata often dip gently towards the south, for the sand is left by the wind on the southern or leeward slope, but they vary greatly and are irregularly superimposed. The angle of the northern slope of these dunes varies from thirty to ninety degrees, while that of the southern slope is about twelve degrees.

The other kind of transverse dune-the normal desert one-although rare at Ipswich, appears to form only where the wind is unhampered by the binding grass, and is one that resembles more closely a wave of the sea, 


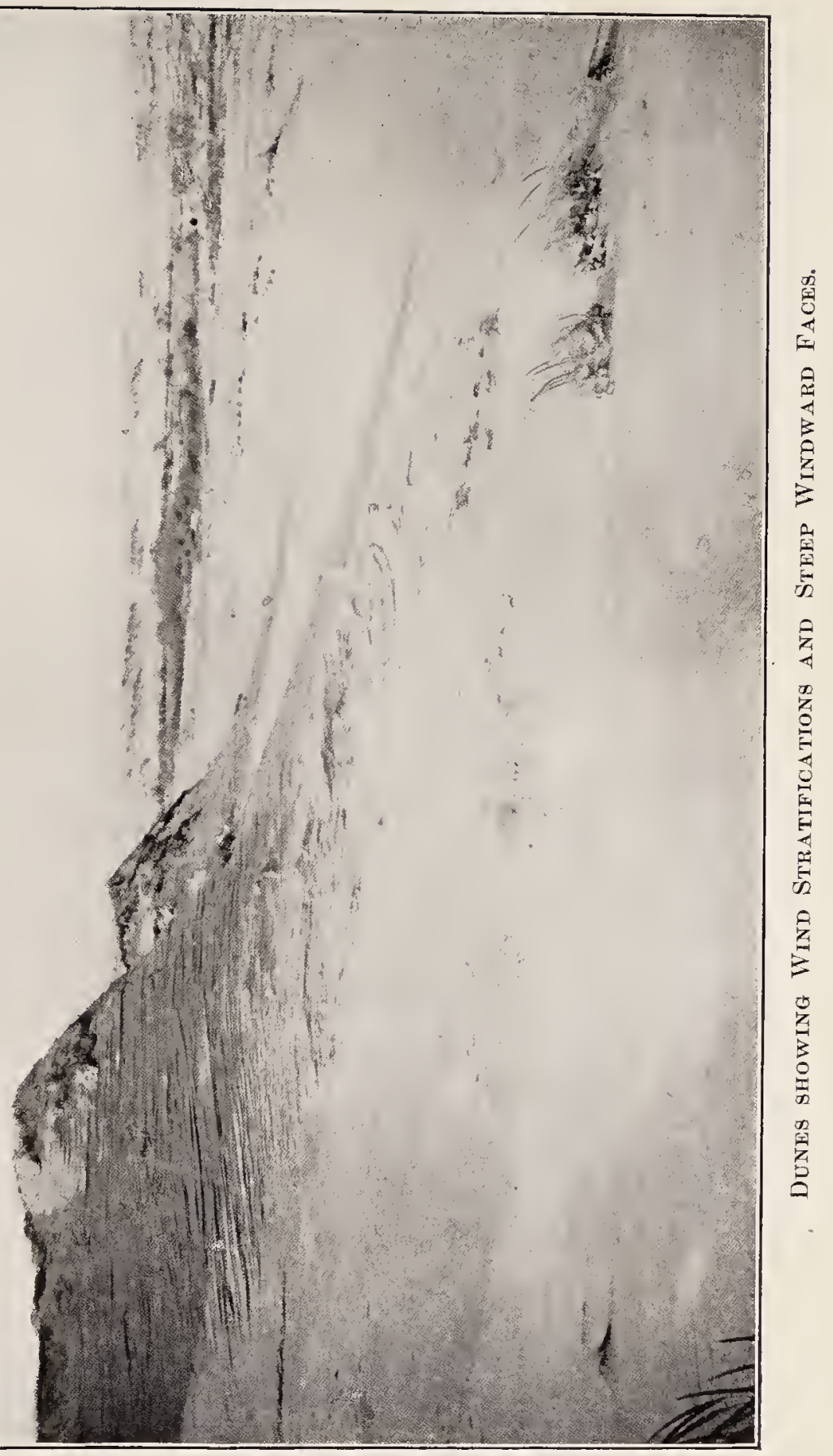





\section{SAND DUNES}

for its steep crest is borne in front, while the long, sweeping side is left behind or to windward. In these respects it is but the magnification of the ripple-marks on the surface.

There are at the present time two very striking examples of this form of dune at Ipswich, one of which, like a devastating tidal wave, is overwhelming the southernmost of the pitch-pine woods, while the other, nearer the mouth of the Essex River, is burying in its progress a grove of white birches. Both of these are unprotected on the north for a considerable distance either by bushes or by grass, and Boreas rushes over them unimpeded. The northerly slope is hard and firmly packed, and extends gently upward at an average angle of nine degrees, whereas on the south the sand, freed from the mighty power, settles softly at an angle of rest generally as steep as thirty-two degrees. Here it is so loosely compacted that one may easily sink half-way to the knees.

Both of these dunes have crests higher than their victims, the trees. The pine grove has been so far imbedded that the remains of the buried trees are beginning to reappear on the 


\section{SAND DUNES AND SALT MARSHES}

northern side of the dune. The exposed wood is decayed and soft, but masses of hard pitch can be found here and there on the bark, so thoroughly infiltrated with sand that they look like sandstone or pieces of coral.

The rate at which the dunes advance varies greatly, but it depends chiefly on the season of the year. One of the fastest dunes is undoubtedly the large one just mentioned that is breaking over the birch grove, for here at the southern end of the dunes the sand is exposed to the full sweep of the north winds, and the region is widely destitute of grass or bushes. By means of marked trees I have been able to obtain exact measurements of the progress of the dune from time to time, for the edge of the sand as it advances into the grove is sharply defined.

In the five winter months, from December 5, 1909, to May 15, 1910, the dune advanced $871 / 2$ inches, or about 17 inches a month, while in a little over five summer months, from May 15 to October 23, 1910, it advanced only 61 inches, or about 12 inches a month. The next winter was a favorable one for dune movement, for in the four and a third months, from 


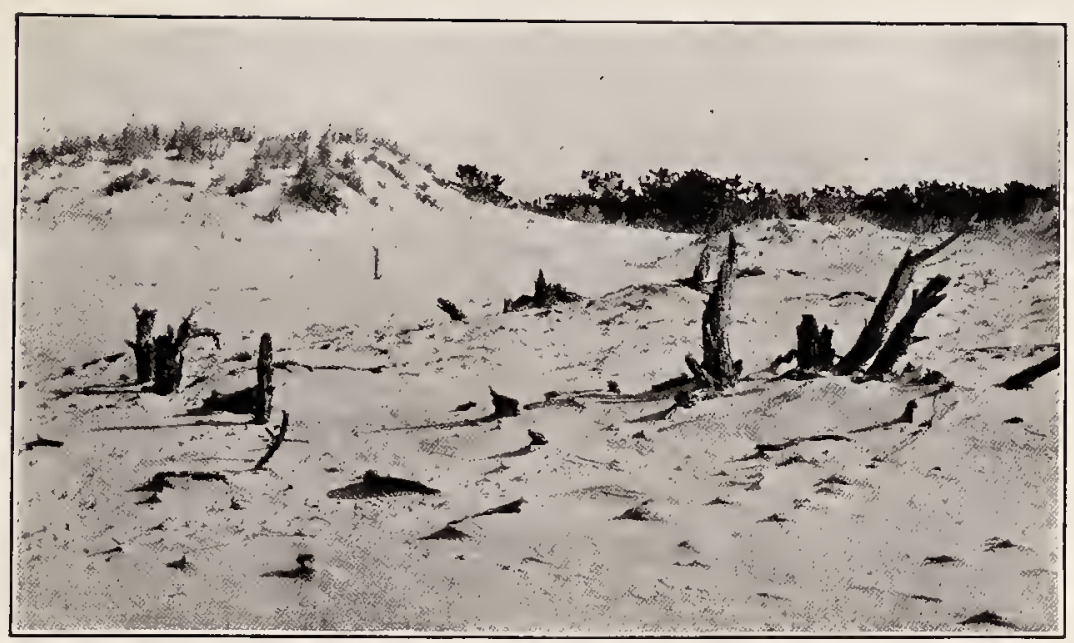

Pitcli Pines After the Dune Has Passed.

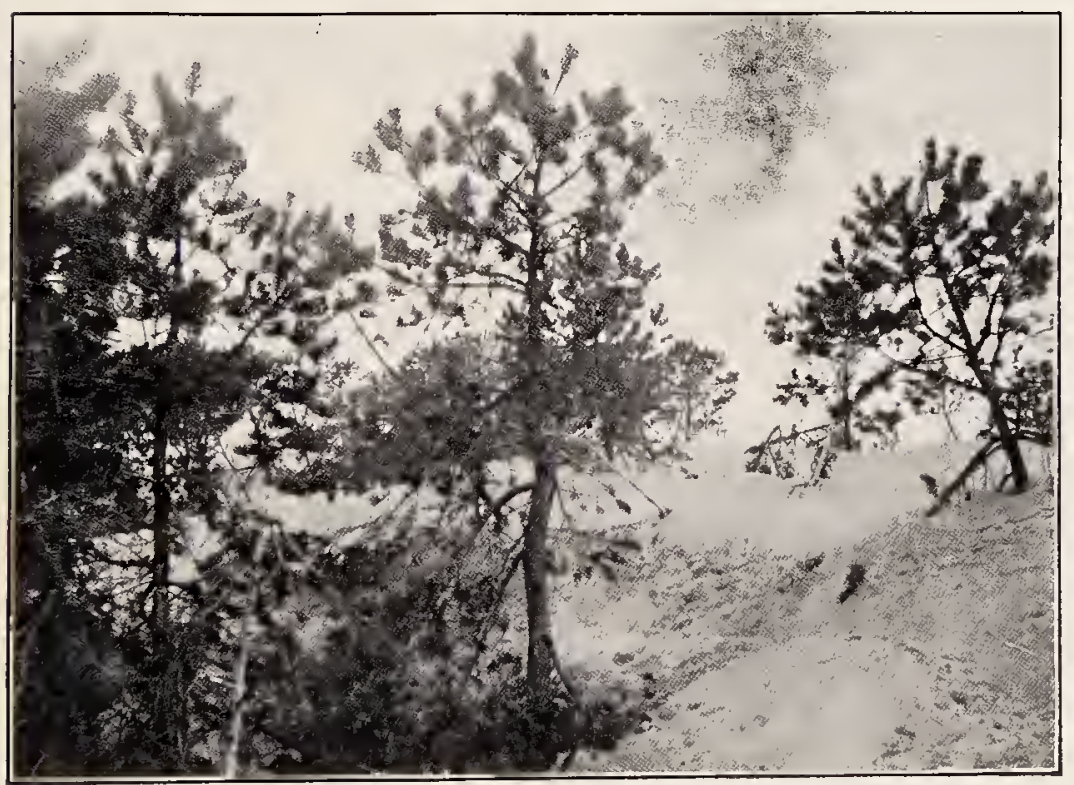

Prnes Overwheramed by the Advancreg Dune. 



\section{SAND DUNES}

October 23, 1910, to March 5, 1911, the dune advanced 256 inches, or at the rate of about 60 inches a month. The pine-grove dune advanced only 3 inches in the summer of 1910 from May 15 to November 6, but in the stormy weeks between the latter date and March 5, 1911, it advanced 71 inches.

On January 29, 1911, the signal stake placed by the Coast and Geodetic Survey on a high dune near the beach was 175 inches due south from the retreating northerly face of the dune. After four windy months, on May 28, the stake was only 132 inches from the edge, -43 inches had been cut away.

In a recent book on the Sahara, Hanns Vischer describes similar dunes, but on a much larger scale. He says: "Gradually these dunes are piled up and form ridge after ridge, some of them over four hundred feet high. These rise from the north in soft curves to fall off on the other side like a mighty wave. The ceaseless wind, mostly from the northeast, moves the sand along the surface, continually changing the position and formation of these banks." His photographs show dunes entirely devoid of binding vegetation, with camels walking on the hard windward sur- 


\section{SAND DUNES AND SALT MARSHES}

face, but sinking deeply into the steep leeward sides. The "amphitheatre" dunes so common at Ipswich, with the steep side to windward do not occur there, owing to the absence of binding vegetation.

Where the winds are irregular, as under the brow of Castle Hill, the dunes are often circular and cut out on all sides. Some have flat tops and stand out like miniature buttes, showing sections of nearly horizontal strata on all sides, while others are peaked or pyramidal in shape, and the circular scour of the winds gradually reduces their height without changing their shape.

The sand dune on the edge of the beach shown here-the frontispiece of the "Birds of Essex County" - was photographed in 1900, but by 1907 it had been entirely effaced. I always called this Eagle Dune, as I had watched a bald eagle perched on its summit, but there is a tradition that it long bore the name of "the headless sailor," for human remains of this description had been found washed up at its base many years before.

In places there are pits in the sand which are so continually scoured by the wind that 


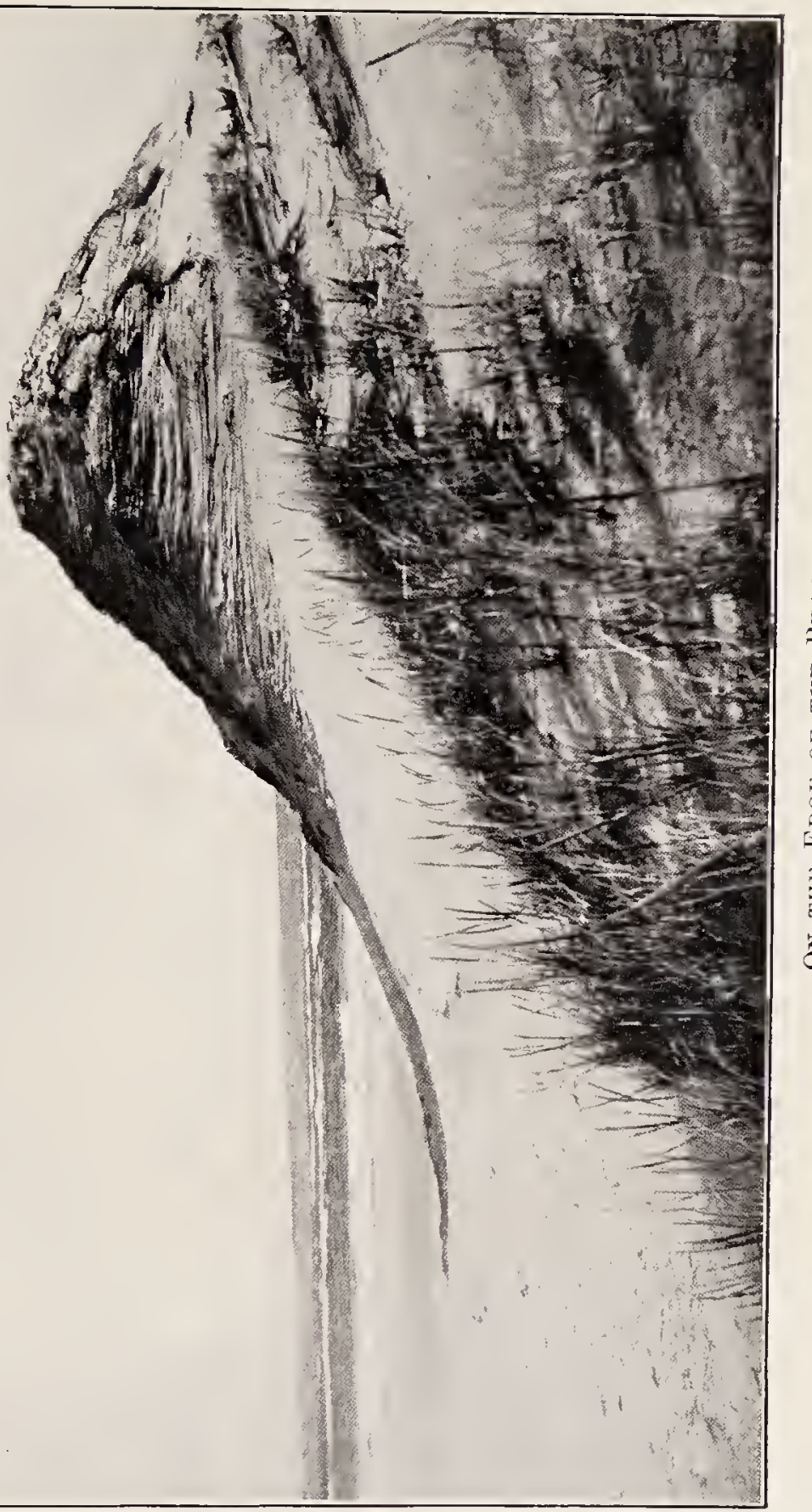

团 



\section{SAND DUNES}

they remain open, and while they fill up on the windward side, they are cleaned out on the leeward and slowly move down wind.

In a strong wind the peaks and crests of all the dunes smoke like so many chimneys, and a cloud of sand streams off, building the dune up to leeward. As Vaughan Cornish has suggested, a great mountain may be laid low by the slow process of denudation, while a humble sand dune still remains, for the process which denudes it at the same time renews it.

The sand blown from the dunes on windy days cuts with stinging force, and one must guard the binoculars, for glass is quickly ground as by a sand blast. A clouded condition of the glass is shown on exposed windowpanes in the dune camps, or on bottles or any piece of glass lying on the sand. A large flint spear-head, I found in the dunes, has been so smoothed that the sharp angles of fracture are effaced. Pieces of wood are in the same way ground down by the sand blast and take on curious shapes determined by the position of the harder knots.

The grains of sand which compose the dunes vary very much in color according to 


\section{SAND DUNES AND SALT MARSHES}

their composition, but at Ipswich the color of the dry sand is brilliant gray or white, although it may appear purple in the shadows or pink or gold in the sunset light. The winds have a selective power, and streaks and windrows of purple and garnet or even of black sands are often to be found. Under the microscope the grains appear like gems, and are seen to be more or less rounded and worn by the constant action to which they are subjected by the wind, while on the beach the majority of the grains are still somewhat angular, as if recently broken up by the pounding waves. The difference is not great, but is generally discernible. In size the sand granules of the dunes are smaller as a rule than those of the beach.

In the early spring the cranberry bogs large and small among the dunes are generally pools of water, and here, where vegetation abounds, the water is stained a brown color. Occasionally a pool may be found free from vegetation higher up in the sand, and the water appears in its true color, a greenish blue, suggestive of an alpine lake, and the snow-white peaks of sand in the vicinity serve to increase the illusion. 


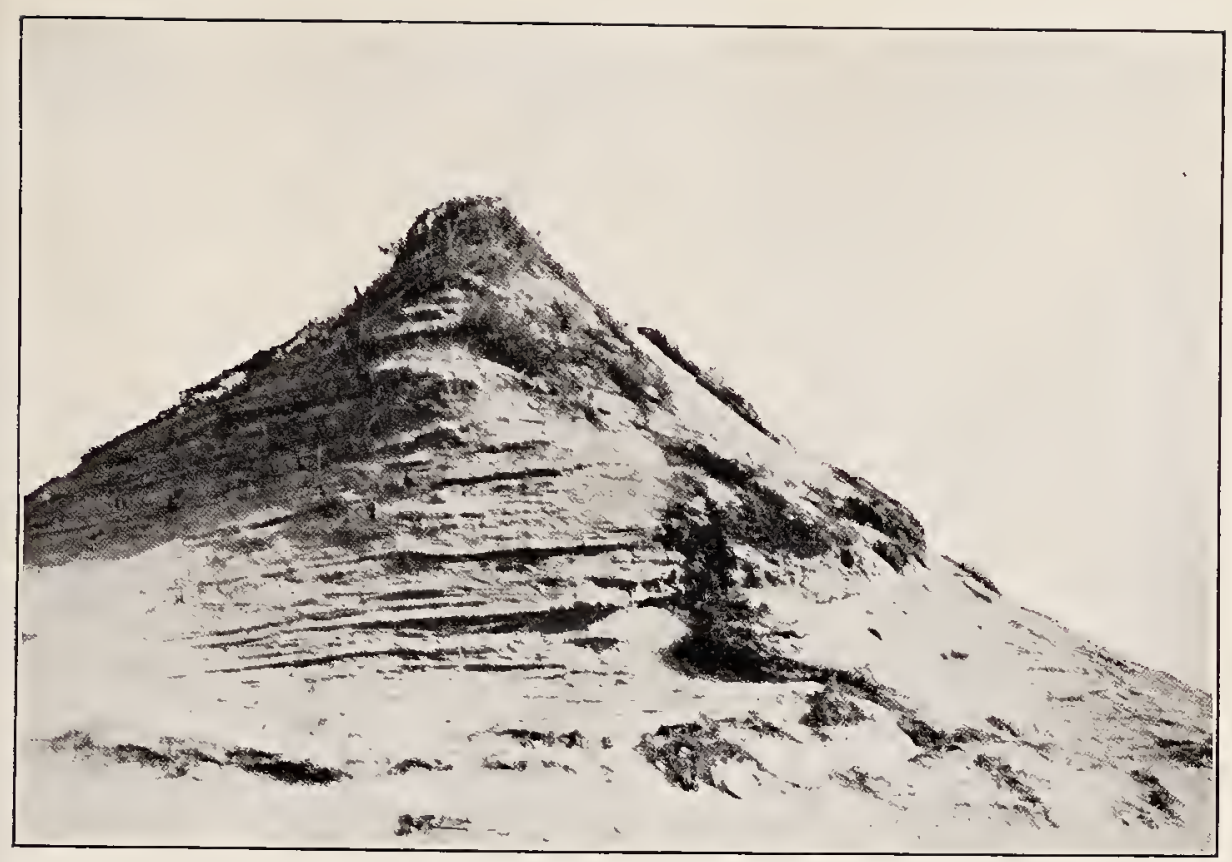

A Peaked Dune.

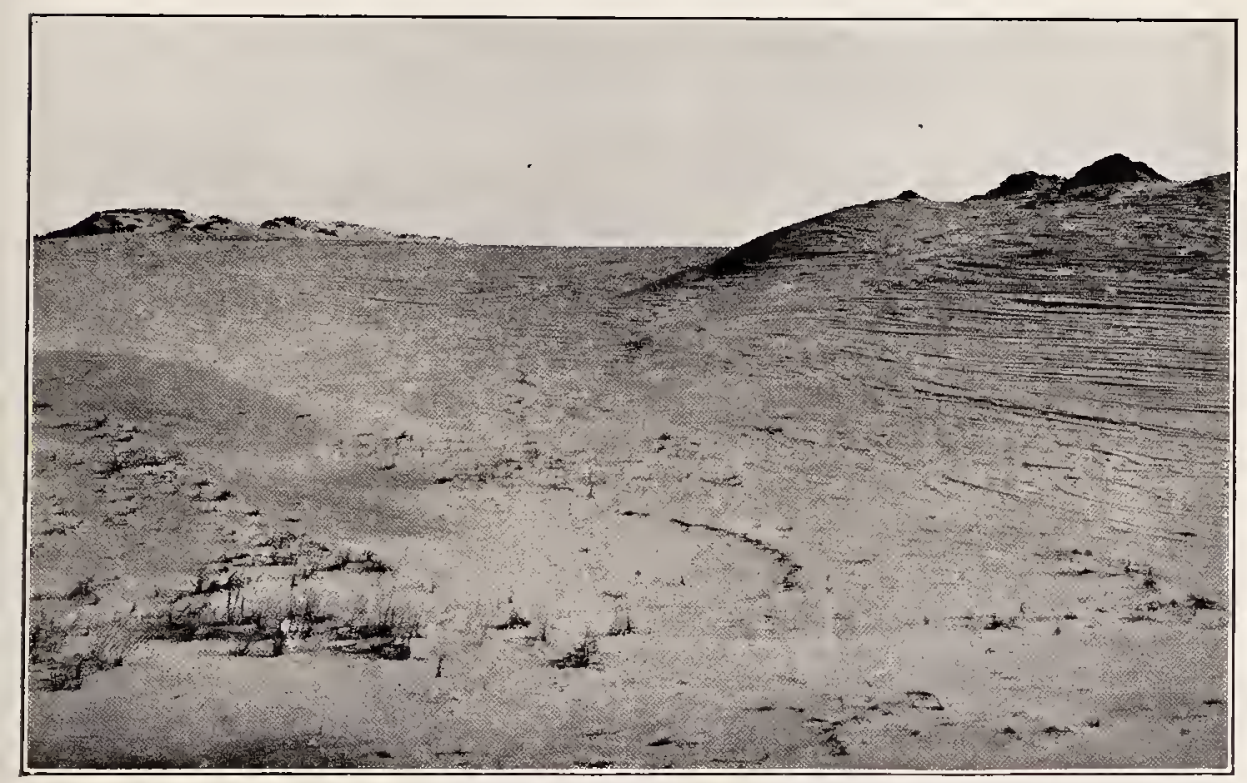

Showing Both the Steep Windward Face by Cutting, and tile Gentle Wind-swept SLope. 



\section{SAND DUNES}

Half buried in the dunes is the Ipswich lighthouse, even whiter than the sands. In 1809, James F. Lakeman sold to James Madison, the President of the United States, eighteen hundred square feet in these sandy wastes " for the purpose of erecting a beacon." In 1837, Captain Lakeman sold four acres to the United States for the erection of a lighthouse. In the deed it is stated that the northern corner of this lot was " about five rods [821/2 ft.] from water mark and beach." This same corner is now [1911] about a thousand and ninety feet from high-water mark, while the light itself is eleven hundred and forty feet from the upper edge of the beach.

The old light-keeper, Captain Ellsworth, who died in 1902, told me that when he took charge in 1861, he used to be able to talk from the lighthouse to men in boats in the water. In the line between the main light,-which slowly revolves with a long and a short flash and a period of darkness, - and the mouth of the Ipswich River is the range-light, which consists of a powerful lantern in a small wooden house. As the mouth of the Ipswich River where it enters the sea between treacherous bars is a long way to the southeast 


\section{SAND DUNES AND SALT MARSHES}

of the apparent mouth of the river and constantly shifting, the site of the rangelight has to be changed every five or six years.

In the summer of 1910 there emerged from the dunes within five hundred and forty feet of the lighthouse the timbers of an old vessel, which must have been wrecked many years before, when that spot was within the reach of the tides. Now it is six hundred feet from high-tide mark. One of the old inhabitants said he remembered the wreck, and treasured the year 1863 in his memory as the date when the catastrophe occurred. Be that as it may, the old wreck at this point serves to confirm the story of the lighthouse-keeper's conversation in bygone days with men in boats on the water.

The speedy way in which the sands swallow up wrecks was well shown by the fate of an old schooner that went ashore in the Christmas storm of 1909. The skipper had sold his farm and invested his all in the vessel, and this was his first trip for a load of sand from the perpetual supply on Plum Island. The gale swept down from the northeast thick with snow, the anchors dragged, there was not 



\section{SAND DUNES}

sea room enough to manoeuvre away from the lee shore, and he was wrecked on the beach at high tide. The poor man begged for farming work again, for there was no probability of saving his schooner, which, with every pound of the surf, settled deeper and deeper in the sand. Less than a year later she was buried to the deck.

In the seventies I used occasionally to take the long walk from Magnolia to Coffin's Beach, which lies the other side of the Essex River from Ipswich, to spend a solitary day among its strange dunes and on its long flat beach. As I lay in my blind there, intent on shooting the wandering shore birds, I often thought of the tale of Coffin's farm. When the old farmer was on his death-bed he gathered his sons about him and gave them his farm, and at the same time bade them never to eut the woods that lay between the farm and the sea. Scarcely was the old man buried than his words were forgotten by the thoughtless sons, who, instead of going farther afield for their wood, took that nearest at hand. As a result of their disobedience the winds were no longer restrained, the sand blew in and overwhelmed the fair fields, and now the tops only of a 


\section{SAND DUNES AND SALT MARSHES}

few apple trees extending above the sand show what the place once was. ${ }^{1}$

The same catastrophe has occurred at Ipswich. In the middle of the dunes on the marsh side is a long hill about sixty feet high, so covered with sand that it is generally considered a great dune. In some places, however, one can scratch the sand and find earth and gravel below; occasionally a boulder projects, and here and there one comes on ancient stone walls, some of which have been uncovered by the blowing sand within a few years. In 1892 there was an orchard near the top and on the southwesterly slope, somewhat less than an acre in extent. Part of this orchard was still nearly unscathed by the advancing sand, which had merely dusted the ground, but the rest was buried to the tops of the main trunks, and all the horizontal and drooping limbs were covered, yet the topmost branches blossomed and bore fruit. But the sand encroached more and more, and one after another the strangled trees gave up the ghost,

${ }^{1}$ In Babson's History of Gloucester, published in 1860, it is stated that Peter Coffin, after failing at law and business, "went onto the farm, where he lived as long as it would yield him a support by the sale of the wood upon it, and then came back to town, and died Aug. 4, 1821, aged seventy-two." 



\section{SAND DUNES}

and the tops only of dead branches stretched above the sand. The struggle was a hard one, and for many year's some of the braver tree-tops blossomed with cheerful promise in the waste of sand, but came to no fulfilment of fruit. In 1910 all I could find to mark the place were a few wind-and sand-beaten applebranches. The orchard was entirely buried in the white sand!

The seaward side of this drumlin, for drumlin it is, on which the old Lakeman farm once flourished, is in places a precipitous gravel cliff more or less whitened with sand. This cliff shows as surely as if it had stated the fact in words, that at one time waves of water, not of sand as at present, beat against its foot. The distance from the foot of this ancient seacliff to the sea, now filled in by sand dunes, is about twenty-four hundred feet. We have just seen that a vessel that went ashore near the lighthouse is now, after the lapse of about fifty years, some six hundred feet from the upper edge of the beach, so we might calculate that the sea beat at the foot of this gravel cliff about two hundred years ago. This, however, is not a safe estimate, and may be wide of the truth, for the beach and dunes are con- 


\section{SAND DUNES AND SALT MARSHES}

tinually changing with changing sets of tide and currents, and while one part is building out another part may be washing away.

Yet this estimate just given is confirmed by an ancient manuscript map, now in the possession of Mr. R. T. Crane, Jr., to whom I am indebted for a photographic reproduction given here. This is entitled "A Representation of Castle Hill \& Castle Neck with ye adjacent Sea, Rivers Creeks Hills Islands and Marshes, Protracted from a scale of forty rods to an Inch. P. B. Dodge Ipswich April 3 1786." The old Lakeman farm was then inhabited by grandfather Choate, and the hill we have just been considering is called "Wigwom Hill." The foot of the hill is distant from the sea, according to the map, some eighty rods, or thirteen hundred and twenty feet. As the sea is now twenty-four hundred feet off, the dunes have gained eleven hundred feet in one hundred and twenty-four years. This corresponds fairly closely with the approximation of six hundred feet in fifty years obtained from the old wreck.

The southeastern end of the dunes do not extend beyond Hog Island in this map, and the distance from the farmhouse of Wigwam 30 



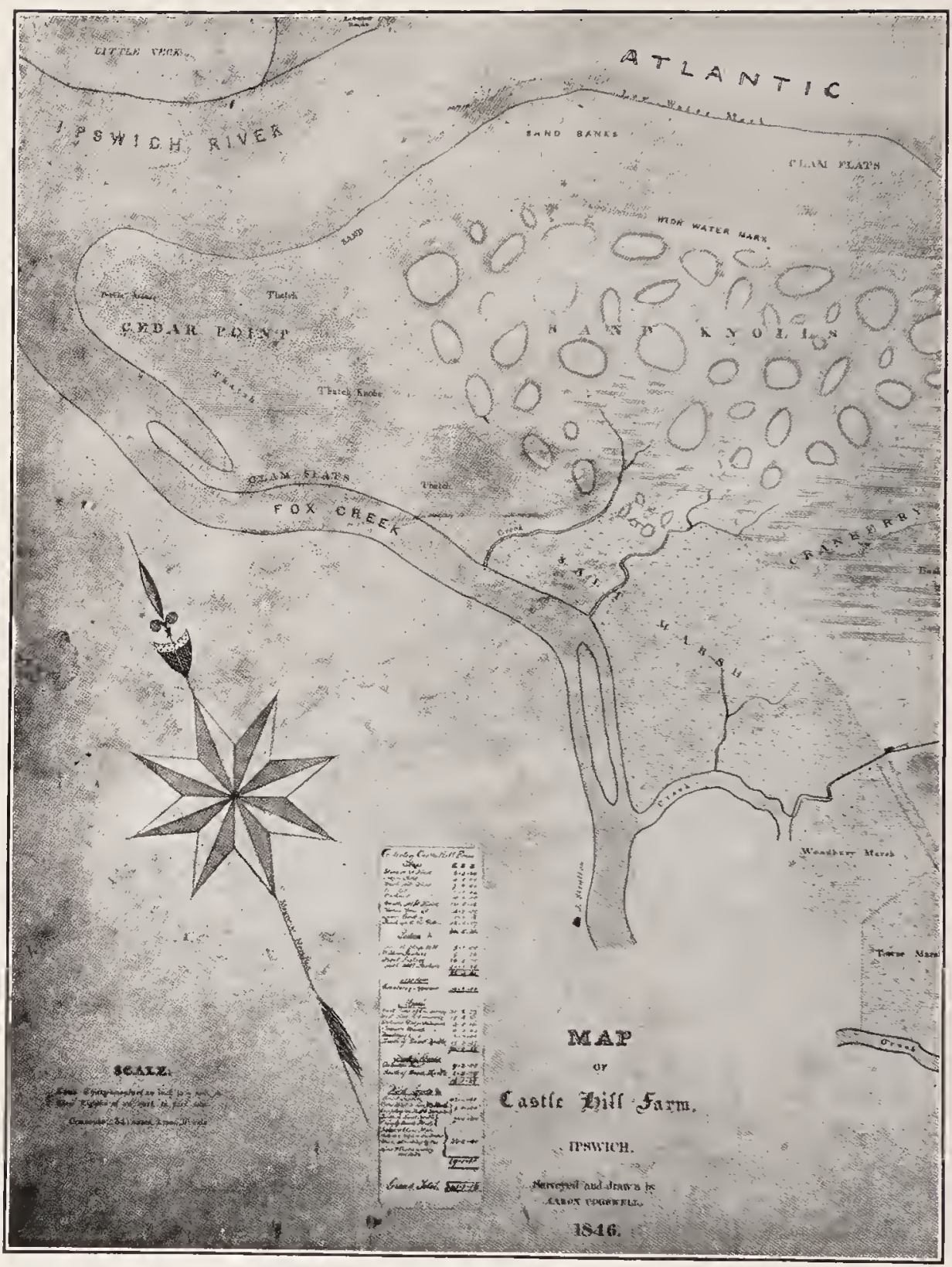

MaP OF 


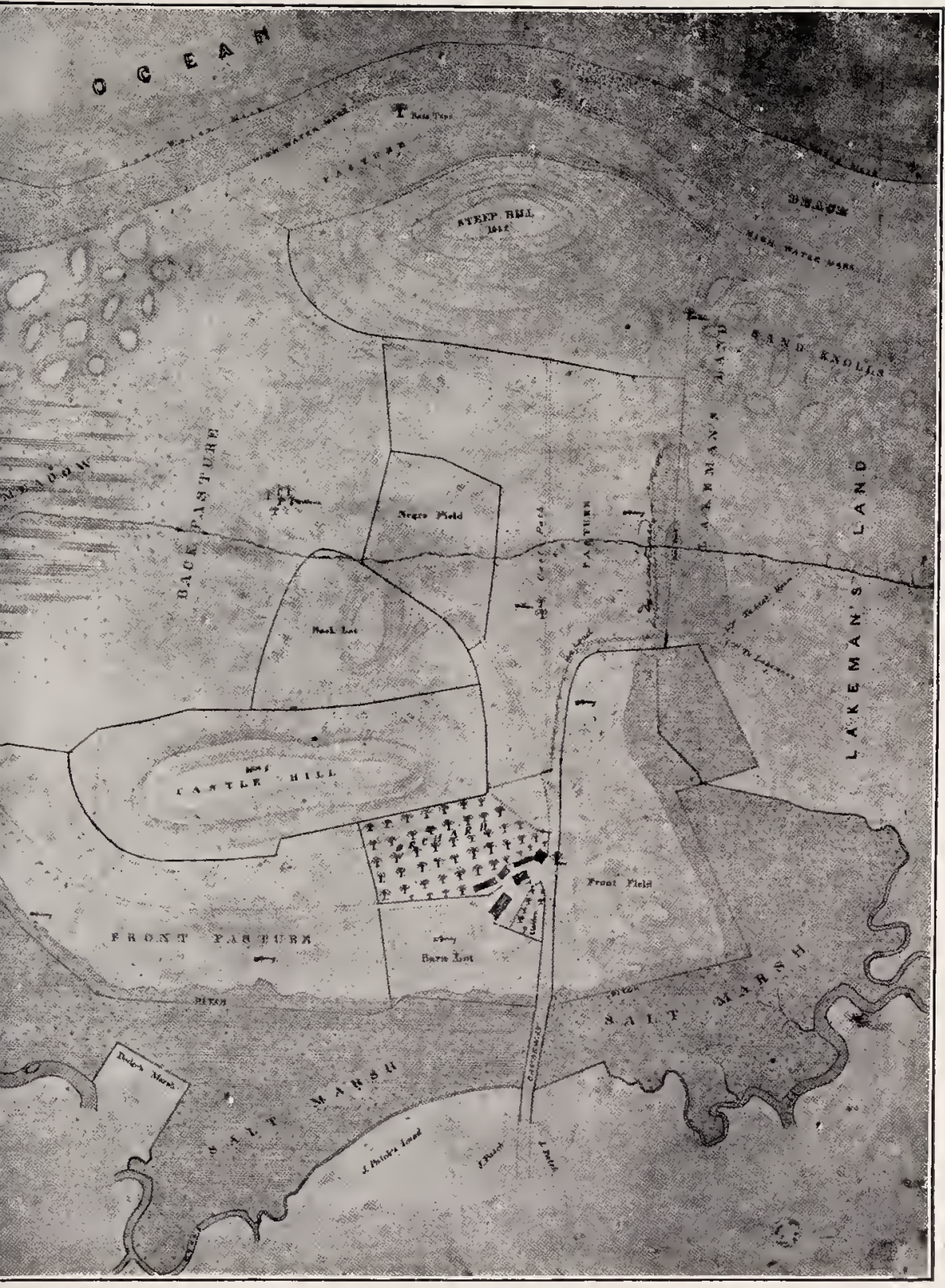

Castle Hilla Farm, 1846. 



\section{SAND DUNES}

Hill to the end is about a mile. At the present day the distance is fully two and a half miles. I do not feel sure, however, of the accuracy of the scale of this map, although I may do the author an injustice. There are some other points shown by the map which, however, do not depend on scale, and are interesting as showing the changes that have taken place. One of these is the indication of trees or woods at the inner end of the point of the dunes, where no woods exist now; another is the "New Channel" between the end of Plum Island and Ipswich " Barr," which is now entirely obliterated; and the third is the extension seaward of Steep Mill, the northeastern peak of Castle Hill. This latter point is more clearly shown on the map of 1846 made by Aaron Cogswell. Here the contour line shows a gradual sloping of Steep Hill to the beach with a field labelled "pasture" between, in which is a "Bass Tree." The distance from the highest point on the hill to tide mark is about five hundred and twenty feet. At the present time the pasture and the bass tree are obliterated, while the northerly slope of the hill has become a cliff whose crest is on a level with the top of the hill; the tides wash its 


\section{SAND DUNES AND SALT MARSHES}

base. Thus it were better to build one's house on the shifting sand which grows and endures than on the rocky hills that sink into the sea.

In winter among the dunes the snow and sand are drifted mingled together or separately, and one often finds a deep white snowbank beneath a skimming of sand, which, if the snow is melting, is darker than the surrounding dry sand. Other signs of buried snow are the deep fissures formed in the sand by the contracting snowbanks, and the crunching sound that issues when one walks over the concealed snow. One of the largest snowbanks, which became almost a glacier, I watched during the severe winter of 1903-4. This was an immense drift of snow and sand, separate and commingled, encroaching on the north side of the grove of pitch pines. A layer of sand from one to two feet in thickness, which reflected but did not so easily conduct the sun's rays, so protected the snow that it became compact and crystalline. On May 15th, this crystalline snow had a thickness of thirty-eight inches at its exposed face, under which, extending back to a distance of three feet, was a "glacial " cavern. The sand on top was cracked and crevassed, and this, 


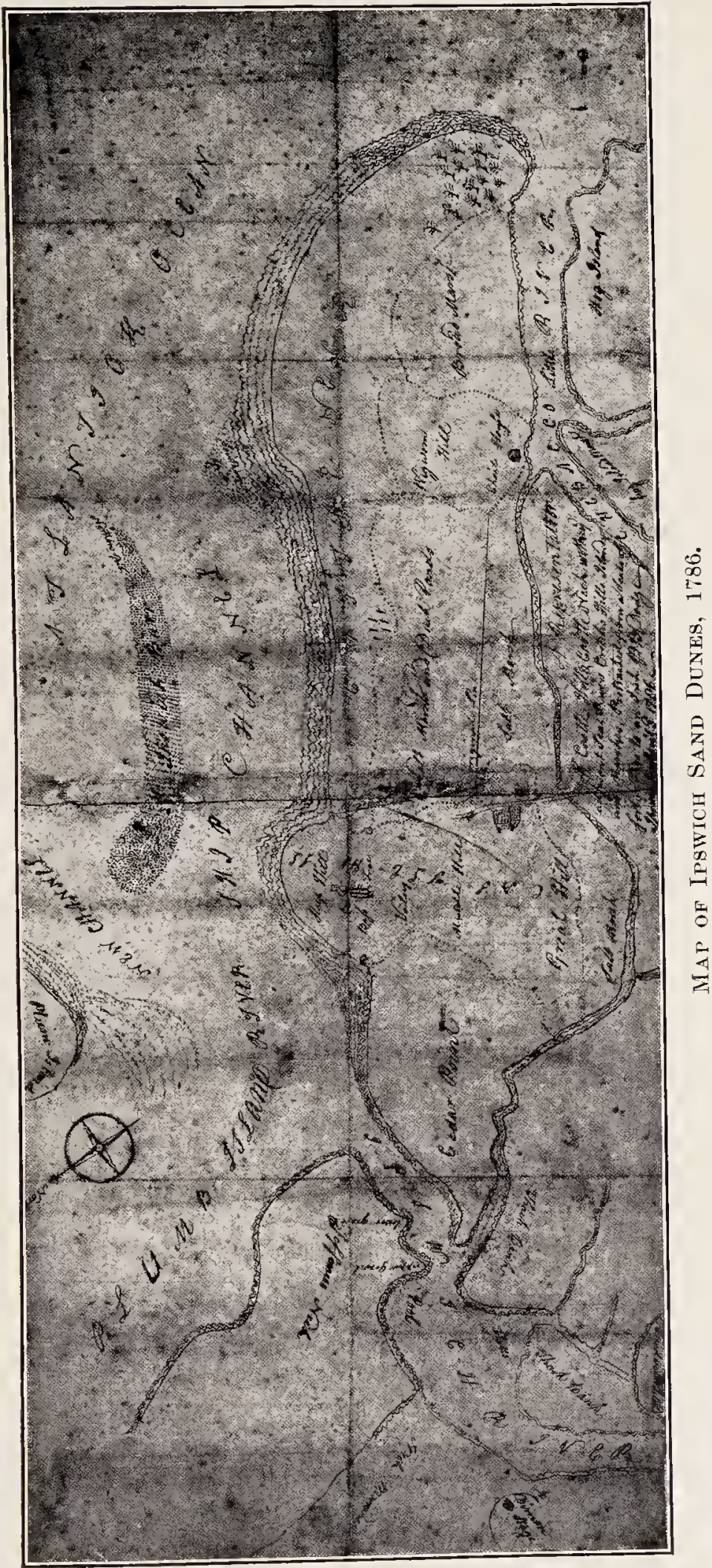





\section{SAND DUNES}

together with the bending of the trees, suggested the possibility of some motion down the slope. On May 30th, the face of the " glacier " was covered with sand, but marks made on a tree showed that the drift had sunk fortytwo inches since May 8th. A week later, on June 6th, I dug for the glacier but could not find it.

While these snowbanks in the dunes are suggestive of alpine glaciers, the ice formations on the beach and ocean are suggestive of the polar seas. Both are miniatures of the real thing. During severe frosts an ice cliff forms at the upper edge of the beach, and this presents to the advancing tide a sea-wall from two to eight feet high. Against this the waves beat, and the spray flung up on the top freezes and adds to the height. While the top is fairly smooth, except where it is eaten away by the waves that have broken through it, the sea façade is hollowed into caverns or built out in parapets and festooned here and there with icicles.

Although the beach itself, uncovered by the tide, is generally free from ice, it is occasionally glazed over and strewn with great cakes that in zero weather extend out over the water 


\section{SAND DUNES AND SALT MARSHES}

to form in places a solid shelf,-an " ice-foot." But in most places, during weather like this the ocean is beset with floating cakes of ice, and with newly forming ice which in the heaving and churning of the sea appears like grains of sago, and later takes the form of small rounded or many-sided cakes with raised edges, the " slob-ice" of the Labrador coast, the "pancake ice" of Scorseby. Everywhere beyond the ice and in the open leads the sea seems to boil and great clouds of mist roll upward, for the warmer water of the sea actually steams in this aretic weather, and the distant view is obscured. Here are patches and lanes of black water, there, bands of solid floe brilliantly white in the sunlight. Icebergs, the most magnificent arctic phenomena, once seen, always to be treasured in the memory, do not appear on this coast. It is far too distant from the parent glaciers.

On one occasion, in February, when the thermometer was six degrees below zero, and the water was covered with pancake ice, I heard in the still air a sighing, whistling note, an aeolian-harp-like sound, which appeared to have its source in the heaving, churning ice-cakes. 


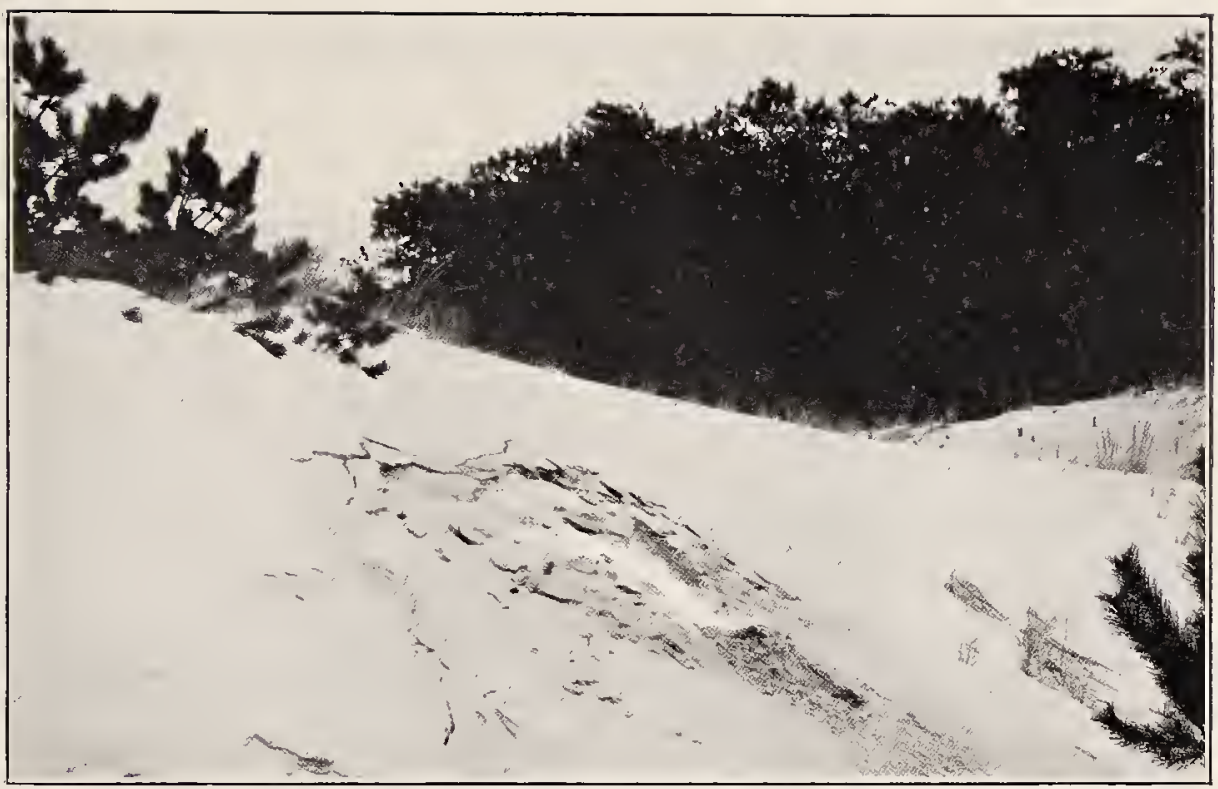

"Glacier Dune," Showing The Cracked Sand and the UNDERIYING SNOW.

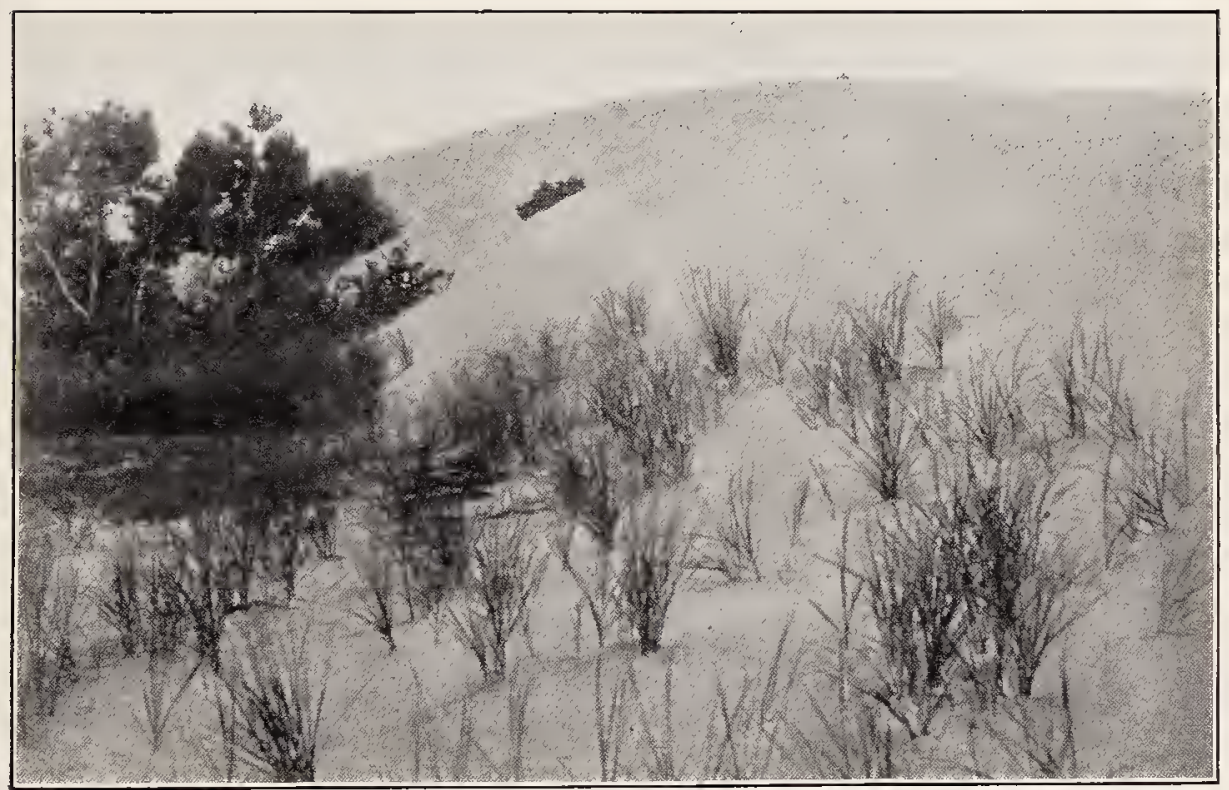

Dune Overwhelming Birch Grove, SHowing tue Steep LEEWARD SIDE. 



\section{SAND DUNES}

Another interesting phenomenon of arctic weather is the geyser-like bubbling occasionally seen along the beach at high tide in two or three feet of water. For minutes at a time geysers a foot in diameter belch forth great streams of air which throw the water up in miniature fountains. The explanation of this seems rather obscure, but I have thought that a sudden severe frost at the time of the ebb had sealed the surface of the sand, and the water, escaping beneath, had left numerous interstices into which the air permeated, to escape when the warm water of the rising tide melted the ice seal and forced out the air. Possibly the presence of dead thatch grass, thrown up and buried in the sand, aided in the accumulation of air. This phenomenon is very different from the tiny air spouts that arise from the burrows of beach fleas.

As one walks along the edge of the dunes near the beach in summer or winter, his attention may be attracted by a number of balls which appear to be made up of broken pieces of straw or grass. Some of these are not larger than a tennis ball, others the size of a cocoanut; some are perfectly spherical and firmly matted, others are loosely formed and 


\section{SAND DUNES AND SALT MARSHES}

often elongated in shape. Similar grass balls were found by Thoreau on the shores of Flint's Pond in Lincoln, and they appear to have puzzled him considerably. It is evident from a careful study of a series of these balls and by actually watching their formation, that they are gradually built up in shallow water near the shore by the rolling action of the waves on particles of broken thatch, sticks, seaweed and grass which have collected in hollows and ripple-marks. A nucleus once started, more and more material is added as the ball rolls about.

These balls are to be distinguished from the hair balls, also occasionally found on the beach, that are formed in the stomachs of cattle, as well as from the balls formed by the rolling about of pieces of submerged marsh sod, which often take on a rounded pebble shape.

Hail to thee, O wondrous Sand Dunes!

Faithful guardian of the marshes,

Ever waxing, ever waning,

Heaving like the waves of ocean.

We have braved thy storms in winter,

We have breathed thy heat in summer, 


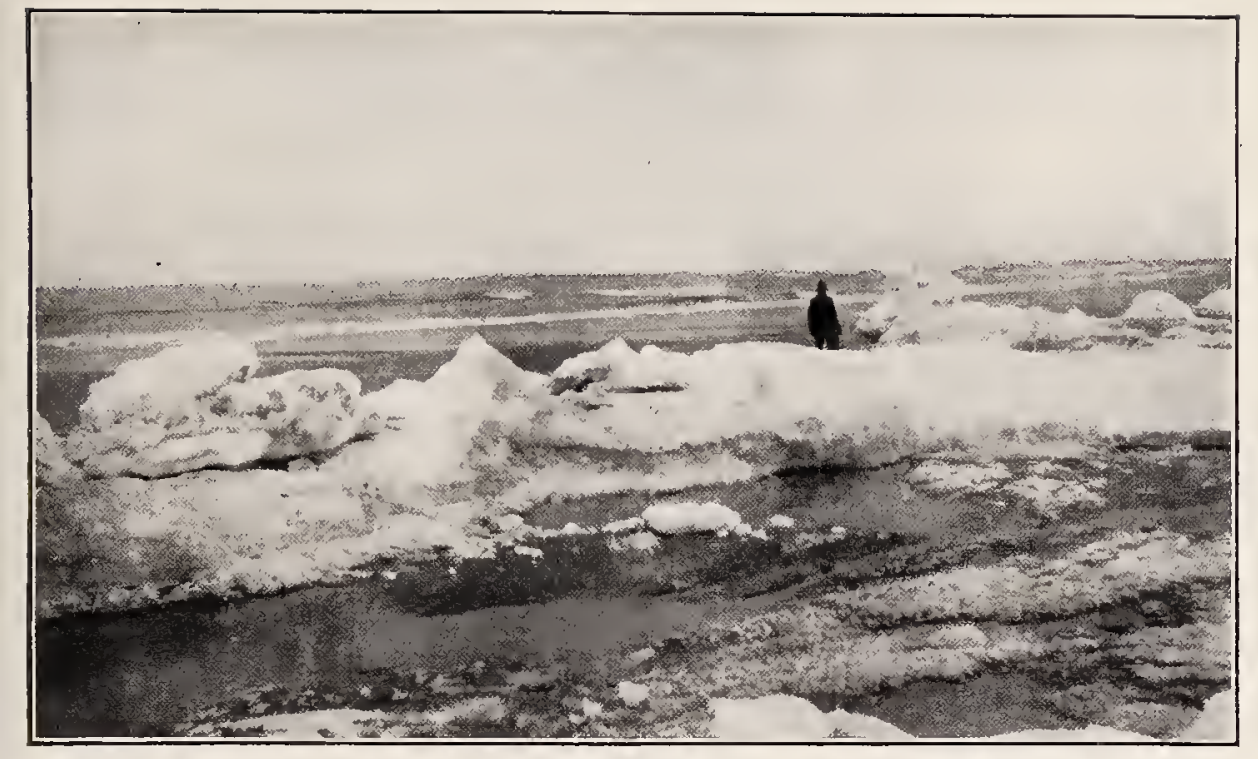

ICE WALL.

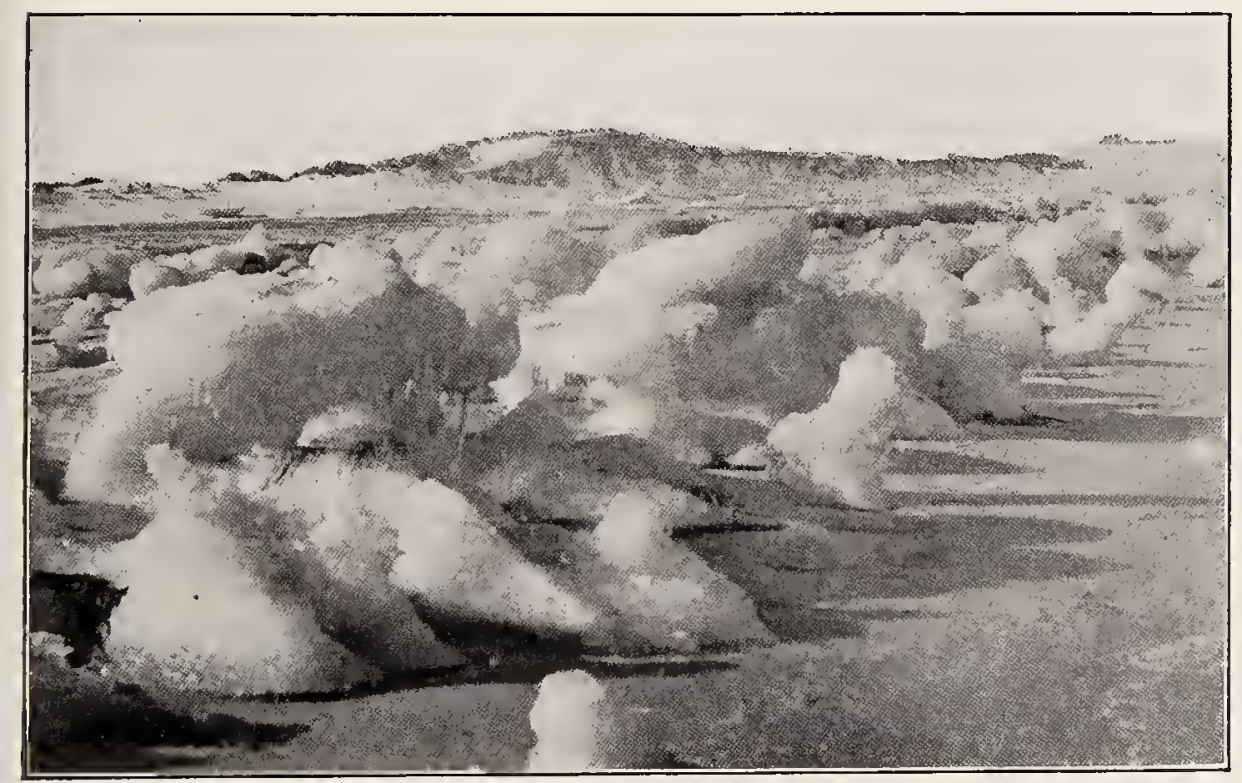

ICE IVALL. 



\section{SAND DUNES}

We have slept upon thy bosom, Smelt the perfume of thy flowers, Tracked thy mice and deer and foxes, Heard the screaming of thy sea gulls, Watched thy birds from out the Northland, Loved thy beauty ever changing.

May we gain from thee, O Sand Dunes! Strength and health and steadfast purpose, Length of days and joy in living, Mighty Sand Dunes born of ocean! 


\section{CHAPTER П}

\section{TRACKS AND TRACKING}

"Unto each the spoor and sign."

- Kipling.

O $\mathrm{N}$ the snow the study of the tracks of birds and beasts is an interesting one, although often of short duration, limited to the winter and to favorable snowfalls; but at all seasons, in the white fields of sand he who runs may read the history of the dune inhabitants. In the exposed places the wind may speedily efface the records, or the frosts of winter may render parts of the surface unyielding to the impress of feet, but there are always places in the dunes where the tracks are wonderfully perfect. In the summer, creatures that never are seen in the winter, and consequently never make tracks in the snow, such as toads, snakes and grasshoppers, spread their strange hieroglyphs over the sand. 



\section{TRACKS AND TRACKING}

The most favorable time for the study of tracks is in the early morning when the oblique sunlight makes deep shadows, when the morning dew moistens the surface so that it retains best the shape of the imprints, and before the wind has arisen to obscure them with the blowing sand.

The dune lover comes to recognize the common tracks as quickly as he does the face of an old friend, and the study of the new and less familiar ones is always enticing. Not only can one learn the nature of the animal that makes the tracks, but often a good deal about its manner of life. In the case of most of the makers of tracks, with the exception of birds and insects, the creature is rarely or never seen, and all the insight we can get into its life is from the telltale footprints and perhaps from its droppings. This is the case very largely with the mammals, for most of them are nocturnal in their habits, lying concealed during the hours of daylight when their deadly enemy, man, stalks abroad.

One of these night walkers is the Virginia or white-tailed deer, that charming animal which, thanks to the well-enforced protective laws, is more abundant in densely settled east- 


\section{SAND DUNES AND SALT MARSHES}

ern Massachusetts to-day than it has been for over a hundred years, and it is possible that in some localities it is even more abundant than has ever been the case. At first thought this seems a rash statement and an unreasonable conjecture, but it is within the bounds of possibility, for not only has white man ceased to persecute the deer, but he has eliminated its natural enemies, such as wolves, lynxes and panthers, as well as the Indians. Thoreau wrote in 1853: "Minot says his mother told him she had seen a deer come down the hill behind the house and cross the road and meadow in front. Thinks it may have been eighty years ago," - that is about 1770. I was told that half a dozen deer were recently seen in one field in Concord, and single deer are almost every-day occurrences.

Since about the year 1900 deer have been appearing in increasing numbers in this seashore region, but not until 1906 did I have indubitable evidence of their presence in the dunes. In May of that year I found the tracks of two deer in the sand, but, although I occasionally saw deer in the daytime elsewhere, it was not until 1910, owing largely to their nocturnal habits, that I actually saw the ani- 


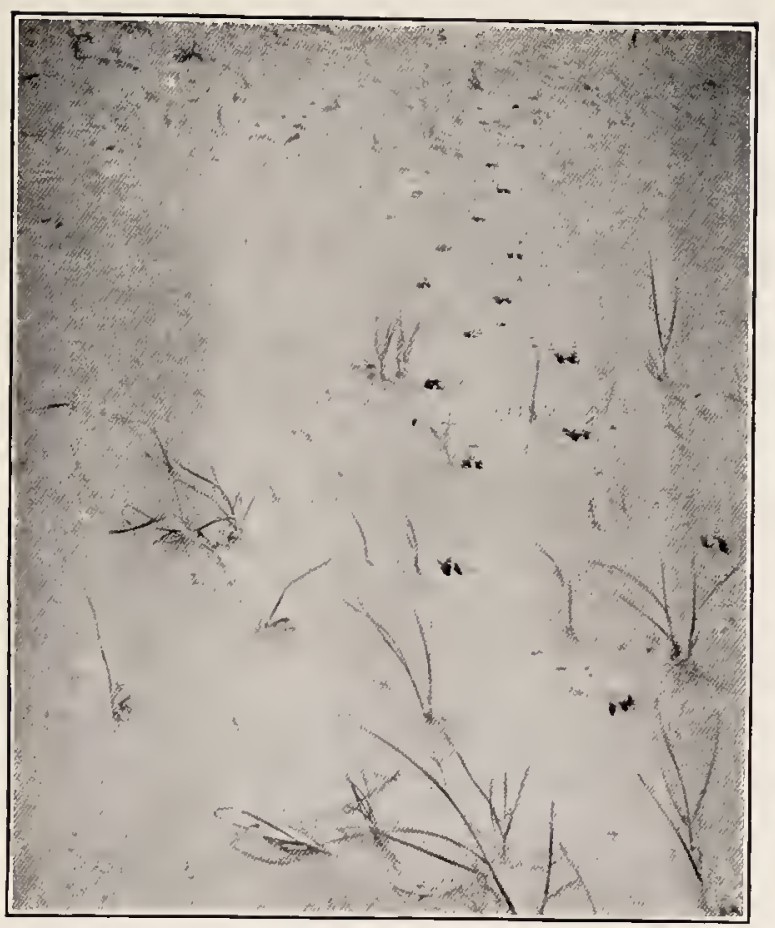

Deer Tracks.

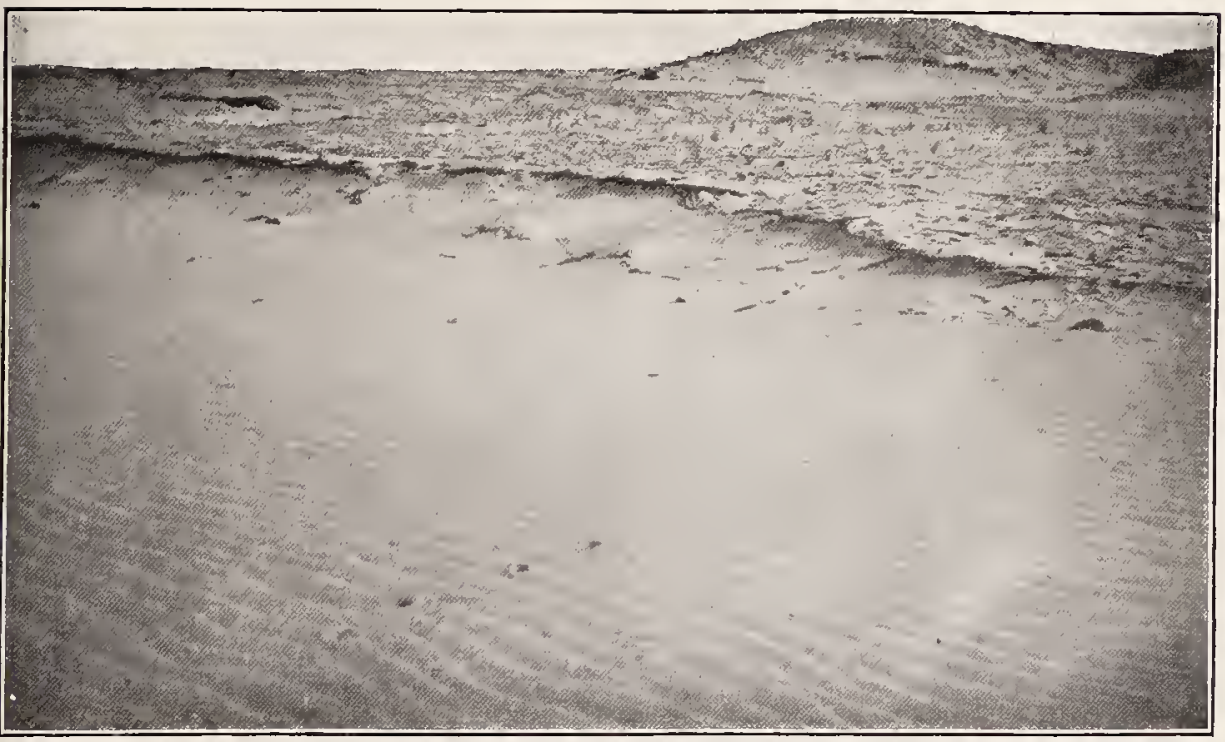

JACK RABBIT TraCks, IPswich, 1903. 



\section{TRACKS AND TRACKING}

mals in the dunes. I have no doubt, however, that I have frequently passed close to them in the sunlight as they lay crouched in the dune thickets. Their presence has not been an entirely unmixed pleasure to all, for the lone farmer of the dunes, whose arable land and orchards were first covered by the sand, and whose planted peas were later scratched up by the imported pheasant, has recently been obliged to erect high wire fences around his small, sandy vegetable gardens to prevent their total consumption by the deer. Near the farmhouse on Castle Hill are some Japanese yew trees which prove in winter a most attractive diet for the deer. To protect these, scarecrows of red flannel wave their flimsy arms in the breeze, and I have recently been obliged to protect in a similar manner some of my own white cedars to prevent their total destruction. However, the occasional sight of these graceful animals, and the more frequent discovery of their delicate tracks, is well worth while.

I shall never forget a splendid buck with spreading antlers that trotted over the broad marshes one beautiful summer morning in full view of my house. Into the tide he 


\section{SAND DUNES AND SALT MARSHES}

plunged, and swam until he came within sight of some boats at their moorings. Turning in alarm he regained the bank and by leaps and bounds disappeared over the marsh in the direction of a wooded island. The Virginia deer takes to salt water as to the manor born. On a bleak March day in 1909 I landed with Ralph Hoffmann and Glover Allen on Milk Island, a good half-mile off the end of Cape Ann, to watch at closer range a snowy owl. The owl flew to the mainland, but to our surprise a lovely doe began bounding over the low bushes, throwing up her white flag of a tail in a manner that seemed to light up the whole islet. It is impossible to accept Abbott Thayer's ingenious theory - which only an artist could have invented-that the white tail against the sky in the night-time so cuts up the outline of the animal that the wolf, stealing up for the fatal leap, is confused at the crucial moment and the "obliterated" deer escapes. A stuffed deer, skilfully disposed by the enthusiastic artist, seems to prove this theory so forcibly that some are led to accept it, forgetting the wonderful sense of smell on the part of the wolf, which must be so overwhelming at such close range, that, 


\section{TRACKS AND TRACKING}

even blinded, he would leap true. The strongest argument against such a fantastic theory, however, is that in the daytime, as well as in many situations at night, when the trees or hillsides cut out the sky, the flashing tail does not obliterate, but renders much more conspicuous its owner, even to the crouching foe. I once saw two deer at dusk in a meadow surrounded by woods. The light was so poor that I could hardly distinguish the creatures until in alarm they raised their white tails. Even when I assumed the position of the " crouching wolf," the white tails were most conspicuous and advertised the deer. It was impossible to bring the tails against the sky. If there were not some other reason for this flashing tail it would on account of its conspicuousness long ago have been itself obliterated by natural selection. There are many facts in nature that are difficult to understand, and it is far better to admit ignorance than to accept an untenable theory. In the case of this deer, however, as in the case of other creatures similarly marked, the theory that the white spot is intended to be conspicuous and to be used as a directive mark or as a danger-signal to others of the same species 


\section{SAND DUNES AND SALT MARSHES}

seems a common-sense view, and will answer for most naturalists as a good working hypothesis.

Early one May morning, while the sun was still low over the sea, I was walking up wind along the beach, when I noticed a doe standing like a statue with ears erect, gazing out into the east, a worshipper of the two greatest mysteries, the sea and the sun. Although I stopped and myself stood motionless, the nervous twitching of her tail from side to side showed she was uncertain as to the identity of the object on the beach, but when she turned and ambled off into the dunes her tail remained down, the flag did not show, and I concluded from the absence of this instinctive danger-signal of her race, that she had not recognized me and was not alarmed.

One January day in 1912 I had been watching a herd of twenty seals on the bar, and many sea birds in the water, when I looked towards Steep Hill and saw, standing in the snow and against the sky line, a group of seven deer-two stags and five does or fullgrown fawns. The stags, with heads erect and splendid spreading antlers borne on high, stood like statues peering at what they sus44 


\section{TRACKS AND TRACKING}

pected was evil but did not know, for the wind was not in their favor. The does with feminine curiosity stretched their slender necks in my direction and erected their great ears. The group formed a picture long to be remembered. Finally one stag, more knowing than the rest, raised his white flag, spread the long white hairs on his rump, and ambled off, and the others at once followed suit.

Deer tracks in the dunes are often abundant and easily recognized. Usually the marks of the split hoofs only are seen, but in the softer sand the imprints of the two additional dew-claws show. When the animal trots the hind feet are placed so exactly in the marks of the front, that one rarely sees the double imprint, but when the deer bounds away in fright or play, all four feet strike the ground separately. One such set of bounding prints I measured and found that each jump was four feet long. One can almost see the graceful animals as one follows the clean-cut tracks, sometimes of a great bounding stag, sometimes of a doe with a little fawn. Usually these two trot along together, but sometimes the fawn springs about in small circles near its sedate mother. 


\section{SAND DUNES AND SALT MARSHES}

When the prairie-hare or western jack-rabbit was introduced in Ipswich I do not know, but throughout the nineties and up to about the year 1907 it was common in the dunes, and its tracks were everywhere. In the last named year it began to diminish in numbers, and in 1909 it was no longer to be found in its old haunts, and to-day is, I am afraid, entirely extirpated. Whether this extirpation was due to the foreign and unfavorable environment, or to the fox, which has increased considerably in numbers since 1907, is an open question, although the jack-rabbit ought to be able to escape the fox in a fair race. Seton calls it " the speediest wild four-foot left on the Manitoban prairie to-day," and says it can outrun the fox. The fox, however, does not restrict himself to fair means and the open chase in obtaining his prey, neither does he decline the fat and tender young.

When jack-rabbits were common, I could almost always in a day's walk start one, and I never ceased to be astonished by the creature that looked almost as large as a calf, as it bounded off through the dunes.

Both Coues and Seton describe this starting up and bounding away of the jack-rabbit so 46 


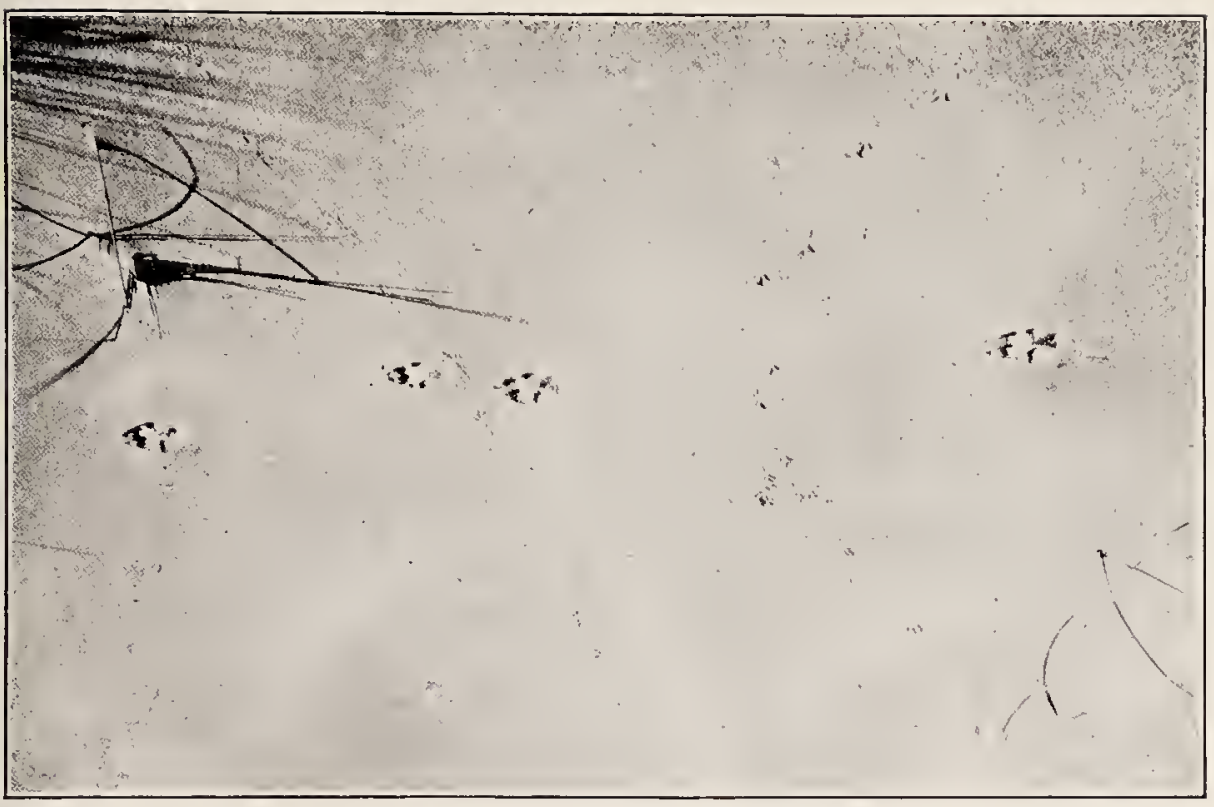

Tracks of Fox and Crows.

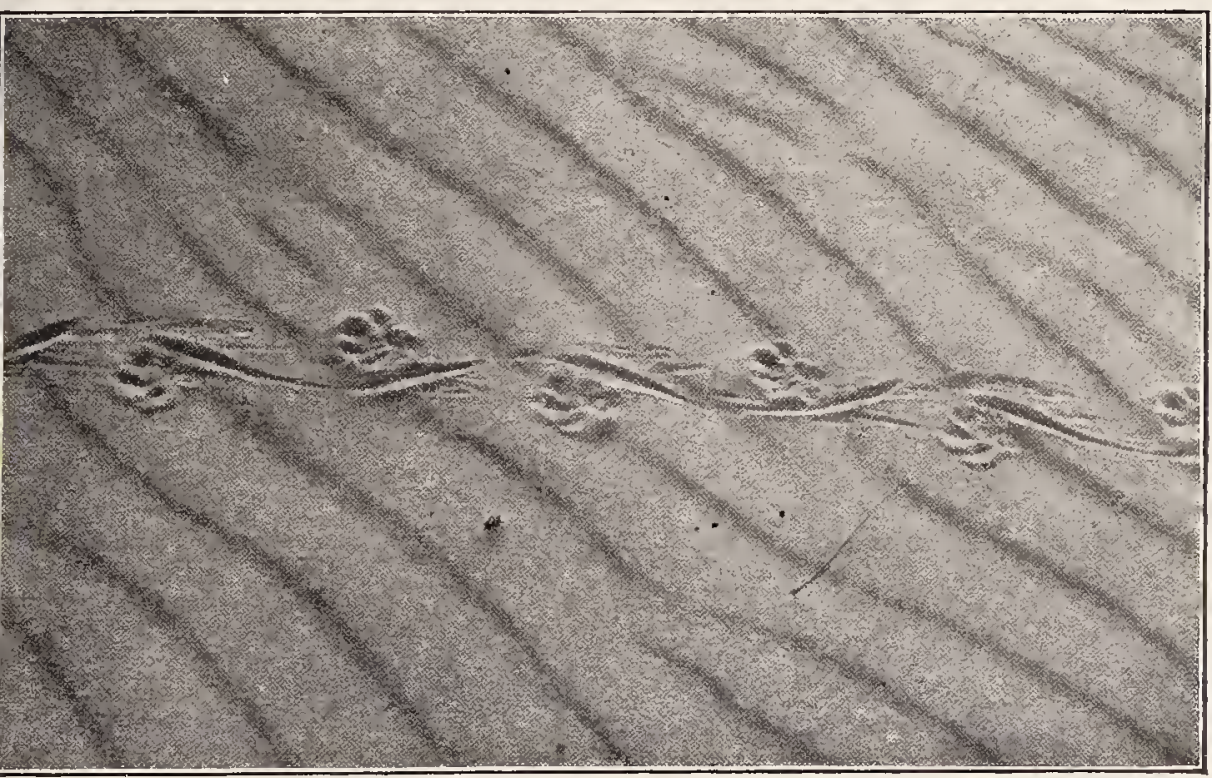

MUskrat Tracks. 



\section{TRACKS AND TRACKING}

vividly that I cannot do better than quote them here. And first Seton: "You never know where you may find a Jack - no one does - you never see it till it leaps at close range and lopes away in stiff four-cornered bounds, rising without effort, like an Antelope, and switching its great white brush from side to side like a miniature Whitetailed Deer; blazing with snowy white and punctuated with sharp black spots on his ears, it is the king of all his kind, the largest and finest of the Hares." And then Coues: "The first sign one has usually of a Hare which has squatted low in hopes of concealment, till its fears force it to fly, is a great bound into the air, with lengthened body and erect ears. The instant it touches the ground it is up again, with a peculiar springy jerk, more like the rebounding of an elastic ball than the result of muscular exertion. It does not come fairly down and gather itself for the next spring, but seems to hold its legs stiffly extended, to touch only its toes, and rebound by the force of its impact."

In running rapidly this great hare spreads its foot-prints in a line so that the track suggests that of a fox until the marks are critic- 


\section{SAND DUNES AND SALT MARSHES}

ally examined. At a slower gait it jumps like the familiar little cottontail, also found in the dunes, putting its hind feet in front and outside of its fore feet, and the tracks appear in patterns of fours. I have often followed the tracks of a jack for long distances, as he bounded in and out among the dunes, sometimes going down to the beach or up to the top of a sand peak. The abundance of tracks on the tops of some lofty dunes would suggest midnight sessions of the tribe. It is a great pity that this interesting animal is a thing of the past here, for he was certainly a charming feature of the dunes.

My most intimate relations with a jackrabbit occurred on January 27, 1907. Snow was spitting in biting gusts from the northeast and the thermometer was only twelve degrees above zero, a day when bird and beast might feel fairly secure from man. But the jack, whose tale I now relate, reckoned without his host, for in an Eskimo koolatuk and on snow-shoes I could comfortably defy the storm. My friend, the late Mr. Julian Dodge, who was ranging in front of me in the dunes, suddenly threw himself like a foot-ball player on a ball, and emerged from a snow-drift with 48 


\section{TRACKS AND TRACKING}

a great kicking jack-rabbit. He afterwards explained that he had caught sight of the rabbit's eye among some protecting grasses under a curling snowbank, and without hesitating a moment had pounced on his prey. To one who has tried to shoot this swift-running, elusive beast the tale may sound apocryphal, and I must in justification quote the following from Seton: "It is well known that the English Hare and the Common Cottontail will lie up, under stress of bad weather, letting the snow drift over them. There they continue several days without eating, and in a semi-torpid state, until aroused by some outside change for the better." This description fits the case exactly, except that the outside change was for the worse!

Reynard the fox now reigns supreme among the dunes. He has been a large element, doubtless, in the infant mortality of the jackrabbits and their untimely destruction. All is game, living or dead, that comes in his way, and he is fond of the fish and birds washed up on the beach, but the various wild mice are probably his chief dependence.

His tracks are everywhere in the sand, but should be carefully distinguished from those 


\section{SAND DUNES AND SALT MARSHES}

of his cousin the dog, who unfortunately also ranges the dunes at times. As a rule the tracks of the fox have such a clear, clean-cut appearance that they are easily recognized. Each foot is put down with care; there is no slouching $\mathrm{ol}^{\circ}$ shuffling, and each step is usually a stride. Most important of all, each footmark of the fox almost always shows two toes and claws projecting in front, while the footmarks of most dogs are nearly round. The one is slender and aristocratic, the other stubby and commonplace. One cannot always be sure of the identity of every track, but long practice lessens the chance of mistakes.

On a hot August day I followed some fox tracks, made evidently the night before, until they crossed the path of a toad. Suddenly the leisurely gait changed to bounds, there were some conspicuous scratch marks, and the toad tracks ceased. After that the fox tracks ambled on as before.

Near some other fox tracks I found a dead white-footed mouse with no mouse tracks near. Foxes apparently have a way of carrying mice in their mouths, and this must have slipped out unnoticed from an overfull receptacle. Captain Cartwright in his Lab- 



\section{TRACKS AND TRACKING}

rador Journal speaks of finding inside a trap, which had been sprung without catching the fox, "five large mice, which the fox had dropped out of his mouth."

Some years ago, from a study of tracks in fresh snow in the dunes, I concluded that crows sometimes spent the night roosting on the ground. With the increase of foxes there, I am inclined to think that this is no longer the case, but in April, 1910, I found fox tracks and the remains of a crow,- - but this of course may have been only a dead crow feast. Live crows are generally well able to take care of themselves; they need no protective coloration and have none.

Although foxes are abroad largely at night, I have not infrequently seen them by day. When first started they bound away in great leaps, showing the edges of their white bellies in contrast with their red sides; later they streak along, to use an appropriate slang phrase, close to the ground, their great brushes held straight out behind. As they disappear into a distant thicket the white tips of their tails are the last to show. One winter's day I followed some fresh fox tracks till they led me to some bushes overarched with 


\section{SAND DUNES AND SALT MARSHES}

a snow-drift. As I cautiously approached, a splendid fellow bounded out and fled to the peaked top of a dune several hundred yards away, where he deliberately sat down to watch me. I returned the compliment by levelling my binoculars on him, and found he was not the common red fox, but of the color-phase known as the cross fox. As I was watching him a flock of snow buntings swirled about him like a miniature snow-squall. He crouched low, with his eyes upon them, but they avoided the trap and swept on.

At another time I heard sounds of anger and indignation from the mouths of crows, and discovered three or four of these birds in the act of mobbing a fox, who, however, sauntered along, apparently not a whit disturbed, with his brush held straight out behind.

One can learn a good deal about the ways of the fox from these tracks without ever catching sight of the animal. Another source of information is the droppings, which are easily recognized and are common in the dunes. As these are made up largely of fur and feathers, and have been exposed to the purifying action of the sun and sand, they 


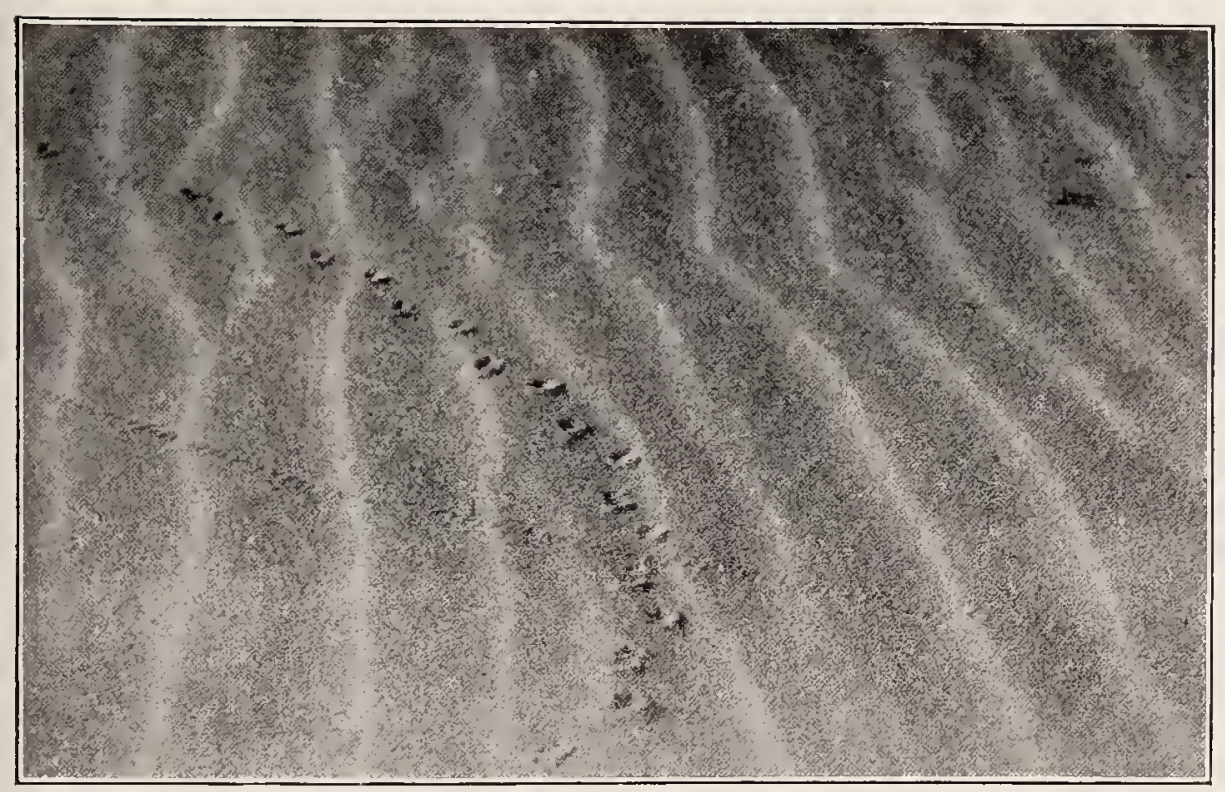

Tracks of a Meadow Mouse and of a Wooly-Beal Caterpiliatr.

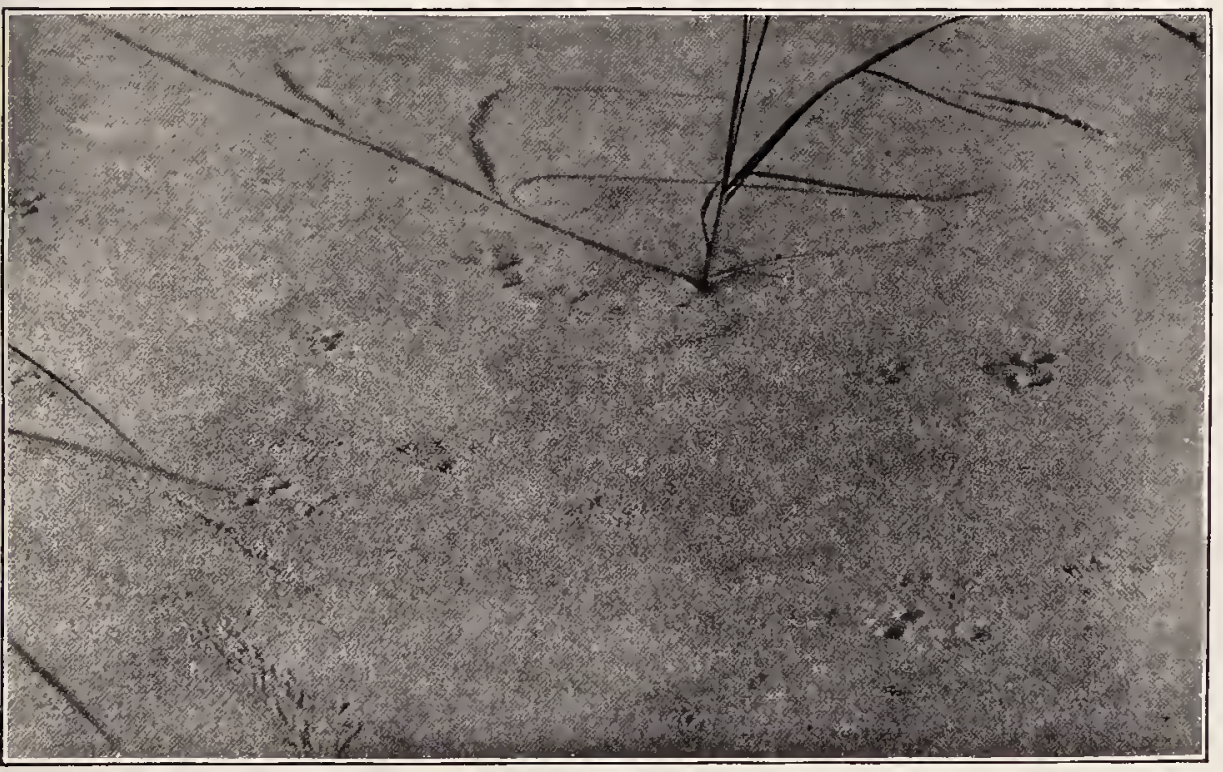

TRACKS OF WHITE-FOOTED MICE. 



\section{TRACKS AND TRACKING}

are as clean as balls of worsted. In fact their unravelling, with here and there an object in the form of a bone, a tooth or a claw, recalls the old form of lottery once popular at church fairs, where for a stipend one might unroll a ball of worsted until a prize dropped out. In both instances there is an element of chance which makes the game interesting, - it is more or less of a gamble. Sometimes there are no prizes, for the fur composes the whole of the droppings, which then resemble tapering cylinders of felt.

As a result of many unravellings of fur and feathers, I am able to present the following fox menu: portions of sand-fleas and seascuds and other small crustaceans; portions of June beetles and tiger beetles; bones of toad and frog; feathers of domestic fowl and of wild birds, large and small; bones of birds; claws of night heron and portions of skin of foot; sclerotic or eye bones of some bird; fur of mice and rabbits; bones of mammals; teeth of meadow mouse; teeth of young skunk.

The weasel bounds like a hobby-horse and leaves his foot-marks in pairs on the sand,round impressions about the bigness of one's thumb nail. These tracks are not common, 


\section{SAND DUNES AND SALT MARSHES}

but it is easier to find them than the beast itself, which, however, does not appear afraid when seen. I once heard the piteous squeaking of a meadow mouse, and saw a weasel bounding along, carrying the dying mouse in his jaws. He dropped it and retired to some bushes, but soon reappeared and bore off his prey, although I stood within a few feet of it. The brown summer coat of the weasel is exchanged in winter for the royal ermine-pure white with the exception of a black tip to the tail. One winter morning before it was fairly light I was walking to the dunes when I saw what appeared to be a piece of white paper blowing towards me. Within a few feet it suddenly developed into a lovely ermine that scurried by and disappeared among the snowdrifts.

The mink-midway between the weasel and the otter-is both a land and a rater animal. Although I have often seen him on pebbly shores of the ocean bordering on woods, l'umning out slyly and unconscious of my presence as long as I was motionless, I have never caught sight of him on the sandy shore of Ipswich. In the salt marshes, however, he delights to roam both summer and winter, 


\section{TRACKS AND TRACKING}

swimming the creeks and tidal pools in the summer, and climbing in and out among the ice cakes in winter. In the latter season he is a conspicuous object, for he does not turn white like his cousin, the crafty weasel, and his rich glossy brown fur contrasts well with the ice. One of these fellows, wandering among the ice floes stranded on the marsh, met death at my hands in those days when I " observed" as frequently along the shining barrel of a gun as through a glass, and his beautiful skin still serves in arctic weather as head-gear for his slayer.

A dozen small fish left on a log on a marsh island during a cold night disappeared utterly, so that my breakfast was a scanty one, while a mink was undoubtedly pleased with this singular change of habitat on the part of the fish.

If the mink combines in himself the weasel and the otter, he also shows some relationship with the skunk, for he is capable of producing a most abominable odor, but little inferior to that of the latter well known animal. His tracks I have often found; they resemble those of the skunk but are considerably smaller, and the claws are more prominent. A drop of 


\section{SAND DUNES AND SALT MARSHES}

bright blood near his tracks stamps his murderous character.

Only occasionally, when there is plenty of water in the dune bogs, do the tracks of muskrats appear on the sand, and strangely enough I have found them leading from one bog to another over dry stretches of dune land. The marks of the webbed hind foot can sometimes be plainly made out, while the median groove formed by the dragging tail is a conspicuous feature, and makes the diagnosis easy.

The skunk is certainly a beach-comber, but his visits to the strand are with very rare exceptions made only at night. The beach is a happy hunting ground for him, because, like the fox, he enjoys the varied and gamey diet that the place affords, and his tracks abound there. They are also spread like a network over the dunes, with here and there a small pit where he has dug for grubs or cut-worms. The footprints are often beautifully distinct in the sand, and show each toe and claw, and these as well as the gait are characteristic.

I once had an excellent opportunity to study the gait, not merely in the tracks, but in the living animal. With a friend I came upon a skunk on the upper beach, and, by heading 56 


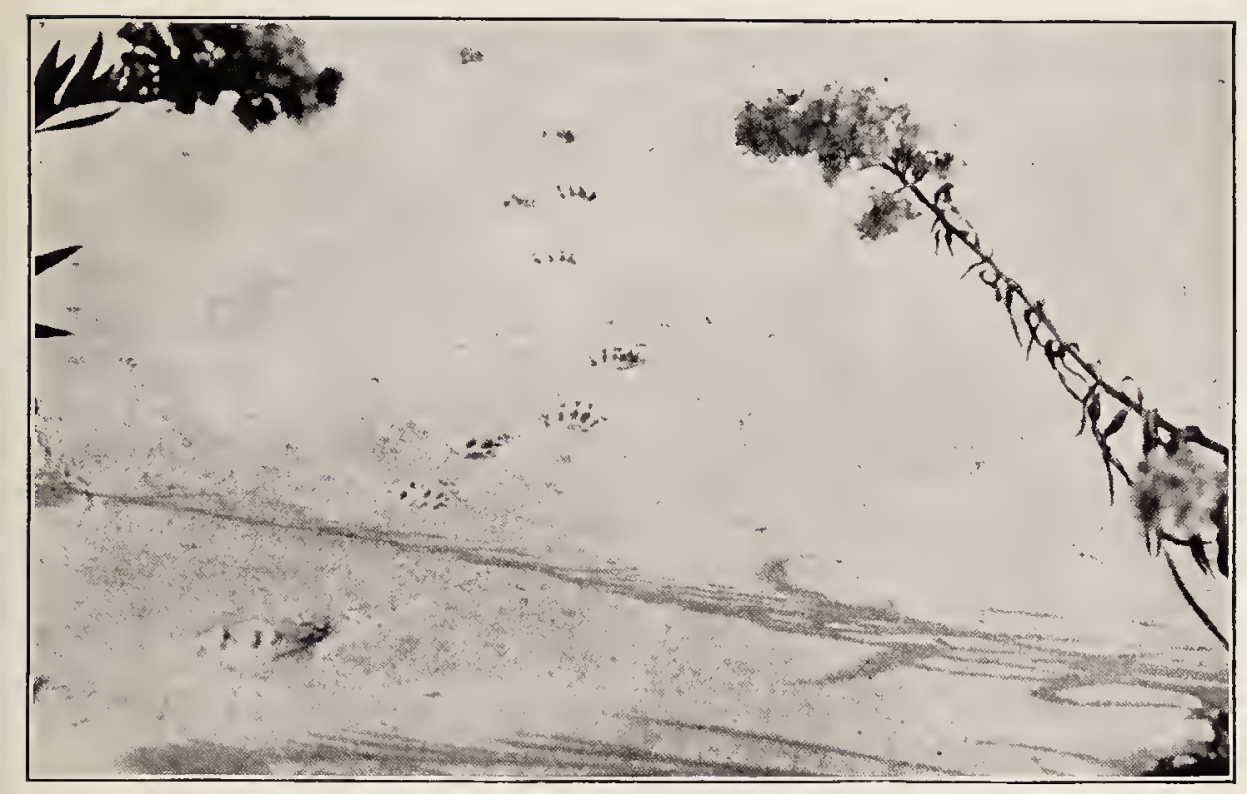

Shuni Trackg.

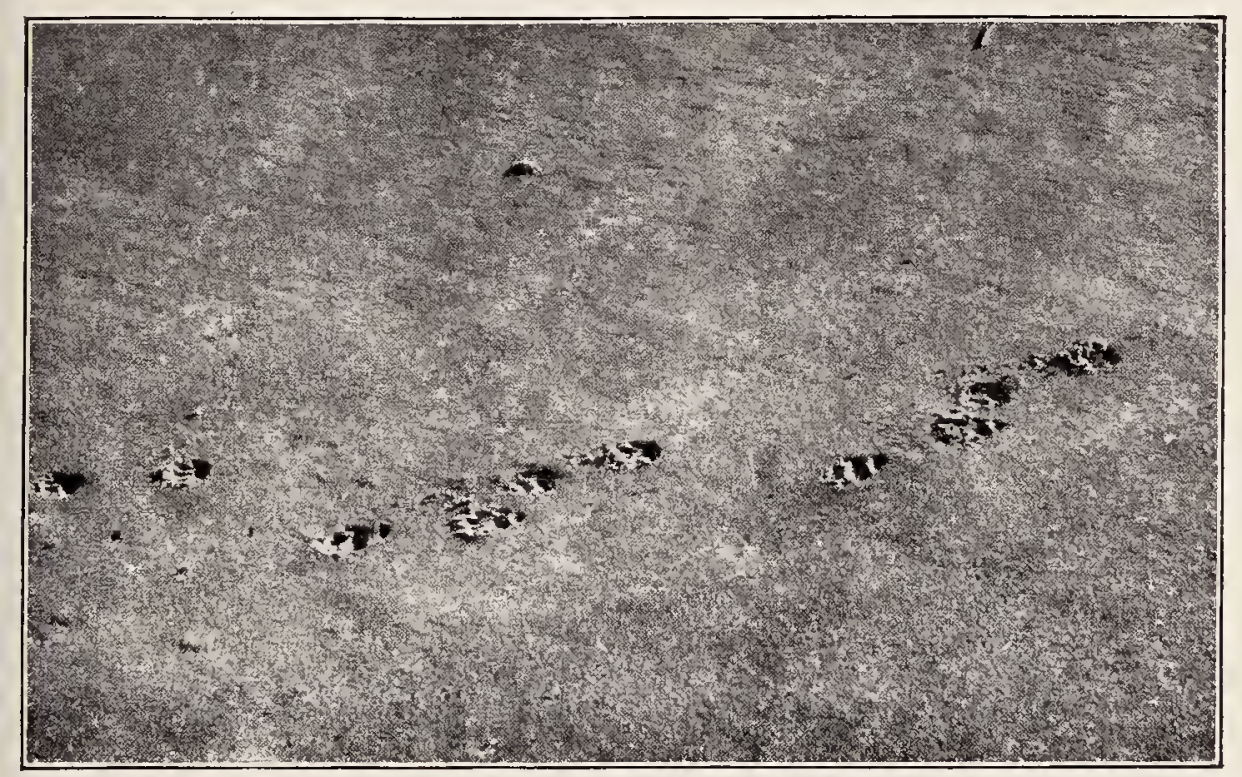

Tracks of a SKUNK IN A Hurpy. 



\section{TRACKS AND TRACKING}

him off from the dunes, we were able to drive him down to the edge of the waves, although we always kept at a discreet distance and watched his tail. The animal was evidently enraged by our manoeuvres, and showed his displeasure by turning and facing us from time to time and stamping his fore feet on the sand. One of us then walked behind him as he ran along the beach, while the other prevented his escaping from the water's edge by walking between him and the dunes. When once started, this triangular procession continued along the beach for about half a mile. At the end of this march, owing to human caprice, the order became single file, with the skunk in the middle, and the extremities of the column closing up on the centre. Each of the out-guards endeavored to drive the centre towards the other, but each out-guard was secretly and cowardly prepared to turn and flee, if the centre showed the danger-signal by elevating its tail. The climax was disappointing and unsensational, for the skunk, no longer debarred from its haven, the dunes, made off at right angles for this refuge and disappeared, leaving the end-guards discomfited, but in an atmosphere undefiled. How- 


\section{SAND DUNES AND SALT MARSHES}

ever, my notes say that the speed of the animal along the beach was about four miles an hour, and that the gait was a peculiar one in that the fore legs trotted while the rear legs seemed to hop or gallop, so that the front part of the body kept an even level while the back part bobbed up and down.

Although the ordinary gait of the skunk is a very leisurely one, I once found tracks which showed that the animal was bounding over the sand in long strides or leaps, because his four feet came down in linear patterns with considerable gaps between each set. $\mathrm{He}$ must have been frightened by a ghost for, well armed as he is, he is afraid of nothing made of flesh and blood.

The odor of the skunk is almost never noticed in the dunes. Its presence generally means a meeting with a dog or a gunner.

Skunk droppings are often made up wholly of insects, such as beetles and crickets, although I have found the bones of birds and mice, their feathers and fur, as well as bits of grass and seeds. It is possible that the last named were accidental additions to the diet.

Mice tracks in the dunes are for the most part made by white-footed mice and meadow 


\section{TRACKS AND TRACKING}

mice. The former often bounds along, leaving tracks in fours like a miniature rabbit, while the meadow mouse leaves his tracks in a line or in pairs, and near together. The marks are often very clear, showing all the toes and foot pads. Noticing a multitude of tracks of the white-footed mouse near an old $\log$ in the dunes, I lifted it, and there curled up in a soft nest were a pair of these delicate large-eyed mice.

Occasionally one comes across tracks of a larger size made by rats. Where the beasts come from I do not know, but it is evident that they exist in these sands, for they once made an entrance into my dune camp and left traces of their destructive work, which might have been serious had it not been discovered early.

By far the commonest of all-the-year-round bird tracks in the dunes are those of the crow. One can observe the force with which the birds alight, the fact that after alighting they sometimes bound forward once with both feet together, and that they are very apt to drag their middle toe or even all their toes when they are particularly tired or lazy. Nevertheless they walk with long strides, and on rare 


\section{SAND DUNES AND SALT MARSHES}

occasions only do they hop. Their toe-marks show knobby protuberances, as if they suffered from the gout. As they rise into the air, their wing-marks are sometimes imprinted on the sand, and I have seen places on the snow where they have slipped in walking and spread out one wing to save themselves.

Crows give an easy clew to their feeding habits, as they have a custom of ejecting from their mouths pellets of partially digested food. These pellets are plentifully distributed in the dunes, especially in certain localities where the birds roost. They are one or two inches long, tapering at the ends, and a half to threequarters of an inch thick. In summer these pellets soon fall to pieces, but in freezing weather they retain their shape. Their most common constituents, by which they may be recognized at a glance, are bayberry or wax myrtle seeds. A few of these seeds are ejected with the waxy coat still intact, but most of them are entirely denuded of it. Cranberries, whole and in fragments, the red furry seeds of the sumach, the seeds of the poison sumach, of grapes and of the bitter-sweet are also common. I have found pellets that were made up 


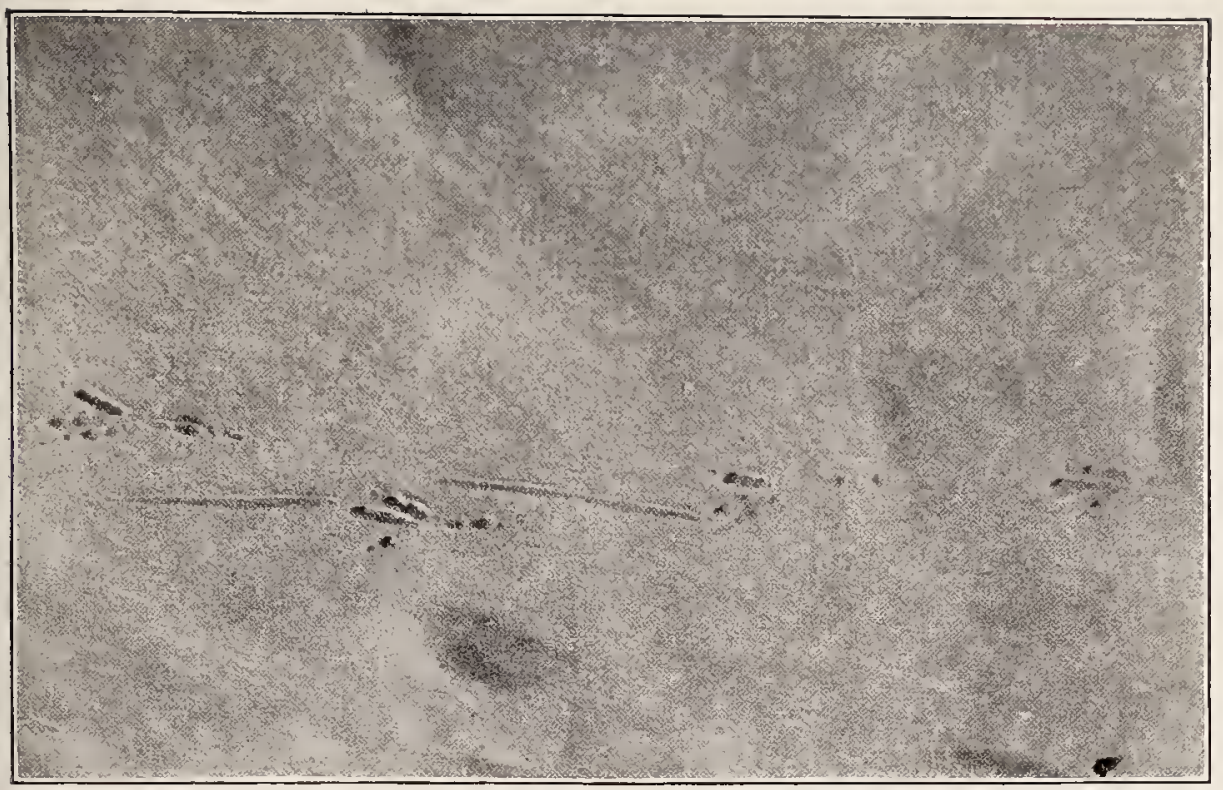

Tracks of a Crow.

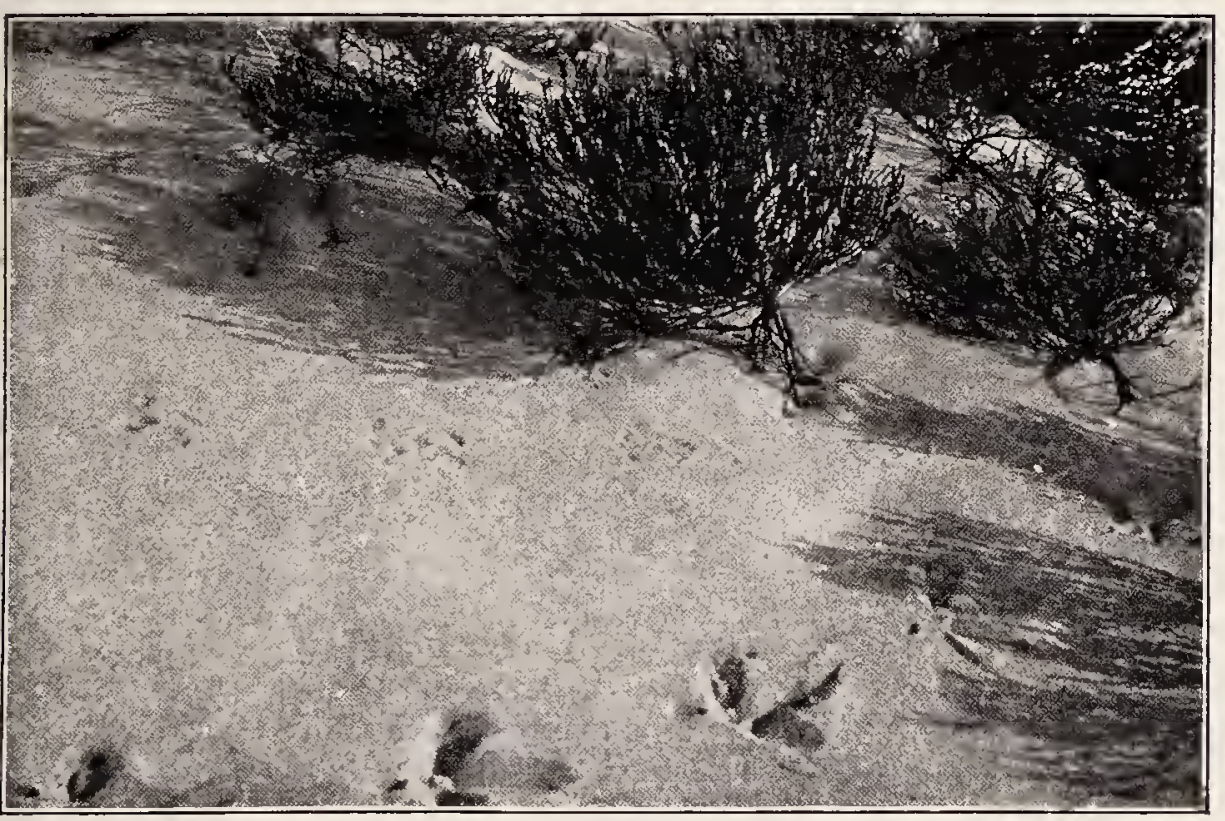

Hudonia Plants, Tracks of White-Footed Mouse and of Pueasant IN Soft SAND. 



\section{TRACKS AND TRACKING}

almost entirely of whole cranberries or whole bitter-sweet berries, so that it would seem as if their greediness had led the crows to adopt the old Roman custom, that they might gorge the more.

Besides seeds and berries the pellets are very apt to contain the shells of the little black-footed univalve-Melampus-so abundant in the salt marshes, as well as those of periwinkles, sea-snails, mussels and clams. Portions of crabs are also common, and occasionally one finds bits of June bugs and of tiger beetles, and bones of fish, frogs and mice.

The fondness of crows for other birds' eggs was clearly revealed to me one May day. A few broken remains of a red-winged blackbird's egg, surrounded by the tracks of a crow-that was all, yet it explains the insistent ferocity with which red-wings chase crows from the thickets. The bill of fare of the crow is a varied one!

The ring pheasant frequently strides among the dunes, leaving tracks very different from those of the crow; the three toe-marks in front are widely spread, and there is no mark of the hind toe except where he goes down an 61 


\section{SAND DUNES AND SALT MARSHES}

incline or the sand is soft, and then only a dot shows. In an ordinary walk the distance between the foot-marks is seven or eight inches, but when running the bird sometimes strides twenty-two inches.

I once watched a bald eagle perched on a dune overlooking the sea, and after he had flown away the markings of his tail and wings, as well as of his feet, were plainly to be seen where he had stood in the sand.

Prior to 1904, the tracks of piping plover might occasionally be found in the spring spread thickly about the spot where their eggs were laid in slight depressions in the sand of the dunes, but now these birds no longer breed there.

In the latter part of the summer, tree swallows alight among the dunes and leave tracks of their brief walks made with short steps, bordered here and there by marks of unmanageably long wings, and punctuated with an occasional dropping containing bayberry seeds. Footprints of many birds are always to be found in the sands, but when the winter birds come in great flocks, - the snow buntings, horned larks and Lapland longspurs, all walkers, - then indeed is the sand well in- 


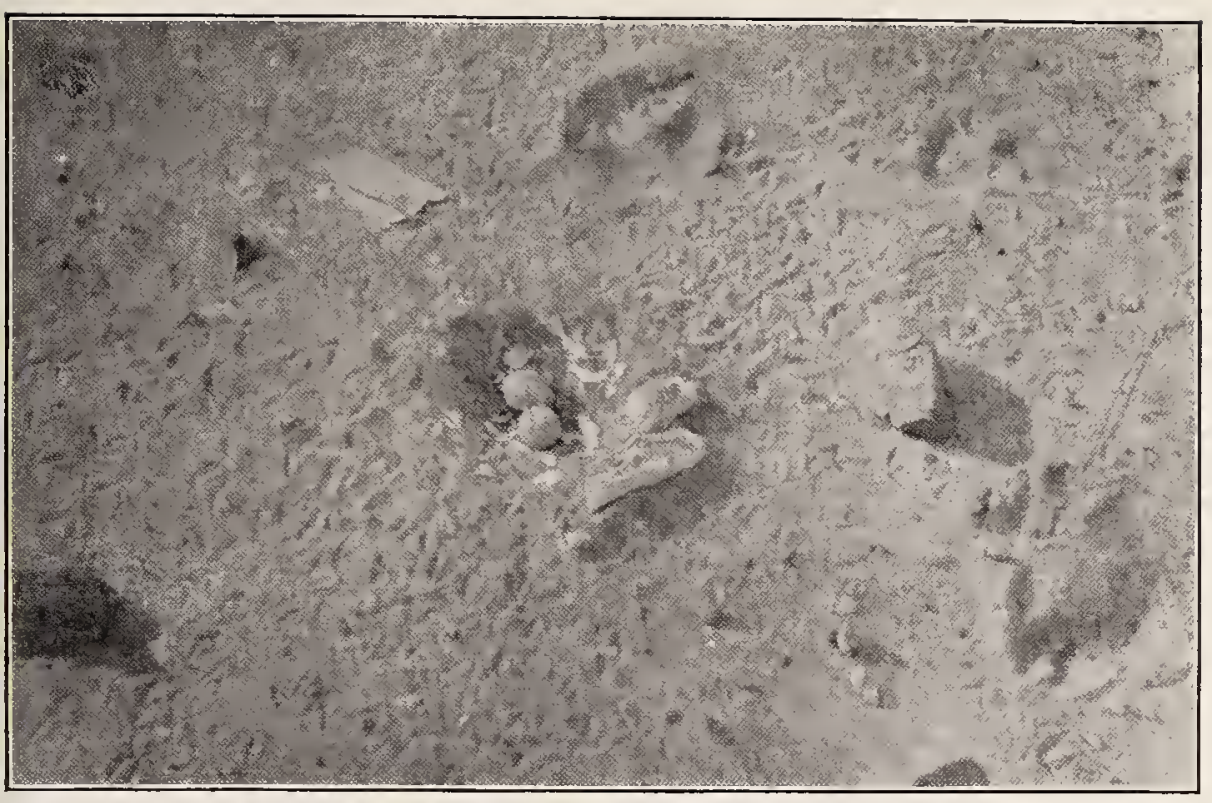

Tracks and Eggs of Phing Plover.

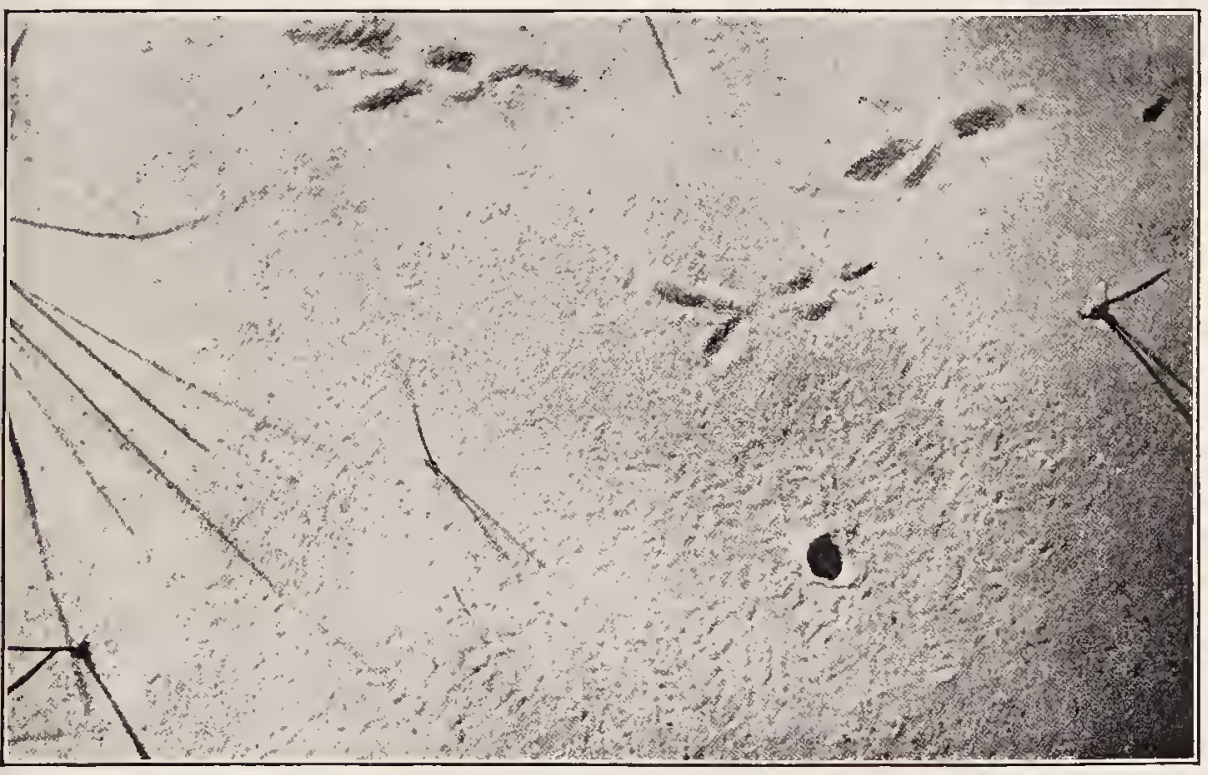

TRacks of SAVANyAH SPARROW AND SAND DUNE SPIDER AND HOLE OF LATTER. 



\section{TRACKS AND TRACKING}

scribed. All of these, but particularly the last named, have long hind toes and claws.

It is very seldom that one finds the tracks of flickers, but they are easily distinguished by the two toes in front, the two behind and the hopping gait.

Although gulls often alight and leave their tracks in the dunes, the footprints of sea birds are best studied on the damp beach, and a chapter might be written on this subject alone. The most characteristic of these tracks are those of the shore birds, and one can easily distinguish the records of plover from the records of sandpipers, both by the footprints and by the bill-marks. Flocks of plover spread out irregularly on the sand, and leave tracks running in various directions and constantly crossing, while the sandpipers have more team play, and run along the beach, up and down before the advancing and retreating waves, but always together. The sandpiper, with head down nearly all the time, drills the sand with his long bill, and leaves behind him an almost uninterrupted series of holes close together for the space of a foot or more, then a blank space where only his footprints show as he hurries along, swallow- 


\section{SAND DUNES AND SALT MARSHES}

ing his prey, then another series of holes, and so on. Not so the plover; he strides along with head up, but every few seconds he strikes the sand a blow with his short bill for a minute crustacean or worm below the surface. These dabbings of the semi-palmated or ring-neck plover are small, while those of the blackbellied plover are large and are usually two or three feet apart and generally double, which means that the eager bird struck the sand with bill partly open. The footprints show three toes wide apart.

At night the beach is often lined with night herons, and their tracks, as well as those of their much larger but less common relative, the great blue heron, and also of the small green heron, are easily recognized.

When the herring gull alights on the beach, both feet come down together, or nearly so, with considerable force, and thrust slightly forward, as is shown by the deep impressions in the sand at the back of the track. Occasionally the birds strike so flat-footed that the tarsus cuts the sand like a long hind toe. Their webbed footprints sometimes cover the sand thickly for many yards, with here and there a pellet of fish bones, and with feathers 64 



\section{TRACKS AND TRACKING}

as thick as in a poultry yard. If there is a strong wind, gulls are able by a step or two directly toward it to launch their great aeroplanes into the air, but on calm days they run forward vigorously with wings spread, and, as they are gradually borne aloft, the feet still push at the sand until the tips only of the claws make imprints. The distance of the run' is inversely proportionate to the velocity of the wind.

A curious habit of herring gulls leads to peculiar tracks. I refer to the fact that they not infrequently drag dead fish in tortuous courses from the upper beach down to the water. A dead hake eighteen inches long I found had been dragged one hundred and thirty-four paces to the water, and, from the tracks, it was evident that the gull had laboriously walked backwards all the way, pausing from time to time and relinquishing its beakhold on the fish. The fish was certainly gamey enough to need a salt water souse, but the gull's object was possibly to soften it. This action on the part of the gull seems to me to deserve credit for something more than mere instinct. I cannot help thinking that the lower animals, in unusual actions of this sort, 


\section{SAND DUNES AND SALT MARSHES}

display an intelligence akin to our own, and that the sharp line between instinct for them and reasoning power for us should not be drawn. The Lord only knows how much of our own boasted intelligence is merely instinctive; I have known dogs that have shown more reasoning power than I have seen displayed by some stupid people. I have a parrot that shows its intelligence in the same manner as the gull by taking hard bits of cracker to its water jar and soaking them before it eats them.

The common habit of herring gulls, as well as of crows, of dropping clams, sea-snails $\mathrm{ol}^{\circ}$ crabs from a height in order to break their shells, accounts for the multitude of these objects both in the dunes and on marsh islands. As its prey falls, the bird drops down after it, and sometimes repeats the process again and again.

On disturbing a pair of sheldrakes or redbreasted mergansers one calm day from their comfortable nap on the beach, I found in the sand record that they were obliged to stride forward twenty-nine yards before they could push the beach away from them. Their strides were three feet long, and the duck 66 


\section{TRACKS AND TRACKING}

led the drake in the race. They were unable to head for the little wind that was stirring, for I was on their windward side and the ocean was to leeward, so they were doubly handicapped. Had the wind been blowing harder, they would undoubtedly have risen against it,-towards me. The case of the black duck is very different. Its leisurely walk, with short steps and toes turned in, is easily traced in the sand to where the track ends abruptly as the powerful wings take the bird straight up. The final footprints are not perceptibly deeper than those that precede, showing that it is their wings and not the push of their feet on which they depend.

It is not often that double-crested cormorants or shags alight on the beach, but their tracks are worth recording. With their stiff tail feathers they scratch the sand in places, while the base of the curious foot makes a deep depression in the sand, and the three front toes with nails are plainly shown, as well as the nail of the fourth toe, which makes a mark at the side; in places there are indications of the web which connects all the toes. In rising both feet strike out together in a hop instead of a stride. 


\section{SAND DUNES AND SALT MARSHES}

On some desert sands the tracks of many reptiles are found, but in these northern seashore dunes it is rare that one comes upon the winding track of a snake. A member of the group of batrachians, the common or garden toad, here, however, so sandy in color as to deserve the name of dune-toad, leaves his tracks everywhere in the summer, and from their bizarre shape and great abundance they are certainly a surprise to the uninitiated. Concealed in the daytime beneath a board or $\log$ or in a burrow in the sand, the toad is rarely seen, but he makes up for his sluggish days by great activity at night. I have often followed a toad track until I became tired of the pursuit, for the animal travels surprising distances, often, curiously enough, in a straight line over hill and dale among the dunes.

Of insect tracks in the dunes there is a goodly quantity, from those of the grasshopper, which, owing to the multitude of footprints, suggests a milliped, but whose hopmarks are deep and abrupt, to the transitory ones of the restless tiger beetle, as he alights for a moment, and from those made by the excursions of the staghorn beetle to the 68 


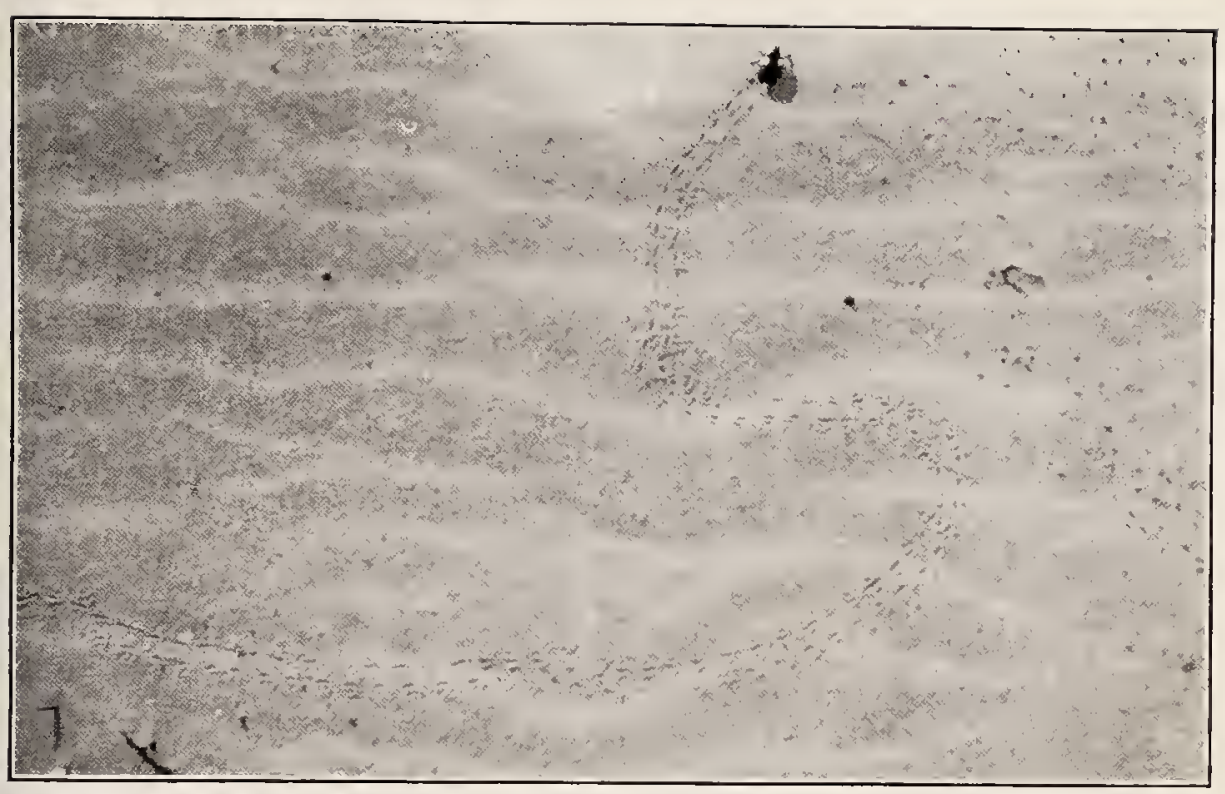

Staghorn Beetle and Tracks.

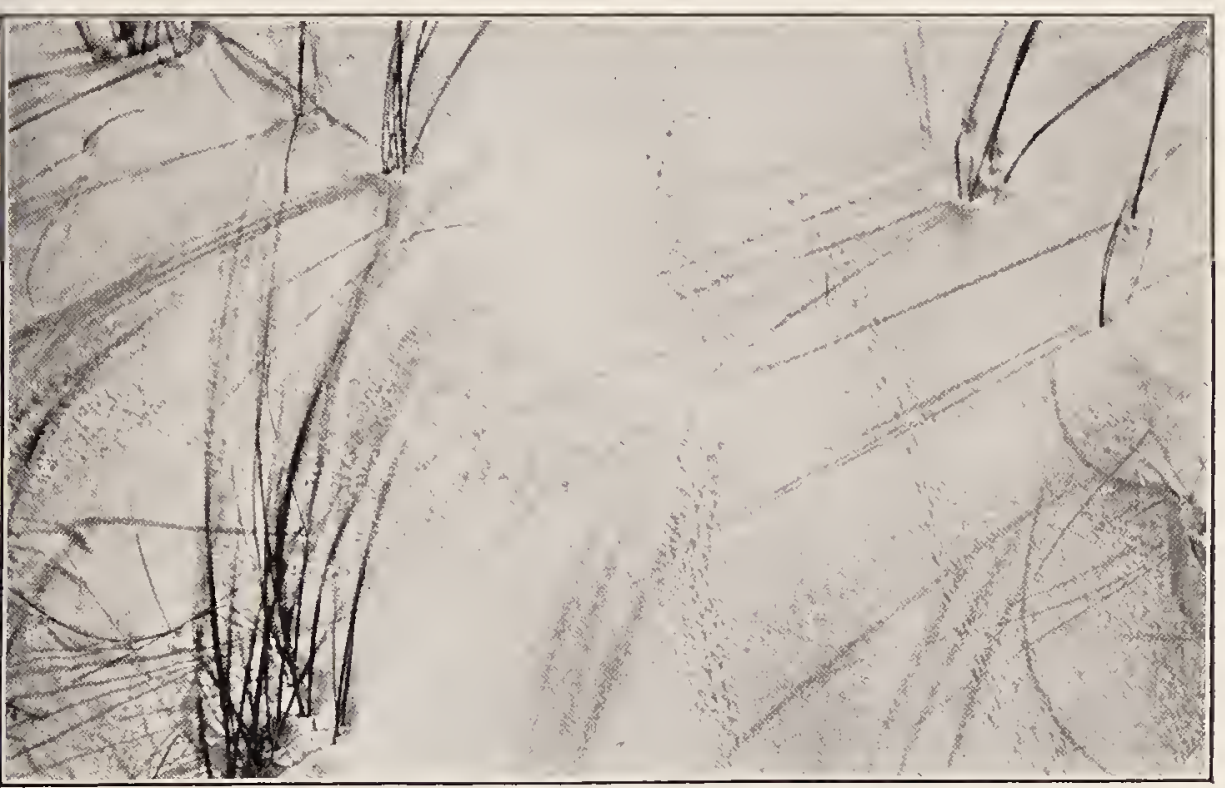

TRACKS OF SAND DUNE GRASSHOPPERS. 



\section{TRACKS AND TRACKING}

worm-like marks of various larvae. Like the toad and the Ipswich sparrow, the dune grasshopper, and to a less extent the dune tiger beetle have become sandy in appearance protectively colored.

Another creature that is protectively colored is the sand dune spider-or to speak more correctly, the male sand dune spider, for he alone spreads his tracks in the sand. The female, who lives in a hole, needs no protective coloration.

The study of ichnology and scatology in these sandy wastes is as absorbing as a detective story. 


\section{CHAPTER III}

\section{VEGETATION IN THE DUNES}

"No daintie floure or herbe that growes on grownd, No arborett with painted blossoms drest

And smelling sweete, but there it might be found To bud out faire, and throwe her sweete smels al around."

- SPEnser.

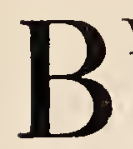

$Y$ far the most characteristic plant of the dunes, one that is of great economic importance in that it restrains by its binding network of roots the movement of the sands, is the cosmopolitan beach grassthe maram-grass of East Anglia-a plant which by its scientific name reiterates both in Greek and in Latin that it is a sandy sand lover. Everywhere it extends its long, creeping rootstocks, sending up at the ends its spiny-tipped leaf-blades, sharp and hard as a needle, where they emerge from the sand. Tangles of withered stems and rootstocks hang in festoons from the steep retreating sides of the dunes, but on the leeward side the grass struggles bravely above the engulf- 



\section{VEGETATION IN THE DUNES}

ing sand. In the comparatively level stretches back of the beach, the grass grows to greatest perfection and reaches a height of two or three feet, growing thickly, dark green and shining in summer, and bearing pale yellow fruiting stalks in the autumn. As the winter comes on the green gradually fades, but is replaced by a golden straw color, that like a luminous yellow haze spreads over the sands. While the beach grass is beautiful in mass, with its colors varying with the season, the individual clumps and sprays of graceful upright and drooping grass stems, and rigid plumes of flower and fruit are exceedingly picturesque in their brilliant white setting of sand. Around each clump is often drawn a magic circle, a fairy ring, for the drooping grass blade, blown by the wind, writes with its tip in the soft sand.

Another plant which binds the sand has the singularly inappropriate name of povertygrass, for it is not a grass, but a member of the rockrose family, and it expresses anything but poverty, if one is to judge by its wealth of golden blossoms, which paint the dune sides yellow in June. Rather should it be called by its own name, Hudsonia, given it in honor 


\section{SAND DUNES AND SALT MARSHES}

of William Hudson, an early English botanist. Matted together like heather and close to the sand, it forms in summer great patches of a beautiful sage green, which in the autumn are tinged with yellow, and in winter become sandy gray, while in the spring all is smothered in the brilliant yellow of the closely crowded blossoms. The Hudsonia is a plant well worth knowing.

In the dry sand a number of interesting and characteristic plants are to be found, some of which prefer the sea side of the dunes close to the beach. The American sea rocket is one of these, a plant of the mustard family, with small purplish flowers, but swollen and dropsical like a sand-loving cactus. Another swollen cactus-like plant is the saltwort, cactuslike also in that it is beset with sharp points, woeful things for the bare foot.

The resemblance of these plants to the eacti is not wholly accidental, for, like cacti, they are growing to a certain extent under desert conditions, and it is incumbent on them, therefore, to treasure up as much moisture as possible. In the dunes the air always contains moisture, and the sand is wet a few inches down, no matter how dry it may be on the sur- 


\section{VEGETATION IN THE DUNES}

face, yet the strong winds, the intense light and great heat radiated from the white sand approximate the conditions of a desert. Both the desert cacti on the one hand and the sea rocket and saltwort on the other conserve moisture by making reservoirs for water in their stems and leaves, taking on a fleshy habit, in the language of the botanists. The saltwort also resembles the cacti in its spiny defenses. It always seemed to me a cruel state of affairs that in the deserts, where vegetation is so scanty, the plants should be so forbiddingly spine-covered; but after all $\mathrm{Na}$ ture always looks after the individual, she is not altruistic. These sand dune plants are then true xerophils,-lovers of dryness.

In the same situation near the edge of the beach grows the cockle-bur with its beaked and spiny fruit, and also the salt-loving orach.

In photographs of the semi-arid regions of eastern Africa, one sees great spreading trees, giant candelabra, under which the rhinoceros takes his noonday siesta. These are euphorbias or spurges, and here throughout the dunes a lowly member of the same family, the seaside spurge, spreads itself in mats from the size of a silver dollar to that of a large 


\section{SAND DUNES AND SALT MARSHES}

saucer, prostrate on the sand. By a central tap-root it draws its nourishment from the damp sand below. The purple gerardia, closely akin to the seaside gerardia of the salt marsh, and the joint-weed, with its delicate rose-colored or white blossoms that appear throughout the fall, are also common.

The beach wormwood is another plant of these sandy regions, a plant brought from northwestern Asia, but one that has rapidly increased in numbers on the Atlantic shores in the last thirty years. It is the "dusty miller " of old-fashioned gardens, and I am inclined to think that at Ipswich it escaped into the dunes from the old lighthouse-keeper's garden. 'There is also one patch of bearberry in the Ipswich dunes.

Each species of goldenrod-and there are over fifty in eastern North America-has an interest and beauty of its own, but the saltloving species, the seaside goldenrod, which is equally at home on the edges of the dunes and on the border of the salt marshes, is certainly one of the finest, with its dark green vigorous leaves and its robust flowering stalk of large golden flowers. Long after the flowers have succumbed to the frosts the stalks 


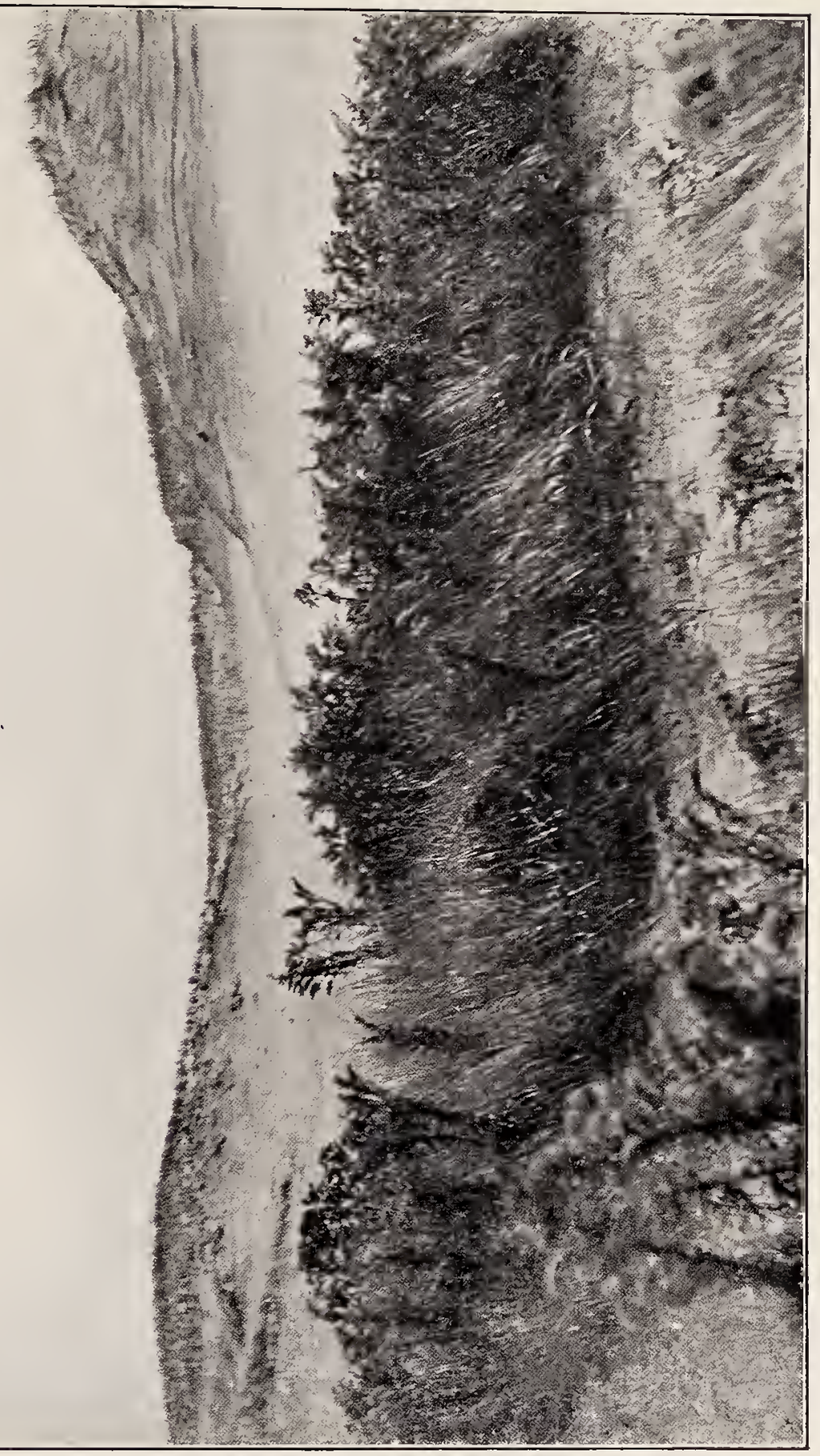

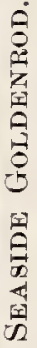





\section{VEGETATION IN THE DUNES}

stand up like gray plumes waving in the wind. While the cultivated sweet pea does not blossom unless it has an abundance of moisture, its wild relative, the beach pea, with its purple flowers and rich green leaves, thrives amid the dry sand and bears plentifully its flowers and small round peas.

One would hardly expect to find mushrooms growing in the dry sand, but there are a number such, both on the bare wastes and among the groves of trees and bushes. The most noticeable one is the sand-star puffball, which in wet weather stretches its leathery-looking star flat on the sand, and holds on its upper surface a puffball not much larger than a hazel-nut. In dry weather the leathery arms of the star curl up dry and brittle around the puffball, as if to protect it from the sun. Common in the dunes is a brown mushroom whose stem, swollen and bulbous, extends down some distance into the sand, as if to retain as much moisture as possible.

The depressions between the dunes, which vary in size from small circular basins but a few feet across, to valleys a third of a mile broad between the amphitheatre waves, are to a large extent carpeted with cranberry 


\section{SAND DUNES AND SALT MARSHES}

vines. In the large bogs the vines extend upwards in a thick spongy mat, into which one sinks half-way to the knee, while in the smaller depressions the vines often run prostrate in a thin branching film of great beauty over the white sand.

The American cranberry is worthy of the poet's pen, for at all seasons it is a delight to the eye, while of the pleasures its fruit affords to the palate there is no need to speak; it suggests the delights of the New England Thanksgiving. In the spring its pale rosecolored flowers, nodding on delicate stalks, in summer the brilliant polished green of its leaves, are but the prelude to its varied charms in autumn and winter. The botanists call it evergreen, which is literally true only as regards the under protected leaves, but all on the surface change in the fall to a dark red, and later to a wonderful maroon color, which, in the setting of white sand, is regal in its effectiveness.

Early in the summer, after the delicate blossoms have fallen, tiny pale green or whitish berries appear, which gradually grow in size and grace, taking on successively a pink, a brilliant crimson, a dark red and lastly a pur- 


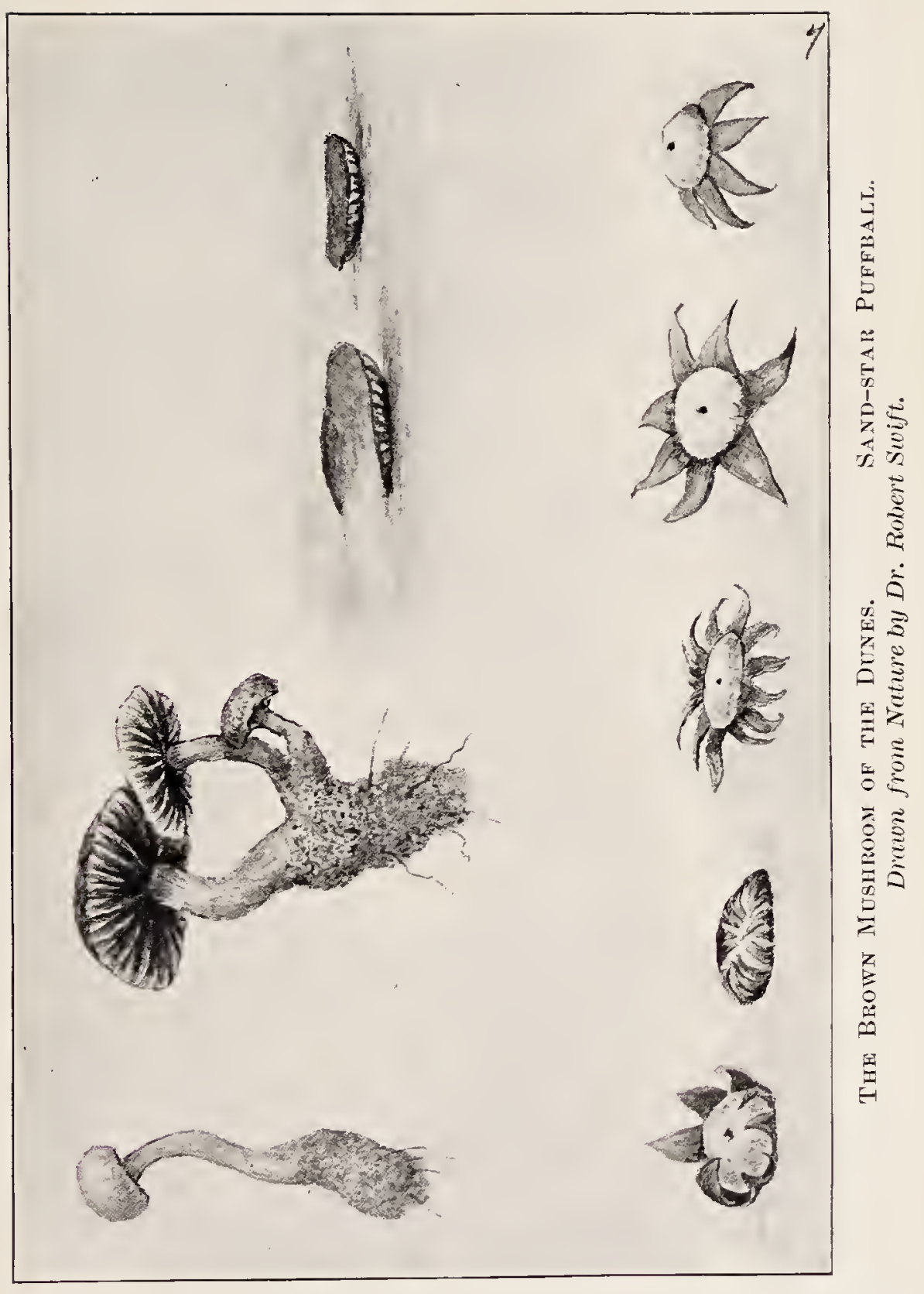





\section{VEGETATION IN THE DUNES}

ple color. Fortunately in these dunes no attempt at cultivation is made, there is no dyking nor draining, no weeding nor planting, so that the cranberry vine grows with its native grace and freedom. Many berries escape the pickers in the large bogs, and many of the small bogs, hiding among the dunes, are overlooked entirely. Some years the frosts come early and all the berries are lost to commerce. Other years several hundred barrels are picked by hand and with box rakes. In any event the dune wanderer can always pick his pockets full, and, with a little water and much sugar, may quickly convert the berries over the fire into a delicious "sauce." I have often gathered them from beneath the snow, and their fine resistant qualities keep them sound even when in the spring floods they are floated away and line the shores of the bog pools in windrows. I once for a record made a good sauce of these berries on the first of June.

Another great attraction these natural cranberry bogs have which the artificial ones lack is their wealth of extraneous plants,-herbs, bushes and even trees. In fact some of the bogs are so overgrown that the cranberry 


\section{SAND DUNES AND SALT MARSHES}

vines take but an insignificant part. Clumps of blue irises are beautiful in the spring in their cranberry vine setting, and when, as occasionally happens, they escape from their environment and blossom in the white sand, they look for all the world like a picture on a Japanese screen.

There are two lovely orchids which bloom abundantly in the early summer in the bogs, Pogonia, the bearded-one, with its pinkish flowers generally single, and Calopogon, the beautiful bearded-one, with its half dozen or more clustered flowers, whose color, according to Gray's . Manual, is " magenta-crimson." The very name orchid has an interest and charm, but it is certainly deserved in the case of these two dune-loving orchids, for they are extremely beautiful.

Another interesting bog-plant, with leaves so divided that they suggest the royal fern, one that is common on the southern seacoast of the Labrador peninsula, is the Canadian burnet. This blossoms in midsummer in long cylindrical spikes of white flowers. A more modest but most interesting inhabitant of the bogs, one that grows abundantly in places, is the sundew, which owes its name to the dew- 



\section{VEGETATION IN THE DUNES}

like drops that glitter in the sunlight on the tips of the bristles covering the little round red leaves. This "dew" is not so innocent as its name would seem to imply, and leads to the death of tiny insects. Attracted by the dew, which is secreted by the plant, the insect alights, and is held there by the glutinous fluid and also by the tiny hairs which bend over and enclose it. At the same time a digestive secretion is poured out, under the action of which the nutritious parts of the victims are dissolved and absorbed. It is rare to find a plant without one or more insects in various stages of digestion on its leaves. They are veritable charnel-houses. The flowers are borne on stalks and are white and inconspicuous. In the shady bogs grow also clumps of the beautiful royal or flowering fern, as well as the sturdy interrupted and cinnamon ferns.

Before taking leave of the smaller plants I should mention another orchid, the lady's slipper, which, however, is hardly a sand dune plant, for it demands the sheltering environment of the pitch pines that grow among the dunes. In May and June its beautiful crimson pink flowers nod upon their stalks. Moc- 


\section{SAND DUNES AND SALT MARSHES}

casin flower is its proper name, for in its broad and swelling outlines it resembles much more closely the Indian moccasin than the pointed lady's slipper.

Of the bushes growing in the dunes, the beach plum is the most characteristic, a straggling prostrate shrub where it is exposed to the full force of the wind, but expanding luxuriantly in the protected hollows. In the early spring it is a mass of white blossoms, and in the fall the small globular purple or crimson fruit can be gathered. There is a wild flavor about it not unattractive. It is not common at Ipswich, but abounds at Plum Island, from which, indeed, the island takes its name.

Everywhere in the dunes grows the bayberry or myrtle with its fragrant leaves and aromatic, wax-covered berries, the favorite food of four different kinds of birds, namely, the flicker, crow, tree swallow and myrtle warbler. In fact the myrtle warbler not only owes its name to the berries, for the older name of yellow-rumped warbler has been discarded, but also its ability to brave the northern winter when all its companions of the same tribe have fled to warmer climates. The early settlers found these bayberries useful 80 


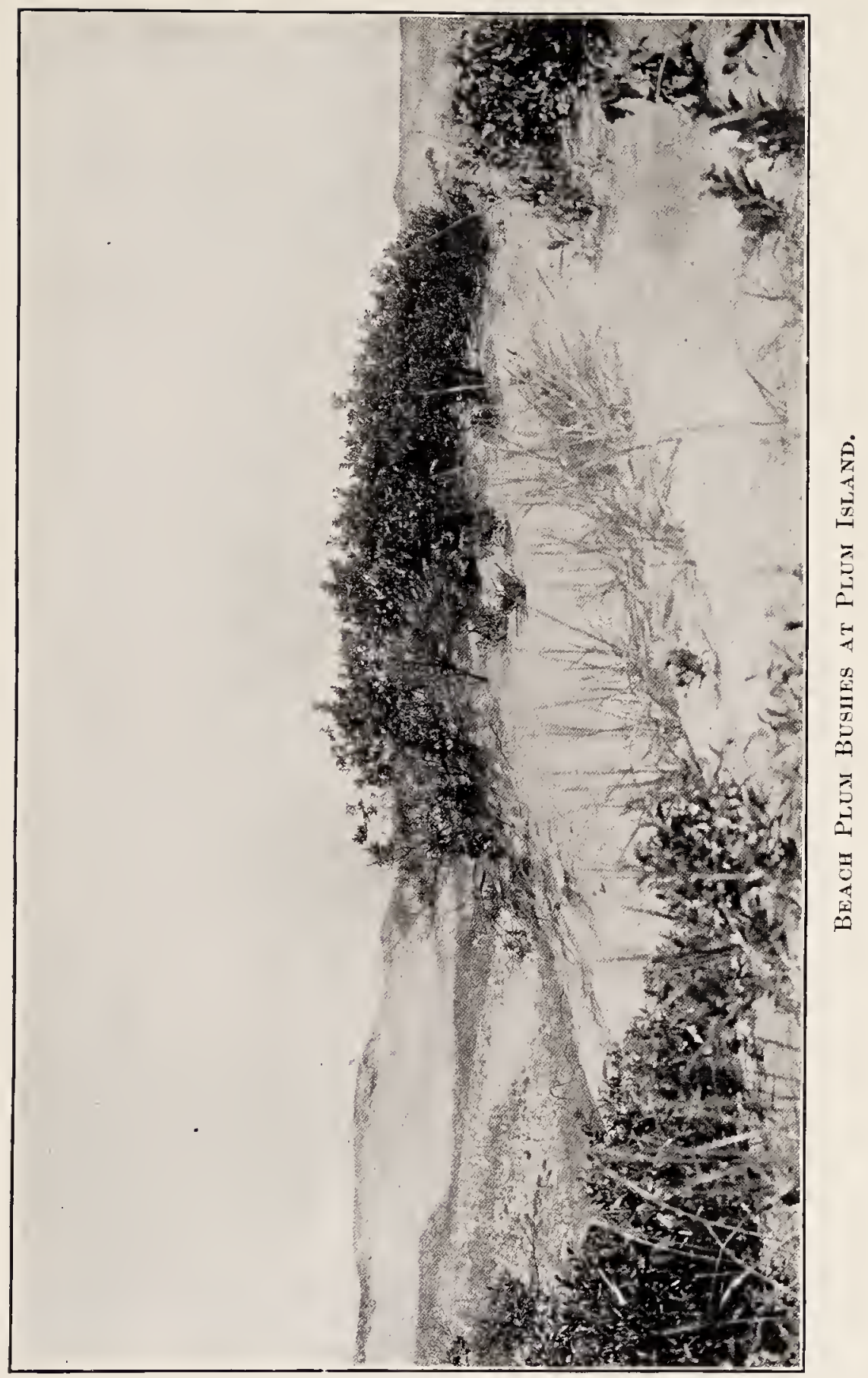





\section{VEGETATION IN THE DUNES}

for making candles which had a delicate greenish brown tint, and exhaled a faintly aromatic odor. The berries were gathered in large quantities and boiled in kettles, and the wax which rose to the surface of the water was skimmed off when cool.

Early in May the bayberry bushes are still gray and wintry and well gleaned of berries, unless perchance they have been long protected by the snow. In the summer they are densely clad in a dress of shimmering green; in the autumn the leaves turn brown and the berries, hitherto inconspicuous by their green color, become gray and hoary. The fruiting branches, with their closely clustered berries, are very beautiful, and stand out the more clearly as they generally drop their leaves earlier than do the barren branches. Throughout the winter the snowy gray of the bayberry clusters is a delight to the eye.

Less abundant than the bayberry among the dunes is its first cousin, the sweet gale, a fragrant bush, but easily distinguished from the bayberry by its dull green leaves with faintly toothed edges. In the early spring, while the bayberry is still gray in its winter sleep, the sweet gale takes on a rich chestnut hue which 


\section{SAND DUNES AND SALT MARSHES}

glows in many a sandy hollow. Its fruit, however, is brown in color and comparatively inconspicuous.

The sumach family is an interesting and beautiful one. Three of the tribe occur in the dunes, and of these the staghorn sumach deserves first place with its thickets of brown, hairy branches in the spring, very suggestive of a stag's antlers in the velvet. Its wealth of dark green foliage in the summer is tropical and palm-like in appearance, and its flame-colored masses of fruit in the autumn are borne aloft like so many torches on the ends of the branches. Its great compound leaves, before they drop, rival the fruit in color. Unlike the staghorn, the poison sumach or dogwood is decidedly uncommon, and is easily distinguished from it by its more delicate leaflets, its reddish leaf stalks and its white fruit. The last of this group in this seashore region, the poison ivy, abounds in every grove and thicket, and there is no more beautiful vine, with its shining green leaves which change to wonderful shades of yellow and red in the fall, and on whose bare winter branches hang clusters of greenish yellow berries.

Perhaps the most beautiful common bush of 82 


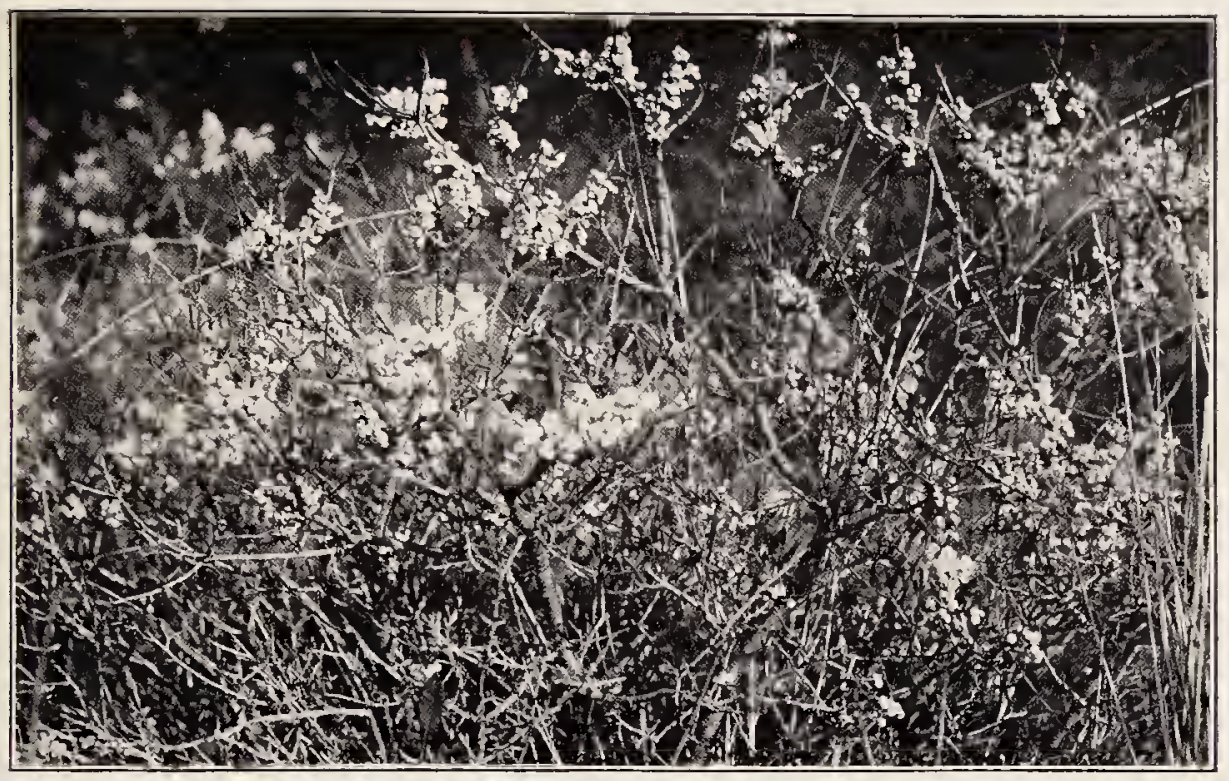

BAYBerry IN WiNTER.

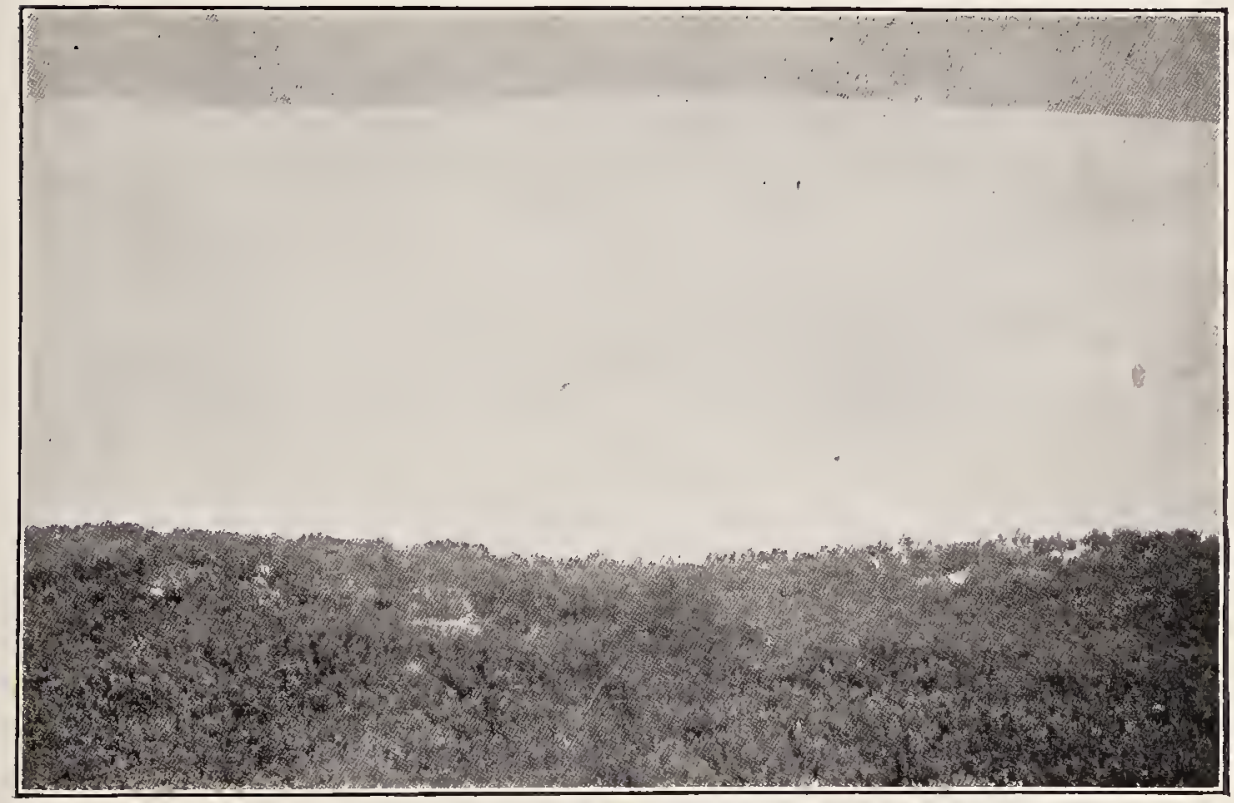

Hudsonia and Advancing Dune. 



\section{VEGETATION IN THE DUNES}

ise dunes is the wild rose, of which there are at least two species. These fragrant single roses seem to take on a deeper crimson in this maritime region than farther inland, and their changing foliage in autumn, and their red hips that stand out in the snow are always attractive. Shad bushes, with their early white blossoms, clumps of meadow-sweet and hardhack with their pink and rose-colored flowers, are common in the dunes, and in one or two places the hardy leather-leaf, named Cassandra, survives the winter with its evergreen leaves, and with flower buds ready to open in the spring. In the fall and winter the black alder or winterberry bushes are aflame with their crowded crimson berries.

There is one bush that grows in two small patches in the dunes whose discovery in bloom is always a delight.

"Rhodora, if the sages ask thee why, This charm is wasted on the earth and sky, Tell them, dear, that if eyes were made for seeing, Then Beauty is its own excuse for being: Why thou wert there, O rival of the rose! I never thought to ask, I never knew:

But, in my simple ignorance, suppose

The self-same Power that brought me there brought you." 


\section{SAND DUNES AND SALT MARSHES}

May the beauty and charm of these flowers long be "wasted on the earth and sky," and not ruthlessly plucked and exterminated from this region!

The trees of the dunes remain to be enumerated. The most important tree is the pitch pine, which forms two groves of several acres in extent, both of which have spread considerably in the last twenty years. Mr. C. J. Maynard tells me that forty years ago not only were there no pines, but no large clumps of bushes to be found in the dunes. One of these pine groves, as we have already seen, is being overwhelmed by a sand wave from the north, but is more than making up for this by its extension to the south. The trees are somewhat stunted and rarely reach a height of more than thirty feet, but their thick groves are a welcome refuge in storms for bird and man alike. I have often cooked my dinner in comfort in the lee of these trees when in the open dunes the wind and sand cut like a knife and the frost was severe.

In addition to the pines there are several thickets of graceful white birches whose height is carefully regulated by that of the encircling dunes, and the wind that sweeps 84 


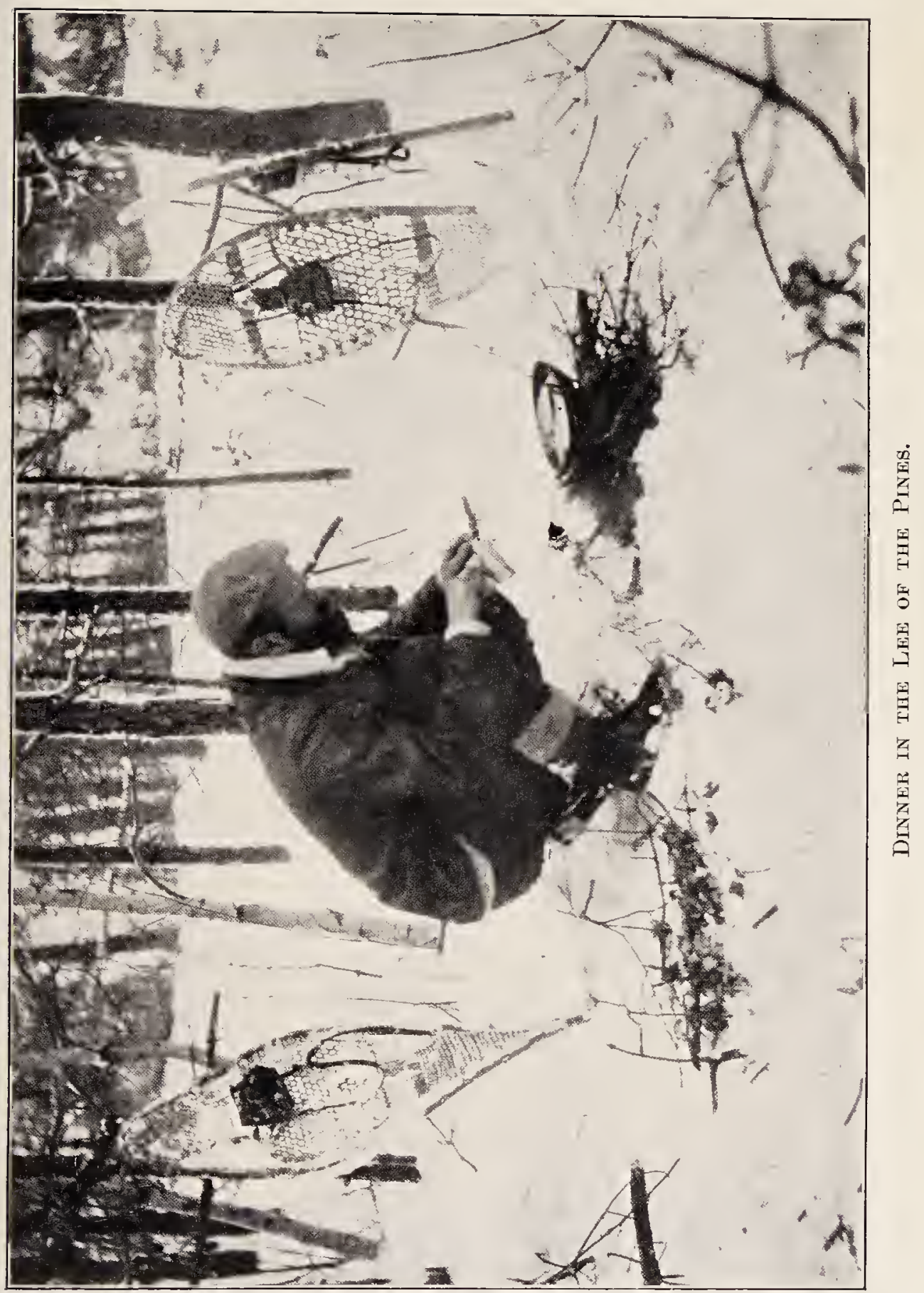





\section{VEGETATION IN THE DUNES}

over them. Thickets and clumps of alders, as well as of aspens and willows, are also common.

The exceptional trees are a few scattered white pines, small and frayed by the wind, some thrifty red cedars, a couple of hunched up hemlocks which bear no resemblance to the stately forest trees, a few red maples, two elms, dwarfed and stunted, that look large only at a distance, and two small clumps of red birches. The red or river birch is common in Texas, the lower Mississippi region and Florida, and extends along the coastal plain to Long Island. From there to Essex County, Massachusetts, is a gap of one hundred and fifteen miles where the tree is absent, but it is common in the lower valley of the Merrimac River and in southern New Hampshire. Professor M. L. Fernald explains this distribution by the former existence of a great highway for plant migration, a sandy shelf that extended out for miles all along the coast from the southern parts of the United States to Newfoundland, a shelf which has largely sunk beneath the waters since the close of the glacial period. 


\section{CHAPTER IV}

\section{LAND BIRDS OF THE DUNES}

"Bird of the wilderness,

Blythesome and cumberless,

Sweet be thy matin o'er moorland and lea!

Emblem of happiness,

Blest is thy dwelling-place -

$O$ to abide in the desert with thee!"

HoGg.

7 HE sandy and desert character of the dunes would at first sight seem to be inimical to numbers or variety in the bird-life there, but the fact that the seacoast is one of the great highways of bird migration renders this region a particularly favored spot for the ornithologist. The thickets of bushes and trees are so limited in extent that the bird population during the migrations is often much crowded together, instead of being spread out over wider areas as in upland country. The sea on the one side and the marsh on the other are each equally inhospitable to 86 


\section{LAND BIRDS OF THE DUNES}

land birds, so that the concentration in the thickets of the dunes is sometimes extreme. Another fact which is of advantage to the bird student is that the trees in the dunes are so low that one can often look down on the tallest of them from the peak of a dune. Besides the great number of migrants, which include practically all the birds that stream along the coast in the spring and fall, and find rest, shelter and food in the dunes, there are a number of interesting birds that spend part or all of the winter there, some of which are rarely found elsewhere than in sand dunes.

The birds that nest in the dunes, and rear their young there, are comparatively few in number and are quickly enumerated. The robin builds in the trees or about the few houses and shanties; the yellow warbler and Maryland yellow-throat are common, and the song sparrow is everywhere in the bushes. Still more common is the Savannah sparrow nesting at the foot of clumps of tall beach grass throughout the dunes and on the edges of the tidal inlets from the marsh. Its song, such as it is, is heard on every hand during the spring and summer,-two chirps, followed by two trills, the first exceedingly high 


\section{SAND DUNES AND SALT MARSHES}

pitched, thin and grasshopper-like, the second rather sweet and musical. The first trill is inaudible to some whose hearing is otherwise good.

A few tree swallows nest in the hollow trees and a few bank swallows in holes in the windcuttings of the dunes. Red-winged blackbirds, bronzed grackles and crows are all common nesters, as well as kingbirds and a few black-billed cuckoos and flickers. There are a few other breeding birds of the dunes, but these are the chief ones.

I doubt not that the hummingbird has raised its young there, for I have occasionally seen it among the dunes, although I have not found its nest. One could not wish a more accurate or charming description of this bird than that of William Wood in his " New England's Prospect." He says: "The Humbird is one of the wonders of the Countrey, being no bigger than a Hornet, yet hath all the dimensions of a Bird, as bill, and wings, with quills, spider-like legges, small clawes: For colour, she is as glorious as the Raine-bow; as she flies, she makes a little humming noise like a Humble-bee: wherefore shee is called the Humbird." 


\section{LAND BIRDS OF THE DUNES}

Crows are worthy of more than passing notice. They are found in the dunes at all seasons of the year, but in far greater numbers in winter than in summer. In summer they are so hard put to it to find trees of sufficient size for their nest that they sometimes build only six feet from the ground. In winter, when the inland country is frost-bound in ice and snow, crows resort to the seashore in great numbers and live on the varied diet which the beaches and the marshes afford. The character of this diet is well shown in the ejected pellets described in the chapter on tracks and tracking. The nights are spent in roosts in the thickets in the dunes, but chiefly in the pine woods of Cape Ann and Essex. In the morning one may see the crows flying out from their night roosts, starting from half an hour to an hour before sunrise. They fly singly and in groups of from ten to thirty, and by sunrise all are about the day's business, scattered to feed along the beaches and throughout the marshes of Ipswich, Essex and Rowley. These early morning flights are less direct than are the return flights at night, for the birds are evidently hungry and on the lookout for food. 


\section{SAND DUNES AND SALT MARSHES}

Most of these crows that spend the winter at the seashore go elsewhere in summer, and on pleasant days in the early spring I have seen the departure of some of them. On a March morning, just as the sun came from behind some clouds, a flock of thirty or forty crows rose from the dunes, circled irregularly upwards until they were mere specks in the sky, when they all started off in a direct course for the northeast. An hour later a flock of twenty-seven rose from the marsh and did likewise. Crows are social beings, and even in the midst of the breeding season flocks of fifteen or twenty adults often feed together.

The crow is commonly accredited with only one note,-the notorious caw. That he possesses this note, no one will deny, but he also has numerous other notes, and indeed his vocabulary is an extensive one. As a songster, however, he is not a success. Conversational notes and tones of every description issue from his throat, and nothing is more entertaining than the varied notes exchanged by a family of these birds, now low and confidential, sometimes pleasing or slightly melodious, again raucous and scolding, even torrential in their abusiveness. The notes are so 


\section{LAND BIRDS OF THE DUNES}

constantly changing in inflection that one feels sure that each has its meaning. A common spring note is a hoarse rattling, sometimes likened to the gritting of teeth; at other times the birds laugh a loud $h a, h a, h a$, while a nasal taunting nev-ah, nev-ah and $a h$, ah, expressive of great relief, as well as wailing cries, are common. Sir John Richardson called this bird "the barking-crow," and old Chaucer spoke of " the crow with vois of care."

A still more peculiar note I have heard from the mouth of a crow. This was at sunrise on a frosty December day close to my house at Ipswich. Near my bedroom window sat a crow that from time to time emitted two low clucks, followed by a single booming sound, the whole a phrase of unknown meaning, which I wrote down thus: cluck-cluck, whoooo. Between these phrases the crow cawed in an orthodox manner.

If one should attempt to describe all the birds that pass through the dunes in the spring and fall, he would be obliged to write a general book on ornithology. An illustration of the abundance and variety of the migrants is the fact that on a day in May my friend, Mr. Ralph Hoffmann, saw within the 


\section{SAND DUNES AND SALT MARSHES}

space of three minutes eleven different members of the warbler family pass through a single tree in the dunes. Besides these I have myself seen ten other species, or a total of twentyone warblers in the dunes, as follows: black and white, Nashville, parula, yellow, blackthroated blue, myrtle, magnolia, chestnutsided, bay-breasted, black-poll, Blackburnian, black-throated green, pine, yellow palm, prairie, Wilson's, and Canadian warblers, and oven-bird, water-thrush, Maryland yellowthroat and redstart.

It is difficult to describe the feelings of a bird lover on a perfect May day in such an environment as these Ipswich dunes, especially if he has come from a long confinement in the city.

"To one who has been long in city pent,

'Tis very sweet to gaze into the fair

And open face of heaven, to breath a prayer

Full in the smile of the blue firmament."

One's every sense is appealed to, and every sense must be on the alert that he may enjoy the full beauty of the scene, recognize all his bird and flower friends, and distinguish each note and song and perfume. While he is 92 


\section{LAND BIRDS OF THE DUNES}

endeavoring to catch a glimpse of an elusive warbler that persists in dodging about on the far side of a bush or tree, he distinguishes half a dozen songs or call notes and catches glimpses of as many more birds. It is a great satisfaction for him to recognize a call note which perhaps he last heard two or three years before in Cape Breton or Labrador, and, after as skilful stalking as that of any hunter, bring the bird plainly into the field of his glasses and thus confirm the diagnosis.

But it is not merely the rare birds that gladden the heart of the bird-lover in these wonderful spring days; it is the meeting with old friends-birds that return with each spring and sing their familiar songs - that satisfies so deeply his soul. Have I not felt thrills run up and down my back when the first brown thrasher of the season has mounted a swinging branch of barberry and carolled forth his jolly song, so well emphasized by repetitions of each theme, and have I not almost wept for joy on hearing for the first time " Hear me, Saint Theresa" coming from the pines, for I knew, although I saw him not, that the black-throated green warbler had arrived from the south again. 


\section{SAND DUNES AND SALT MARSHES}

The older one grows the more he appreciates these days, and each successive spring appears more divinely wonderful, more of a miracle than he has ever thought it in the past. One can but hope that the same joy and the same enthusiasm for this glorious feast spread by nature's hands will continue for all of us for many years to come.

"Give me the man, however old and staid,

Or worn with sorrow and perplexity,

Who, when he walks in sunshine or in shade,

By woodland bowers, or bare beach of the sea,

O'er hill-tops, or in valleys green, with me,

Throws off his age and gambols like a child,

And finds a boyish pleasure in the wild,

Rejuvenescent on the flowery lea:

Him shall the years pass lightly as he goes:

The kindly wisdom gathered in the fields

Shall be his antidote to worldly woes:

And the o'erflowing joy that nature yields

To her true lovers, shall his heart enclose,

And blunt the shafts of care like iron shields."

There is one migrant land bird that is rarely seen in the spring, but is very abundant in the dunes and about the marshes in the fall from the middle of September to the end of the first week in November. This is the pipit, 



\section{LAND BIRDS OF THE DUNES}

sometimes called titlark, a slender bird dressed in delicate shades of buff and gray. While with us it utters nothing but its call notes-seet-see-whit-but in its summer home in Labrador it revels in a flight song. This is a simple refrain, a vibratory che-whee, which is rapidly repeated both as the bird flies up into the heights and as he descends to earth.

At Ipswich pipits appear in flocks in the fall, and walk about the sand dunes with dovelike motions of the head and neck. They frequently wag their tails up and down, a nervous trick which makes their recognition in the field an easy one. It is rare that they alight anywhere but on the ground, yet I have oceasionally seen them on old stumps and fence rails, and a very few times in the branches of trees.

Swallows are at some seasons so abundant in the dunes that they deserve a separate chapter and will be considered later.

The most characteristic birds of the sand dunes, however, are the migrants from the north that spend the whole or a greater part of the winter. The myrtle warbler is one of these and is considered in some detail in the twelfth chapter. It is the only warbler that 95 . 


\section{SAND DUNES AND SALT MARSHES}

spends the winter so far north, and one has an opportunity to watch it changing by the spring molt to the brilliant summer dress. The process begins as early as the last of March, and the birds sing before the molt is finished. As early as April 7th, I have heard a myrtle warbler, who was in extensive molt and very shabby, sing a feeble warbling song.

Such northern birds as the two species of crossbills, the pine grosbeak, the redpolls and the pine finch, that come here only when the food supply fails them in the north, or perhaps when the wanderlust strikes them, are at times familiar birds in the dune groves. They are always interesting, and much could be said of their charming ways. All are but little afraid of man, for they have come from northern wildernesses where he does not disturb them. I believe it was Buffon who said that the crossbills were deformed by the severe climate in which they lived, but if one has watched them extracting the seeds from a pine cone, he realizes what a perfect instrument for that purpose their " deformed" bill is. They often hang from the branches and the cones by bill and feet like parrots, and their red and green and yellow plumage en96 


\section{LAND BIRDS OF THE DUNES}

hances the illusion. Sometimes one breaks off a cone and flies with it in its bill to a convenient perch, where it holds the cone with its foot while extracting the seeds.

'With their small and ordinary bills the little pine finches are able to accomplish the same thing. A flock of these birds hanging to the cones and branches is a pretty sight. The seeds are deftly extracted, the meat is eaten and the dry wings left to flutter down to the ground.

All of these northern birds have distinct and characteristic call notes, whose recognition in the field is a great pleasure. As a flock of crossbills passes overhead in undulatory flight, a shower of notes, sounding like the skipping of stones on the ice, tells us that they are red crossbills, while if the notes have a rattling or chinking character, we know that the birds are the white-winged species.

One is rarely treated in Essex County to the spring song of these birds, but they may be heard on the northern breeding grounds. Of all their songs nothing exceeds in beauty the joyous carolling of the white-winged crossbill in the height of his courtship. Perched on the top of a spruce, he begins his lay, but 


\section{SAND DUNES AND SALT MARSHES}

its vehemence is such that it generally lifts him up into the air, and as he flies about slowly, he pours forth his soul. The song is a wonderful succession of trills, now low and deep, now swelling into a loud all-pervading melody which resembles that of the canarybird; now it dies away to a low warbling, and again bursts out into a joyous trill which takes the bird exhausted to his perch.

The song of this bird, as of many others in this country, is worthy of the poet's pen. Many people suppose that our song birds are few and inferior as compared with those in England, with whose ways and songs they are familiar from poems and from references in literature. A songster, no matter how commonplace, that has been praised by Chaucer and Shakespeare and Tennyson, has a prestige that our unheralded birds lack, be their voices ever so fine. Some day they will come into their own and be as much appreciated as their relatives over the water.

Entirely different from these song birds are two species of owls occasionally seen in the dunes. One of these, the short-eared owl, a bird widely distributed throughout the world, is rare in winter but not uncommon during 98 


\section{LAND BIRDS OF THE DUNES}

the migrations. I have seen it but seldom, however, during the last half dozen years. Colored like the sand and the leafless bushes, it is rarely noticed until it mounts into the air and flaps, and sails away.

I have thrice been so fortunate as to see a snowy owl in the Ipswich dunes. On the first occasion I had nearly walked by the bird, as it sat in its characteristic attitude, bent at an angle of forty-five degrees, when I discovered that the gray stump about seventy yards away was a snowy owl. His eyes were narrow slits more than twice as long as broad, but he kept one of them on me, and he occasionally turned his head so that one eye relieved the other. After watching him in return for fifteen minutes I relaxed my "frozen " posture, and dropping to the ground, endeavored to stalk him. Notwithstanding all my care, he took alarm at once, and, spreading his great wings and throwing his feathered feet out behind, he flew off with broad wing sweeps.

Both of these owls are well able to see by day in the broad glare of the sun, and are not birds of the night alone. Both are great mousers, and as such are of service to agriculture. It is recorded that in the year 1580 


\section{SAND DUNES AND SALT MARSHES}

there was a "sore plague of strange mice" in Essex, England, but that owls thronged from all sides and helped to exterminate the pests. Occasionally these owls vary their diet with a bird, and I once started a short-eared owl in the dunes who had been feasting on a robin. A snowy owl in my collection smells strongly of skunk. But the odor of skunk on one's clothes does not necessarily mean that one has eaten the animal!

One of the characteristic bird notes heard in the dunes in the fall is the sibilant squeaky note of the horned lark. This northern bird takes the place of the prairie horned lark which in smaller numbers spends the summers. Indeed it begins to come during the last of September before its smaller relative is gone, and in November and December flocks of fifty or a hundred are not uncommon in the dunes. Toward the end of January and in February and early March comparatively few are to be found, while in the latter half of March they again increase in numbers, but are never so common as in the fall. Early in April the last survivors of the winter leave for the north.

The horned lark is a handsomely marked 100 


\section{LAND BIRDS OF THE DUNES}

bird with its black patches below the eyes and on the breast, and its yellow throat and eye lines. At times, especially in the spring, the long black feathers extending from the forehead above the eyes appear to stand out as horns. It is a swift walker and picks at the seeds of weeds and grasses from the ground, never alighting on them as do longspurs, Ipswich sparrows and snow buntings, its three other companions of the winter. It sometimes flies up from the ground, seizing the seeds on the tall grass or weed-stalks, at the same time shaking many off on to the ground, which it picks up before repeating the process.

It is a persistent fighter or extremely playful, and is constantly engaged in chasing its fellows. I have seen two face each other for a moment, with heads down like fighting cocks, the next instant twisting and turning in the air, one in hot pursuit of the other.

In a rough turf field horned larks are particularly difficult to see, as they are apt to squat in depressions behind stones or sods, and their colors harmonize well with the ground. It is probable that they spend the night in these situations, for in crossing a field, one dark November night, my dog 


\section{SAND DUNES AND SALT MARSHES}

started up two or three horned larks that flew off emitting their characteristic notes.

The flight song of the horned lark I have heard in Labrador. 'The bird springs up from the ground and mounts silently into the air, rising in irregular circles or almost vertically until it appears but a little speck in the sky, or perchance is lost to sight in the scudding fog. Then it soars and pours forth in great ecstasy a song that begins with one or two notes followed by a series of squeaks, high notes and fine trills, suggestive at times of distant sleigh bells and again of un-oiled gates. The song finished, the bird flaps its wings a few times, closes them and then sails again, and again repeats its song. One bird I timed remained in the air three minutes, during which it repeated its song thirty-two times. When the bird has finished singing it silently and very rapidly plunges back to earth. The performance is well worth hearing and, although not highly musical, is very pleasing and decidedly spectacular.

The snow bunting is indeed a bird of the snows, and as a flock of these white birds whirl about in their fitful manner, now rising, now falling, as if blown by gusts of wind, they are 102 


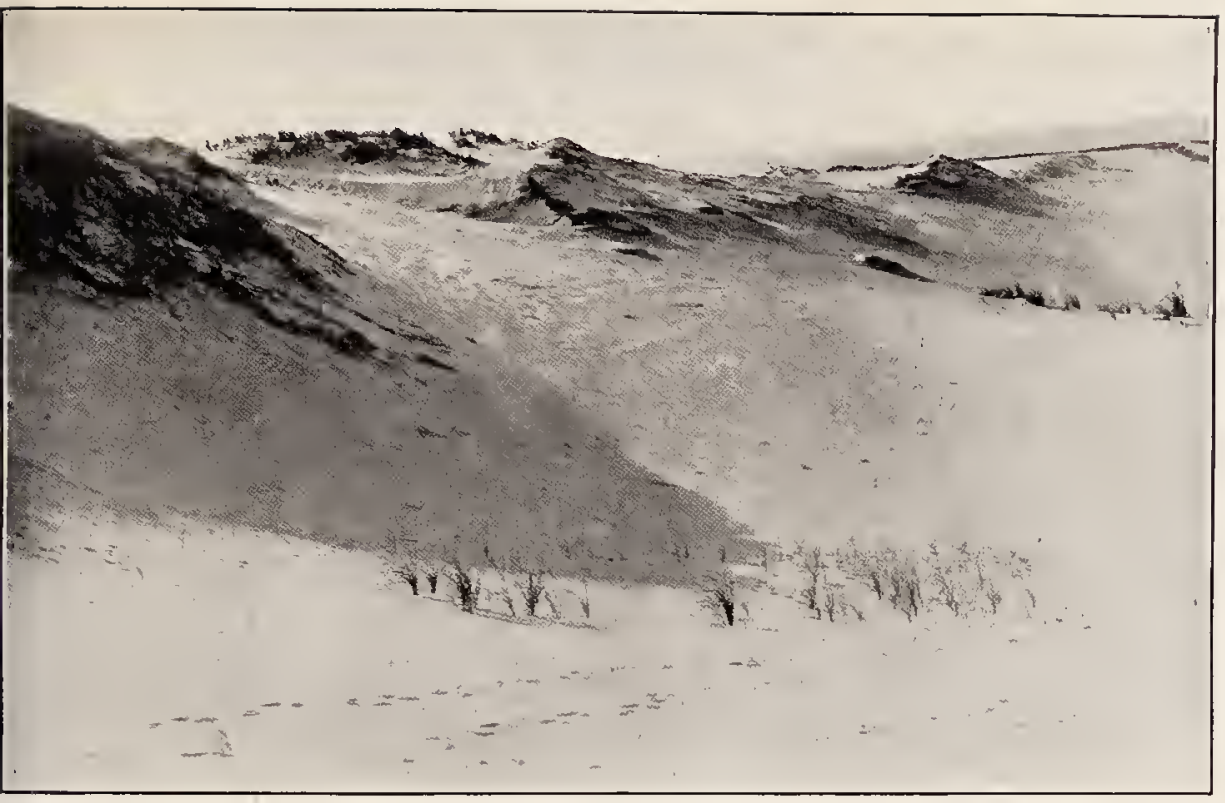

The Dynes in Sumater.

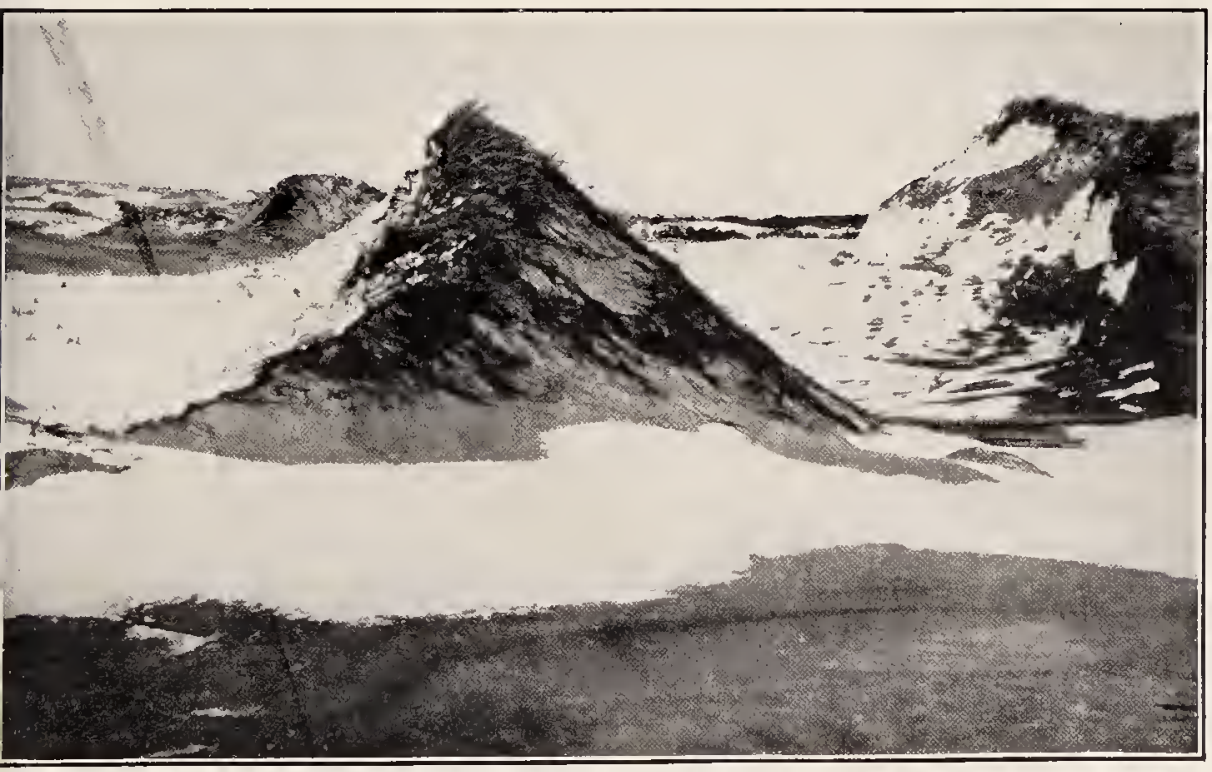

THE DUNES IY WINTER. 



\section{LAND BIRDS OF THE DUNES}

very suggestive of a snow flurry. On their arrival in late October their bodies are largely "veiled " in chestnut brown, for many of the feathers look as if they had been dipped in a brown wash. As the winter season advances and spring approaches, the brown tips are more and more frayed and worn away, and without any molt the birds become in the spring beautifully black and white. The nuptial dress, therefore, is present in the fall but is concealed beneath a brown duster. It is thought by some that the brilliant spring dress of male birds is due to the exuberant life and passion of the male at that season, but in the case of the snow bunting, as well as of the Lapland longspur, to be presently described, and of a number of other birds, the nuptial dress is in reality produced at the end of the previous summer, when the passions are at their lowest ebb.

The call notes of the snow bunting are sweet and melodious whistles, interspersed with rippling trills, but changed to rasping tzees when the birds chase each other. Early in April, before they leave us, they indulge at times in low warbling songs, suggestive of those of the purple finch, and when a flock of a hundred 


\section{SAND DUNES AND SALT MARSHES}

or more are singing together the effect is very pleasing. This song is doubtless as inferior to the songs heard on the breeding grounds, as that of the fox sparrow heard here is inferior to the wonderful bursts of melody it pours forth in more northern regions in the presence of its nesting mate.

The Lapland longspur has long spur-like hind claws, and breeds throughout the arctic parts of the northern hemisphere, including Lapland. From these two facts the bird takes its name. It is not as common as the snow bunting, but is sometimes found in flocks of from twenty-five to fifty. It often associates with both the snow bunting and the horned lark, while the Ipswich sparrow is occasionally added to the company. The Lapland longspur arrives from the north early in October and is common in December and often throughout January. In February, March and April it is rare, but more have been seen in these spring months of late years than ever before. Although fluctuations of this sort in bird-life occur, it is possible that the increase is only apparent, and is due to the growing number of acute bird students.

Sir John Richardson wrote that the Indians 104 


\section{LAND BIRDS OF THE DUNES}

on the Dease River, near the Arctic Ocean, believed that the Lapland longspur " availed itself of the strength of wing of the Hutchins Goose, and nestled among its feathers during its flight. When a goose is shot, they often see the small bird flying from it." And he naïvely adds: "Neither Mr. Rae nor I noticed such an occurrence, nor did I obtain a confirmation of it from the personal observation of any of the gentlemen resident in the country, but it is generally affirmed by the Indians."

In the fall Lapland longspurs are inconspicuous and sparrow-like, especially the females and young, but in the latter part of the winter and spring the male acquires a jet black bib, by the simple process of wearing off the gray veiling tips of the feathers. This can be shown by a series of specimens extending from the fall to the spring, and it is no more wonderful than the process which any one may watch in our city streets - in fact it is exactly similar. The adult male English sparrow in the fall has a gray shirt-front with scarcely a suspicion of the black bib or shield that forms his chief adornment in the spring. It is present, however, but concealed by the veil which gradu- 


\section{SAND DUNES AND SALT MARSHES}

ally wears away and reveals his charms. Not only is the black shield revealed in the English sparrow by this process of wear, but the black and chestnut markings on the back and neck become more distinct, while the white of the sides of the throat and abdomen becomes whiter. How few there are who have any idea of these changes in the common English sparrow, yet they are constantly going on before our eyes!

The call notes of the longspur are very similar to those of the snow bunting, except that they are slightly sibilant, and that a hoarse rattle or chirr replaces the pleasing trill of the bunting.

The last and most interesting of this group of winter birds is the Ipswich sparrow, a bird rarely found outside of sand dune regions. Breeding on Sable Island off Nova Scotia, it spreads along the coast in winter from Nova Scotia to Georgia, wherever sand dunes are found. Its relationship to the Savannah sparrow is interesting and is discussed in the last chapter of this book.

On December 4, 1868, Mr. C. J. Maynard shot at Ipswich one of these birds. It was at first thought by Professor Baird to be the 106 


\section{LAND BIRDS OF THE DUNES}

rare Baird's sparrow, but in 1870, after two more specimens had been taken, the fact was discovered that this was a bird entirely new to science. Mr. Maynard called it the large barren-ground sparrow, but the name Ipswich sparrow has always clung to it, and the former name has been forgotten. As soon as the bird had been pointed out by Mr. Maynard, ornithologists began to discover it all along the sandy coasts. It is common at Ipswich during November and December, very rare during January and February, but not uncommon during the latter part of March and the first part of April. My extreme dates are October 11th and April 12th.

It is natural that ornithologists, after discovering the winter haunts, should wish to know the breeding home of this bird. The presence in the National Museum at Washington of a series of eggs from Sable Island, Nova Scotia, labelled "Savannah sparrow," but somewhat larger than the eggs of that bird, strongly suggested the possibility that they might belong to the nearly related but larger Ipswich sparrow. To settle this point, Dr. Jonathan Dwight, Jr., made an ornithological pilgrimage to this island in May, 1894, 


\section{SAND DUNES AND SALT MARSHES}

and discovered the Ipswich sparrow breeding there in numbers. Indeed the bird has never been found breeding anywhere else, although diligent search has been made.

The first descriptions of the Ipswich sparrow stated that it was very wild, that it rose at a considerable distance, flew wildly and far and at once concealed itself on alighting, so that collectors were obliged to shoot the bird on the wing. This method of pursuit was not very favorable for observation. I must confess that my first Ipswich sparrow was found and shot in this manner, but I very soon learned that if treated properly the bird could be studied at close range. In fact I have often watched them within a few yards for long periods of time, and have therefore been able to note every peculiarity. The beach, where the view is unobstructed by grass, is the best place for the study of Ipswich sparrows. It is moreover one of their favorite resorts, as they are fond of the small flies that abound on the seaweed and thatch thrown up there.

Ipswich sparrows very rarely hop; they almost invariably walk or run. In walking the head and shoulders move back and forth in a charmingly dove-like manner, while in 108 


\section{LAND BIRDS OF THE DUNES}

running the head is held low and the bird disappears behind a clump of grass or a dune in exceedingly quick time. As a catcher of torpid flies in the sea-wrack they are fairly expert, and they occasionally jump into the air after their game, usually without success, however, as far as I have observed. Like many other sparrows they occasionally scratch for food, and they do it in such a vigorous manner that they fairly make the litter fly. This sparlow-scratching is done in a different manner from the scratching of barn-yard fowls. The latter scratch with one foot and then the other alternately, while sparrows jump forward and scratch with both feet together, as if they were on springs. Why they do not fall forward on their heads, I never could understand.

The call note of the Ipswich sparrow is a sharp tsip, to my ears exactly like that of the Savannah sparrow. They rarely sing while with us, but Dr. Dwight says the song on their breeding grounds is like that of the Savannah sparrow but " more polished and tuneful." I have been so fortunate as to hear the Ipswich sparrow sing once on an April day at Ipswich, but unfortunately the song was rather imper- 


\section{SAND DUNES AND SALT MARSHES}

fect, certainly not a "polished" one. Birds rarely sing their best away from their breeding grounds.

In appearance the Ipswich sparrow resembles its cousin, the Savannah sparrow, but is larger and is protectively colored for a sandy habitat. One does not realize how gray or sandy-colored it is until one is so fortunate as to come across it in the marsh. The contrast with the color of the background then emphasizes the true color of the bird so that it seems almost white. 


\section{CHAPTER V}

SWALLOW ROOSTS AND SWALLOW MIGRATION

"Nature's licensed vagabond, the swallow."

- TENNYSON.

W WALLOWS begin to gather near the $\checkmark$ shore at Ipswich, as well as elsewhere on our coast, as early as the first of July, and their numbers rapidly increase from day to day. At the end of that month and during August and early September, great multitudes of these interesting birds are to be found in the neighborhood of the sea. In these flocks all four of our common species occur, but by far the most abundant is the tree swallow. Next in numbers comes the barn swallow, and next the bank swallow, although the latter is less common in Ipswich than the eave swallow, which appears to be a rather more exclusive bird, and one that is more apt to keep by itself than to mingle in the large mixed flocks. 


\section{SAND DUNES AND SALT MARSHES}

From the great numbers of swallows that congregate here in the fall it is evident that many must come from a distance, for there are more than the immediate country would support during the nesting season. It is their annual excursion to the seashore, and although they gather about the neighboring roadsides, pastures and marshes, their favorite resorts are the dunes and upper beaches. Although some of these birds migrate south early in the season, the majority remain together for days or even weeks before starting for their winter homes; yet it is possible that some are constantly leaving, and their places are so quickly taken by others that we do not notice any diminution in their numbers.

Although many of the swallows scatter far and wide in the search for food, yet such is the social disposition of these birds that great flocks are commonly to be found during July, August and early September, even at midday in various of their favorite haunts. Perhaps the most familiar of these haunts, and certainly the most conspicuous to the passer-by, is the roadside. Here they congregate and line fence rails and telegraph wires. Before the extension of the wires to the beach road 


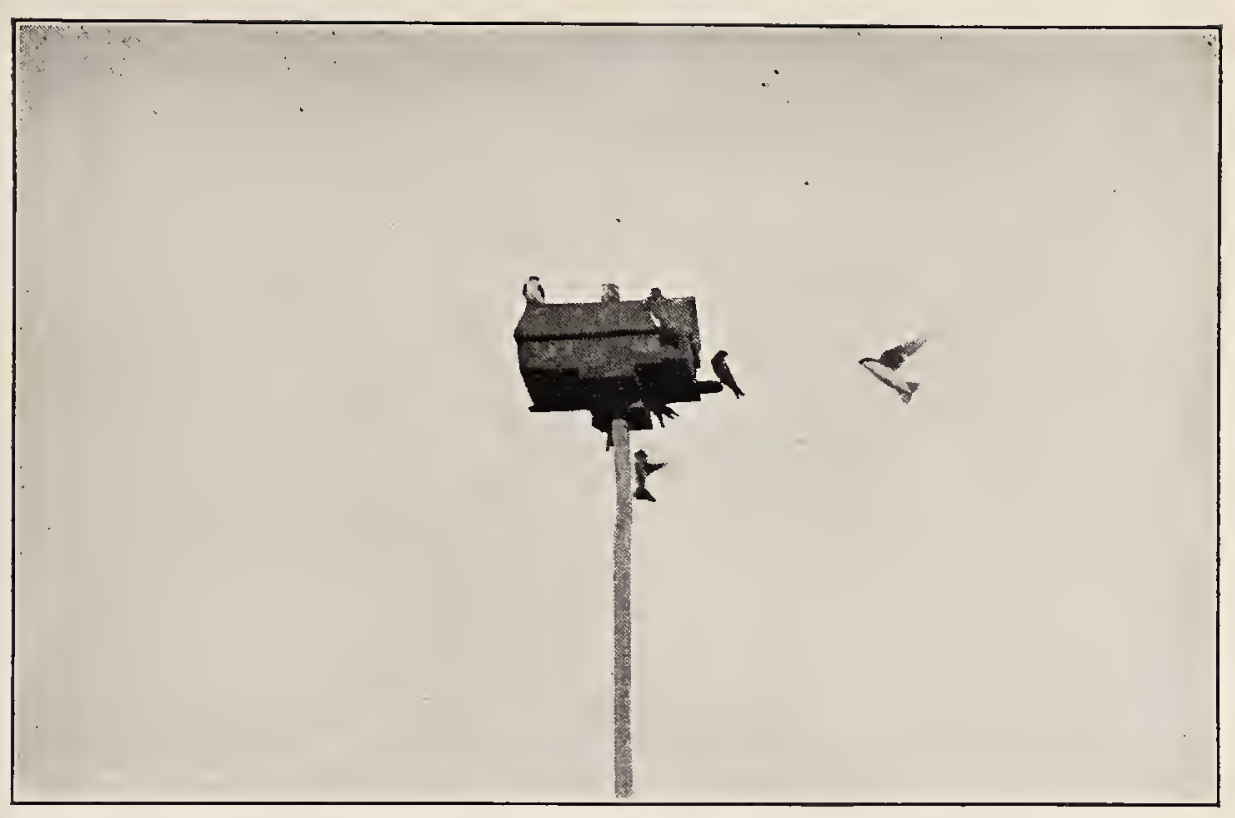

Tree Swallows Investigating A Birdhouse.

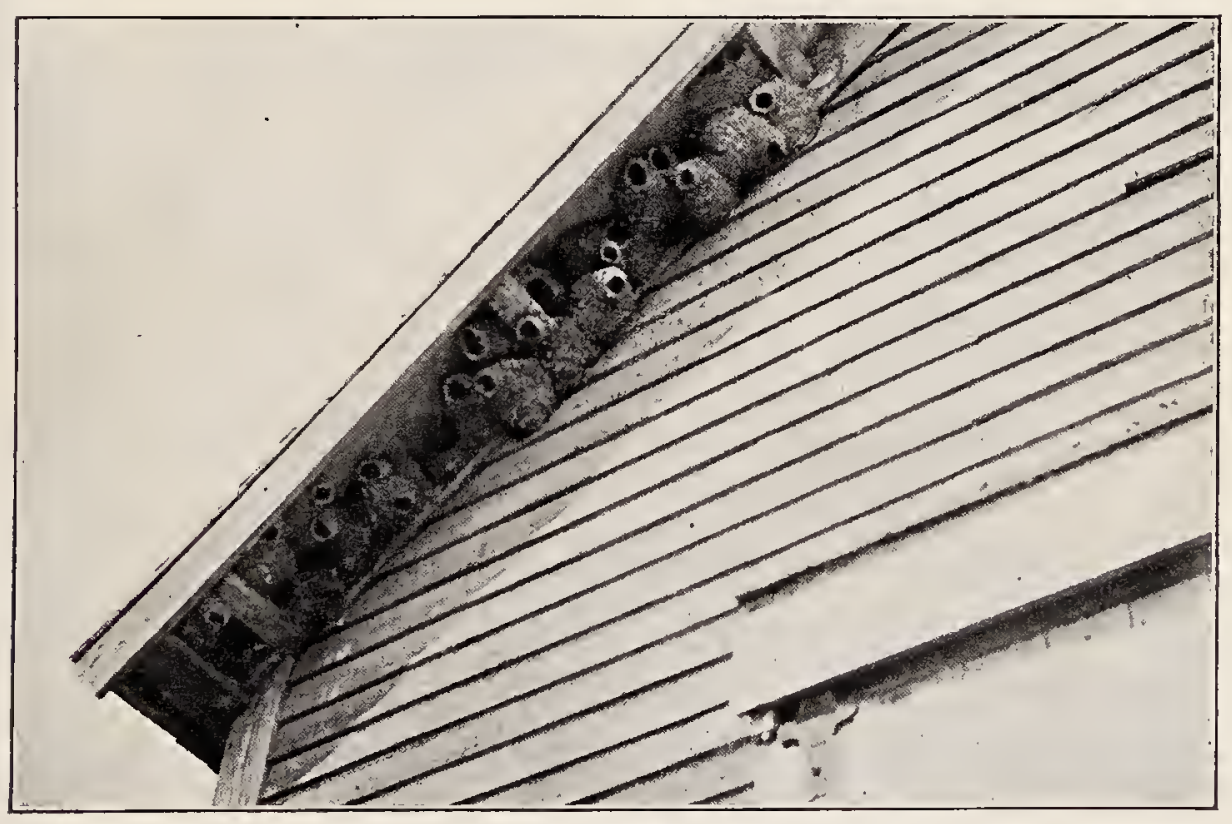

Nests of Eave Swallows on Ax Old Bary. 



\section{SWALLOW ROOSTS AND MIGRATION}

at Ipswich, the swallows often clustered on the fence rails, but since the erection of these "way-side crucifixes," as Frank Bolles called telegraph poles, the lowlier perches have been forsaken.

One may see lines of these birds stretching, with but few gaps, on a couple of wires for a mile. Such congregations number several thousand, and all four species may be seen sitting shoulder to shoulder in the most friendly and democratic manner. At times, especially on marsh roads, where there are neither retaining fences nor overhead wires, the swallows cover the ground itself in patches, taking flight reluctantly as the wayfarer advances upon them.

Another favorite resting place by day is in the salt marshes, where the birds cover every available projection such as fence posts, staddles, gunner's blinds and stranded branches of trees.

Swallows are certainly fond of the water and delight to gather about ponds near the seashore. I have seen as many as two thousand in such a situation in Ipswich. The great majority of these were tree swallows, but here and there a barn swallow and a diminutive 


\section{SAND DUNES AND SALT MARSHES}

bank swallow were to be seen. They were constantly alighting on the bushes, fence wires, and rails, particularly on those that were over the water. Every few moments, with a loud whirring noise from their many wings, they would rise and wheel about in bands, showing first dark and then white, as they turned alternately their backs and their breasts to the observer. Again they would distribute themselves irregularly over the sky, and a little later they would throw themselves at the water with such violence that the surface would be covered with little splashes, as if a bombardment were in progress.

Such exhibitions as this display not only the social and gregarious characteristics of swallows, but also the love of what appears to deserve the name of play. It has been said, as a reproach to their intelligence, that birds do not play when young as do the young of mammals, but the evolutions I have just described seem to show a spirit of enjoyment or play in flight, the natural exercise of birds, just as do spurts of running, or wrestling or butting contests in mammals.

Another interesting trait of these flocking birds is their.habit of inspecting holes in posts 


\section{SWALLOW ROOSTS AND MIGRATION}

and trees, and bird-houses that come in their way, as well as of collecting feathers in their bills as they fly. This autumnal revival of the nesting instincts is an interesting trait, and appears to be a common one in birds. Examples of this are the autumnal revival of song, notably in the meadow-lark, bluebird, song and Savannah sparrows, as well as in the barn and tree swallows; of the inspection of nesting localities by bluebirds and phoebes as well as by tree swallows; and of the courtship actions of grouse, sandpipers, plovers and ducks.

Among the apple orchards near the coast at Ipswich are to be found many ancient trees, picturesque veterans, partly killed by the struggles with many winters, storm-beaten and time-worn, yet surprisingly full of vigor in their living branches, as shown by their wealth of blossoms in the spring and of apples in the fall. Among the dead branches of these old trees swallows love to congregate; here they proclaim their presence, even in their absence, by the numerous white droppings that spot the dead branches; here they roost for the night in great numbers. From these dead tree-tops they arise in the early morning with 


\section{SAND DUNES AND SALT MARSHES}

the whirring of many wings, and betake themselves to the roofs of neighboring barns, where they sun themselves, preen their feathers and gossip with one another. These roosts among the orchards may be frequented for many days or weeks before all the birds disappear for the south.

The sand dunes and beaches, however, are the most popular resort of this interesting group of birds. Here they alight on the beach itself, on the smooth expanses in the dunes, or among the bayberry bushes, where the tree swallows gorge themselves with the waxy berries. I once found forty-one of these large berries in the small alimentary tract of a tree swallow. As far as I know this is the only species of swallow that enjoys such an unusual diet, for insects are, of course, the swallow's favorite prey.

"The swalow, mortrer of the flyes smale, That maken hony of floures fresshe of hewe."

In a thicket of birches among the dunes just to the south of my camp a multitude of swallows spend the nights in the latter part of the summer, and they are interesting neighbors. On one August evening I watched them from 


\section{SWALLOW ROOSTS AND MIGRATION}

the top of a dune. They began to arrive about six o'clock, and the majority came from the west,--from the region of the setting sun,and flew in a continuous sheet, perhaps a third of a mile wide, skimming for the most part close to the sand, but mounting occasionally high into the sky. As the birds sped by me, they often flew within a few feet or inches, and at times barely grazed the sand. Tree swallows were in the majority, while barn swallows formed perhaps a fourth part of the whole, and there were a few bank but no eave swallows. The characteristic notes of the three species could be heard from time to time, but the birds were for the most part silent, although occasionally a barn swallow would break forth into his always delightful song. The flight was an irregular and wavering one, but the multitudes were intent on their goal, wearied, no doubt, by the day's work and play. Occasionally two would stop in their onward career, playfully to attack each other in mid-air, and at times, for no apparent reason but as the impulse seized them, a sudden upward or even retrograde movement of all the birds would occur. The sun set at five minutes of seven, but the birds 


\section{SAND DUNES AND SALT MARSHES}

still poured by in the gathering dusk, while the air to the north and west appeared filled with black forms against the luminous yellow haze made by the rays of the departed sun. At ten minutes past seven, already dusk, the birds were pressing on in undiminished numbers. Two minutes later they suddenly stopped coming, with the exception of a few stragglers, while a great mass of whirling, twittering birds could be seen over the birch thicket to the south. A minute later, at thirteen minutes after seven, another army of birds was flying south, but the movement ceased at a quarter past seven, although a few belated ones straggled by in the darkness.

At half-past seven I ventured to investigate the roost, which I found to be somewhat over an acre in extent and to consist of small birch trees about fifteen feet high, closely crowded together. The blackness of the undergrowth of ferns was relieved by the numerous white droppings of the roosting birds. In the darkness not a swallow could be seen amid the thick foliage, but a constant conversational twittering revealed their presence. As I entered the grove the noise became greater, and a number of birds above my head took flight. 


\section{SWALLOW ROOSTS AND MIGRATION}

I shook a tree and a frightened mass of swallows flew out with whirring wings. The disturbance, however, was local and soon quieted when I had beaten a hasty retreat.

The morning flight from this roost was certainly an interesting performance. I slept that night on the top of a pointed dune a short distance to the west of the swallows. About four o'clock I heard a few swallows going over, and ten minutes later a large number of these birds sprang suddenly into the clear, cool morning air that was already faintly glowing with the light of the coming sun. Hither and yon they flew in the exuberance of their joy of living, describing irregular curves and partial circles, fluttering their wings rapidly and bursting out into song which proclaimed their identity. The song was that of the barn swallow, and the combined effect of the great multitude of singers was delightful in the extreme. All appeared to be barn swallows, although in the imperfect light identification by sight was difficult. In a few minutes the joyful birds dispersed. Many, still singing, flew over my sandy couch high in the air towards the west, and soon all were gone. The song of the barn swallow 


\section{SAND DUNES AND SALT MARSHES}

is one of the most delightful of our bird songs, yet it is but little known.

For nearly ten minutes only a few scattered swallows were to be seen, when suddenly a great whirring of wings was heard, and the simple song of the tree swallow, poured from a multitude of throats, burst upon my ear. The effect was a pleasing musical jingling, that seemed to shower down from the sky, as many hundreds, perhaps thousands, of tree swallows rose in the air. As they went north and west they flew for the most part lower than the previous band of barn swallows, that now seemed small in comparison. They did not skim close to the cold sand, however, as at night, but were perhaps one hundred feet up. At a quarter of five a mixed flock of about a hundred swallows flew over me as I lay on my dune-top. In this group barn, tree, and bank swallows could all be distinguished. The sun rose out of the sea at eight minutes of five. Another day of hunting and sport!

The southward migration of swallows in the autumn occurs by day. Swallows are not obliged to fly by night, like most of the smaller birds, for two very good reasons. In the first place they are strong and swift flyers, and can 


\section{SWALLOW ROOSTS AND MIGRATION}

accomplish more in half a day than many other birds in a whole one, and secondly they can feed while on the wing. Hence night work is not necessary for them, and the hours of daylight easily suffice for both feeding and travelling.

I have often seen in the fall great numbers of swallows flying leisurely towards the south over the beach and dunes at Ipswich during nearly the entire day. Now they skim close to the white sand, snapping up the surface flies and other delectable insects. Again they mount high in the air, and continue their southward journey, far removed from the earth. Again they alight to feed on bayberries, to rest and converse with each other. In the air they call to each other as they fly, just as do the nocturnal hosts, whose lack of skill on the wing and whose feeding habits, being of the earth or trees, require the extra night hours of labor. These night migrants, although heard, are invisible in the darkness, while the swallows delight the eye with their graceful flights in the full light of day.

A more spectacular migration of swallows I have sometimes observed. Here the resting hosts, moved by a common impulse, or in re- 


\section{SAND DUNES AND SALT MARSHES}

sponse to some mysterious signal, mount into the air in irregular circles, at times drifting together and whirling about like masses of smoke, all the time rising higher and higher. When so high that the individual birds can with difficulty be distinguished, they move off towards the south, and with their rapid flight are soon lost to sight. With the evidence of migration so apparent, it is a curious fact that for many years it was believed that swallows retired to the bottoms of ponds in the fall and spent the winter dormant in the mud! 


\section{CHAPTER VI}

WATER BIRDS SEEN FROM THE DUNES

"Thou little bird, thou dweller by the sea, Why takest thou its melancholy voice, And with that boding cry Along the breakers fly?"

- DANa.

W

HILE the seacoast is a favorable region for the observation of land birds, it is doubly so for that of water birds, which stream along the coast during both spring and fall in great numbers. It is much to the advantage of the bird student that the migration period of water birds occupies a very considerable part of the year, for the fall migration begins as early as the first week in July, and extends through December and even into January, while the spring migration extends from February to the middle of June. Not only this, but a large number-not of species, it is true, but of individuals-spend 


\section{SAND DUNES AND SALT MARSHES}

the summer, while in the winter the number both of individuals and of species is large, and there is always a chance of rare visitors from the north at this season.

While a rain or snow storm, or even a wind, makes the observation of land birds difficult or even impossible, the same conditions on the seashore are to a certain extent favorable to the bird student, because birds that habitually stay out at sea may be driven to the beach, or may wing their way in the storm close to the dunes.

There are two main classes of water birds that can be watched from the sand dunes and surrounding beaches, namely those that obtain their food on or in the water, and those that feed on the beaches. The herring gull belongs to both classes, and on this account, and also because it is found at all seasons of the year at Ipswich, and on occasions in enormous numbers, it deserves first place in our consideration.

Although No-Man's-Land in Penobscot Bay, over a hundred miles northeast, is the nearest breeding place of the herring gull, yet throughout the breeding season this bird is to be found in flocks of several hundred $\mathrm{ol}^{\circ}$ 


\section{WATER BIRDS}

even several thousand on and near Ipswich beach. Many of these, sometimes as many as ninety per cent., are in the gray and mottled immature plumage, and are probably nonbreeding birds. It is possible, however, that some adults, perhaps only a few, are daily excursionists from their breeding places in Maine to the beaches of Essex County.

The moving cause for the accumulation of gulls in summer in this region is the great abundance of dead fish so often found here, and the herring gull is a very useful scavenger. Young herring in their mad flight from larger fish meet their death by thousands on the sands, while hake, haddock and cod, as well as dog-fish-those fierce and ravenous sharks -are often stranded in the shallow water, and, battered by the waves, are cast up on the beach, - pursued and pursuer together. Skates-curious kite-shaped sharks-and the still more curious angler-fish or fishing-frog also furnish food for gulls. The angler-fish is so named because it is supposed to allure its prey within reach of its great jaws by means of a dangling tentacle that resembles a rod, line and bait. One of these fish that I found on the beach was three and a half feet 


\section{SAND DUNES AND SALT MARSHES}

long and had a mouth a foot wide-a singularly open countenance.

While the herring gull feeds principally on dead fish and other refuse on the water and on the beach, it also devours crabs and snails and sea urchins whenever it gets a chance, and, on very rare occasions, plunges like a tern for small living fish.

I treasure in my memory a stormy July day, when the wind was sweeping down cold and wet on to the shore, when a fog-bank lay to the east and great dark cumuli to the north of a gray sea studded with white-caps, when patches of fleecy scud drove overhead, revealing here and there spots of blue sky, and when the surf moaned on the bar. Herring gulls were everywhere, for the sea had cast up for them a bountiful feast. The sand flats were splashed with great patches of young herring, here shining like silver, there looking dark and colorless, while windrows of hake and pollack and schools of dog-fish dotted the shore. The sand was covered with the gulls' footprints, and marked with great white splashes, while feather's were blowing about as from an open feather-bed. As I stood on the edge of the beach, bracing myself against the wind, I 


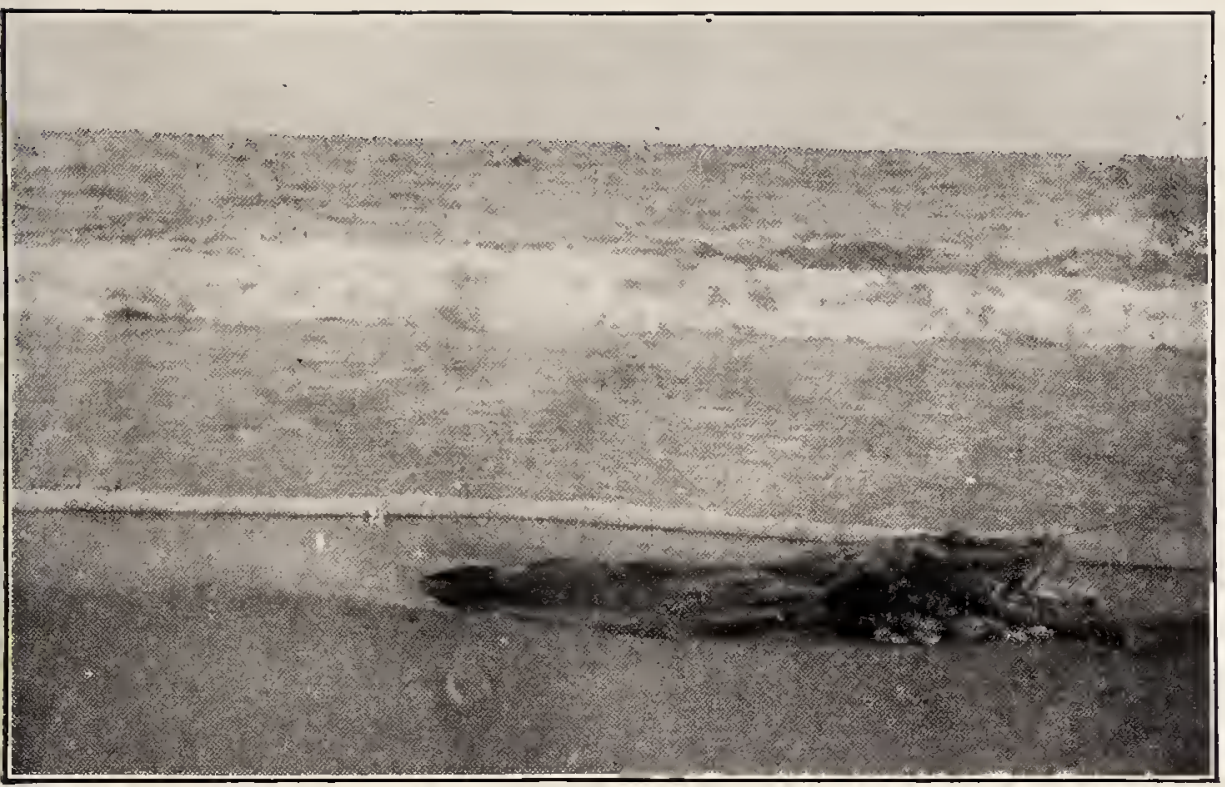

An Angler Fish Thrown Up on tile Beach.

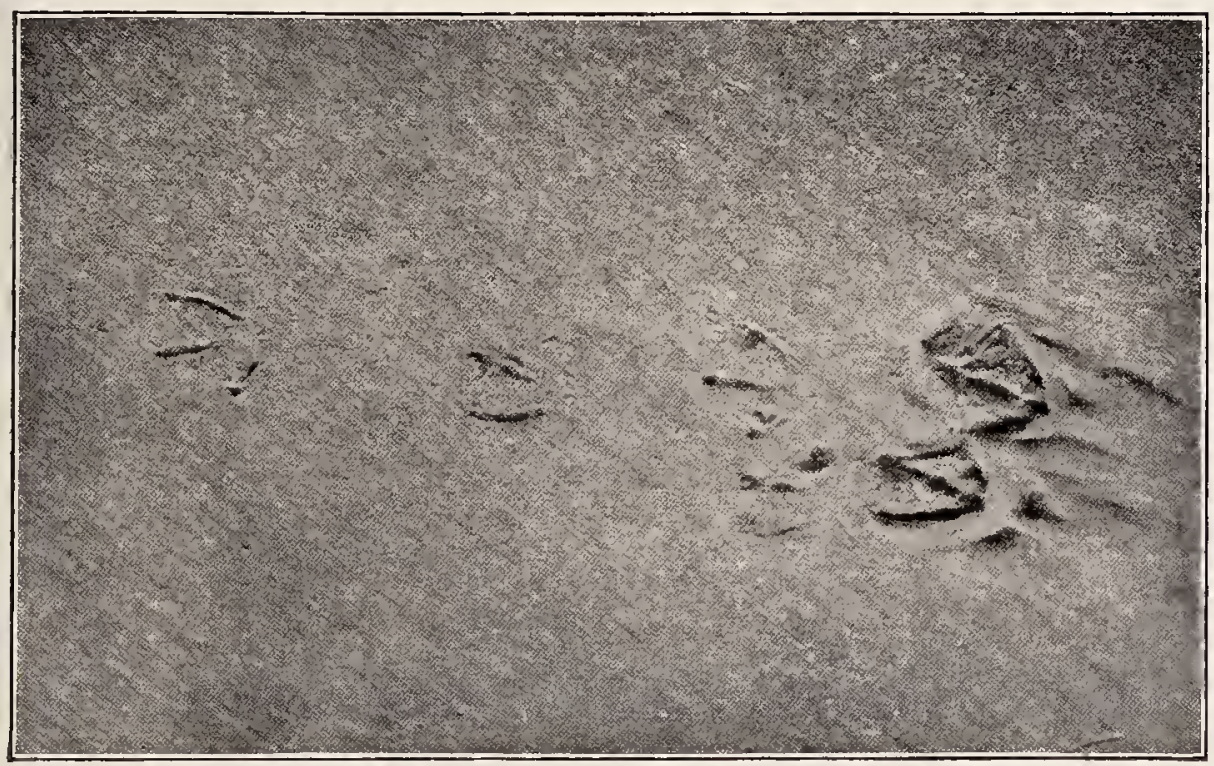

Tracks of Herrisg Gull made on Aligiting on tile Beach. 



\section{WATER BIRDS}

noticed that a bar on one side was so thickly covered with the great birds that no sand was to be seen, while on the other that the broad flat beach for at least a mile was thronged with them, a great army of gray and white. Overhead they were continually passing and repassing, drifting along before the wind or sailing straight into the teeth of it. Physicists have shown, it seems to me conclusively, that an up-current is needed in these cases, where gulls glide directly against a strong wind, as they often do for miles close to steamers, taking advantage of the up-currents there present. Over land or sea, under other conditions, it is rare that birds are able to glide far, for up-currents, although common for shorter spaces, are not so continuous as they are beside a moving steamer. Headley in his " Flight of Birds", says: "In Algeria I once saw two Eagles sail straight ahead against the wind for about a mile and a half without moving their wings till they reached a high mountain ridge, blowing over which the wind had got an upward trend."

It is a difficult matter to estimate the numbers of gulls in these large flocks, - it is impossible to count them,- and I have adopted 


\section{SAND DUNES AND SALT MARSHES}

several expedients in order to arrive at some idea of their magnitude. For example I have measured the size of a sand bar on which a flock had been so closely packed that the birds stood for the most part shoulder to shoulder. Again I have paced the distance occupied by a flock on the beach, or the distance along which the birds stretched when alighted in the water opposite the beach. Even allowing one bird to a square yard or eight or ten to each linear yard, the numbers sometimes went up as high as twenty-five thousand birds. I have never dared to record an estimate of over six thousand birds, for fear of exaggeration, but perhaps it is as unscientific to underestimate as to overestimate.

It would take long to write down all the interesting traits of this splendid gull. A few of them have incidentally been set down in the chapter on tracks. In these days, when young men dream dreams and see visions of themselves in aeroplanes, they cannot do better than to study the flight of this bird, and the marvelous manner in which it uses its aeroplanes. I believe that there is much to be learned by this study, much that will prove of immense interest and value to aviators, and 


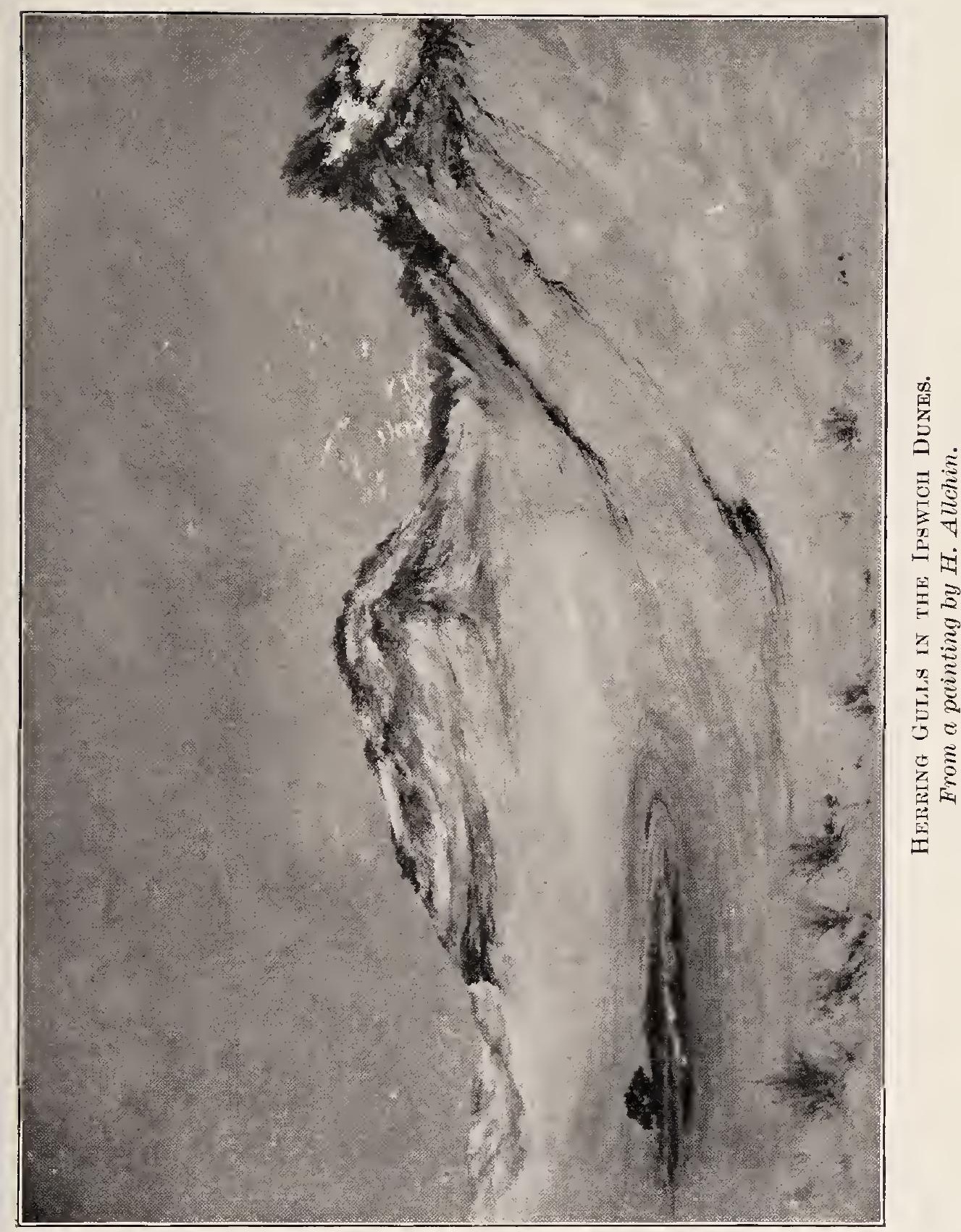





\section{WATER BIRDS}

they are even now discovering that by skilful management aeroplanes, like birds, can remain in the air for a considerable period of time and move in various directions without motive force.

While herring gulls in calm weather often flap along like herons, in stormy days they are totally different creatures, and appear to delight in the blasts, sometimes sailing, with wings slightly bent, straight into the wind.

"But when along the waves the shrill north-easter Shrieks through the laboring coaster's shrouds 'Be- * ware!' -

The pale bird, kindling like a Christmas feaster, When some wild chorus shakes the vinous air,

Flaps from the leaden wave in fierce rejoicing, Feels heaven's dumb lightning thrill his torpid nerves, Now on the blast his whistling plumage poising, Now wheeling, whirling in fantastic curves."

One can but admire the ease with which they circle and sail in calm weather or in storm, sometimes rising with imperceptible effort to a great height, their white plumage flashing in the sunlight.

"Now shaves with level wing the deep, then soars." 
In the descent they circle slowly down, or drop with great rapidity, tipping frequently from side to side to spill the wind in order to quicken the pace, and often slowly sinking the last twenty or thirty feet with outstretched legs and upraised wings. It will be a long time before human aeroplanes can compete with these past masters in the art.

One March day I noticed a gull rise from the water and fly with all speed directly at a golden-eye duck who was peacefully swimming not far off. The duck dove to avoid the blow that seemed imminent, and the gull took its place on the surface of the water. In a few seconds he was off to repeat the game on another duck, and so it went on. The victim always dove in time, the gull never picked up any food or appeared to be looking for anything the duck might have dropped, and the other ducks swam close to the marauding gull without any show of fear on their part or of malice on the part of the gull. I believe that the whole performance was in the nature of play between the different species living in a familiar and friendly manner in the same region.

I was once watching an immature herring 130 


\section{WATER BIRDS}

gull as it flew slowly close to the water at Ipswich, when a great fish, possibly a shark, threw itself completely out of the water at the bird. The gull flew up quickly, but soon circled down and dipped close to the water where the fish had disappeared, as if to satisfy its curiosity as to the cause of the strange disturbance.

The great black-backed gull is a fine fellow, larger than the herring gull, and is distinguished by black wings and back that contrast well with his snow-white head and tail. To this arrangement of plumage he also owes his name of "saddle-back." His bill is of a bright lemon hue, excepting the front part of the lower mandible, which is washed with brilliant carmine that shades out on the edges. When he opens his mouth his gape is seen to be orange and his tongue salmon in color. His eyes are pale straw colored stenciled with delicate gray lines, and his eyelids are edged with vermilion. A close acquaintance is needed before all these charms are revealed.

In the migrations and during the winter the saddle-backs are common birds on this shore, and, although their nearest breeding place is Nova Scotia, two or three generally spend the 


\section{SAND DUNES AND SALT MARSHES}

summer. Their cries are generally deeper than those of the herring gull and wonderfully varied and expressive. This is particularly the case during the breeding season on their home grounds. On the Labrador coast I have listened many times to these splendid birds, whose voices seemed almost human as they suggested anger, grief or derision. They often spoke in low conversational tones to each other as they sailed by, and at other times they scolded in no uncertain manner. I remember watching a pair of them eating a fish; their manners were extremely good; they ate in turns, never interfered greedily, and never quarreled. Saddle-backs are apt to be tyrannical, however, and chase and harry other gulls.

It is indeed a red-letter day for the ornithologist when he sees a glaucous or burgomaster gull, or an Iceland gull on this coast. These two species, denizens of the north, can be distinguished on close scrutiny from the herring gull by the absence of black tips to the white wings. The glaucous gull is slightly larger, the Iceland gull slightly smaller than the herring gull. Both have a mantle of slaty blue covering their backs when adult, but the 


\section{WATER BIRDS}

immature are of a uniform creamy white above and below.

Bonaparte's gull, one of the smallest gulls, is a common migrant, and kittiwakes and ringbilled gulls, although less common, are far from rare.

The common tern, often called mackerel gull, is easily identified by its swallow-like flight, its bill pointing downwards as it flies, and by its habit of hovering and plunging for fish, as well as by its loud cries of te-arr. Its bill is red with a black tip, its cap is black, its back of a lovely pearl gray, its lower parts white, and its tail long and forked. Not so many year's ago various fragments and the whole skins of these beautiful birds were fastened on women's hats, just as scalps and feathers are fastened in the head-dresses of savages. Thousands of the birds were shot down where they could be most easily obtained, namely, on their breeding grounds, for they are plucky little birds and valiantly attack any marauder who intrudes on their homes, and they do not seek to escape. These, as well as other species of terns, were greatly reduced in numbers by this cold-hearted combination of fashion and slaughterers, when, 


\section{SAND DUNES AND SALT MARSHES}

through the strenuous efforts of the Audubon Society and of other bird lovers, the killing was stayed, and, to the great joy of all naturalists, the graceful birds are again increasing. I have hopes that the least tern, which bred at Ipswich over forty years ago, and has been brought almost to extinction in the same way, may return again to its old haunts, now that fashion has been curbed by law.

The arctic tern closely resembles the common tern, but lacks the black tip to its bill, and has a somewhat different voice. It is far less common. Still rarer are the roseate and the great Caspian tern, but the little black tern is a fairly common migrant. All of these, I believe, are happily increasing in numbers since they have been afforded better protection.

It is a great pleasure to watch the graceful terns as they sport along the shore, now corering some sand bank as with a great white sheet composed of many hundreds of individuals. now rising and wheeling first one way and then another, all screaming loudly, now scattering and plunging for fish. Every now and then the bird watcher will notice a brown or mottled or jet black bird, lithe and graceful 


\section{W:ATER BIRDS}

as a hawk, dart in amongst the snowy terns, and scatter them to the right and left. Now he singles out one bird and chases it vigorously as it twists and turns in a vain effort to escape. Wearied at last, the tern drops a fish, which is at once seized by the intruder before it strikes the water. This is the way the jaegers, as these hunters are called, obtain their daily food, for they are robber barons, not laboring men. But "there are as good fish in the sea as ever were caught," and the terns do not suffer much, I suppose, from this tyranny. Occasionally, however, the victim appears to lose its temper and turns and chases the jaeger. The screaming is incessant and the two twist about in a bewildering way, as each tries to rise above the other, but I have never seen any harm result. There are three kinds of jaegers to be seen at Ipswich, the Pomarine, the parasitic and the long-tailed, and all have a light and a dark plumage, which are as different from each other in appearance as the red fox is from the black fox.

Perhaps the most spectacular performance by birds along this coast is the herring fishing in which the gannets indulge. Gannets are migrants only, birds of passage, and are often 


\section{SAND DUNES AND SALT MARSHES}

common in the fall when herrings swarm in Ipswich Bay. I have counted over two hundred gannets, all busily engaged in fishing, which with them is a lively and not a contemplative occupation. 'When a large flock are throwing themselves from considerable heights at the water, one bird after another in quick succession, or a number at once, sending the water up in great spouts, one is reminded of a naval battle, or at least of its counterfeit presentments. The fishing process in detail is as follows: the gannet flies rapidly over the water and begins to soar at a height of from thirty to a hundred feet, often rising just before the plunge. At the plunge the head is pointed down, while the wings are partly spread, so that the bird appears like a great winged arrow. The speed of the descent is great, and the wings are closed just before the bird enters the water, which spurts up to a height of five feet or more. After the waters have subsided, following the splash, and all is still, the bird suddenly and buoyantly comes to the surface, the head and neck stretched out first. It then sits quietly on the water for half a minute or so, to finish swallowing its prey and to rest, when it slowly and laboriously 


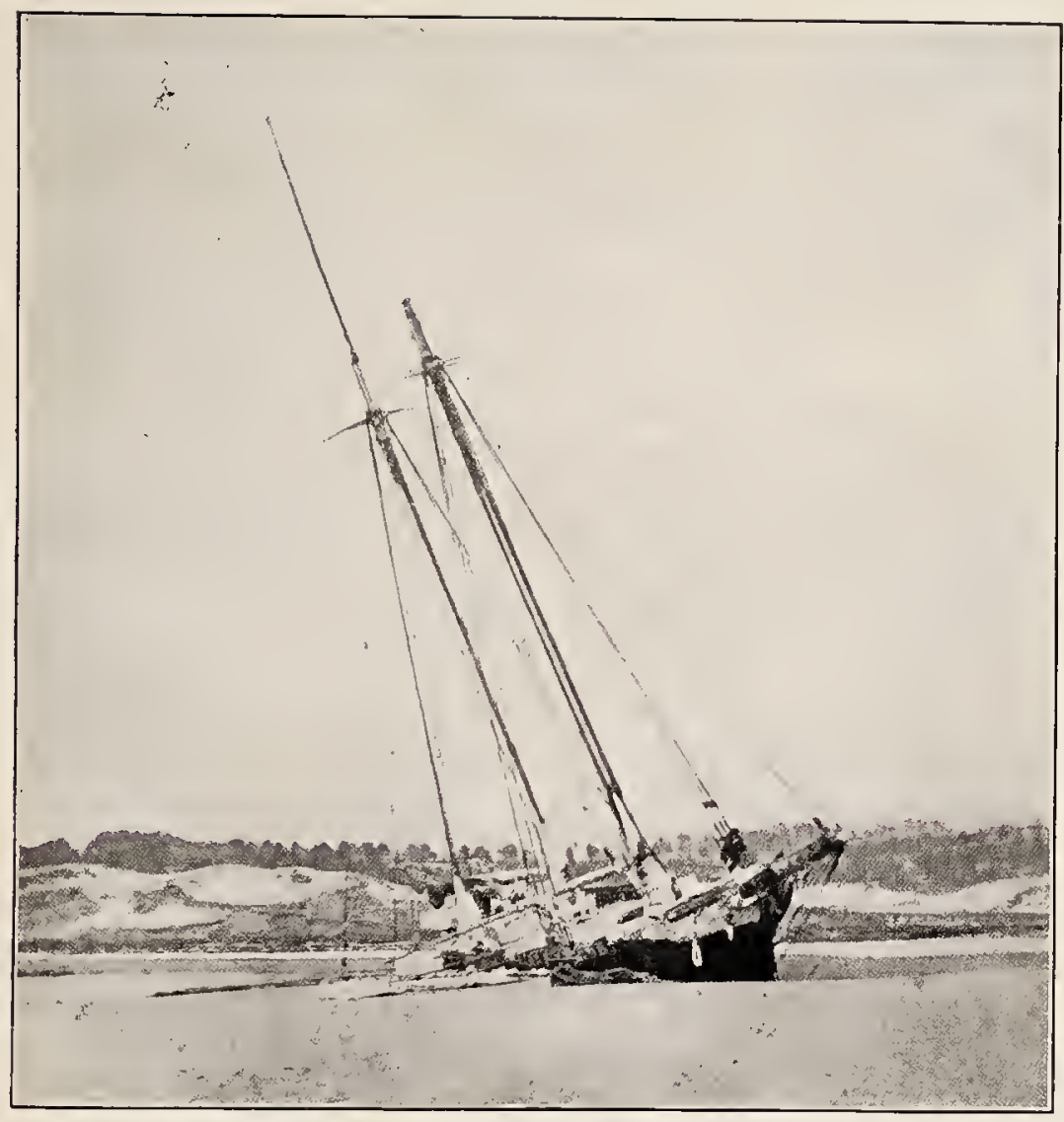

The Wreck of the SAND Schooner.

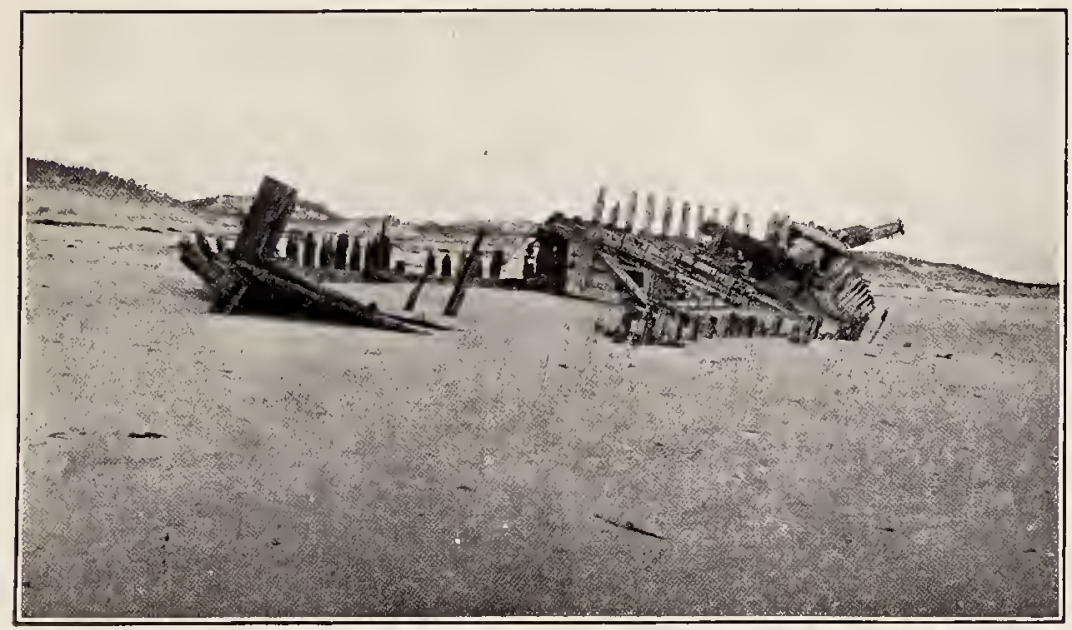

T'he Wreck a Year Later. 



\section{WATER BIRDS}

rises to windward, with its long neck and tail stretched to their full extent. Gaining a sufficient height, it swings round to leeward, and is soon soaring and plunging again.

The adult gannet is chalky white all over except for the outer halves of the wings, which look as if they had been dipped in ink. The shape of the bird is characteristic with its long neck and tail, but the spectacular plunging makes its recognition an easy one.

While the gannet is sometimes called a "Solon goose," its cousin, the shag or cormorant, is called in the South a "nigger goose" on account of its black color. The derivation of cormorant, namely from corvus marinus, also points to its dusky hue. There are two kinds of cormorants seen along this coast in the migrations, the commoner of which is the double crested cormorant, and the rarer bears, paradoxically, the name of common cormorant. The latter bird in small numbers sometimes passes the winter here. They are uncanny looking birds, veritable imps of darkness.

The double crested cormorant has two little tufts of feathers, one on either side of its head, and while its whole plumage is black with a 


\section{SAND DUNES AND SALT MARSHES}

purple metallic sheen, it is provided with several points of brilliant color. Thus its throat is bare of feathers and is of an orange color, as is also the bare skin at the base of the bill and in front of the eye. The eyelids are jet black with a beading of blue spots, while the eyes themselves are an emerald green, and the inside of the mouth is painted a vivid blue. Its neck is long and snake-like, while its great feet are like bats' wings with webs connecting all the toes. Perched on a spar buoy, a favorite spot, it sits upright, resting on its tail with its neck curiously curved. It frequently sits in spread-eagle style, with wings stretched widely, the head turned to one side and upward, looking for all the world like the eagle on an old mirror. This position is sometimes held for ten minutes at a time, and is occasionally indulged in by the birds even when they are sitting on the water.

That cormorants in flight are sometimes mistaken for geese is not surprising, yet their uniform black color, their broader and more slowly flapping wings, as well as the slight curve in their necks, makes their recognition easy. They fly in flocks of from ten to a hundred or more, and may stretch out in a long 


\section{WATER BIRDS}

line abreast or one behind the other, or the flock may even assume the typical $\mathrm{V}$ shape which is supposed to belong only to flocks of ducks and geese. On the water they look like loons, except for their blackness, and they are most expert in diving and catching fish. Occasionally they alight on the beach, where their attitudes and motions may be watched and their footprints examined. One pair in rising into the air made five hops before they could clear the beach, a distance of four yards. Another bird, with a stronger wind to help him, pushed the beach back only three times.

Wood in his "New England Prospect," written in 1634, says of these birds: "Cormorants bee as common as other fowles, which destroy abundance of small fish ... they used to roost upon the tops of trees, and rockes, being a very heavy, drowsie creature, so that the Indians will go in their Cannowes in the night, and take them from the Rocks, as easily as women take a Hen from roost." Old Josselyn, however, says: "I cannot commend them to our curious palats." I have ventured so far as to eat their eggs, but that was in Labrador.

In thick stormy weather Mother Carey,s 139 


\section{SAND DUNES AND SALT MARSHES}

chickens or petrels - either Wilson's or Leach's - sometimes fly close to the beach. They are black birds nearly the size of robins, with white patches on their rumps. Leach's petrel has a forked tail and short legs, while in Wilson's petrel the tail is not forked, and the legs are so long that when stretched out behind, as the bird is flying, they reach beyond the tail. While the Leach's petrel breeds along the Maine coast and farther north, Wilson's petrel breeds in the antarctic regions in the summer, our winter, and comes north across the equator to spend the northern summer with us.

Much might be said about various loons, auks, and grebes that can be seen from the dunes, but many of these prefer rocky shores. The loon-that splendid great diver that advances more rapidly below the water than on the surface-the smaller red-throated loon, and the horned and Hoelbell's grebes are, however, familiar birds along these sandy shores.

In the duck family the first on the list is the red-breasted merganser or sheldrake, he with the saw-like bill, the bec-scie of the Acadians. Of late years this bird appears to have 


\section{WATER BIRDS}

increased in numbers, owing, I believe, to the stopping of spring shooting, and also, I am inclined to think, to the action of M. Meunier, the chocolate king of France. This gentleman has acquired the great island of Anticosti in the Gulf of St. Lawrence, and has excluded all guns from his realms. Anticosti is a wonderful breeding ground for various water-fowl, and among them the sheldrake abounds.

On a late October day in 1910 the water outside of Ipswich beach for its entire length seemed to be filled with sheldrakes. Everywhere one looked were small and large flocks of these birds, either sitting on the water, swimming about and diving, or restlessly rising up and flying to and fro. It was a wonderful sight, and my companion, a most cautious and conscientious observer, estimated in his enthusiasm at least fifty thousand birds. There may have been many more. But it can safely be said that there were at least twentyfive thousand.

Although it is not uncommon to find two or three red-breasted mergansers spending the summer, none breed here, but in the autumn great hordes come from the north. After the first or middle of November they fall off 141 


\section{SAND DUNES AND SALT MARSHES}

greatly in numbers but are still abundant throughout the winter, while in the spring they again increase. In the early autumn all these mergansers appear to be in the modest dress of the female and young,- brown heads, ashy gray backs and white breasts. Towards the end of November it is evident that some of them, perhaps a quarter, are changing into the beautiful dress of the adult drake, while by the last of December and throughout January and February it is very rare to see a bird in female attire. In March the females put in an appearance, and courting begins, and by the last of April and in May the birds are largely paired, although flocks of either or both sexes are common. Both the drake and the duck have crests, but while that of the duck is dull brown, the crest of the drake is colored like the whole of his head and neck, a dark metallic green. The drake has also a white ring around his neck and a band of reddish brown streaked with black on his breast, while his flanks and wings show much more white than is to be seen in the duck. His bill is colored red.

The explanation of the seasonal distribution is interesting. It is evident that the great 


\section{WATER BIRDS}

multitudes in the fall-all in somber plumage - are made up of young of both sexes and of adult females; but it is not so clear, although it is a fact that the flocks also contain adult males which are in the so-called ectipse plumage. The males of nearly all species of ducks, soon after the period of courtship is over, change, by moulting, from their conspicuous nuptial dress to the quiet and dull-colored dress of the female. This is what is meant by going into the eclipse plumage, and the fact is in itself a strong argument in favor of the theory of sexual selection.

In the case of the eider, the drakes in nuptial plumage are wonderfully brilliant in their dress of creamy white, jet black, deep blue and pale green. It is evident that they appreciate their own beauty, for during courtship they display their charms by various antics, including the rising up from the water so as to show the splendid black belly shield otherwise hidden. In all situations, whether on the open sea or on land, among ice, rocks, spruces or mosses, they are extremely conspicuous, while the duck, in the modest but tasteful dress of brown, is always difficult to distinguish. Immediately after the courtship period the drake 


\section{SAND DUNES AND SALT MARSHES}

also assumes this dress, which becomes for him an eclipse plumage in very truth.

Now, in the case of the mergansers, the drakes emerge from their eclipse in late November, but their charms are wasted for a time, because the ducks with their young, as sometimes happens with the females of the human species, betake themselves to a warmer climate. The males are left to fight the battle alone in the north, until the more genial weather of the spring brings back the females and young from the south.

The southern side of this picture, which rounds out and corroborates my northern observations, has been given me by Mr. William Brewster, who says that in Florida in winter he has seen large flocks of female and immature red-breasted mergansers, and by Mr. Arthur T. Wayne, who, in his "Birds of South Carolina," says of this species: "From the time when the fish-eating ducks arrive until the first week in February the adult drakes are seldom, if ever, seen, but towards the second week in February they make their appearance in large numbers."

The old males brave the rigors of the northern climate, while the females and young seek 


\section{WATER BIRDS}

warmer regions during the winter, but it would seem as if some of the impatient suitors were unable to await the return of their partners from the south, and must needs go and fetch them.

The red-breasted merganser has a spectacular and distinctive courtship display, which varies somewhat in its details but is essentially as follows: the drake begins by stretching up his long neck so that the white ring is much broadened, and the metallic green head, with its long crest and its narrow red bill, makes a conspicuous object. After a preliminary bow, the bill is opened wide and the bird stiffy bobs or teeters as if on a pivot, in such a way that the breast and the lower part of the neck are immersed, while the tail and the back part of the body swing upward. This motion brings the neck and head from a vertical position to an angle of forty-five degrees. All the motions are stiffly executed, and suggest a formal but ungraceful courtesy. When the bill is opened, a loud, rough or purring and slightly double note is emitted, a note that remains long in the memory after one has heard it repeated over and over again by a number of merganser suitors. 


\section{SAND DUNES AND SALT MARSHES}

Although the female may remain passive and coyly indifferent to the ardent actions of the male, as is the habit of her sex, she sometimes responds by a bobbing which is similar to that of the male, but of considerably less range, and sometimes she emits a single note which is louder than that of her partner but of a different quality and less rasping. The nuptial performance is always at its best when several drakes are displaying their charms of movement, voice and plumage before a single duck, and each vies with the others in the ardor of the courtship.

I have records of some thirty other different kinds of ducks of this region, but it is possible to speak of only a few and that but briefly. Of these there are three species that go by the name of " coots," and their pursuit is termed " cooting," although the name coot belongs properly to that species of rail which is commonly called a mud hen. With such confusion of popular epithets it is no wonder that scientific names are preferred by those who wish to be exact. These " coots" that I speak of are really ducks, and they are known as the American scoter or butter-bill, the surf scoter or skunk-head, and the white-winged scoter. 146 

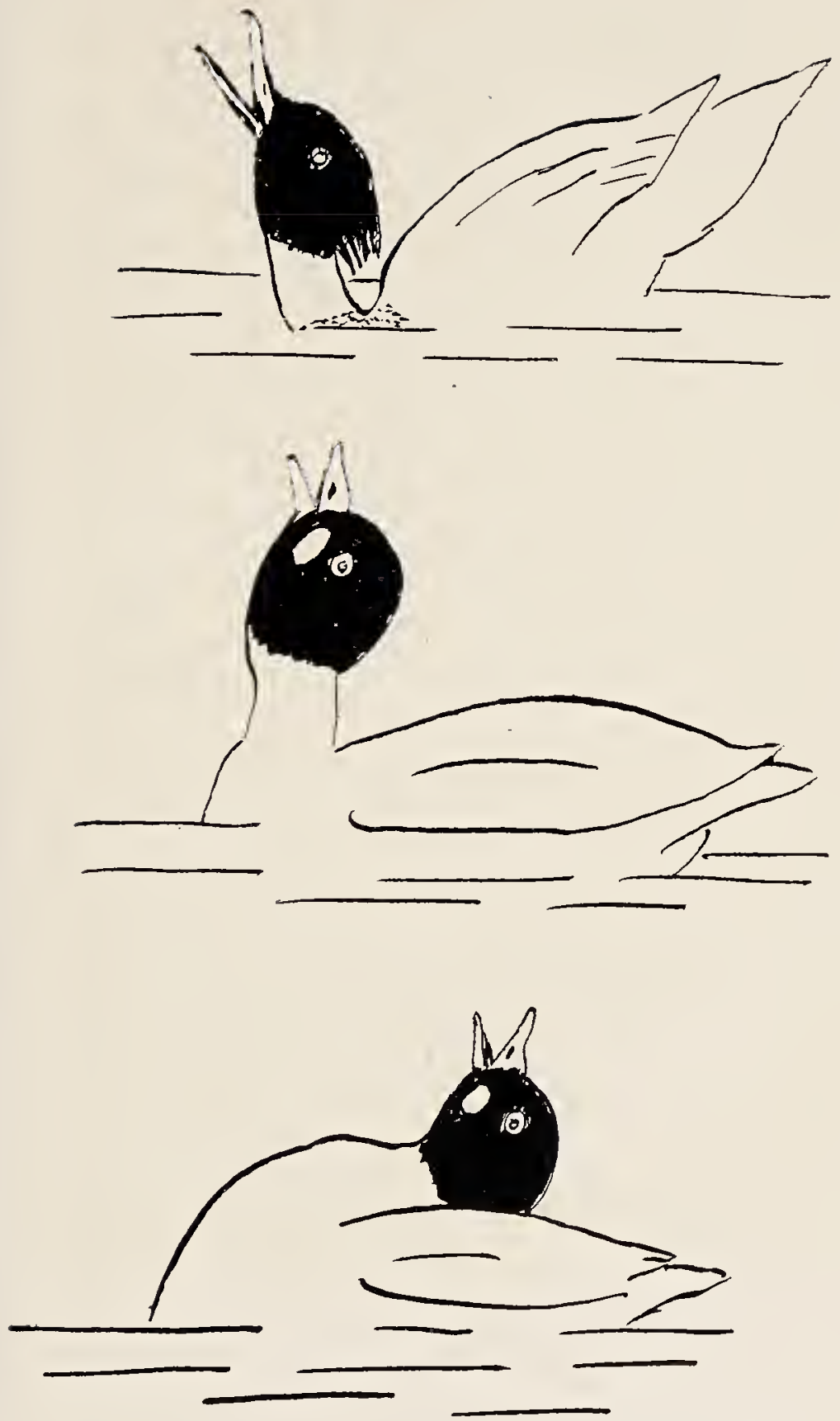

UpPer Figure - Courtship Pose of Shelldrake. Lower Figures - Courtship Poses of Whistier. 



\section{WATER BIRDS}

During October and November they pour along the coast, sometimes in great numbers, and at times flock succeeds flock as far as the eye can see off the beach at Ipswich. On days of great flights it is a fascinating study to watch these birds from the top of a tall dune near the beach as they sweep by with irresistible energy. On reaching the angle at Annisquam where Cape Ann juts boldly out, the birds often appear at a loss what to do. Sometimes they fly first one way and then another, rising higher and higher all the time, finally to strike out towards the end of the Cape, over which they resume their southerly course. Another flock will turn at the angle without pausing and skirt the shore around the Cape, but occasionally a flock will become discouraged on reaching the solid barrier and will turn back to drop in the water and talk it over. All this shows the dislike of the scoter to fly over the land, yet in stormy weather they fly directly over the base of the Cape.

Ducks are not famous as songsters, but there is a somewhat musical duck that appears in these waters, namely the old squaw, oldwife, or long-tailed duck. This handsome bird comes with the winter in a livery of snow 


\section{SAND DUNES AND SALT MARSHES}

white and jet black, and he bears a long and slender tail which he jauntily cocks up at an angle. In Labrador these ducks were spoken of as "hounds" by Cartwright over a hundred years ago, and they still bear this name there, and it is an appropriate one, for the voice of a flock is like the music of a pack of hounds in full cry. According to Preble the Cree Indians along the Athabasca call this bird ca-ca-wee, the Chipewayans of the Mackenzie River refer to it as a-ha-lik; while the Eskimos give it the name a-hau-lin. All of these names are very fair attempts to repeat some of the notes used by these birds. William Wood in his "New Englands Prospect" says "The Oldwives, be a foule that never leave tatling day or night."

Occasionally one may see in May a few old squaws that have changed to the summer dress in which they appear like negatives of their winter plumage. Instead of having a white neck and a dark spot about the eye, they have a black neck and a light spot. The color of the feathers near the eye remains in reality nearly the same-a mouse gray-but it appears dark with a white neck, and white with a black neck. 


\section{WATER BIRDS}

By far the most characteristic frequenters of the beach are the shore birds, a charming group in plumage, habits and call notes, a group that includes sandpipers and plovers. Up to half a dozen years ago the piping plover bred regularly in the dunes and laid its eggs in the sand. It belongs to a dying race, and although it is protected by law at all seasons, I fear this is not sufficient to stop its path to extinction. So long as the law permits the shooting of other plovers of the same size and the small sandpipers, one cannot expect the ordinary gunner to discriminate, as in fact he is unable to do, and the piping plover is shot with the rest. Only by stopping all shooting, or by the creation of bird refuges, can the tendency to extinction of this and other shore birds be prevented. Would that the Ipswich dunes, beaches and marshes could be made a bird refuge! It would be the greatest blessing to the birds and to bird-lovers alike, and incidentally to sportsmen elsewhere. At present a land owner prohibits the shooting of shore birds around the shores of a small pond at Ipswich Great Neck. The results are extraordinary and are well worth imitation, for the shore birds resort there in great numbers, both 


\section{SAND DUNES AND SALT MARSHES}

of individuals and of species. More than all this they become so tame and so much at home, that one can watch at close range traits and habits that are rarely seen on the open beaches, where the wary bird is constantly on the alert lest it lose its life.

The piping plover, meloda, has one of the sweetest and saddest notes I know,-a clear double whistle. It generally prefers to hunt its food in the dry sand, which it matches closely in color.

While the piping plover matches the dry sand, the ring-neck or semipalmated plover matches the wet sand where it generally hunts, and its notes are cheerful and business-like in comparison with those of its piping cousin. It is a robust bird, always on the alert for food and for the prowling gunner, and it still holds its own in considerable numbers. An advantage that plovers have over sandpipers is that they scatter when they alight on the sand to feed, while sandpipers hurry along in close ranks. Consequently the pot-hunter spends many anxious moments waiting for a chance to get a large number of plovers in a line with his aim, and often misses them altogether as the frightened birds take wing. As we have 


\section{WATER BIRDS}

already seen, the habits of these two groups of shore birds in this respect can be discovered by their tracks.

The golden plover is rarely found on this shore, and then only when it is blown out of its usual course, some two hundred miles or more to the eastward, for it has the extraordinary habit, after coming from its arctic breeding grounds, of migrating from Nova Scotia to South America, a distance of 2,400 miles over the ocean. From the northern coast of South America it journeys to Argentina, where it spends our winter, the South American summer. In the spring it migrates up the Mississippi valley, and finally reaches its home by the Arctic Ocean.

The black-bellied plover or beetle-head is, however, more a bird of our coast, for it migrates along our shore both spring and fall. It is a little bigger than the golden plover and is indeed a splendid bird with a body as large as that of a pigeon. It differs from the golden plover also in having a little knob of a hind toe, while the golden plover has no hind toe at all, and its under wing feathers or axillaries are black, while those of the golden plover are ashy. Its white rump is, how- 


\section{SAND DUNES AND SALT MARSHES}

ever, its most distinguishing mark when it flies.

I know of no more interesting shore bird to watch than the stately black-bellied plover, as it runs hither and thither on the sand, dabbing here and there with its short bill, or standing pensively, slowly folding its great wings after alighting. In the spring one may study all phases of plumage in a single flock, from those in winter dress with pure white breasts and bellies, through the slightly and profusely spotted ones, to those with splendid jet black breasts that contrast well with their white sides and necks. Thus on May 21, 1905, a flock of sixty-six of these birds ran by me as I lay concealed on the beach within a hundred yards, and I made the following census: nineteen were full black bellies; twentyseven were in various stages of incompleteness; twenty were pale bellies.

Their whistle is somewhat like that of the piping plover, but is deeper and longer and differs in accent. As a flock flies over, their voices come down as a shower of sweet yet mournful sounds.

The commonest sandpiper of the beach is the gentle little peep, a term that includes both 


\section{WATER BIRDS}

the mud-peep or least sandpiper, which is more often found in the marsh, and the sandpeep or semipalmated sandpiper, a typical sandy colored beach bird. In flocks large and small they eagerly glean the sand, running all together up the beach when threatened by a wave and following it as it recedes. Again they spring into the air and twist and turn like one bird with military precision, displaying now their gray backs, now like a flash their white breasts. The young, with the faint smoky wash on their breasts, come about the middle of August, a montl or so later than the earliest arrivals among their elders, and at first are very tame and confiding, not having yet learned the depravity of the human race or the range of their guns. They soon learn, or pay the penalty with their lives. One never tires of watching these birds, and desolate indeed would be the beach without them,-yet their extermination still goes on.

In the spring one is sometimes treated to their flight song, a musical quavering trill, which the bird pours out continuously as it rises on quivering wings. The song ends with a few sweet notes that suggest some of those of the goldfinch, and, after the excited bird 


\section{SAND DUNES AND SALT MARSHES}

has fallen to the ground, it emits a few low clucks. The whole performance is altogether delightful and unexpected.

The sanderling, locally known as " whitey" on account of its white appearance, is an abundant bird on the migrations both in spring and fall. It is somewhat larger than the peep, and its gray and white plumage makes it a conspicuous object as it flies in closely crowded ranks. In full breeding plumage it has a ruddy brownish throat and upper breast, but many go north in the spring still in the white of their winter plumage. The early arrivals in August or late July on the journey south are often ruddy-throated, but the change to winter plumage by moulting soon spots the throat with white until all the red feather's are gone.

In the middle of August the young, sadly inexperienced, arrive, and in their tameness fall an easy prey to the gunner. They are beautiful birds, with faint smoky bands across their white breasts. It is a great pleasure to watch a flock as they crowd together along the shore, probing every spot of sand for the small molluses and crustaceans which constitute their food. As the season advances our 154 


\section{WATER BIRDS}

pleasure is somewhat dimmed by the fact that cripples, with a foot shot away or bloodstained sides, are common in their ranks.

Josselyn in his "Account of two voyages to New England," published in 1675, says of sandpipers: "There are little Birds that frequent the Sea-shore in flocks called Sanderlins, they are about the biggness of a Sparrow, and in the fall of the leaf they be all fat; when I was first in the Countries the English cut them into small pieces to put into their puddings instead of suet, I have known twelve score and more kill'd at two shots."

There is always a chance of seeing less common or even rare shore birds on the beach, but it is out of the question to more than mention some of them here.

One beautiful Sunday morning in May, I heard the discharge of a gun, and immediately after a flock of knots-canutus, named after King Canute-flew by me on the beach. I looked to see who was breaking two laws by shooting on Sunday and in the spring, when I perceived that the offender had broken also a third law by shooting from a sailing dory off the beach. It was evident that his conscience was too guilty to allow him to look 


\section{SAND DUNES AND SALT MARSHES}

a man with binoculars in the face, for he put about and soon disappeared in the morning mists, leaving, however, three beautiful specimens dead on the beach. They were not wasted. The knot in the full nuptial dress is a handsome bird with breast like that of a robin and a steel gray back. In this stage it is called a red-breasted plover, while the fall birds in winter dress and the young with their white breasts and bluish gray backs are locally known as "blue plover." By these marks is the knot known, but especially by his short legs and squatty form.

The dunlin, with his curved bill, is a marked bird in the spring, on account of his bright chestnut back and black belly, while in the fall he retires into obscurity with a mousecolored back and white under-parts.

One would hardly connect the family of Napoleon with a sandpiper, but the nephew of Napoleon the First, Charles Lucien Bonaparte, was an ardent worker in American ornithology, and the white-rumped sandpiper is also known as Bonaparte's sandpiper. It is not much larger than a peep, but its white rump, noticeable in flight, furnishes a ready. means of identification. 


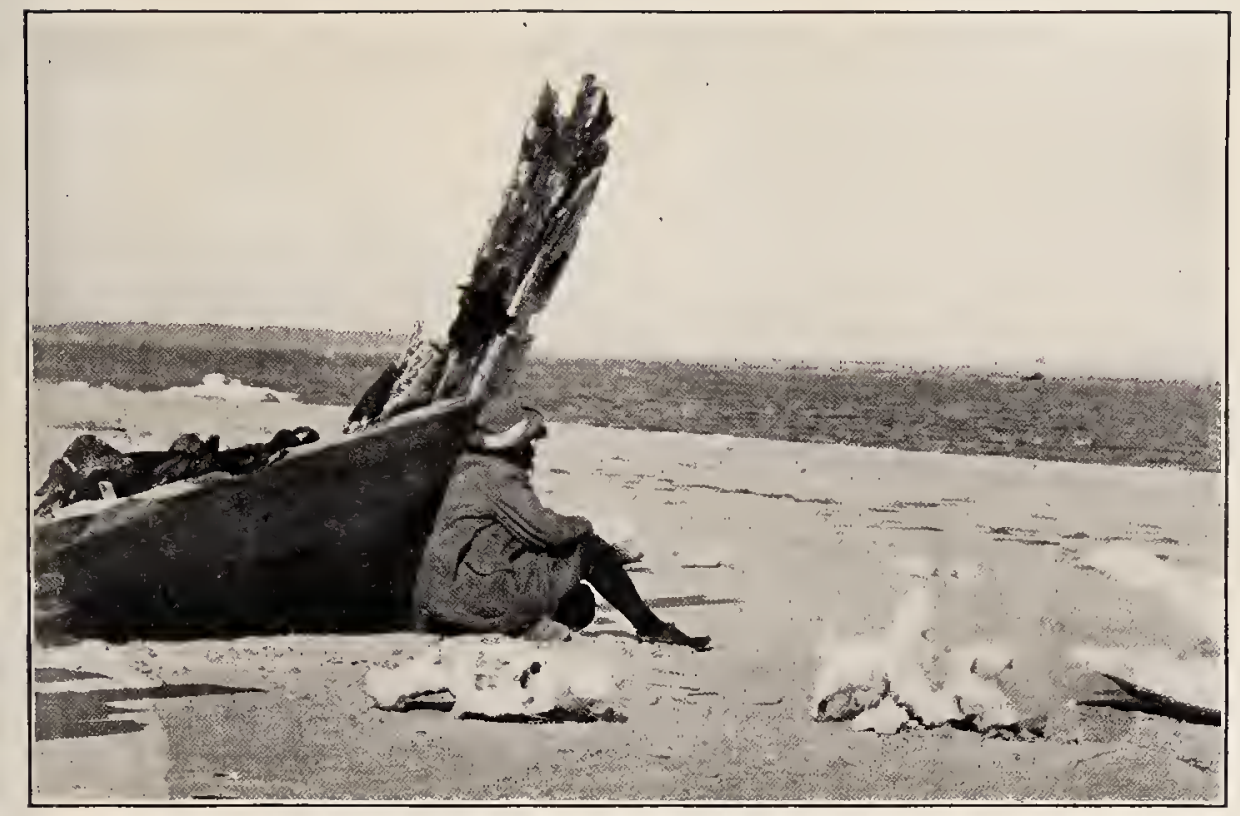

WATCHING WATER BIRDS AND SEAIS From THE Wreck.

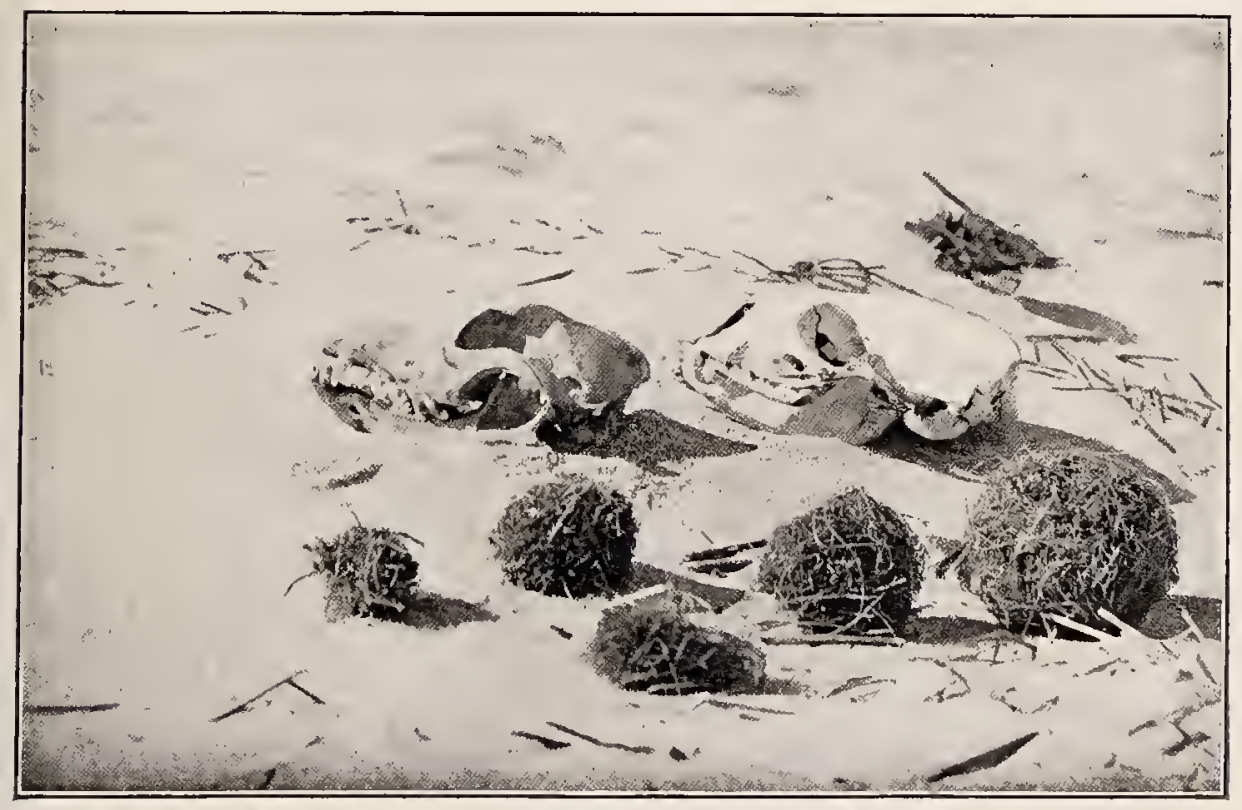

SkUl, of Dog (IEFT) AND of Shal (RIGHT). Grass Balls. 



\section{WATER BIRDS}

The Eskimo curlew - the dough bird of old New England gunners - is a bird of the past, for it is now close to extinction, although in former days it sometimes visited this coast in the fall in large flocks. The last record I have in this region is of two shot at Newburyport in August, 1908. Audubon in his " Birds of America" says: "Previous to my voyage to Labrador I had seen only a single bird of that species, which was kindly given me by my learned friend William Oaks Esq. of Ipswich, Massachusetts, who had procured it in his immediate neighborhood, where as I have since ascertained, the Esquimaux curlew spends a few days in early autumn while on its way southward."

The Hudsonian curlew, however, is a not uncommon migrant. It is an interesting fact that young males of this species have such short bills that they are mistaken for Eskimo curlews, while old females have such long bills that gunners report them as sickle-bills, the very rare large curlew of that name. I have a young male in my collection with a bill 2.25 inches long and an adult female whose bill measures 3.65 inches. It is evident that the males in this race are hen-pecked! 


\section{SAND DUNES AND SALT MARSHES}

The Hudsonian godwit with upturned bill, the willet, the Baird's and the stilt sandpipers, I must merely mention by name, but the turnstone or chicken plover compels more than passing notice. His coral red legs and his black and tan and white " calico" back make him a marked bird, and his great variety of call notes adds to his distinction. He derives his name "turnstone" from the singular but useful habit he possesses of turning over stones for the small crustaceans concealed there. But he does not stop at turning stones, for he is particularly adept at turning over masses of seaweed, sometimes almost as large as himself. In fact he literally " roots" in the seaweed like a pig, and like a pig he grows inordinately fat.

Although very shy when pursued with a gun, I have found the turnstone a delightful bird to study with a glass, for he appears to grasp the situation and to recognize the friendly attitude so well that I have been able to approach within a few feet of the " rooting" bird and watch every motion.

What a joy it would be to have a return of the old conditions, when terns and piping plover bred in the dunes, and when shore birds 


\section{WATER BIRDS}

large and small thronged the beaches, and when the sea teemed with water fowl. Many of the birds I have mentioned in this chapter are on the way to extinction, some have already disappeared forever; a few, happily as a result of protection, are increasing. In Japan it is said that when travelling artisans see an eagle, they take out their sketching tablets and record its beautiful shape and attitudes. The barbarians of this part of the world try to shoot it, a fate they have often meted out to every large or unusual bird they came across, even if it were of no value to them, and they left it to rot where it fell. Fortunately times are changing and the people are gradually awakening to the idea that money value in food or plumage, or even in work done for man, is not the only thing for which birds should be protected. We are also beginning to realize that the interest which finds pleasure in the sport of bird destruction is a very limited and a very selfish one, and that the claims of the sportsman are not paramount to those of the nature student or even of the lover of natural beauty. 


\section{CHAPTER VII}

\section{THE HARBOR SEAL}

"Vagabond and unconfined!

Roving with the roving rain

Its unboundaried domain!

Kith and kin of wander-kind

Children of the sea!"

- Hover.

TARLY one April day an old man, who had rowed a heavy dory across from Plum Island, struggled up Ipswich beach, carrying on his arm a clam-basket full of turnips for the lighthouse-keeper. His back was bent with the weight of many years and the digging of many clams, but his eyes twinkled when I asked him whether he had dug the turnips on the bar, and he admitted that although " Robin reef" was a good place for sea-clams and seals, it was a pretty poor place for vegetables. Why it was called Robin reef he could not say, for he had seen " nairy a robin" there, but that had been its name 160 


\section{THE HARBOR SEAL}

as long as he could remember, and his father had called it Robin before him. The explanation, however, is a simple one, for robin or robyn is the Dutch name for seal, and has frequently been applied to reefs. For example, DeKay speaks of a reef of rocks in New York harbor " called Robins' Reef from the numerous seals that are accustomed to resort there," and it may be remembered that the Pilgrims came to New England after a sojourn in Holland.

Although the harbor seal is a common and characteristic animal of these regions, a creature of great bulk, sometimes weighing over two hundred pounds, and attaining a length of five feet, it is an animal of whose presence the casual observer is generally quite unaware. It belongs to the cosmopolitan group of hairseals that inhabit our eastern sea-coast as far south as New Jersey, and increase in numbers, both of individuals and of species, as one goes north. Rarely a harp or a hooded seal straggles to the Massachusetts shores, while on the Labrador coast a full half-dozen different kinds are to be found. All these are clad in short, stiff, bristly coats, which lack the soft . under-fur, for it is only on the Pacific coast 161 


\section{SAND DUNES AND SALT MARSHES}

that the true fur-seals, from which are obtained the soft sealskin jackets, are to be found. These animals belong to a very different family, often called sea-bears. They possess external ears, which are absent in the hair'seal, and their hind feet, instead of being permanently directed backwards as in the hair-seal, can be turned forward for walking purposes when on land.

It is believed that these two groups of seals have attained similar stations in life by two independent paths. The fur-seals trace their ancestry to bear-like animals, while the hairseals are thought to have come from an otterlike animal. Both groups are of comparatively recent origin, and are found first in the Eocene period.

As the tide ebbs the seals repair to Ipswich bar while it is still awash, and try to maintain their position against the battering of the waves. Occasionally one is caught broadside and rolled over by the breakers, while unusually heavy seas may suddenly carry all the herd into deeper water, where nothing but their round dark heads are to be seen bobbing about the submerged reef. However, the tide flows out rapidly, and one by one they man162 


\section{THE HARBOR SEAL}

age by hook or by crook to get on to the bar -if they are not actually stranded there-and soon the whole herd is established on dry ground.

With back braced against the timbers of an old wreck on the beach, and with a good telescope resting on a forked stick stuck in the sand, one can spend very enjoyable hours in the close company of these interesting beasts. Twenty years ago I have counted as many as fifty seals together on Ipswich bar, but of late years from fifteen to twenty-four is the usual number, although on March 10 , 1912, I found forty-four of these animals on the bar.

Splendid fellows are these seals, and wonderful in the variety of their coloration. As far as I know, this is the only mammal that varies so much in the color of its coat. At a distance the seals look very dark when wet, but of a uniform gray or buff when dry, while near at hand, or studied with a good glass, they display a great variety and considerable beauty of pelage. Some are nearly white with a silvery sheen, others delicately shaded in grays and browns, still others mottled with large dark spots or patches, while others still 163 


\section{SAND DUNES AND SALT MARSHES}

are so wonderfully decorated with small round spots that they suggest at once a leopard. This variation in colors occurs among both the males and the females, the young and the old, and one may see a small seal of a uniform silvery gray, and a large one leopardspotted, and vice versa. I knew one old silvergray fellow with great mustachios, who presented a singularly festive appearance, for a wreath of dark spots was disposed around his wrinkled neck. Another, a very dark individual, possessed a grayish white face that gave him a weird and at the same time a comical expression. Many of these sea-leopards are of a beautiful yellowish-olive hue, spotted with black, while others look decidedly greenish with gray spots, and others still are most striking in a coat of nearly pure white, ornamented with large round spots.

I said that the seals managed by hook or by crook to get up on to the bar, and, if one did not know that they were such experts in the water, one would pity their distressingly crippled methods of locomotion on land. The young seals habitually use their fore-flippers, generally together, rarely alternately, to haul themselves along, aiding their progress at the 164 


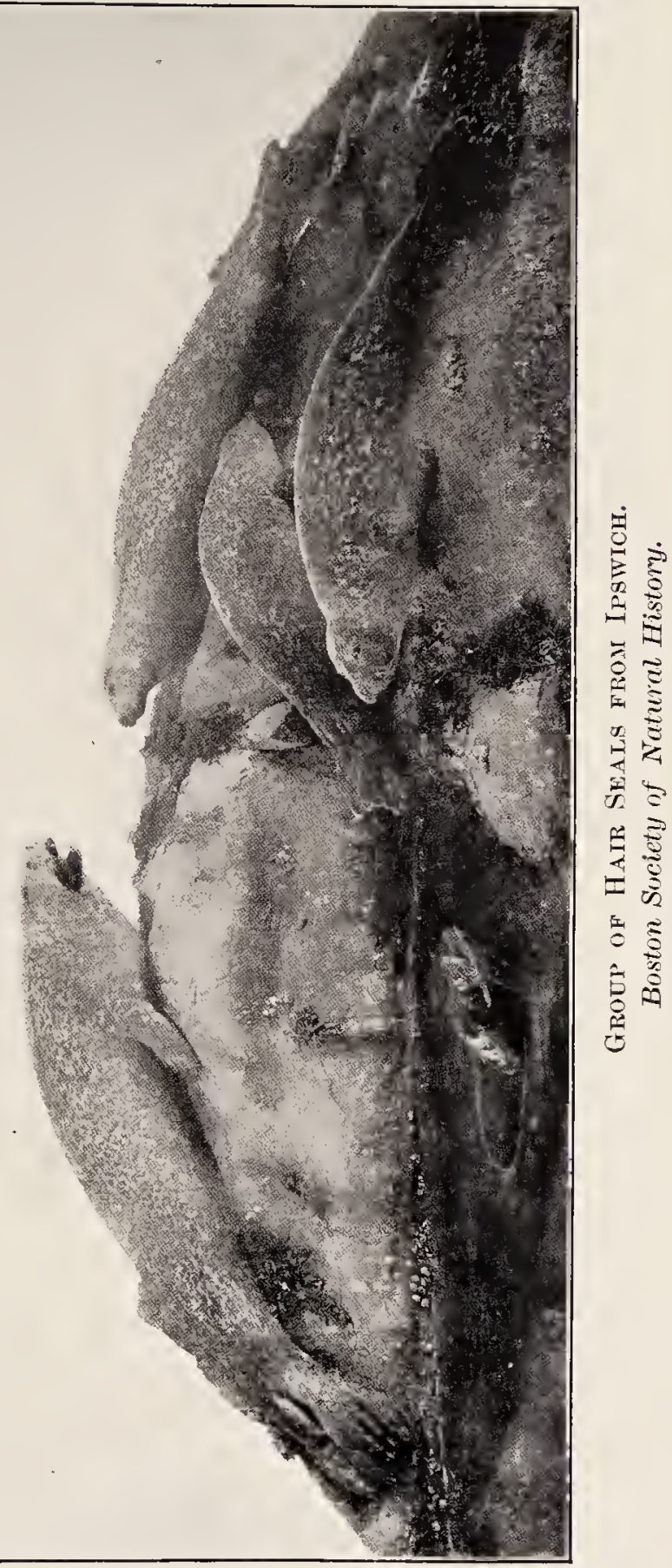





\section{THE HARBOR SEAL}

same time by a curious undulatory movement of the body, which, especially when seen head on, suggests strongly an otter or perhaps a caterpillar. The older individuals seem to prefer an entirely different and extremely singular method of progression, a specialized form of locomotion not even hinted at in any other mammal. They lie on one or the other side, with both flippers draped obliquely downwards over the chest and belly,-one cannot say where one begins and the other ends,-and they hitch along by a succession of wave-like shuffles and jerks, emphasizing the difficulties of their progress by frantic squirmings and wavings of the posterior end of their body. Now and then they fall over on their back in their strenuous efforts. I have seen a medium-sized individual hitch along partly on his side, using one flipper on the sand, while he waved the other helplessly or for balancing purposes in the air. There is no suggestion of their otter ancestry in these contortions.

This one-sided method suggests that the rotundity of the bodies of the seals-their portly aldermanic bellies-renders it impossible for them to reach the ground effectually 


\section{SAND DUNES AND SALT MARSHES}

with both flippers. This, however, seems not to be the case, for when a herd is disturbed by an approaching boat, all, young and old, shuffle down into the water on their bellies, using their fore feet as best they may. Fright makes them forget any special tricks of locomotion they may have developed, and causes them to return as far as possible to the ancestral quadrupedal method. In this case, however, it is a bipedal locomotion, for the fore feet lift up and drag the body, including the hind feet, which, although doing all the work in the water, are nearly helpless on land.

In repose the seals assume various positions. The least common is the one in which they are almost invariably depicted, namely flat on their bellies with a fore-flipper on each side. It is much more common for them to lie on one or the other side with flippers arranged diagonally across their chests, as just described, and occasionally they lie flat on their backs. Not infrequently a seal reclines in what might be called a Madame Récamier position,- on the side with head and neck stretching diagonally upwards. Some touch the sand for their whole length whether they are lying on their bellies, their sides, or their 166 


\section{THE HARBOR SEAL}

backs, and appear to be completely relaxed in sleep, while others are very wide awake, and assume a bent-bow position, the curve of the side or belly alone resting on the sand.

There are always some of the herd on the watch, and these often appear nervously overanxious, looking first one way, and then the other. Such large and intelligent eyes they have! There is something very human about these beasts. They certainly enjoy the luxury of their between-tide naps, even if there are anxious moments now and then, and it is very soothing to see a fat old seal, stretched flat on his back, extend both his apologies for arms on the sand, and indulge in a wonderful yawn which displays a huge pink mouth.

The posterior flippers-the hind feet-are generally carried palm to palm, or sole to sole, so that the thin edge points up and down in relation to the longitudinal axis of the body, instead of lying flat on the ground, as usually depicted. The seals frequently wave these flippers separately, spreading out the five toes, or press them together as if they were grasping hands; again they painfully bend one or both forward in a restrained manner that suggests hand-cuffs and a vain attempt 


\section{SAND DUNES AND SALT MARSHES}

to burst their bonds, - a pitiable state of affairs, if one did not know that this peculiar manacled arrangement of the hind legs forms almost a screw-propeller, which has given the seals such mastery in the water that they excel in speed even the fish, the real denizens of the sea. It is difficult to be both a specialist and an all-round animal at the same time. Man alone has solved this problem by the use of tools.

The short stumpy tail of the seal is very little in evidence, but as the animal painfully hauls out on the sand I have sometimes seen it erected, perhaps as the result of the hauling efforts, just as the tail of the Eskimo dog is believed to have attained its present lofty position, as contrasted with the horizontal tail of the wolf, from the straining at the sledges.

One would think that seals with their short, hairy coats and watery environment would be spared the petty annoyances that afflict most birds and beasts, yet such appears not to be the case, judging from the way in which they scratch themselves. The reach of the foreflipper is but short, yet with these they frequently scratch their heads and necks in a very significant manner. 

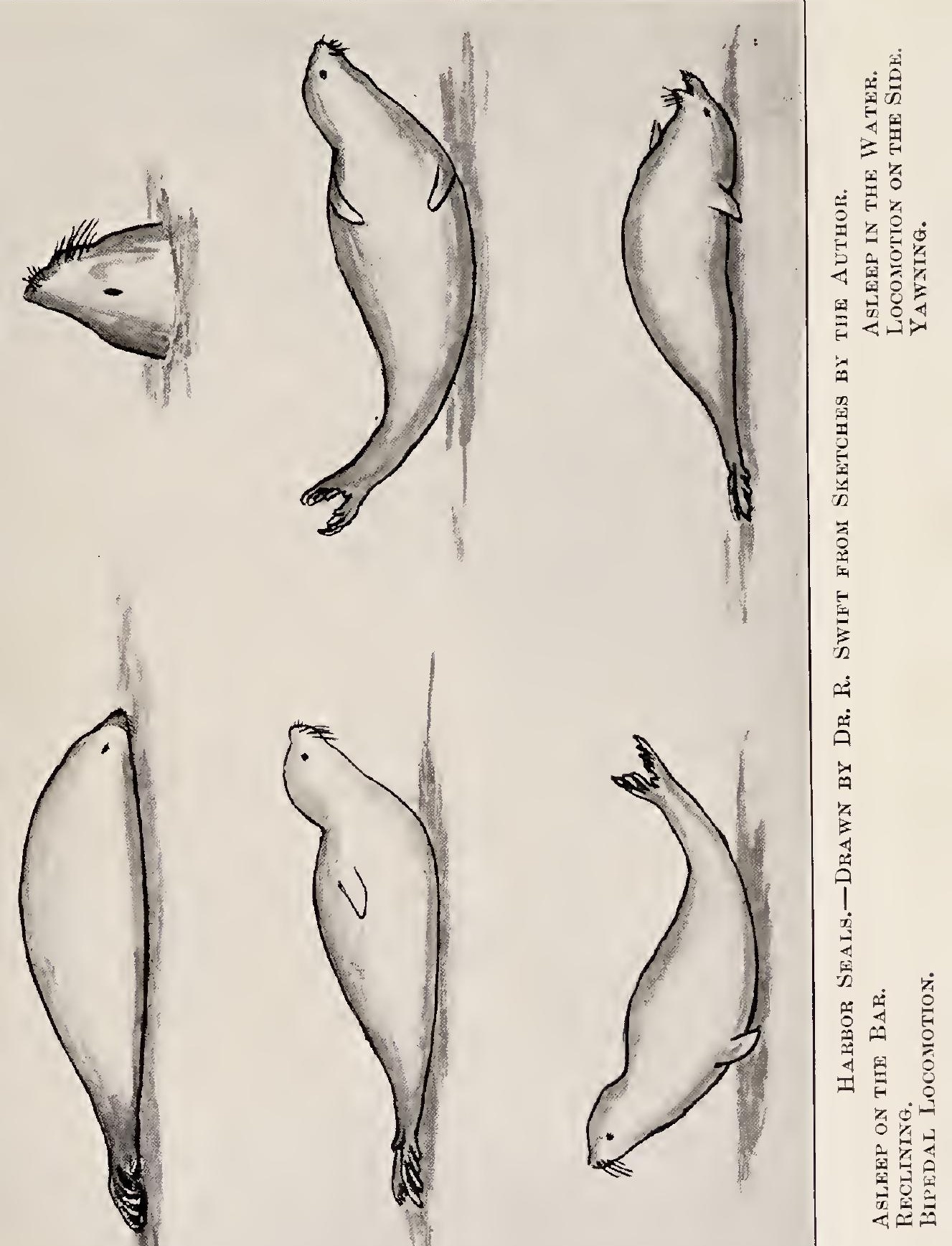



\section{THE HARBOR SEAL}

Every now and then the seals on the bar, with a nervous, undulatory effort, shift their position, and, if a boat approaches, they all depart in a panic into the water, with the clumsy, violent motion suggestive of a sackrace. Timid creatures they are, for they are well aware, through sad experience, of the bounty of three dollars that Massachusetts placed on their heads, - or rather tails. This bounty law was repealed in 1908, for the treasury had been nearly depleted by some Penobscot Indians, who, by the skilful manipulation of one or two seal-skins from Maine, were able to present numerous tails to the selectmen of various coast towns of Massachusetts. In all, these Indians collected several thousand dollars before they were detected. The object of the bounty was to diminish or exterminate the seals for the good of the fishermen, who, it was supposed, suffered from their depredations among the fish. That seals are great eaters of food-fish there can be no question, but they doubtless eat also many useless and perhaps harmful species. Occasionally a seal may be seen with a fish in his mouth, but as a rule the seals appear to swallow their prey under water. I have seen one come up 169 


\section{SAND DUNES AND SALT MARSHES}

with a silvery herring between his teeth, at once dive, to reappear without any external sign of his prey. In Labrador I have seen them dash through the water at the mouth of a river after the trout I was seeking to beguile, without once seeing any fish in their jaws. Their fishing effectually put an end to mine, but I was well repaid by the interesting scene. To many of us the aesthetic value of seal life along our coast well makes up for the loss in fish, a sentiment which the commercial fisherman I am afraid would not appreciate.

It always seems to be the custom among the seals, whether from disinclination to move, or from a love of sport,--and I suspect the latter is the true explanation,--to remain as long as they possibly can on the sand-bars while the tide rises. With extended heads and tails, they receive the buffeting of the waves and resist being swept away into the water, as if, indeed, they were fearful of being drowned or of even wetting their heads. Some of the seals, in their endeavors to hold their places against the waves of the rising tide, give up the attempt to keep their heads above water, but elevate their flipper-tail com- 


\section{THE HARBOR SEAL}

plex and hold on for dear life with their heads and fore-flippers. It is fine sport, but the tide always wins in the end, and the "back-tothe-land movement" on the part of the seal is soon forgotten in his modern life on the ocean wave.

In an easterly storm on an August day, when the rain and the mist and the spray were driving over the bar, a herd of twenty-nine seals was gathered at the highest point, for it is not merely to sun themselves that they haul out thus. A long, low-lying, grayishyellow sand-bar, a steel-colored sullen sea, a dirty gray sky and a seething mass of angry white breakers fringing the reef and extending in long lines on either side, formed fitting surroundings for these strange beasts. On a near-by point of the bar was a flock of perhaps a thousand herring gulls, among whom one or two great black-backed gulls could easily be distinguished by their large size, their snowy white heads and tails, and their jet-black backs and wings, while in a compact group apart were two or three hundred common terns. The deep voices of the gulls and the shrill cries of the terns sounded above the storm as the birds rose from time to time and 


\section{SAND DUNES AND SALT MARSHES}

circled over the water, while the booming of the waves formed a constant undertone.

To old Ipswich folk the voice of the ocean on the bar has interesting associations.

"I love to think of old Ipswich town;

Harry Main - you have heard the tale - lived there;

He blasphemed God, so they put him down

With an iron shovel, at Ipswich Bar;

They chained him there for a thousand years,

As the sea rolls up to shovel it back;

So when the sea cries, the goodwives say

'Harry Main growls at his work today:'"

There seems to be no uncertainty as to the crime but some diversity of opinion as to the punishment, for:

" On the bar of Ipswich, Harry Main, Restless of heart and hand, Through midnight tempest, rift or rain, Is coiling a rope of sand.

"Doomed for his sins to this vain toil, Blasphemous pirate he, -

For a thousand years to stand and coil This cable by the sea."

As the tide rose, the seals were crowded together on one of the highest points of the 


\section{THE HARBOR SEAL}

bar, the gulls on another, while the restless terns all took flight. Soon the waves began breaking among the seals, and a few of the outlying ones were floated away and their black heads studded the water, while the air was filled with departing gulls. A little later nothing but a mass of swaying flipper-tails and bobbing heads could be seen, and as the waves receded only eleven seals were left securely on the sand, while in the gull group one old solemn black-backed and fifteen or twenty herring gulls survived the onslaught. Again the waves rolled in from all sides, and continued their battering without pause; only one seal and one great black-backed gull remained; soon they too were gone and nothing but angry breakers were to be seen rushing in all directions, as if anxious to find out and pursue any creature that dared to oppose them.

It is easy to appreciate the motives of seals that are reclining in delightful ease on a bar under the rays of the summer's sun, but it is rather surprising to find them assuming similar positions in a heavy rain-storm, and still more perplexing when one discovers these same animals on the bar on a December 


\section{SAND DUNES AND SALT MARSHES}

day when the thermometer is but ten degrees above zero and the air is filled with snow as dry as dust scudding before a northeasterly gale. On such a day twenty-six seals were stretched in various positions of watchfulness and repose on the bar, and the snow was drifting about them. The use of the telescope was difficult, and I could not feel sure whether the water was frozen on their coats or not. The beasts were more apart than usual and apparently did not need to huddle together for warmth. A seal's circulation must be wonderfully active, and his coat of fur and blubber wonderfully warm. It is evident that the bar is sought for repose and not solely, as is generally supposed, for a sun-bath.

On June 11th, 1910, in a violent easterly rain-storm, conditions which ensure a delightful privacy on the beach, I witnessed an interesting scene near the mouth of the Essex River. On the inner side of a sand-spit, connected by a narrow isthmus with the beach, a large seal was lying close to a baby seal of about one-third of its length. The old one wriggled into the water as soon as it saw me, but presently returned, evidently to urge its young to flee with it. The young one appar- 


\section{THE HARBOR SEAL}

ently had not reached the age at which man is regarded as a thing abhorrent, and simply nosed about the mother. Again in her trepidation she took to the water, where she splashed violently with her hind-flippers. Several times she clambered up beside her young one and again in terror fled to the water, but at last, by dint of coaxing and pushing, the youngster was got into the sea. Thereupon the old one headed for the open ocean,-from which, however, it was separated by a line of breakers,-followed eagerly by the young one, who held its head and neck high above the water and splashed awkwardly with its fore-flippers in its anxiety to follow. At times the head of the young one was so close behind that of its mother, and a little on one side, that it seemed as if the baby seal were partly supported on its mother's back. Every now and then the mother would gracefully turn her head up and around, so that the mouth appeared to touch the outstretched mouth of the little one. What the object of this movement was, whether to encourage or to kiss the infant, or to give it nourishment, I was unable to determine, but the simultaneous action on the part of the 


\section{SAND DUNES AND SALT MARSHES}

mother and young, as performed several times, I could clearly see through my glasses.

Two or three times the mother dove, but remained under water only a fraction of a minute each time, long enough, however, to cause considerable anxiety on the part of her baby, who made more strenuous efforts at this time, and stretched its neck above water, as if looking for its mother, paddling vigorously meanwhile. They finally disappeared from my sight to seaward in the driving spray and spits of rain.

"Where billow meets billow, there soft be thy pillow; Ah, weary wee flipperling, curl at thy ease.

The storm shall not wake thee, nor shark overtake thee, Asleep in the arms of the slow-swinging seas."

The whole performance was an exceedingly interesting one from an evolutionary point of view, as well as a charming display of motherly affection and infantile helplessness.

Under ordinary circumstances the harbor seal displays great skill as a diver, and is able to stay under water the incredible length of ten or even fifteen minutes. When alarmed 


\section{THE HARBOR SEAL}

by the presence of man it almost invariably seeks safety in flight below the water. This not only ensures its safety from observation and chance of being shot, but gives it opportunity for greater speed, by the elimination of surface friction and wake, and by its assumption of a shape particularly adapted for cleaving the water. Now this adult seal dove but little, and that for brief intervals, as if she recognized the inability of her offspring to follow her. The baby seal did not dive at all; it evidently had not reached the diving stage in its development, and it was indeed but an indifferent swimmer, and splashed in a very amateurish manner. All this points to the very evident fact that the seals' ancestry goes back to land animals, and, just as the child of civilization bears the ear-marks of the savage, so the baby seal is more at home on the land than in the water. The baby seal has, however, the advantage of the baby man, for its progress to the arts of the adult is rapid, and this progress is not dependent on the careful instruction of its parents. That the mother does to a certain extent guide its ways, and instruct it in the art of swimming and diving and catching fish is probable, but 


\section{SAND DUNES AND SALT MARSHES}

that these various arts are inborn instincts, and would appear in due course of development in the entire absence of maternal supervision is also probable.

Many carnivorous animals, to which class the seals belong, are expert fish-catchers, as, for example, mink and especially otters. I have seen Eskimo dogs that were kept on rocky islands on the eastern Labrador coast plunge through the icy waters for fish, and spend much of their time in this pursuit. It is interesting to picture the gradual change of habit from a land carnivore to a sea carnivore, with a corresponding change of structure brought about by natural selection. The Acadians of southern Labrador call the seal le loup marin, and they are evidently more nearly correct than the modern Frenchman, who speaks of the seal as le veau marin.

My baby seal-the one whose actions I have just described-had already shed its white or milk coat and was clad in dark pelage. In the London Zoölogical Gardens, according to Flower and Lydekker, a young of this species " shed its infantile woolly coat and was swimming and diving about in its pond within three hours after its birth." 


\section{THE HARBOR SEAL}

It is generally put down in the books, and copied from one to another, that the young of seals are born in rocky caves just out of reach of the tide. Rocky caves are not abundant on the Massachusetts coast, certainly not in the neighborhood of Ipswich, and I am inclined to think that the young must often be born on sand-bars, or sandy or rocky islands, for it is very unusual to find a seal hauled up on the mainland on the closely populated Massachusetts coast. If they are born on sand-bars they must take to the water, or the water will take to them within three or four hours after their birth, and if, as is said, they never enter the water in their milk pelage, it follows that this must be shed very soon after, or in some cases even before birth. It is therefore possible, and indeed probable, that I arrived on the scene soon after the birth of the baby seal whose actions I have just chronicled, and that I witnessed its first unwilling bath. Like the silkie or seal in the ballad of "The Great Silkie of Sule Skerrie," the old one was trying to "teach him for to swim the faem."

While the baby seals are born in May and June, courtship takes place in the latter part 


\section{SAND DUNES AND SALT MARSHES}

of summer, particularly in September and October. How much of the actions of the seals is play and how much courtship it is difficult to say. It is not uncommon to find seals chasing one another and throwing themselves completely out of water in the exuberancy of their sport or courtship, falling back with a splash into their favorite element. Sometimes they project themselves diagonally upwards from the water, which they clear with all but the tail, and again they bound with great leaps over the surface, throwing themselves their full length with each leap. I have seen one swim before a breaker over a submerged bar, leaping forward five times as the wave repeatedly broke. Occasionally the play seems to go on just below the surface, which is broken from time to time by a perplexing display of flippers.

Oftentimes in September and October two seals will suddenly rise up from the water as far as their shoulders face to face, and occasionally they appear to bump noses or kiss. Then in a trice they disappear amid a turmoil of waters, and as they go down they usually throw up their tails and 


\section{THE HARBOR SEAL}

hind-flippers in the exuberancy of their spirits.

On the bars two seals often peck at each other in a sportive manner like two chickens, and rarely there is a momentary disturbance, as if an old one were swearing at one of the younger set for treading on his toes, but as a rule the time spent on the bars seems to be devoted to meditation and siestas.

On a raw March day I once witnessed an interesting seal exhibition, where a love of sport only was manifested. On this day with the ebb tide there was a procession of cakes of winter-ice floating down to the sea inside the bar of the Ipswich river. Some of the cakes bore masses of sand and mud or of thatch grass frozen into them and torn from the marshes. The game on the part of a couple of seals seemed to be to get on to the larger cakes and have a boat-ride, tossing about in the waves. The clambering up proved often difficult, and if a seal failed at one cake he would try to board another. One seal floated contentedly down into the bay, and he could be distinguished for a long distance, for his dark coat contrasted well with the white ice. Seals have advanced far on 


\section{SAND DUNES AND SALT MARSHES}

the educational road, as shown by their ability to sport and play.

As a seal thrusts its high-browed head above the surface, and regards curiously the occupants of a boat, it has a strangely human look, and this similitude is increased to an uncanny extent if a seal happens to be one's companion while swimming. There is a very intelligent and questioning look in the direct gaze of their lustrous eyes, and it is not to be wondered at that seals were mistaken by the early mariners for mermaids.

Henry Hudson, in the journal of his voyage of discovery in search of the northwest passage in 1608, relates: "This morning, one of our companie looking over boord saw a mermaid, and calling up some of the companie to see her, one more came up, and by that time shee was come close to the ship's side, looking earnestly on the men: a little after, a sea came and overturned her: from the navill upward, her backe and breasts were like a woman's, as they say that saw her; her body as big as one of us; her skin very white; and long haire hanging downe behinde, of colour blacke: in her going downe they saw her tayle, which was like the tayle of a porposse, 


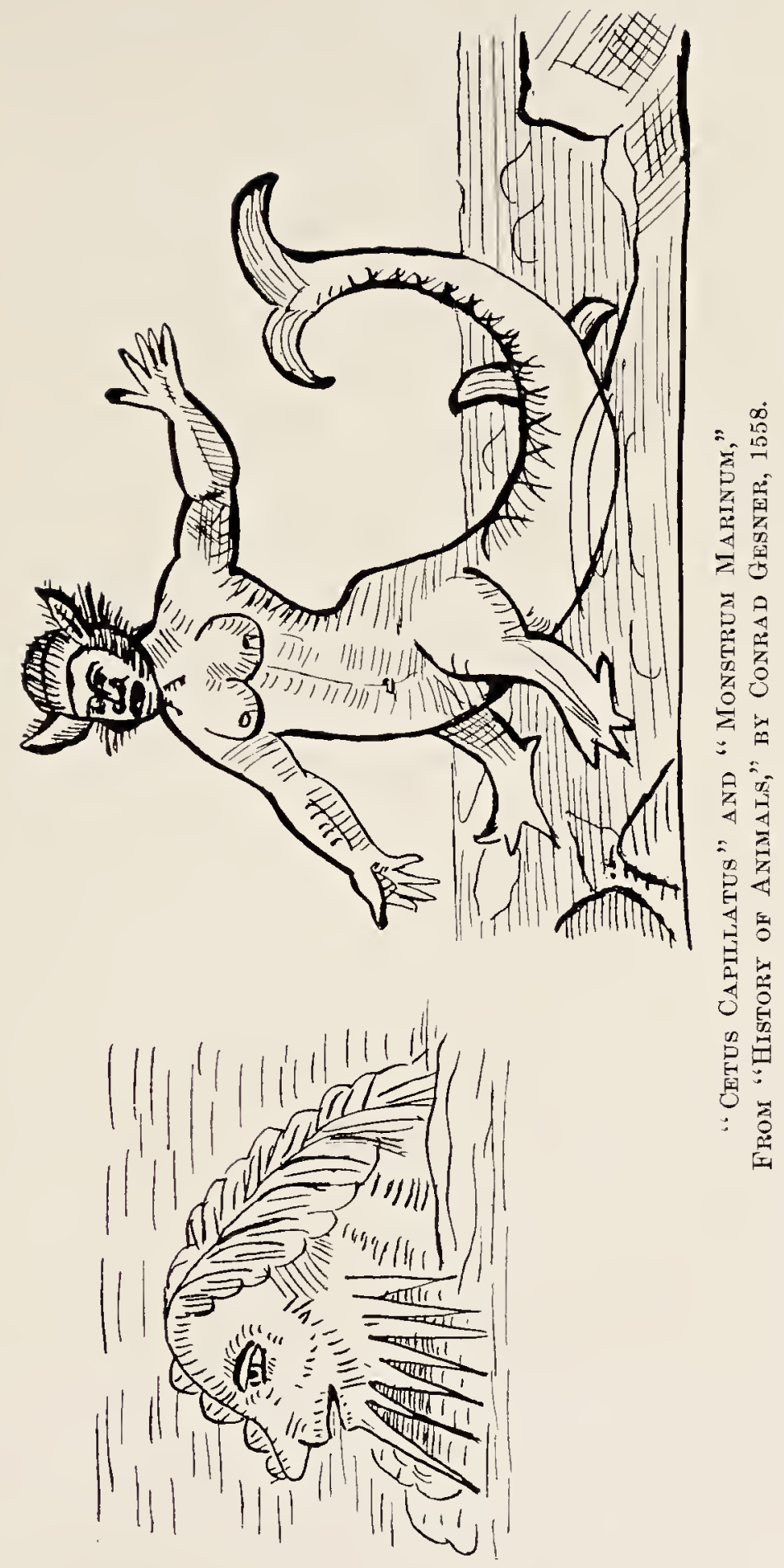





\section{THE HARBOR SEAL}

and speckled like a macrell. Their names that saw her were Thomas Hilles and Robert Rayner."

In those days it was a matter of common belief that mermaids existed, and it is not to be wondered at that Thomas and Robert saw one. I have sometimes reclined on a sand-spit on a warm summer's day, half in and half out of the water and found myself the center of interest of several pairs of seals' eyes, whose owners stretched up their heads, "looking earnestly on" me in a vain endeavor to determine what kind of a wateranimal I might be. In the dark swirl of the waters back of their heads I could easily imagine I saw "long haire hanging downe behinde," and as they went under water they frequently displayed their flanks and occasionally their tails and flippers " speckled like a macrell."

When in a hurry, or in the ordinary course of business, a seal pushes his head forward under water as he goes down, often following it by an upward roll of the back, but frequently, when in a leisurely mood, he deliberately points his nose to the zenith, and slowly draws it straight down under water. 


\section{SAND DUNES AND SALT MARSHES}

Sometimes he swims along the surface and occasionally displays the edges of his hindflippers above water.

The spirit of curiosity displayed by this animal is taken advantage of by seal-hunters, who conceal themselves in a blind, and, waving a handkerchief on a stick, sometimes succeed in beguiling a seal within gun-shot. Unfortunately a seal, when killed, almost always sinks, so that very few are recovered. They are afterwards cast up on the beach, and suggest from afar the whale factories of Labrador. Why dogs delight to roll in these unsavory derelicts is one of the unsolved problems of animal psychology. A picturesque instance of the curiosity of the seal, or possibly of its fondness for music, is interestingly told by the Rev. Mr. Dunbar in Macgillivray's work on British Quadrupeds: "During a residence of some years in one of the Hebrides, I had many opportunities of witnessing this peculiarity; and, in fact, could call forth its manifestation at pleasure. In walking along the shore in the calm of a summer afternoon, a few notes from my flute would bring half a score of them within a few yards of me; and then they would swim about, 184 


\section{THE HARBOR SEAL}

with their heads above water, like so many black dogs, evidently delighted with the sounds. For half an hour, or, indeed, for any length of time I chose, I could fix them to the spot; and when I moved along the water's edge, they would follow me with eagerness, like the Dolphins, who, it is said, attended Arion, as if anxious to prolong the enjoyment." It is related that when the bell is rung for divine service in the church of Hoy in Orkney, all the seals gather about the neighboring shore, an incident, however, that illustrates their enquiring, rather than their religious, spirit.

I myself have attempted the Arion rôle by singing "My Country, 'tis of thee" without producing any impression on the seals, favorable or unfavorable. Perhaps they did not recognize my efforts as music, and it is possible that I should have adopted the methods used by a naturalist in Jamaica who, it is said, when a boy, wishing to entice some snakes from beneath a rock by the power of music, marched around it beating a tin can and singing his favorite hymn, "Hark my. soul, it is the Lord.",

In exceptionally calm weather, when there 185 


\section{SAND DUNES AND SALT MARSHES}

is no sound of surf or of wind, one may sometimes hear the voice of the seal on Ipswich bar. It is a prolonged sound,-not a short bark,-a raucous, grating roar.

While seals generally sleep on the sandbars and rocks, they also appear at times to sleep in a delightfully lazy manner while floating in the water. With nose sticking straight up, their white moustachios pointing diagonally downwards, and eyes tightly closed, they float about, swaying up and down like a buoy with the waves, which occasionally submerge them, or cover all but the tips of their noses. Only for half a minute do they remain thus, for they soon bring their heads to the usual horizontal position and open their eyes, only to sink again into their zenith-pointing doze. Occasionally they gape and display great pink caverns, but relapse at once into sleep on their waterbed.

Although seals usually oceur only on the sea side of the dunes, not infrequently one or more may be seen in the water's of the tidal estuaries and rivers, up which they ascend a considerable distance and at a rapid rate with the rising tide. I have seen as many 186 


\section{THE HARBOR SEAL}

as a dozen of these animals drawn up together on the muddy edge of the marsh.

Birds and animals are all too generally classified by their power of working for man or of serving him as food or for clothing,-by their value in dollars and cents. As I was watching a flock of herring gulls circling with exquisite grace, and alighting like feathers on the Charles River Basin in Boston, I heard a teamster ask another what they were and whether they were good for anything. As his friend characterized them as entirely worthless, the men paid no further attention to them. They would have been utterly unable to understand the sentiment expressed by Thompson Seton, a sentiment that I am sure well applies to the seal: "I would preserve it, and a hundred others, even as I would preserve a beautiful picture, or view, for the unsordid joy of feasting the eyes on a sentient fellow creature, that is a little pinnacle on the cathedral of evolution, and glorious as an exemplar of beauty in the wild way of life." 


\section{CHAPTER VIII}

\section{SALT MARSHES}

"Dear marshes! vain to him the gift of sight Who cannot in their varied incomes share,

From every season drawn of shade and light, Who sees in them but levels brown and bare;

Each change of storm and sunshine scatters free

On them its largess of variety,

For nature with cheap means still works her wonders rare."

- LOWELl.

A RECENT writer on the geology of salt 1 marshes says: "As scenic features they are monotonous and uninteresting in the extreme because of their lack of relief and uniformity of appearance." To such one can but reply in the words of Lowell quoted at the head of this chapter.

While there is a peculiar charm of the sand dunes, so also is there a charm of the salt marshes-a salty flavor all their own. At all seasons there is a pleasure in their contemplation, and a joy in their exploration, 188 


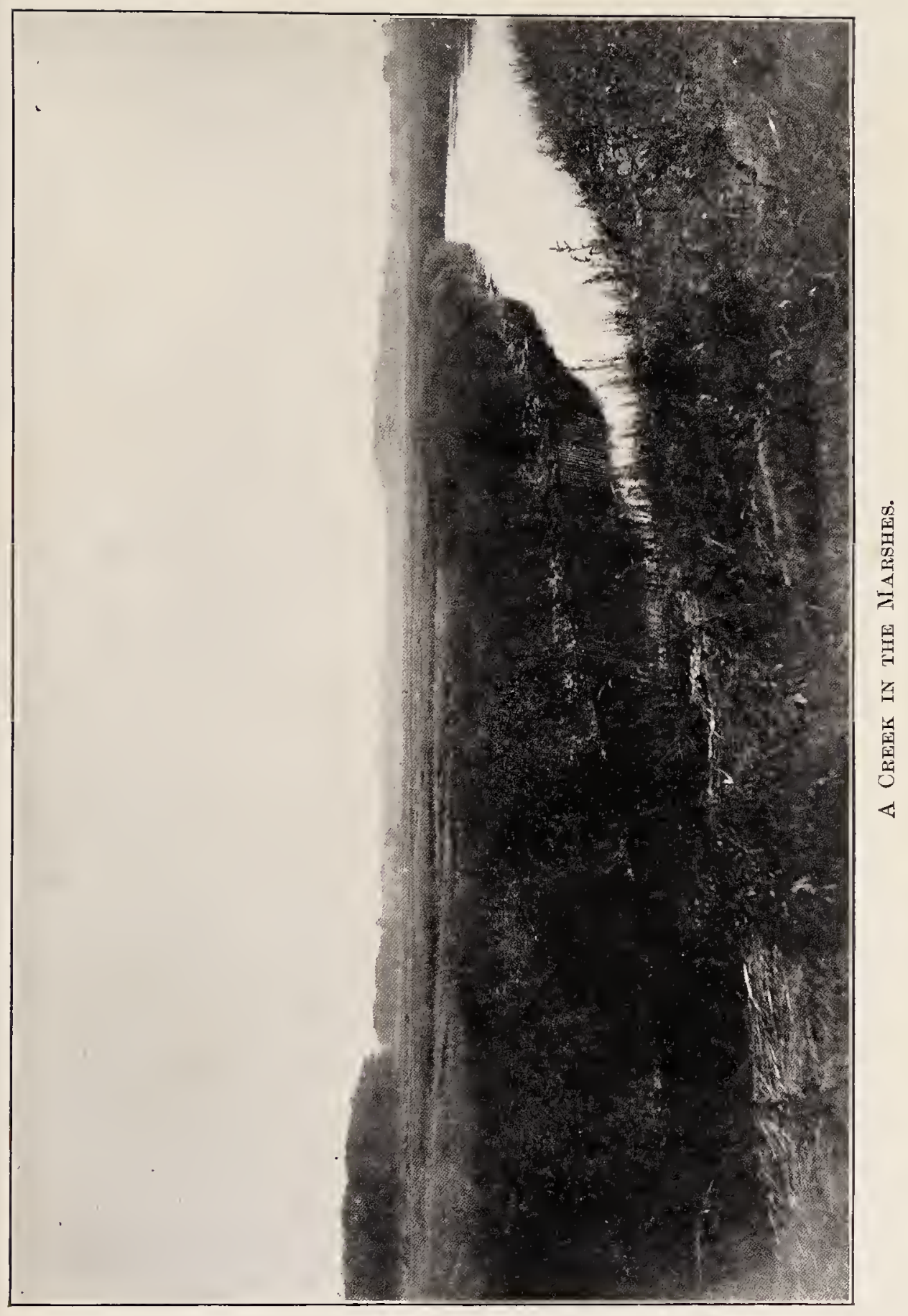





\section{SALT MARSHES}

whether it be in canoe or sail boat along their winding water-ways, or on foot over their treacherous surface.

Whether one looks from the elevation of a marsh island on these great level floors, extending for miles into the land, framed by the white sand dunes on the one side, by the dark hills on the other, or loses oneself in their midst, one feels with Sidney Lanier that

" 'Tis here, 'tis here thou canst unhand thy heart And breathe it free, and breathe it free, By rangy marsh, in lone sea liberty."

I can heartily agree with Coventry Patmore, who, in writing of the Sussex marshes, says: "The beauty of these marsh views is beyond all description, and has never been expressed even in painting. ... I have looked upon these marshes year after year and always with new delight."

There is a restful and satisfying character in marsh views which grows with acquaintance. One never tires of them, perhaps because they are never the same, and because they are even more changeful than the restless sea. Looking out on the broad bosom of the 189 


\section{SAND DUNES AND SALT MARSHES}

marshes one cannot be lonely, if the sense of their beauty is in the heart.

As in the sand dunes, so here in the marshes one's enjoyment of the beauty of the surroundings is not impaired but rather enhanced by an intimate knowledge of the life there. It is well worth while to study first the vegetation which plainly groups itself into four zones. Fortunately for the unbotanical, the hostile power of salt is such that it makes friends with but few plants, and these are easily learned. Lanier doubtless did not refer to botanical simplicity when he said:

"Ye marshes, how candid and simple And nothing-withholding and free, Ye publish yourselves to the sky and offer Yourselves to the sea!"

but they are good lines and will do here.

The lowest zone of all from the point of view of sea level is the zone of eel grass, a plant which belies its name and station, for it is not a grass nor even a seaweed, as is often supposed, and is not lowly, but is a member, albeit a humble one, of the lofty group of flowering plants, where it is placed above the pines 


\section{SALT MARSHES}

but below the grasses. The flowers are small and are hidden in the sheath-like base of the leaves, which, in narrow ribbons but a quarter of an inch wide, wave in long thickly matted streamers in the channel beds, and shelter in their shady forest groves snails and worms, crabs and eels. While living, the eel grass is a good friend to these creatures, and dead and cast up on the marshes or beaches it serves many a useful purpose. Under its sheltering windrows the sharp-tailed and Savannah sparrows build their homes, while the oriole, red-wing and robin weave it into their nests; the gunner stacks it up into a blind, in front of which he places his decoys to beguile the wandering shore-birds, and the clammer, fisherman and farmer pack it about the foundations of their houses to keep out the frost and the winter winds.

The next plant zone is equally simple and also limited to one species, the thatch grass, that grows from within two or three feet of low-tide level to the level of the ordinary high tide. Where the marsh is built up so high that it ceases to be washed by every tide, then the thatch ceases to grow, for it needs daily contact with old ocean. It is replaced by the 


\section{SAND DUNES AND SALT MARSHES}

vegetation of the third zone. The thatch is a sturdy grass, a wonderfully strong but pliant fringer of the creeks. It grows from two to five or even six feet high, and bears great waving plumes of simple straw-colored flowers and seeds. One always sinks into soft mud when struggling through it, for it is a great builder-up of the marshes and holds the fine detritus among its stalks and roots. The thatch is prized for bedding and for mulch, but most of that which is cut is carried off by the tides before it is harvested, and that which escapes the scythe is broken off by the ice and lines the edges of the marsh in great windrows,-not a spear is left standing after the winter. As a mulch for trees or shrubs it has no equal, for it is of course entirely free from weed seeds, and with the spring it disintegrates and loosens and enriches the soil.

The third zone is that of the salt-grass or marsh hay proper. This constitutes the firmer part of the marsh, reached only once or twice a month by the tides, where one may walk fairly dry shod if he instinctively and from long practice knows how to avoid embryo creeks, concealed ditches and treacherous sloughs, - the good old name used by Bun- 


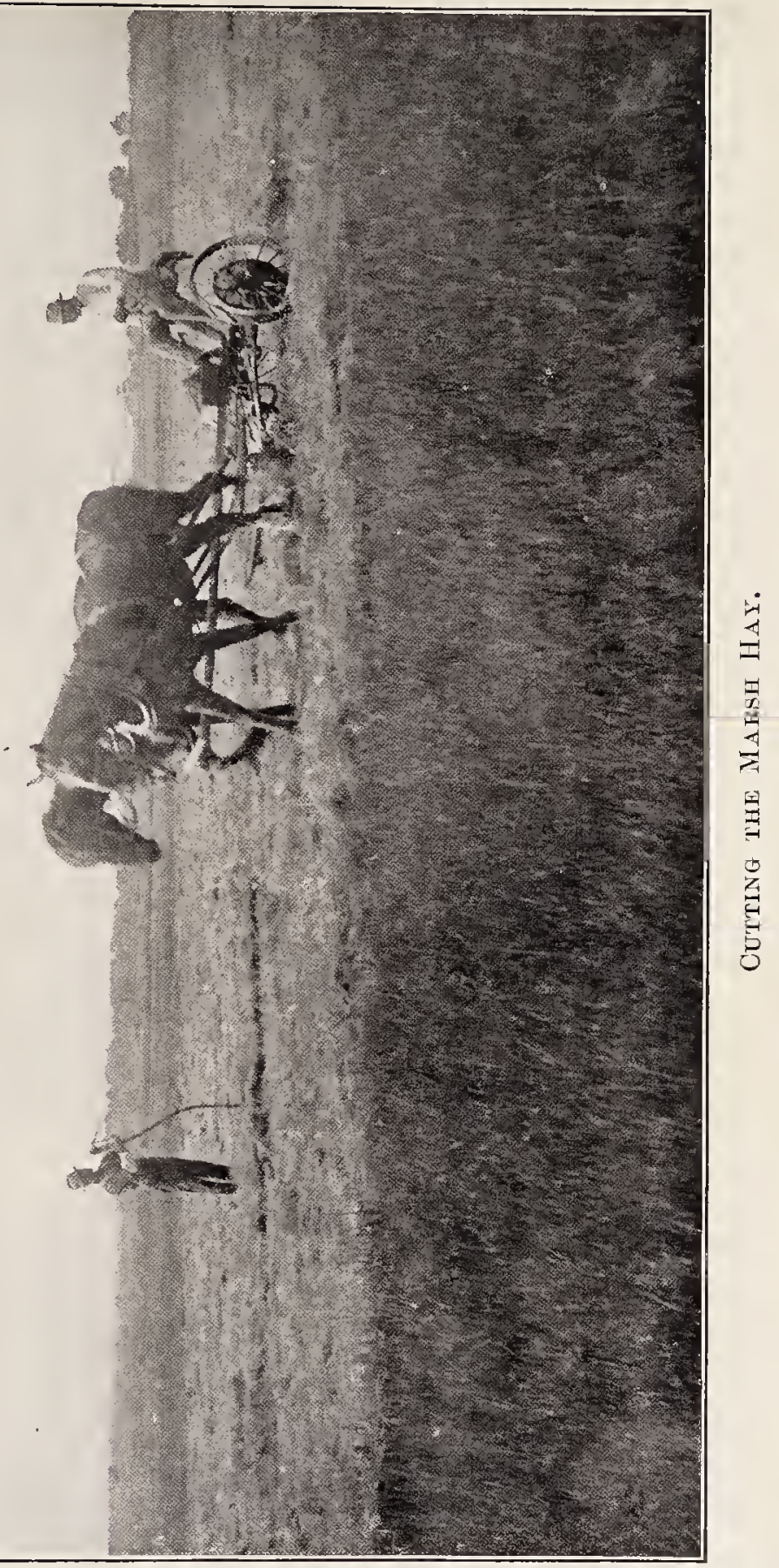





\section{SALT MARSHES}

yan is still common parlance in these old New England regions. The tenderfoot may suddenly sink to his hips in a draining ditch, overgrown at the surface, while the experienced may walk about safely.

The flora of this region is more varied, although most of the ground is covered with but three grasses:-a short slender relation of the thatch, sometimes called fox grass, a seaspear grass and a spike grass. None of these grows much beyond a foot in height. These three are the chief components of the marsh hay, which in this era of the gasoline engine is not so assiduously and thoroughly harvested as in the days gone by.

In cutting the grass, which is done in August at periods of a low run of tides, mowing machines are used, except in the lower, softer places, where the scythes are swung. The horses wear broad, wooden marsh shoes, and a novice horse is practised in the security of the barn-yard with the awkward, clanking things before he is ventured on the unstable marsh. It is no trifle for a pair of horses to become mired in the salt marsh, and only those men born and bred to the work can manage them in that treacherous region. The hay 


\section{SAND DUNES AND SALT MARSHES}

is piled in small cocks, under which are thrust two long poles. These serve like the handles of a Sedan chair for the removal of the hay to the higher land beyond the reach of the tides.

Hay boats, or canoes as they are inappropriately called, are also used to harvest the hay. These are long, narrow, flat-bottomed, square-ended scows that work in pairs covered with a broad platform, on which the hay is piled. With great sweeps, long unwieldy oars, the haymakers slowly urge them along the winding creeks, while the steersman, with a huge oar resting on a supporting oar-lock in the stern, directs their course. In many places the hay is piled in huge stacks, that are elevated above the highest tides on small piles or " staddles," as they are called, and the stacks dot the marsh for miles like clustered tents. When the marsh is fast bound by winter frost the farmer goes his rounds and carries off the savory, salty hay on sledges, his horses' iron shoes now well sharpened. No need of wooden marsh shoes; all is hard and solid as the rocky ledges.

Nearly all the farms of this region, even those several miles from the marshes, have 194 


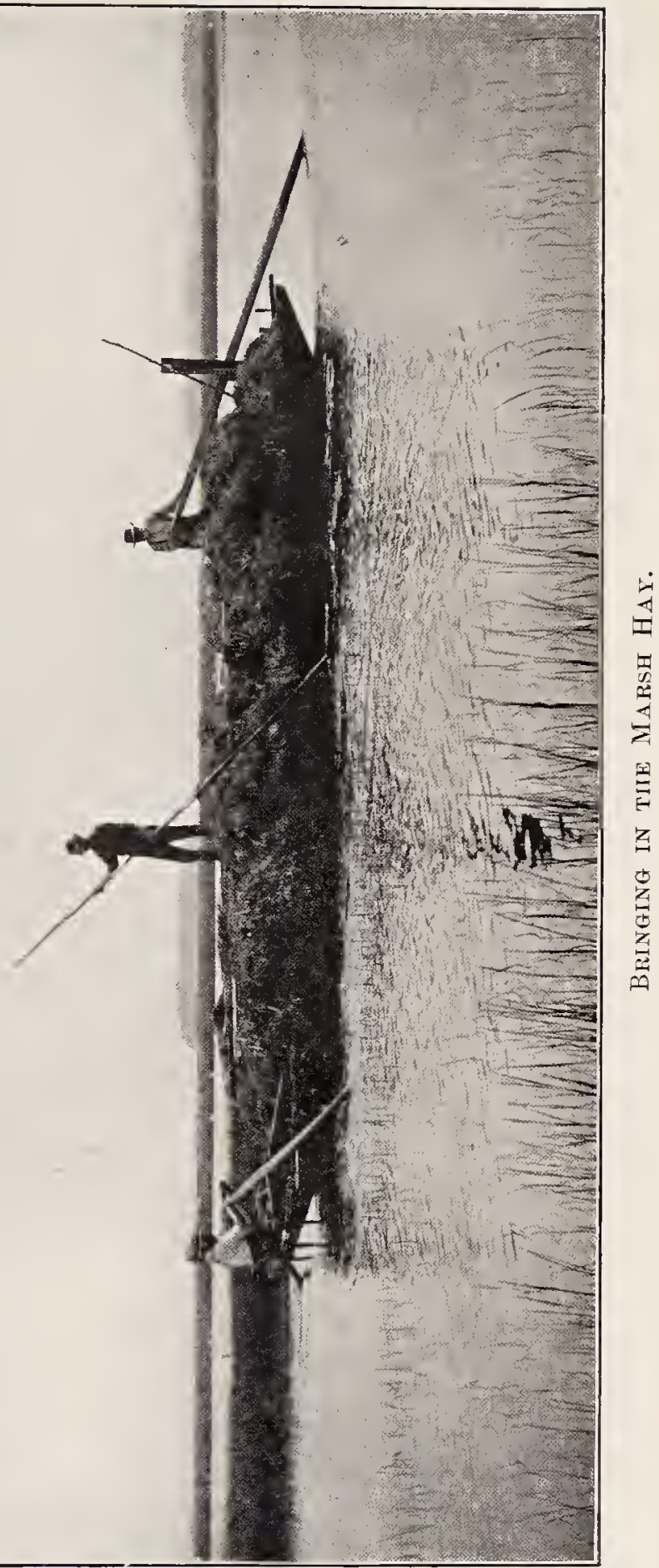





\section{SALT MARSHES}

their patches of salt marsh, each reached by an ancient right of way. Most of the marsh hay is fit only for bedding, but when cut at the proper season and carefully harvested it makes valuable fodder for cattle.

Besides the fox, sea-spear, and spike grasses of the broad marshes, one comes on patches of a salt marsh sedge, which, with its sturdy brown bunches of fruit, grows in protected regions, while the seaside plantain with its narrow grass-like leaves is common everywhere. Another plant with narrow leaves, and therefore mistaken for a grass and called arrow grass, is common in this zone.

Perhaps the most striking plant, when it emerges from its inconspicuous green of summer, and changes in the fall to a modest red and later to a flaming scarlet, is the glasswort or samphire, a plant of universal distribution in salt marshes, both in this country and in Europe and Asia.

The sea milkwort, a humble saline member of the primrose family, surnamed glaux from its sea-green color, bears tiny flowers of pink and lavender, and grows prostrate or erect among the grasses.

Another marine plant of the salt marshes 195 


\section{SAND DUNES AND SALT MARSHES}

- four in this small company rejoice in the specific name maritima-is the seaside gerardia, which has little rose-purple fox-gloves on its slender stalks. But the most prominent flowering plant of this region, and one that forms great nosegays of tiny lavender flowers in delicate interlaced sprays, is the marsh rosemary or sea lavender. This is a sturdy perennial with a clump of oblong leaves rising from the root, and it is one that blossoms from July to September.

The fourth and highest zone,-the fringing edge where it joins the upland, - a region that is visited only by the unusual spring and autumn tides, or when easterly storms reinforce the moon, is the black-grass zone. This zone averages from half a dozen feet to as many yards in width, but may extend over many acres that are shut out except from the highest tides. The black-grass also occurs as islands elevated slightly above the level of the general marsh. This black-grass, the main component of the zone, is so called because of its dark color, which looks almost black when the plant is in fruit. It is a rush, however, and not a grass.

Extending down into the black-grass grow 196 


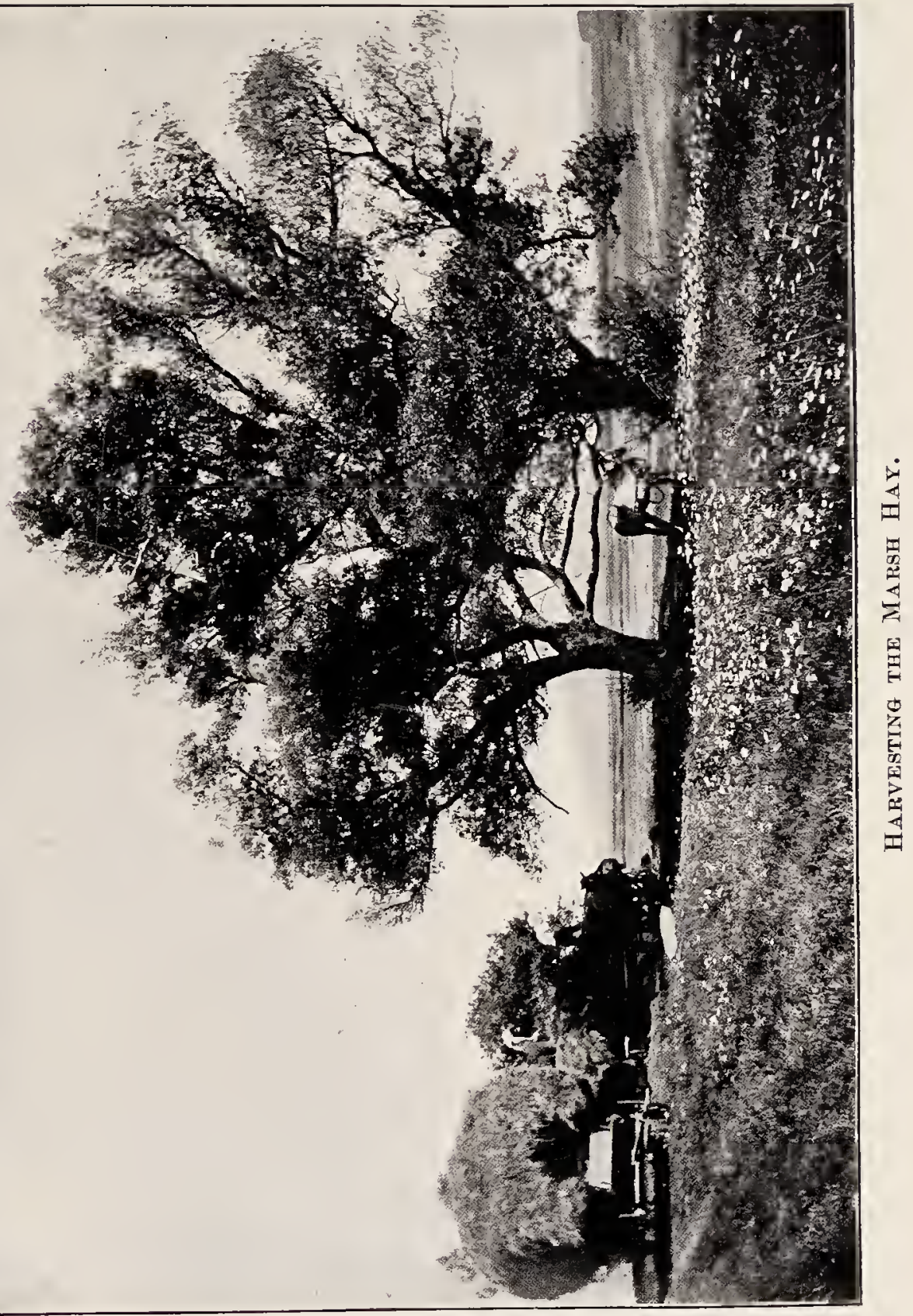





\section{SALT MARSHES}

clumps of the handsomest of all the goldenrods, the seaside golden-rod, while the silver weed abounds in places, and the delicious sweet-grass can occasionally be found on its border's. I have attempted to measure the vertical range of the last three of these four zones, and have found that the thatch ranges through approximately six feet, extending from within about three feet of low-water mark to the lowest high-water mark; that the zone of marsh hay ranges vertically about two feet, while the zone of blackgrass has a vertical range of only about a foot.

All the marsh vegetation is at its height of luxuriance in mid-August. Then the marsh lies brilliant in the sunlight, a broad expanse, flat as a floor and glowing in yellow-greens, touched here and there with washes of buff and of chestnut.

Fringing its upper edge is the broad band of the mourning black-grass, while the rich dark green of the thatch threads invisible serpentine creeks, and borders the ribbons of water that wander hither and thither like tortuous veins through the marshes, reflecting the brilliant blue of the skies. There are wonderful plays of light and shade as cloud shad- 


\section{SAND DUNES AND SALT MARSHES}

ows chase each other over the surface of the marshes, or as the lengthening shadows of the hills extend their range with the declining sun. On windy days the tall thatch bends before the blasts, and shimmering waves like those on the surface of the water pass over it.

On such days, with the wind in the northwest quarter, the air is exceedingly clear, and every wooded island and distant hill stands out with great distinctness, while the creeks take on an intense blue which contrasts strongly with the light green of the marshes.

The tides creeping over the sand flats, swelling the creeks, obliterating the brown banks and drowning the tall thatch, bursting out in unexpected veins and pools throughout the marshes,-all this, notwithstanding its twice daily repetition, is never other than a miracle.

" My holes were empty like a cup,

In every hole the sea came up,

Till it could hold no more."

And when at the full of the moon in the night, the sea spreads silently over the broad marsh, reflecting the silvery light in the sky, the miracle is at its height! 


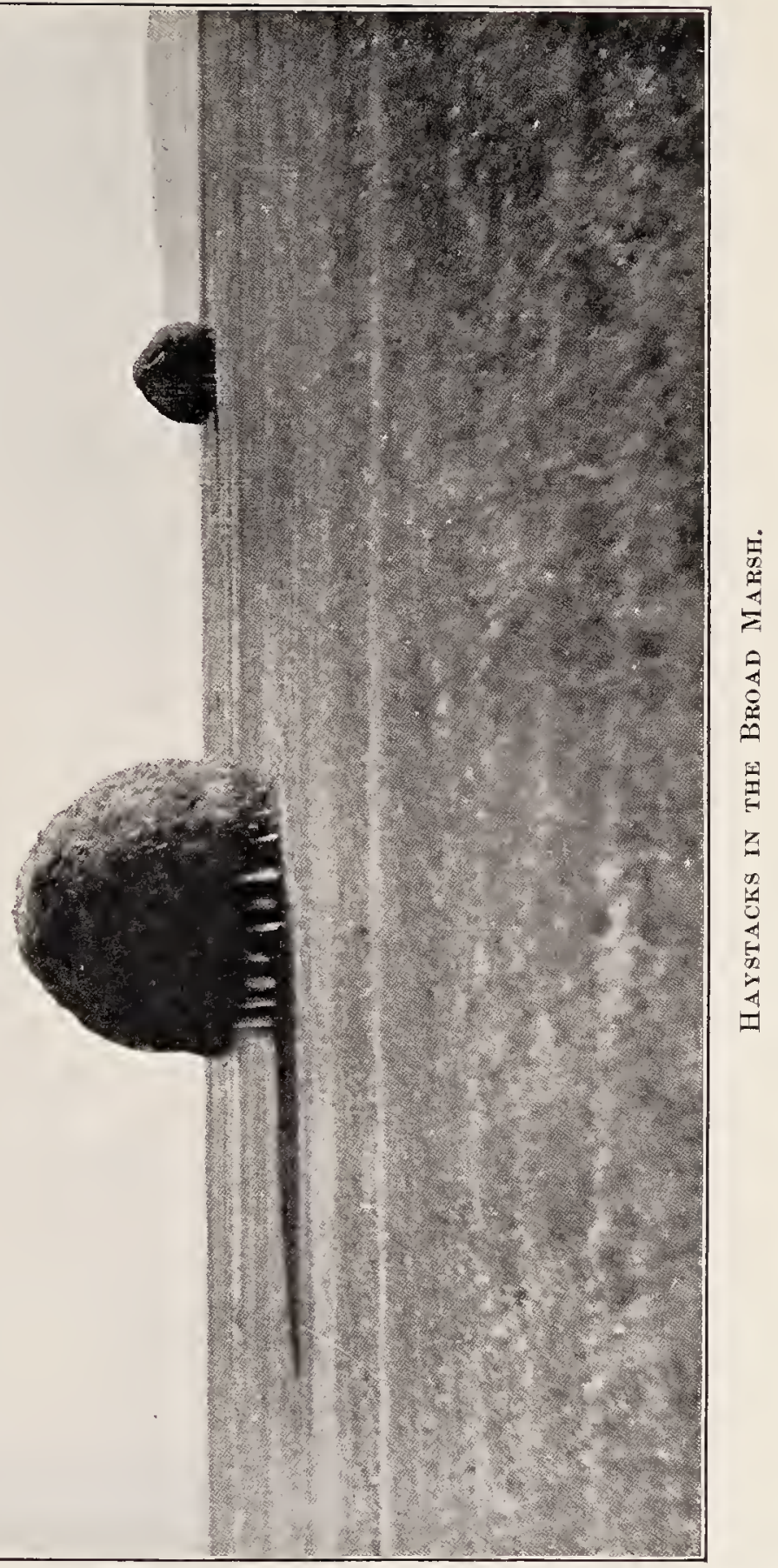





\section{SALT MARSHES}

"And the sea lends large, as the marsh: lo, out of his plenty the sea

Pours fast: full soon the time of the flood-tide must be: Look how the grace of the sea doth go

About and about through the intricate channels that flow Here and there,

Everywhere,

Till his waters have flooded the uttermost creeks and the low-lying lanes,

And the marsh is meshed with a million veins, That like as with rosy and silvery essences flow

In the rose-and-silver evening glow

Farewell, my lord Sun!

The creeks overflow: a thousand rivulets run

'Twixt the roots of the sod; the blades of the marsh-grass stir;

Passeth a hurrying sound of wings that westward whirr; Passeth, and all is still; and the currents cease to run; And the sea and the marsh are one.

"How still the plains of waters be! The tide is in his ecstasy. The tide is at his highest height:

And it is night."

Sidney Lanier was a true lover of the marshes, and saw and appreciated their every detail. And again:

"The tide's at full: the marsh with flooded streams Glimmers, a limpid labyrinth of dreams. 


\section{SAND DUNES AND SALT MARSHES}

Each winding creek in grave entrancement lies A rhapsody of morning-stars."

The ebbing tide is as wonderful as the flood: and the sunrise is as wonderful as the sunset.

"But the air and my heart and the earth are a-thrill, And look where the wild duck sails round the bend of the river, -

And look where a passionate shiver

Expectant is bending the blades

Of the marsh-grass in serial shimmers and shades, And invisible wings, fast fleeting, fast fleeting,

\section{Are beating}

The dark overhead as my heart beats, — and steady and free

Is the ebb-tide from marsh to sea -

(Run home, little streams,

With your lapfuls of stars and of dreams), And a sailor unseen is hoisting a-peak, For list, down the inshore curve of the creek

How merrily flutters the sail, And lo, in the East! Will the East unveil? The East is unveiled, the East hath confessed A flush: 'tis dead; 'tis alive: 'tis dead, ere the West Was aware of it: nay, 'tis abiding, 'tis unwithdrawn: Have a care, sweet Heaven! 'Tis Dawn."

To float down in a canoe with the ebb tide, to explore the narrow channels now sunk deep 200 


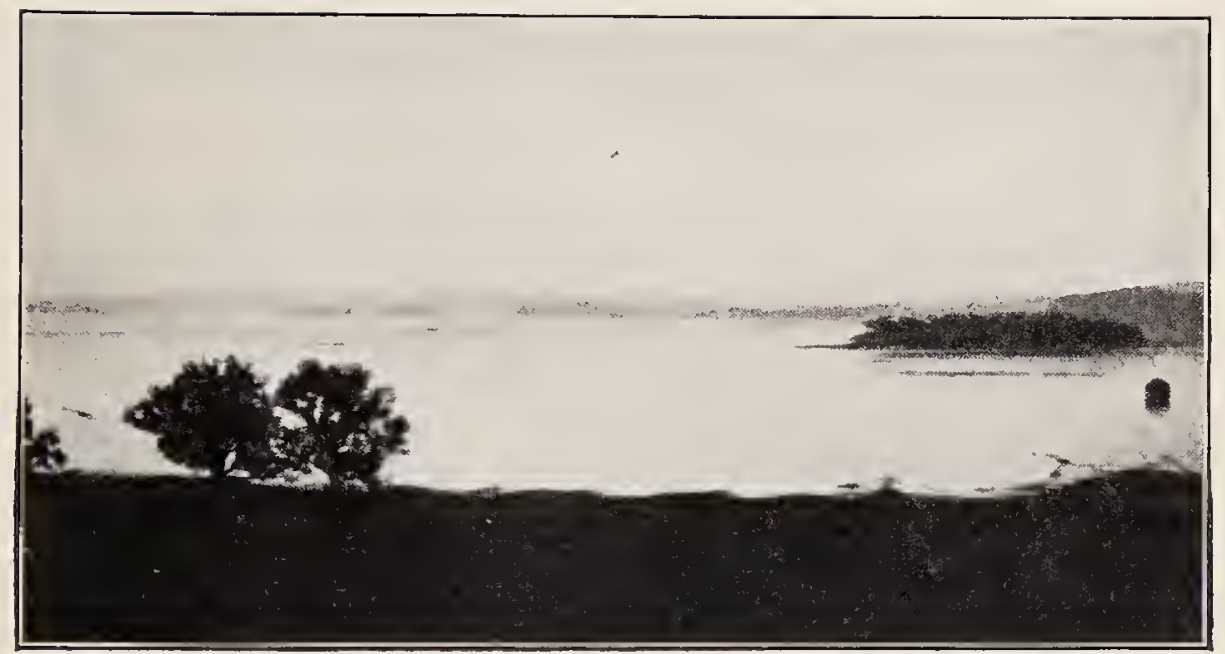

High Tide - Taken by the Light of the Full Moon.

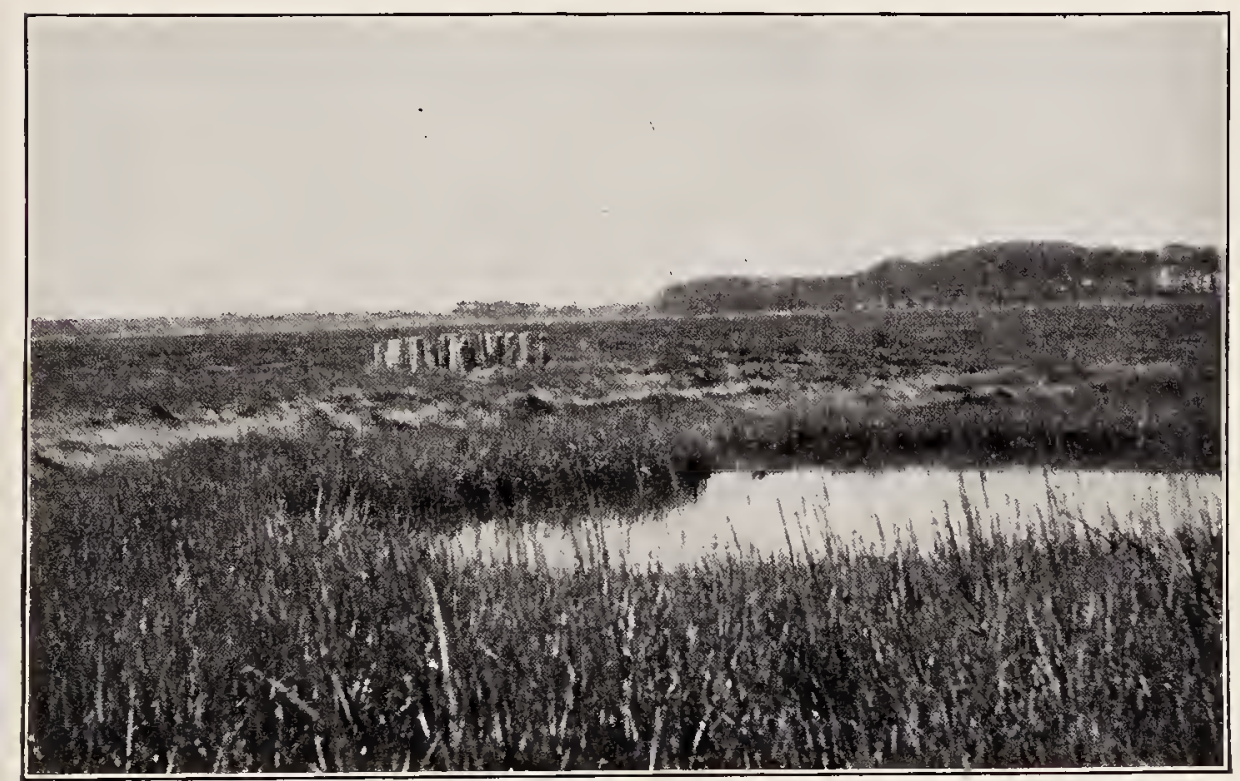

A STAddie iN THE MARSH. 



\section{SALT MARSHES}

below the marsh level, to surprise the marsh birds on the broad sand and mud flats, to push over the waving forests of eel grass with their varied inhabitants, affords much enjoyment, and opens up an entirely different world from that of the same water courses when they are brimming over on to the marsh. Partly from prejudice, partly from ignorance, dead low tide is not appreciated as it deserves. The clean sand of the estuaries and the fine mud of the smaller creeks and inlets, and the clear water of the sea, are all very different from the foulness to be found at low tide in the neighborhood of sewer-discharging cities.

In the fall of the year the marshes take on a yellowish brown color, varying in different lights from silvery yellow to russet-brown, threaded in places with bands of light peagreen, in places with dingy red, while the samphire, hitherto invisible in its common green, blazes out in broad crimson patches. Still later in the year before the ice and snow cover it all, the marshes wear a uniform russetbrown livery, a restful, neutral brown shade, a shade that hair and skin and clothing alike of all marsh dwellers assume in time. Yet one finds places where the grass is a pale, almost 


\section{SAND DUNES AND SALT MARSHES}

silvery gray, varying to straw color, and again to a rich chestnut, while rarely a patch of brilliant orange appears under certain conditions of light and moisture.

"Another change subdues them in the Fall, But saddens not; they still show merrier tints, Though sober russet seems to cover all."

Early in the morning in the wonderful days of Indian summer, when the whole east is aglow, the marsh is often white with hoar frost, and each grass blade that crunches under the foot sparkles as if beset with innumerable diamonds. As the sun rises from the sea, the white veil dissolves and tiny drops of water hang from every blade-tip.

Later in the year, with the creeks lined and for the most part coated with ice, with ice in all the pools and sloughs, the marshes in their patchwork dress of white and brown resemble ptarmigans that are moulting from summer to winter plumage.

Again the scene shifts, and winter with its white pall covers the marsh. The creeks are fast bound, but expand and contract their groaning bosoms with the flood and ebb. At 202 


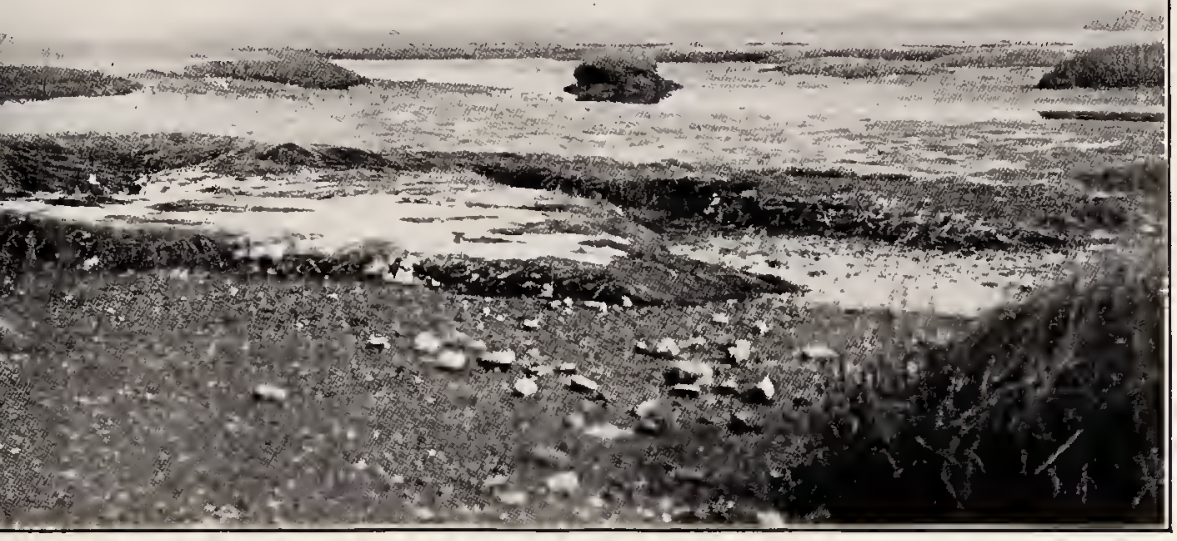

Low TIDE.

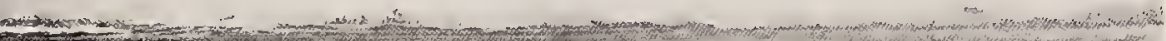

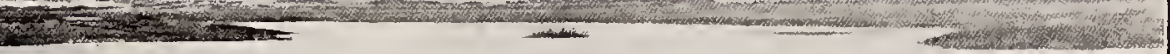

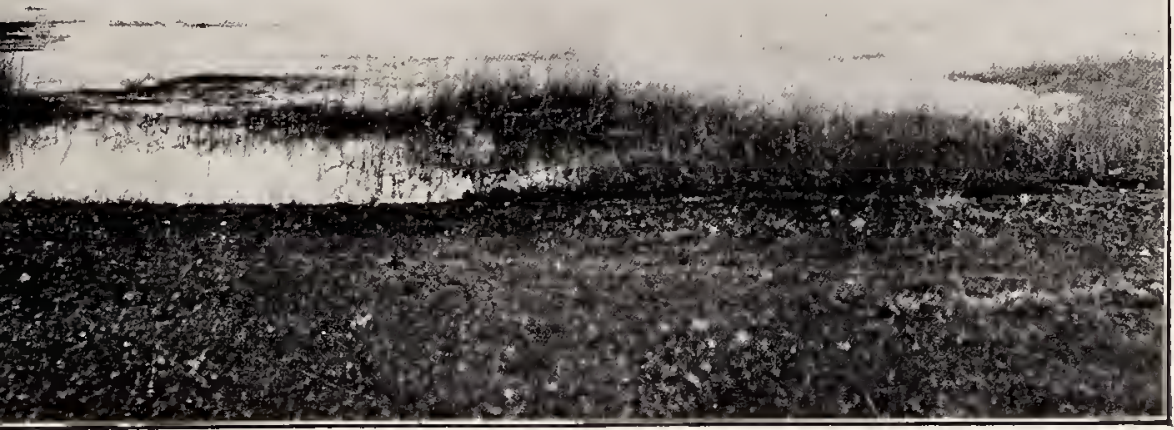

$$
\text { (2) }
$$

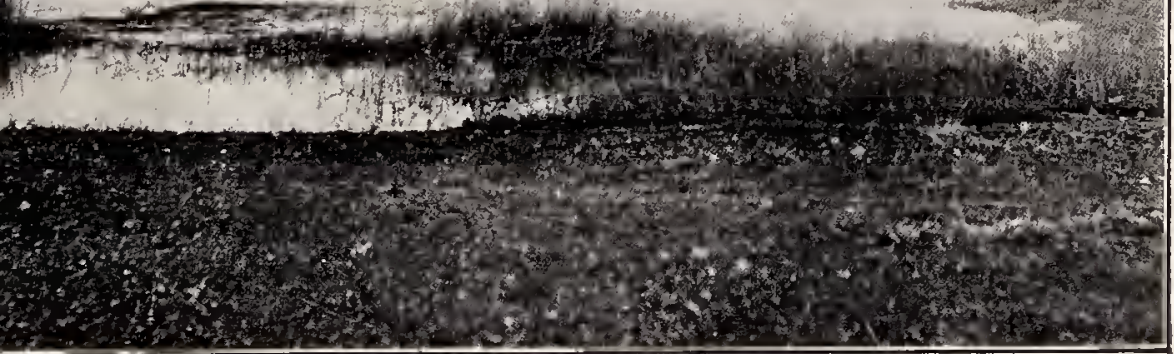

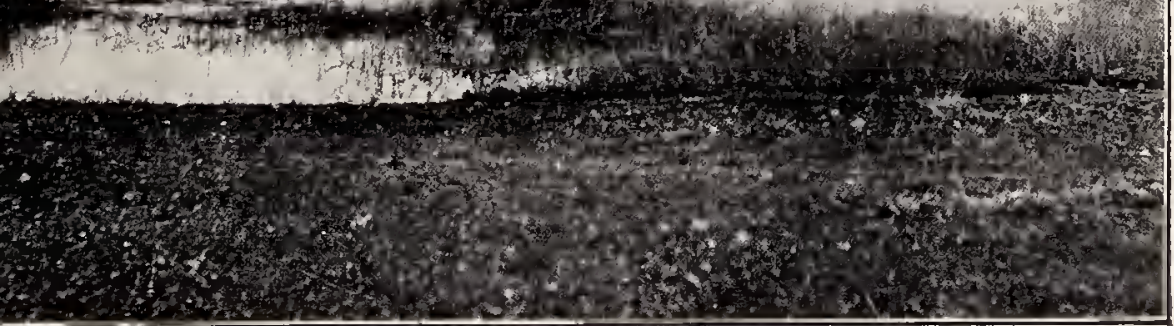
and High TIDe. 



\section{SALT MARSHES}

times all is smooth and white except on the borders of the creeks, which mark their tortuous courses by eruptive blocks of ice, so dark in the shadows that they stand out black and distinct. The smaller creeks are arched with ice, and the water comes and goes in concealed channels, but the main creeks and large estuaries are generally partly open and show patches of dark blue in contrast with the universal whiteness. In the times of the month when the moon and the sun pull together, or when the normal level of the tide is disturbed by fierce northeasters, the waterways burst their bonds with force irresistible, carrying all before them, and great ice cakes are tossed and piled about on the broad marshes. Between the stranded floes the poured-out tide freezes fast to the stubble, and each returning tide adds to the icy coating. The water flowing over the ice and collecting in pools assumes a pale green color that contrasts strongly with the surrounding whiteness.

In the sunlight the white salt ice sparkles and glitters with dazzling splendor, but the full arctic glory of the scene is brought out to best advantage in the still cold nights when 203 


\section{SAND DUNES AND SALT MARSHES}

the moonlight permeates everything. Many such scenes have I enjoyed in times gone by when I hunted the black duck by moonlight, and I think I may be forgiven when I confess that I never succeeded at Ipswich in shooting a single duck at this unholy time. The wonderful beauty of these nights well repaid the long cold vigils. Everything seemed as bright as day, and one felt sure that an object as large and dark as a black duck would easily be visible. Yet many a time ducks have flown by so closely that their wing strokes whistled loud in my ears, but peer as I might, they remained invisible, unless perchance they flew across the moon or its beams reflected from the ice or water.

All things come to an end in time, and the last ice cake, honeycombed and darkened with sand and mud gathered on its journeyings to and fro, vanishes, and the marsh is left brown and prostrate from its winter's battle. All the graceful thatch is broken off and lines the edges of the uplands in great mats, and the mud where it grew is open to the sky. Spring has long visited the uplands, soaked in fresh water from melting snow and spring rains, before it awakens the salt marshes. These 204 


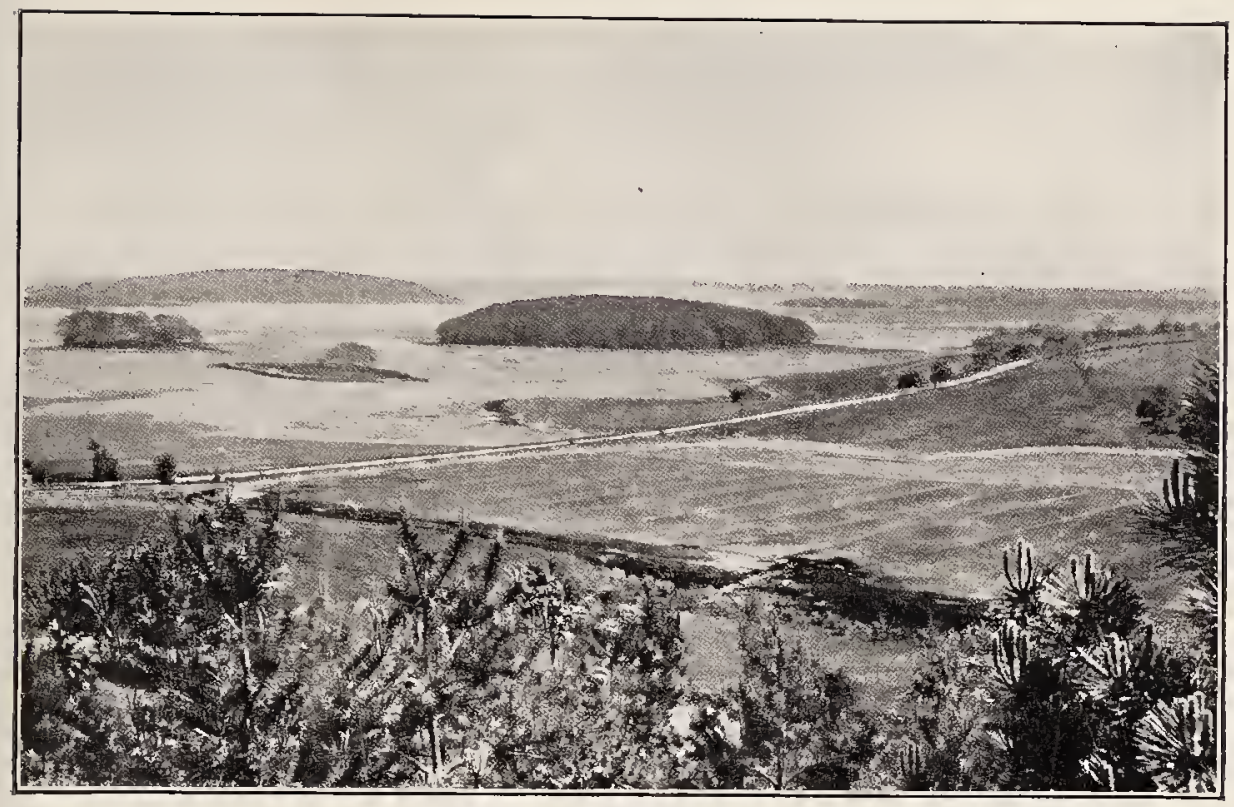

Marsh Islands.

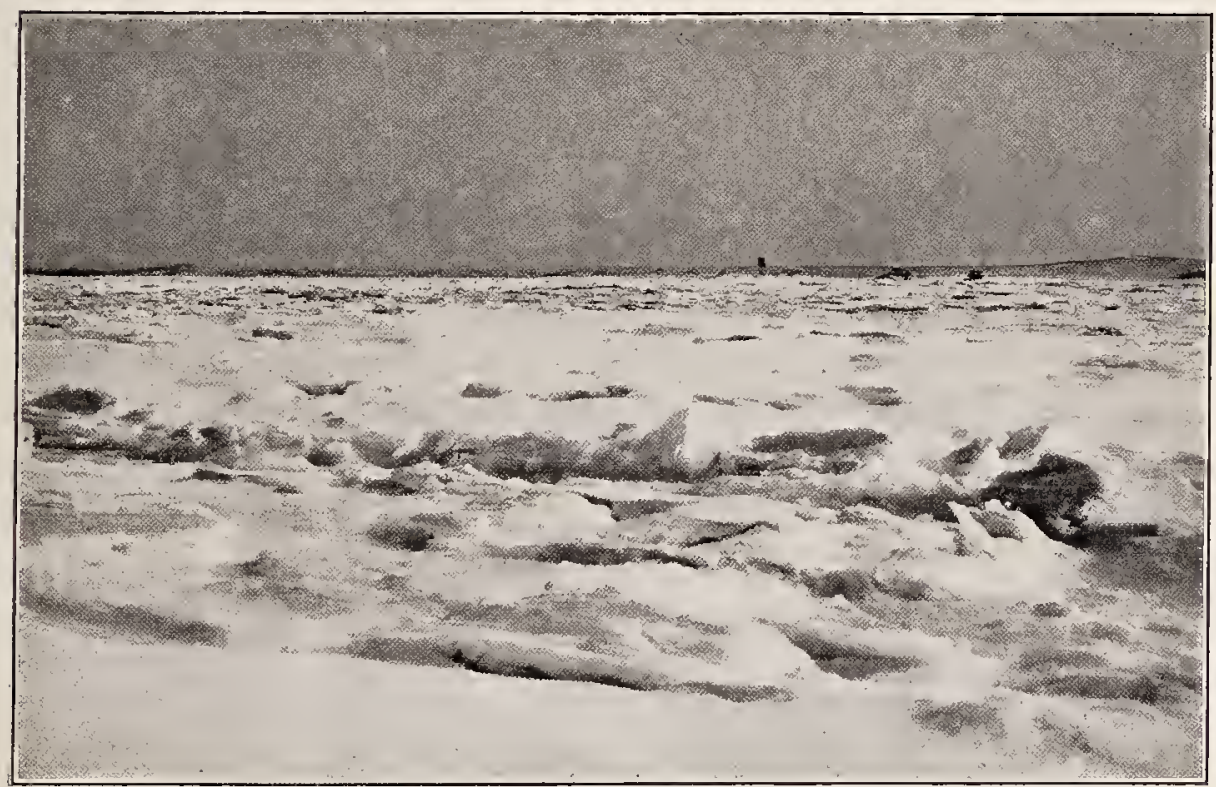

The Marsh ix Winter. 



\section{SALT MARSHES}

emerge from their winter mantle a uniform drab or yellowish-gray, lighter in the sunlight and darker in the shadow.

When the tender leaves of the willow are first showing, early in May, and the dog'stooth violets are spreading their yellow carpets on the islands, the marsh shows its first sign of returning life by patches of dark green in the black-grass zone. A little later and a tinge of pale green appears on the borders of the creeks, where the thatch is sending up a few sparse sprouts. By the middle of May the creeks, large and small, are edged with the pale green of the young thatch, a green with much yellow in it, while the black-grass is now even darker than before and has taken on a bluish tint. Only here and there in the great middle zone is there a suspicion of pale green in the universal drab, but by the first of June this pale greenness has spread in bands and patches over the marsh, and has become dark green interspersed and tinged with the drab of the old rowan. And so the seasons come and go and the marsh is always beautiful. 


\section{CHAPTER IX}

SALT MARSHES - THEIR PAST AND FUTURE

"O, call back yesterday, bid time return."

- Shakespeare.

T $\mathrm{N}$ a study of the past it is convenient to have some definite point from which to date. To the original settlers on these shores Noah's flood was a very real catastrophe, in which everything on the earth was washed clean, and, by a reference to the Bibles of those days, or even to the Bibles of fifty years ago, one may learn that this flood occurred 2,349 years before Christ. To our forefathers the time that had elapsed since the flood was a long period to contemplate, but nowadays we are contented to look upon the fifty thousand years more or less, since the last glacier left these shores, as a mere moment of time in the great past. There is no doubt that the glaciers compared favorably with Noah's flood in cleansing power. Every206 


\section{SALT MARSHES-PAST AND FUTURE}

thing of an animal and vegetable nature has come in since then, including the salt marshes themselves, which are made up of various growing grasses on top, and, in their entire thickness of closely woven sod and thick black soil, they are largely of vegetable origin. One must picture this region at the close of the glacial period, therefore, as entirely destitute of the most striking feature of to-day, a region of brown land and blue water, but lacking the great blanket of green marsh.

As one looks inland from the Ipswich dunes over the broad plain of salt marshes, the rounded form of Hog Island-the birthplace of Rufus Choate-looms up as a conspicuous object in the landscape. It is a typical drumlin, one whose duplicates are to be found everywhere in northern Europe and America, where the ice sheet of the last glacial period formerly held sway. It is a smoothly rounded accumulation of turf-covered gravel a hundred and forty feet high, somewhat steeper on the north than on the south side, but as featureless as an inverted punch-bowl. On the western side its curves are cut by the flat plane of the salt marsh. Scattered here and there in the marsh are to be seen lower 


\section{SAND DUNES AND SALT MARSHES}

rounded or oval islands, some of them covered with trees, while in the Castle Neck River is a small circular gravel island so low that it is all but overtopped at high tide.

Aside from the thin coating of soil and vegetation, Hog Island shows scarcely any evidence of change by wind, water or frost that have been acting on it since it emerged from the glacier's bed. We are indeed very close to the glacial period, and the interest in aretic life and adventure, an interest which is common among northern people, and extends even to the delicate of both sexes, is, perhaps, an inheritance from the times when glaciers spread far down among the homes of our ancestors.

" Some old gray witch that I cannot see

Has placed her charm in the storm and snow;

The Great White Silence is calling me,

The Long Trail beckons, and I must go."

Shaler in writing from Florida said: "The nearer I get to the tropies the more I turn with pleasure to our grim northern clime."

It is well that this love of the ice, which is often incomprehensible to those of southern 208 


\section{SALT MARSHES-PAST AND FUTURE}

ancestry, continues to exist, for who can say but that the glaciers of Greenland and Alaska and Spitzbergen, of the Alps and the Himalayas may not again wax and spread over regions now in the temperate zone? May it not be that the present is merely one of the interglacial periods which have occurred again and again during the ice age? Indeed, there is reason to believe that some of the interglacial periods of the past were even longer than the interval of time which has elapsed since the ice receded.

In order to picture the land as exposed by the receding glacier, we must not only strip off the salt marsh, as well as all other evidences of vegetable and animal life, but we must do more than this, for, as we shall see, there is every evidence of a former higher elevation of the land in relation to the water. There are also reasons for believing that as the land sinks, the marsh, soft and uncertain as it seems, is really more stable than the everlasting hills, and maintains itself at the same point.

Some of the low oak islands in the marsh are doubtless the tops of drumlins or of smaller glacial hillocks, as is shown by their 


\section{SAND DUNES AND SALT MARSHES}

circular or oval outlines and gravelly formation, while the round pebbly island in the Castle Neck River is of the same nature, but is now so nearly submerged, that all humus and land vegetation, as well as the finer particles of the top of the gravel hill, have been washed away in stormy tides, and nothing but boulders and sand is left.

If the land had remained at the same level as it was at the close of the glacial period, we should be able to discover some traces of ancient shore line where the sea waves formerly pounded, some old beaches with sub-fossil shells and crabs on and under the borders of the marshes, separated now from the sea by acres of green salt turf and by barrier sand dunes, which, like the marshes, are of recent formation. If on the other hand the land had risen at various rates, we should find a series of flat terraces or several elevated beaches, as on the Labrador coast to-day, where one sees two or even three beaches one above the other, some of them two hundred feet or more above the present sea level and almost as clean as when the surf beat on them. In this Ipswich region, however, there are no traces of old terraces or beaches, either at high tide level 


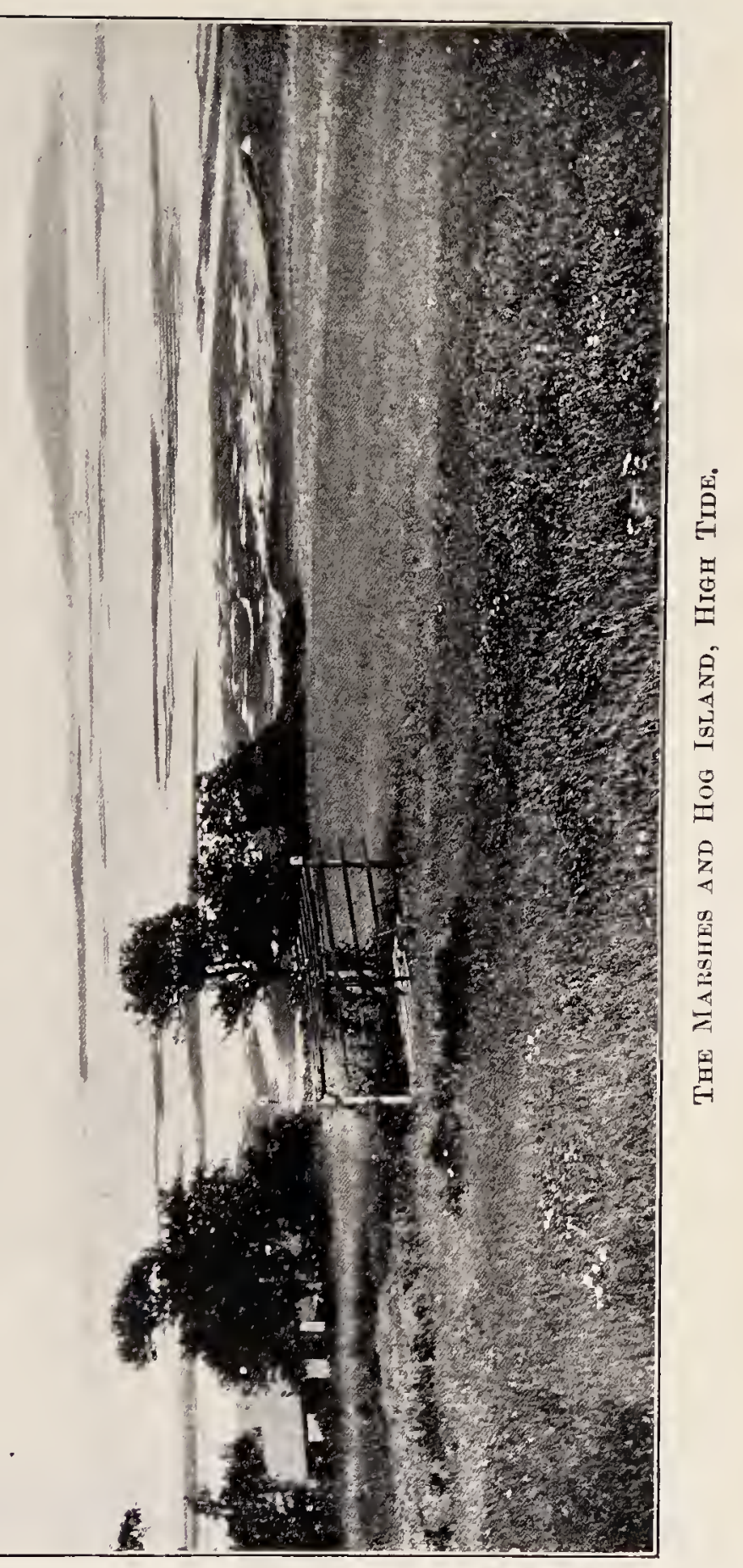





\section{SALT MARSHES - PAST AND FUTURE}

or above. Hence the land could not have been stationary or rising. One alternative alone remains, namely that the land has been slowly sinking, a process in which all landmarks are covered up or "drowned." Of course the same results would obtain if, instead of the sinking of the land, there had been a rising of the water, and the theory is held by some that the amount of water in the ocean was tremendously increased by the melting of the glaciers during their recession. It hardly seems possible that this would account for the difference in level which seems to have taken place during the last thousand years or so, at the same time that an opposite change has been taking place in Labrador. Be that as it may, if one stands at the top of Hog Island at high tide at the full of the moon, and looks out over the waste of waters extending several miles inland, flooding all the marshy valleys and making veritable islands of the drumlins, one is impressed with the force and accuracy of this term drowned.

At a number of places along the coast of Essex County the evidence of the changing level of the land is shown so plainly that he who runs or even swims may read, for there 


\section{SAND DUNES AND SALT MARSHES}

are stumps of forest trees still in position in leaf-mould and peat beds below the level of high water. In a cove near Bass Point at Nahant the stumps of white pine and white cedar, hemlock, spruces, ash, oak and maple are to be seen covered by thirteen to sixteen feet of water at high tide. In Lynn Harbor, and in the Saugus marshes, at Swampscott, Marblehead, Manchester and in Salem Harbor, these remains of submerged forests are also found, while near Misery Island, when the tide is low and the water still, stumps of forest trees may be seen at a depth of twelve to fourteen feet. In a marsh at Ipswich that is flooded by the great tides of the full moon of spring and fall, several stumps of great trees are to be seen imbedded in the salty peat. One of the old farmers told me that when he was a boy an old man used to say that his father remembered when this region, now filled by the black-grass marsh, was occupied by a grove of forest trees. Professor E. C. Jeffrey very kindly examined chips from two of these stumps for me, and found that one was a white pine, and the other a swamp white oak.

In 1804 and 1805 Dr. Nathaniel Bowditch 212 


\section{SALT MARSHES-PAST AND FUTURE}

prepared a chart of Salem and Marblehead harbors, giving the soundings over various ledges and rocks. Ninety years later, in 1894, careful measurements were again made at these same points and under similar conditions of tide and moon, by the late Professor John H. Sears. In all cases the water was found to be from one to two feet deeper than it was ninety years before. In 1903 Mr. John R. Freeman concluded that the land in Boston and vicinity was sinking at the rate of a foot in a hundred years by comparison with various ancient and modern tide gauges; also by the fact that the sills and floors of the masonry dry dock at the Charlestown Navy Yard then stood about nine inches lower relatively to mean sea level than they did seventy years before, while the dock stood at precisely the same level relatively to points on solid ground.

An incontestable evidence of a former higher land level is presented by the deep channels of all our eastern rivers, up which the tide rushes for many miles, and by the fact that these channels extend for a long distance out to seaward under the water. Only when the land stood at a much higher level could these channels have been cut. 


\section{SAND DUNES AND SALT MARSHES}

Another strong evidence of subsidence is shown in a study of the sections of the marshes, for, as we have seen, the various species of grasses are limited to certain zones in relation to the tides. As remains of grasses are found in the sod sections several feet below the level at which they can now grow, the inference is plain that portions of the marsh formerly stood higher in relation to the tides. Professor Charles A. Davis has made a careful study of the marshes about Boston by means of borings, and he has found even at a depth of twelve feet below the surface of the marsh, peat that was composed of the grasses now growing on the surface.

It must be remembered, however, that the height of the tides is dependent very much on the character of the shore line, as Professor D. W. Johnson has shown, and as this changes from time to time independently of changes of land level, regions not previously flooded may suddenly be drowned by high tides. This fictitious appearance of coastal subsidence, however, need not blind our eyes to the many incontestable evidences of true subsidence which cannot be so explained.

As an example of the possibility of errone214 
ous interpretation of marsh deposits, the case of a similar seashore region, that of the North River valley at Scituate is instructive. Here for many years prior to 1898 the mouth of the river bed had been so silted up that the tides were practically excluded - and the level of the marsh, which supported a fresh water vegetation, came to be, as subsidence continued, several feet below the level of high tide on the outer beach. In the great November storm of 1898 the sea broke through the barrier beach some distance from the mouth of the river, and since then the tide has ebbed and flowed freely in the valley, drowning out the fresh water vegetation and killing grass, bushes and trees. The marsh of a salt water formation is gradually building up to the high tide level. Suppose, then, that in the course of centuries this new mouth should become silted up, the influx of salt water excluded as before, the marsh would again take on a fresh water character. If these changes were repeated several times a section would show alternations of fresh and salt water deposits. The unwary geologist might infer, and his inference would be extremely plausible, that there had been times of alternate elevation 


\section{SAND DUNES AND SALT MARSHES}

and subsidence of the land, whereas in reality there had been all the time a subsidence.

The evidence of the sinking of the land seems to me plain, but why is not the salt marsh drowned too, or rather why is there any salt marsh formed at all? As the land sinks and the water rises it would be easy to picture the gradual extension of the sea into the land, the waves lapping the shore, all the time reaching higher and higher, until even the old glacial hills were overflowed. This would certainly be the condition of things if the marsh did not build up as fast as the land sank, and the upbuilding can be seen in all the zones of the marsh.

Everywhere in the creeks and estuaries, shut out by the sand dunes from the impact of the waves of the sea, forests of waving eelgrass flourish and entangle the fine sediments in their meshes, and help build up this zone. When the sand brought in by the tides and storms has accumulated in shallows so that these flats are sufficiently exposed at low water, the thatch grass claims it, and entraps the finest mud among its stalks. Into this the grass from its hollow stems sends out higher and higher roots, and the whole be- 


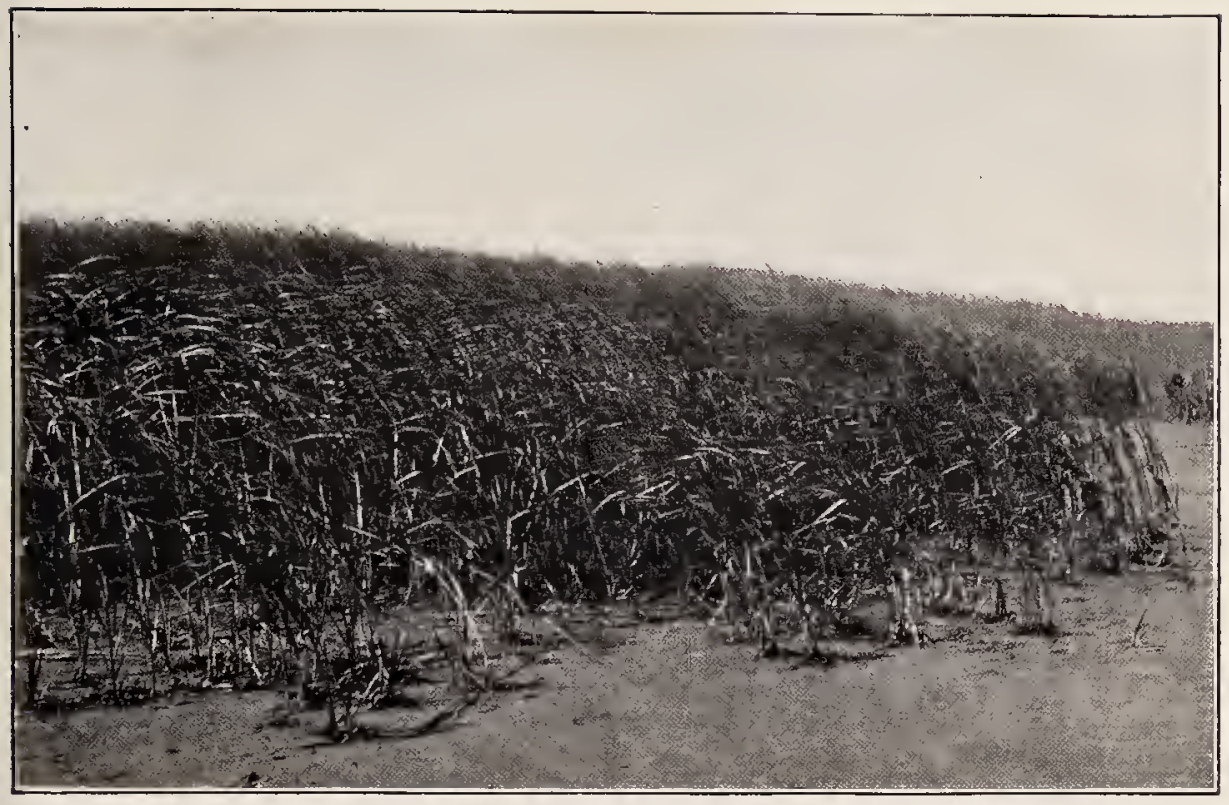

Thatch Grass bullding out on the Eddy Side of a Creek.

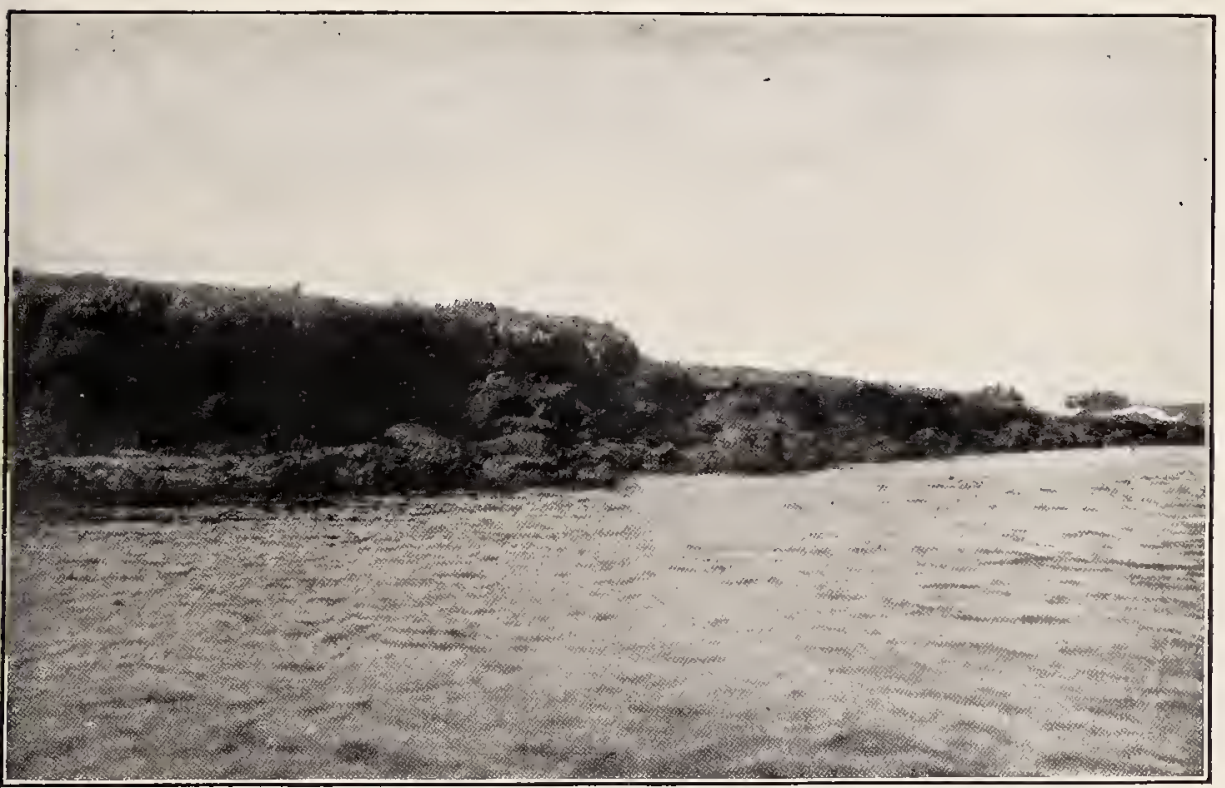

Tile Bank faliling aWay on the Channel Side of a Creek. 



\section{SALT MARSHES-PAST AND FUTURE}

comes compacted into a loose sod of mud, stems and roots, a soft, muddy, peaty mass. Thus, though the very foundation of things is sinking, the bottom does not drop out, and the depression is so gradual that the grass easily keeps pace with it.

As the tide sweeps alternately up and down the estuaries twice a day each way, it bounds back and forth from side to side with great symmetry of rhythm, eating away one bank by its swift current, while the opposite bank extends itself outward in comparatively calm water or in counter eddies, and here it is that the thatch grass flourishes. Another place where one can watch the extension of the thatch, the pioneer in this great march of the marshes, so to speak, is on the large sand flats gradually building up in regions of comparative calm outside of the full swing of the tides. On one such flat in the Castle Neck River there are now nine thatch islands from two to twenty-five feet long, besides five small single tufts of grass, and none were to be seen there twenty years ago. In another place a large thatch island a hundred yards long and half as wide has appeared and grown within the memory of one of my farmer neighbors 


\section{SAND DUNES AND SALT MARSHES}

in the last sixty year's. A shift in the currents may in a short time wash away this work of years, and may even enlarge some of the creeks, but I am inclined to think that the general tendency is toward a contraction of the tidal estuaries by the enterprising thatch.

The third zone, that of the marsh hay, which constitutes the greater part of the broad marsh, is in the same way able to keep its level in relation to the water by the gradual deposition during high tides of fine mud and sand, and by the climbing up of the grass on the shoulders of its dead ancestors. In the swirl of the tides the sand and mud are constantly carried up from the sea, and while the sand holds its place in tolerably swift water, the mud comes to rest only in regions of comparative calm. Both are dropped in periods of quiet water between tides. The fresh water detritus brought down by the rivers here is so small in amount that it plays but an insignificant part in the building up of the marshes.

In calm weather a surprising amount of sand is borne along by the rising tide, floating on the surface in the same way that a needle can 

be floated in a tumbler of water. The slightest touch of a grass blade or a cat's paw of wind sends the sand to the bottom. In winter, ice cakes, with mud and sand frozen into their lower surfaces, or bearing loads broken away from the banks, are often stranded far afield by the high winter tides, and, in melting, materially help in the building up of the marsh. A certain amount of sand is blown inland over the marshes from the dunes.

The fourth zone of vegetation, the zone of the black grass, which fringes the whole region, is visited only by the exceptionally high tides, and very, very slowly creeps up on the fresh water land, displacing the life there, be it fragile herbs or mighty forest trees. All yield before the strength of the salt sea. It has been found that one and a half per cent. of common salt in the soil is poisonous to plants that do not naturally grow on the seashore, while sea water contains two and a half per cent., and the soil of salt marshes, on which all these halophytes, or salt-loving plants, grow, may contain even more salt.

In other words, the vegetation of all the zones holds its own, and in places more than holds its own against the advancing sea. A 


\section{SAND DUNES AND SALT MARSHES}

slight increase in the rate of subsidence might reverse this, and the sea would drown the grass, and great inland bays of sea water would replace the marshes. With a cessation in subsidence, the estuaries would become more contracted, and the fresh water vegetation would very gradually creep down upon the marsh. A change to a movement of elevation and the salt marshes would in the course of time cease to exist.

Accurate maps of the marshes made from time to time, even in the brief space of the white man's occupancy,-less than three centuries, - would be of great value in showing the changes that have taken place, but such maps are lacking. In England, however, history goes farther back, and there is plenty of evidence that the marsh lands of East Anglia, the region of the Norfolk Broads, which corresponds in many ways with this Ipswich region, have become less and less invaded by the sea, notwithstanding the subsidence which is going on there as here.

When the Romans devastated the country, they sailed far up the great tidal estuaries, which are now narrow sluggish streams meandering through meadows of fresh grass, and 
attacked the ancient Britons in the highlands at Reedham and Norwich, now eighteen miles from the sea, and here they "buylded toures. on the clynes of the ocean in dyverse places." One may read in the Saxon Chronicle that in the year 1004, Sweyn with thirty ships plundered and burned Norwich. Even as late as 1327 it is stated that Norwich is " situate on the bank of a water and arm of the sea, upon which ships, boats and other vessels have immemorially come to their market."

Accumulations of silt and the growth of vegetation, narrowing these estuaries into sluggish streams, with here and there dwindling sheets of shallow water called broads, can be explained by the cutting off of the sea and tidal currents owing to the formation of sand-bars and later of dunes at the mouths of the rivers. The most famous of these sandbars is the one on which the fishing town of Great Yarmouth now stands. Even before the Norman Conquest the sand-bar at this point had become a sand bank frequented by fishermen. Later man coöperated with the ocean by building dykes and drains and erecting wind and steam pump-mills still more to exclude the salt water, and hasten the depo- 


\section{SAND DUNES AND SALT MARSHES}

sition of mud and sand and the building up of vegetation.

That subsidence is still going on, however, is evident from the fact that parts of the Broadlands are below the level of high tides, protected from the ocean by only a narrow strip of sand dunes. In places the sea is gradually gaining on the sand, so that the ruined church of Eccles, found by Lyell half buried in the dunes in 1839, has since been entirely destroyed by the waves, and it is feared that the sea will finally conquer and flood the sunken land.

From these same Norfolk marshes nearly three hundred years ago came to the Essex marshes in the new world many of the ancestors of the present inhabitants. It is pleasant to fancy that the love possessed by some of us for salt marshes may be inherited from our English forebears, who long years ago hunted and fished in the marshes and tidal estuaries of old Norfolk.

One can see in the mind's eye the recession of the glaciers, the bare gravelly hills and the numerous streams coursing over the sandy boulder-strewn plains high above the sea, which was then many miles to the eastward; 
the coming of plant and animal life, including that of man himself; the cutting down of the streams, the slow gain of the sea on the land as the latter sank, and its extension in the form of estuaries into the river valleys; the piling up of the barrier sand reefs and later of the dunes, and the extension and building up of the salt marshes, keeping pace with this depression, and their gradual march to the westward as the sea gained on the land.

Shaler said of the salt marshes: "The remote and picturesque coral reefs have long proved fascinating subjects to the geological student, while these near-at-home structures, which are in their way almost as interesting as the work of the polyps, have never been adequately studied."

Those who decry the study of science as dry, and advocate the reading of fairy stories and romances only for the cultivation of the imagination, are evidently totally unaware of the pleasures and possibilities of geology.

The question is often asked whether these marsh drumlins, now covered only with grass sod, were ever forested, and we are fortunate in possessing an early description of this 


\section{SAND DUNES AND SALT MARSHES}

region by Captain John Smith, who landed at Agawam, the Indian name for Ipswich, in the year 1614. He says: "This place might content a right curious judgment; but there are many sands at the entrance of the Harbour, and the worst is, it is imbayed too farre from the deepe sea.' Here are many rising hills, and on their tops and descents are many corne fields, and delightfull groves. On the East is an Isle of two or three leagues in length; the one half plain Marish ground, fit for pasture, or salt ponds, with many faire high groves of mulberry trees and gardens. There is also Okes, Pines, Walnuts and other wood to make this place an excellant habitation, being a good and safe harbour." The Indians were in the habit of clearing the ground by burning, and to this is due the openings for their corn-fields and gardens.

It was indeed a favored region, a happy hunting ground, and the Indians lived here in comparative peace and plenty before the white man came with his devastating diseases, his fire-water and fire-arms, and his corrupting morals. On the drumlins and in the dunes are many evidences of the departed race,ancient shell heaps of clams and oysters, - for 

oysters formerly throve here, and, intermingled with them, bones of the great auk, of ducks and waders and turkeys, of deer and bears and seals. Arrow-heads, sinkers, stone axes and skin scrapers, and bits of rude pottery are still to be found in the shell heaps and in the fields round about.

Another record pointing to the forested condition of the drumlins is an ancient law passed in 1650 , whereby the felling of timber on Jeffrey's Neck, Castle Neck and Hog Island was prohibited, although we learn that in 1670 all fishermen were allowed to cut wood there for house building and fuel. In 1726 a deed of sale was executed for " wood that now is, or that shall hereafter be standing, lying or growing on any part of Castle Neck so called beyond Wigwam Hill."

Although the larger drumlins, like Hog Island and Jeffrey's Neck, are now nearly bare, except for the willow trees planted to shelter cattle, the smaller islands are covered with trees and bushes and are spots of much interest to the botanist. Red oaks are the common trees, but white birches, poplars and hickories also occur, as well as a few swamp white oaks, canoe birches, sassafras and lindens, and on 


\section{SAND DUNES AND SALT MARSHES}

one island a few red pines and on another a grove of white and pitch pines. Dog's-tooth violets, oak-leaf gerardias, hepaticas and feverwort are also to be found on these islands. Oak Island in the Lynn marshes has been studied for years, and nearly four hundred different kinds of plants have been found there. It would seem as if the plants had gathered from all sides to avoid the rising tide of the salt marsh!

The meadows but lately reclaimed by the slow process of nature from lakes and ponds, the recently formed salt marshes and the sand dunes last thrown up by the sea, were then as now destitute of forests. One can easily discover by a simple experiment that in as short a time as ten years a sod-covered upland will return to an incipient forested condition, provided three destroyers - fire, the cutting tools of man, and the teeth of browsing cattle are excluded. Wild roses and blackberry brambles first spring up in the grass, and bayberries, hardhack and barberries soon follow. The more cover these give for the birds to nest and roost in, the more seeds are dropped there by these natural forest planters, and sumachs, thorns, rum cher- 
ries, apples, maples and red cedars soon appear.

So much for the marsh and its prominent features, and so much for its past history. How about its future? As Hog Island is a hundred and forty feet high, one can easily calculate that if subsidence continues to take place at the rate of a foot a century, and if the sand dunes continue to pile up and shut out the sea, so that the marsh may build up at the same rate, it will take fourteen thousand years before Hog Island disappears below the mantle of green marsh, which at the present time has almost surpassed the pebbly island of the Castle Neck River.' What manner of man will there be to see, and echo answers what indeed?

Fourteen million years from now, the marsh, after long and deep burial under heavy loads of sediment and possibly of glacial till and of lava floods, may perchance be lifted up and emerge to the light of day from an eroded mountain side as a sandy coal-seam.

${ }^{1}$ It is probable that if the coast continues to sink the barrier dunes will move inland, so that instead of Hog Island being overwhelmed by the marsh it will be battered by the sea in the same way that Great Boar's Head is now battered, and that it will finally succumb to the assaults. 


\section{SAND DUNES AND SALT MARSHES}

Imagination refuses even to consider the condition of the human race at this remote period!

Ye marshes that the restless sea doth lave,

Ye emblems of the constancy of time,

Th' eternal hills do sink beneath the wave

Yet ever on and upward do ye climb.

In summer's balmy days how fair to view! -

The waving thatch where water bathes its feet,

The short grass glistening with the morning dew,

The darkening fringe where marsh and upland meet.

In autumn's sparkling days the samphire glows, The shore birds wheel, the sea gulls soar and shriek, In winter Boreas spreads his icy floes, And crows and ducks their scanty rations seek.

O marshes, purge our minds from carking woe, Teach us to see and love thy visions fair, And with thy help may love and beauty grow For love and beauty may we ever care! 


\section{CHAPTER X}

\section{BIRDS OF THE SALT MARSHES}

“'Th' Eele-murthering Hearne, and greedy Cormorant, That neare the Creekes in morish Marshes haunt, The bellowing Bitterne, with the long-leg'd Crane, Presaging Winters hard, and dearth of graine. The Silver Swan that tunes her mournefull breath, To sing the dirge of her approaching death. The tatling Oldwines, and the cackling Geese, The fearefull Gull thet shunnes the murthering Peece. The strong wing'd Mallard with the nimble Teale, And ill-shape't Loone who his harsh notes doth squeale. There Widgins, Sheldrackes and Humilitees, Snites, Doppers, Sea-Larkes, in whole millions flees."

- WoOD.

" ГH' Eele-murthering Hearne," or, as Chaucer has it, "the ele's foo, the heroune," is perhaps the most characteristic, certainly the most spectacular bird of the salt marshes. There are several different kinds of these hearnes or herons. The smallest, the little green heron, prefers fresh water, yet it is common enough in the 229 


\section{SAND DUNES AND SALT MARSHES}

marshes, especially on the muddy edges of the creeks at low tide, where the hunting is good. As it stands or walks it may draw in its head until it appears to have no neck, or it may extend it as long as its body. If one has ever blown a blade of grass stretched tightly between the thumbs side by side, one will recognize the voice of this bird, which mimics exactly the music of the grass blade.

The night heron, half as large again as the green heron, is a familiar bird in these regions. Although, as its name would imply, it is largely a bird of the night, yet, when it has insatiable young in the nest clamoring for food, it must needs work by day. Indeed at all seasons it is commonly seen by day, but, when the young shift for themselves, it generally spends the hours of light in slothful ease, dozing in companies on the tops of bushes or trees. At dusk it is all alert, and flies to the beach and the marshes, squarrking as it goes. It delights most in the lowest tides, for then it can fish in the pools and meandering streams of the sand flats. As one pushes a canoe along a winding creek in the darkness and silence of the night, there is nothing more 


\section{BIRDS OF THE SALT MARSHES}

startling than the uncanny eries with which these birds suddenly pierce the gloom.

The adult night heron is a handsome bird, with its pearl-gray back and white breast and with its black erown and slender drooping plumes. It is very conspicuous as it stands like a sentry in the green marsh, but on the white sands it is far less noticeable. The most striking pictures made by these birds are to be seen some five miles away in the heronry - the source of supply for the whole region. The parent birds on the tree-tops, in a setting of graceful larch sprays against a clear blue sky, make up a scene which in beauty contrasts strangely with the hideous blackness and nakedness, as well as with the reptile-like actions of the young birds in the nests and on the branches below, and with the filth that assails the eyes and nostrils, and with the discordant cries that rend the air. Perhaps it it no more fair to judge of the family life and customs of night herons from a trip below the trees in which they are nesting, than it would be to judge of the customs of the Parisians by a journey through their sewer's. Be this as it may, the noise and the stench of a large heronry remain long in the memory. 


\section{SAND DUNES AND SALT MARSHES}

The great blue heron is indeed a splendid bird, for it stands more than four feet high, and it is full six feet from tip to tip of its extended wings. Although it formerly bred in these regions, it does not do so now as far as I can discover, yet it may be seen there throughout the summer. It is most common, however, in April and May and after the middle of July. Exceedingly picturesque it is as it stands motionless in the green marsh, or stalks sedately along the edge of a creek, or flaps majestically over the water.

Herons were one of the favorite quarries in the days of falconry, and Hamlet showed his familiarity with this fact, as well as his sanity, in stating that he knew " a hawk from a hernshaw." It has never been my fortune to see a hawk fly at a heron, but I once saw a common tern attack a great blue heron in a way that brought to mind some of the old hawking pictures. The screaming tern darted at the noble bird from above and behind, as it was winging its course high above the marsh. The heron screamed hoarsely, partly dropped its legs from their extended position behind, and, erecting the feathers on its head in anger, stretched and turned around its 


\section{BIRDS OF THE SALT MARSHES}

long neck in the endeavor to reach its tormentor.

John Shaw wrote in 1635 " that the heron or hernsaw is a large fowle that liveth about waters," and that " hath a marvellous hatred to the hawk, which hatred is duly returned. When they fight above in the air, they labour both especially for this one thing-that one may ascend and be above the other. Now, if the hawk getteth the upper place, he overthroweth and vanquisheth the heron with a marvellous earnest flight."

In the spring and early summer one of the most characteristic sounds of the marsh is the booming or pumping of the bittern, a sound that always recalls to me many pleasant memories of a camp in the fresh water marshes of the Ipswich River, where bitterns are more abundant. The curious sound, which seems to come from nowhere in particular, is in reality the love song of the bittern, and it so exactly resembles the working of an old pump that one expects to hear the grateful sound of gushing water. The unk-a-chunk is repeated from three to eight times. At a considerable distance the last syllable only is audible, and this chunk so closely resembles the driving of 


\section{SAND DUNES AND SALT MARSHES}

a stake into a bog that the bird is sometimes called by the country people the "stakedriver."'

On one occasion I was so fortunate as to have a very good view of a bittern engaged in the production of this extraordinary song. By paddling my canoe vigorously while the bird was absorbed in his performance, and by remaining motionless while he was resting, I had eluded observation and had approached within a short distance. This method is similar in plan to that employed in the murderous stalking of the capercaillie. As a preliminary, the bittern opened wide its bill, which it held straight up, and audibly gulped the air six or eight times. Then the "pumping" began, and with each pump the throat was swelled and the head ducked, as if the bird were terribly nauseated, and were endeavoring to rid its stomach of the air. It was not a graceful performance, or one that would seem to be especially attractive to a lady bittern,- - but I suppose it was.

Besides this curious song the birds have an interesting courtship display of soft fluffy white feathers which are ordinarily concealed, but which on this occasion are spread con234 



\section{BIRDS OF THE SALT MARSHES}

spicuously on each side of the breast while the gallant cock-bird struts before the hen.

Another interesting trait possessed by the bittern is its power of concealment. This is due partly to the streaked brown and pale buff plumage which matches admirably the dead tufts of grass, but chiefly to the motionless and un-bird-like posture, with upward pointing bill, assumed by the bird. It is sometimes almost impossible to point out a bird in this position that one has been fortunate enough to see, to another who has not seen it, so perfect is the protection afforded by the colors and the posture. I once started a bittern from the black-grass region of the marsh on a June day, and soon after realized that four objects that I had supposed were the stakes of a dilapidated gunner's blind were, in reality, the outstretched necks of four young bitterns. When closely approached they abandoned this method of deception, snapped their bills loudly in anger, erected the feathers of their necks, spread their feeble pin-feathered wings and, emitting faint hissing snarls, sprang defiantly at me. Their deserted nest was near at hand, a thin, flat platform of dry grasses. The assumption of 


\section{SAND DUNES AND SALT MARSHES}

this posture-concealing habit early in life shows its antiquity and long inheritance.

Although I have described the beautiful evolutions of herring gulls as seen from the dunes, they must again be mentioned here, for the marsh in the autumn is a favorite resort for these birds. Then it is that one sees an acre or more of brown marsh become white like snow with these splendid gulls. Suddenly they rise, the snow vanishes as they turn in shadow, again to flash out in a brilliant white cloud high in the air. As they circle about, first one way then another, all calling and talking together, they rise higher and higher, when with a common impulse they descend with great rapidity, circling sharply and tipping their wings from side to side, and the patch of snow reappears in the brown marsh.

At all seasons the herring gulls are fond of feeding in the creeks and estuaries at low tide, and one can often float in a canoe within close range of these wary birds. They are adepts at picking from the surface of the water any edible flotsam and jetsam, and they often do this without wetting a feather, save only the tip of the tail, which they spread 236 


\section{BIRDS OF THE SALT MARSHES}

and curve downwards to check their course. Occasionally, however, they throw themselves at the water in order to obtain food below the surface, and, on rare occasions, actually disappear for a moment, bobbing up later to swallow their prey.

Although herring gulls often spend the night on the beach, I have sometimes seen them collect on the marsh in the latter part of the evening, as if they were preparing to sleep there. One June day, between five and six o'clock in the afternoon, I counted over nine hundred of these birds slowly winging their way, singly and in small bands to a narrow island of green marsh, where they settled in closely crowded ranks. They were still coming in undiminished numbers when I stopped counting.

A long list could be made of the ducks that have been seen in the salt marshes, but alas, in these degenerate days, most of those on the list are of but rare or accidental occurrence. The early days are long passed when, in the words of William Wood, writing in 1634, "The Duckes of the countrey be very large ones and in great abundance, so is there of Teale likewise; the price of a Ducke is six 


\section{SAND DUNES AND SALT MARSHES}

pence, of a Teale three pence. If I should tell you how some have killed a hundred Geese in a weeke, 50. Duckes at a shot, 40. Teales at another, it may be counted impossible, though nothing more certaine.' The red-breasted merganser or sheldrake is still common enough in winter, and I have already described at some length this interesting bird. The whistler or golden-eye and the black duck are the only others sufficiently common to be included here. The whistler comes from the north early in October and remains with us until the last of April. The drake is a handsome bird, with its iridescent green head, a round white spot below its golden eye and its snowy breast and flanks. The duck is considerably smaller and has a dull brown head. They are shy birds and are always on the lookout for danger, and like the "fearefull Gull " are quick to " shunne the murthering Peece." As they fly by or overhead they make loud whistling music with their wings, and it is from this that they get their common name.

Their courtship is still more spectacular than that of the sheldrake and would take long to tell. Suffice it to say that the drake 238 


\section{BIRDS OF THE SALT MARSHES}

bobs his head back so that it rests on the rump,-a most singular and undignified position for a suitor, - that he displays his orangered legs with a spurt of water, and that he emits an extraordinary double note which is loud and rasping. In fact, he is perfectly irresistible, and the ladies all succumb, and each drake finds a duck. ${ }^{1}$

At sunset all the whistlers leave the marshes, where they have been feeding during the day, and fly out to sea to spend the night. It would be manifestly unsafe for ducks to sleep on the surface of the narrow creeks, for they would either be carried by the wind or tide against the banks or stranded on the flats, whereas on the surface of the ocean they can rest undisturbed. In the daytime I have noticed that sleeping ducks, with their bills buried in the feathers of the back, head up into the wind, and that they paddle gently so as to keep in the same place. Sometimes, with one leg tucked under a wing, the bird paddles with the other, so that it revolves in a circle.

The black duck has a different outlook on

1 For a full account of the courtship action of this bird and of the eider see " A Labrador Spring," pp. 84-95. 


\section{SAND DUNES AND SALT MARSHES}

life, for he prefers to feed by night, and when the whistler goes to sleep on the sea, he arises from his daytime slumbers in the same region and repairs to the marshes. These two ducks are the Box and Cox of the marshes. I have seen great flocks of black ducks floating in a long line off the beach in the bright sunlight, most of them fast asleep. They are alert birds, however, and cannot be caught napping, for there are always some on the watch, and even the sleepiest awake from time to time, stretch their wings and yawn, as they look about before settling down for another nap. Occasionally, and especially in stormy weather, one may be fortunate enough to find a great black mass of these birds sleeping on the beach. They present a curious sight, and loud is the roar of their wings as they rise into the air. Unlike the sheldrake, the black duck does not need a run to launch his aeroplane into the air, but has strength of wing enough to rise straight up even in a dead calm. Unlike the sheldrake, also, the black duck is present in the summer as well as the winter, for it breeds in near-by swamps, and visits the salt marshes for food. There are reasons for believing that our summer black duck is a 240 


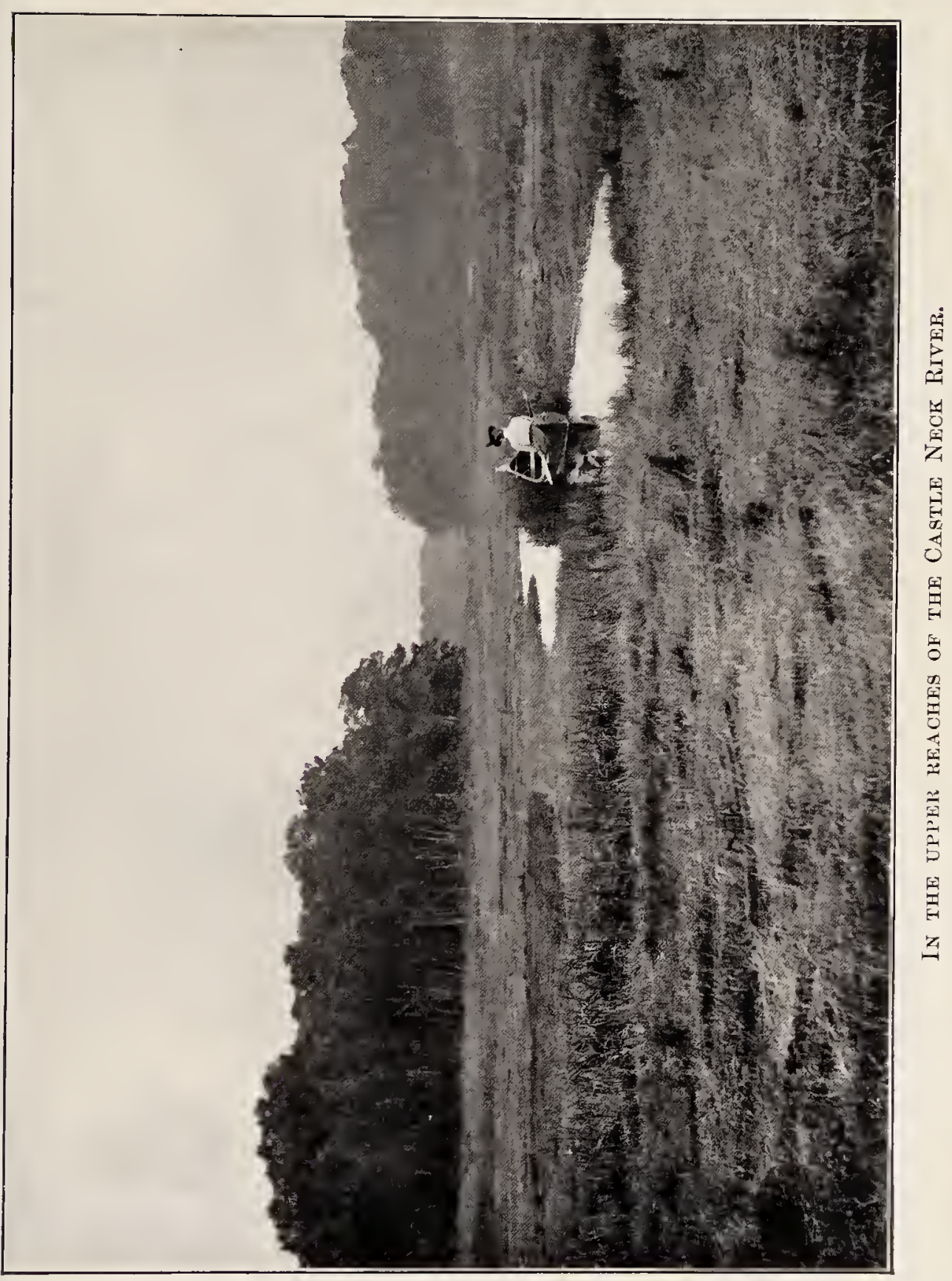





\section{BIRDS OF THE SALT MARSHES}

different race from the winter one, which comes from the north and is a larger bird, with a thickly spotted throat, yellow bill and bright red legs.

Rails are familiar birds in certain salt marsh regions. Not so at Ipswich, for only during the migrations are they found in these marshes, and then only at rare intervals, for they seem to prefer fresh-water swamps. I have several times found sora rails in the fall there; once I heard what I believed to be a black rail; and once I was treated to a very near view of the rare clapper rail, as he ran crouching along a mud flat and disappeared into the thatch. I quickly landed from my canoe and ran into the grass, when he arose from under my very feet with feeble wings and dangling legs, and flew off a few yards into the marsh. His large size, long curved bill and gray color made his identification certain. The king rail is uncommon but less rare here than the clapper rail, which it resembles closely except that it is of a rich brown color.

Although many shore birds are nearly as much at home on the marsh as on the beach, most of those that are found on the marsh are 


\section{SAND DUNES AND SALT MARSHES}

distinct from the beach-loving birds. The smallest sandpiper of all, the mud-peep or least sandpiper, has the manners and customs of its cousin of the beaches already described. It is a gentle, confiding bird and when it is intently feeding one can almost catch it under one's hat. From the sand-peep it is distinguished by its slightly smaller size, by its browner back, by its slightly decurved bill and by the greenish-yellow legs. A sand-peep in a flock of these birds of the marsh looks decidedly sandy-colored and out of place.

A larger edition of the least sandpiper, as Ralph Hoffmann has well called it, is the pectoral sandpiper or grass bird, a bird I have never seen outside of salt marshes. Unlike most of the members of the sandpiper family, the male grass bird is larger than the female. It is a bird that at times visits the marshes in numerous flocks, pouring down in great flights from the north in the fall, but in the spring it is not to be seen here, for it goes to its breeding grounds by an inland route. Its note is a rolling whistle like that of the peep, but it also emits a characteristic grating kriek.

A familiar bird of the marshes, and one that 242 


\section{BIRDS OF THE SALT MARSHES}

visits also the upper regions of the beaches, is the spotted sandpiper or teeter-peep, so named because the adults are spotted and because they all, young and old, have a nervous trick of teetering the body, sending the tail up and down as if it were on springs, and jerking the head and neck in and out. When this is accompanied by short walks back and forth, and by frequent turnings of the body, the effect is almost ludicrous. Their flight with vigorous down-curved wings and alternate scaling, is as characteristic as their teetering and their loud double whistle. In the spring they often repeat their whistle rapidly while they are flying about on quivering wings - a nuptial song and dance, no doubt. They are interesting birds and would doubtless increase if the boy with the gun would leave them alone, for they breed back of beaches and on the islands along the coast.

A near relative of the spotted sandpiper, one that resembles it in many ways, is the solitary sandpiper, frequenter of mud holes in the marsh as far removed as possible from salt water. It teeters, but in a much less exuberant manner than its spotted cousin, and, when it flies, its beautiful tail with white 


\section{SAND DUNES AND SALT MARSHES}

feathers veined with black and its pointed black wings make it easy of recognition. Both spring and fall, on its journeys to and from its breeding place in the north, the solitary sandpiper is to be found in the marsh in small numbers, for it generally lives up to its name and is solitary, although occasionally two or three are seen together. Only within a few years have its eggs been found, and, like the green sandpiper of England, it lays them in the deserted nest of some other bird in a low tree or bush.

The dowitcher resembles the snipe, but it lacks the robust, almost corpulent form of that bird, for it is decidedly more slender. While the snipe bears the name of English, the dowitcher is for some reason named German, for "dowitcher" is believed to be a corruption of deutsche. Owing to its red breast it is commonly called "red-breasted snipe " or "robin snipe," while from the color of its back it is also known as " brownback." The local names for our shore birds are legion. Gurdon Trumbull, in his " Names and Portraits of Birds which interest Gunners," gives eleven other names besides those already mentioned. He has also collected as 244 


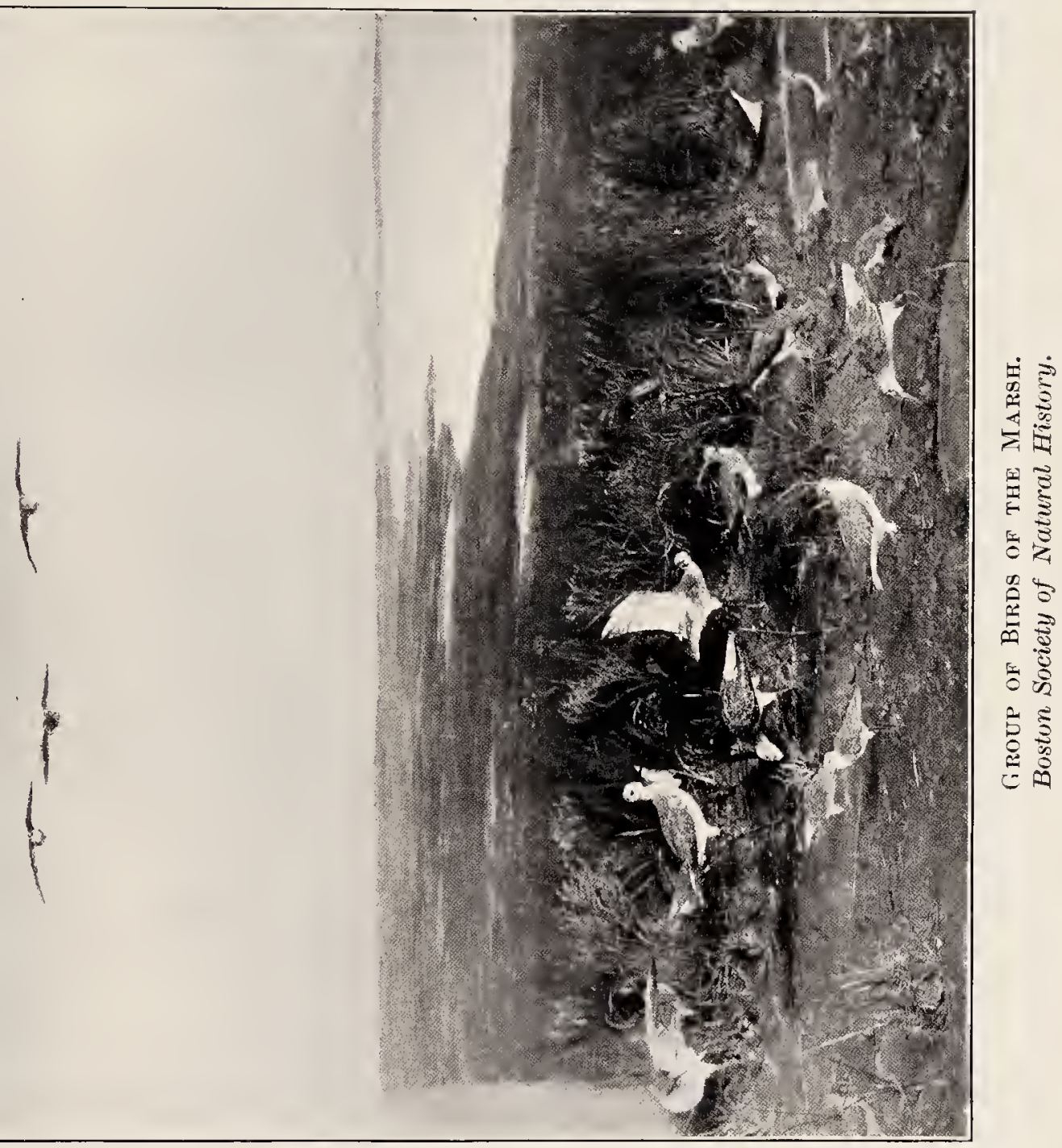





\section{BIRDS OF THE SALT MARSHES}

many as twenty-seven names for the blackbellied plover!

The dowitcher is a confiding bird, and is only too anxious to fly in among the gunner's decoys, so that it has dwindled ominously in numbers of late years. Fortunately most of the birds go south in July and early August, and as the opening of the shooting season is now delayed until the middle of August, there is still a chance that this charming bird may not be totally exterminated.

Another bird that has been in danger of extinction is the upland plover, which is now protected by law at all seasons. Although, as its name implies, it frequents the uplands, it occasionally alights in the black-grass region of the marsh, and, as it extends its wings straight up over its back and then slowly folds them, it is a beautiful object. After this preliminary it stretches its neck and looks carefully about, for it is extremely cautious and shy, and takes alarm at the least sight of man. In walking, the neck and breast are thrust in and out in a dove-like manner, and the short tail is held parallel with the ground. It is a fast runner and generally manages to get some object between it and the prying man. 


\section{SAND DUNES AND SALT MARSHES}

When it stands still, it nods its head like a nervous hen.

Its call note is a delightful bubbling sound that drops down from the sky as the bird flies over. I have heard it by night as well as by day, and its sweet but mournful character, and a certain strange unbirdliness, make it very interesting. One can only hope that this bird-which, by the way, is a sandpiper and not a "plover" - will some day breed here regularly, as in the days gone by.

Perhaps the most characteristic shore birds of the salt marshes, birds that very rarely wander to the beach, are the yellow-legs, both greater and lesser, or, as they are generally called in these Ipswich regions, "winter", and "summer."

The lesser or summer yellow-leg is very rare in the spring migration, for it goes north by an inland route, but in the fall it is generally an earlier migrant than the greater, as it is rarely seen after the middle of September, while that bird is generally most common in October, and is, moreover, an abundant spring migrant. Both birds have long yellow legs, long necks and bills and white rumps; but the greater, 'le grand Chevalier à pieds 246 


\section{BIRDS OF THE SALT MARSHES}

jaunes of the Acadians, is a third larger than the lesser, and is indeed a fine bird. Both birds have long pointed wings, and they alternately scale and fly with down-curved strokes; both lift their wings high over their backs before folding them on alighting, and both nervously teeter. They peck at their food with sudden thrusts, more in the manner of a plover than a sandpiper, and both have call notes, which, although very similar in the two species, are yet easily distinguished. The alarm notes are a series of loud wheus, deep and in volleys of six or eight in the case of the " winter," but in less number and higher pitched in the case of the "summer."

Not infrequently in the spring the marshes are filled with sweet and plaintive whistlings, the love song of the greater yellow-legs. If a man appears on the scene, the tone changes to one of loud alarm, which warns not only their own species of danger, but all other shore birds within hearing. At times they give vent to a prolonged roll, like that of a flicker, but the notes follow each other so slowly it is possible to count them, an impossibility in the case of the flicker. This roll is heard at times in the fall, and is also given, 


\section{SAND DUNES AND SALT MARSHES}

but in a more rapid fashion, by the lesser yellow-legs.

So much for the water birds of the salt marshes; they are a charming group and much more could be said of their delightful ways. There are certain land birds to be mentioned, however, that are equally at home in these regions. Chief and most characteristic of these is the sharp-tailed sparrow, a bird that bear's the same relation to salt marshes that marsh wrens do to fresh water marshes. The sharp-tails are difficult birds to find, and are generally an unknown quantity to the casual observer. They conceal their nests in the grass of the higher parts of the marshes, and under windrows of dead thatch. They move about like mice running with head low, and, when flushed, fly concealed, if possible, between the banks of a ditch. On alighting they at once disappear in the grass. However, one can become intimate with them by the exercise of due caution and patience, and they will even sit near at hand on a swaying grass blade and pour forth their song. I have heard the song given fifteen times in a minute by an ardent performer, and I suppose that his lady-love appreciated it. There is no ac- 


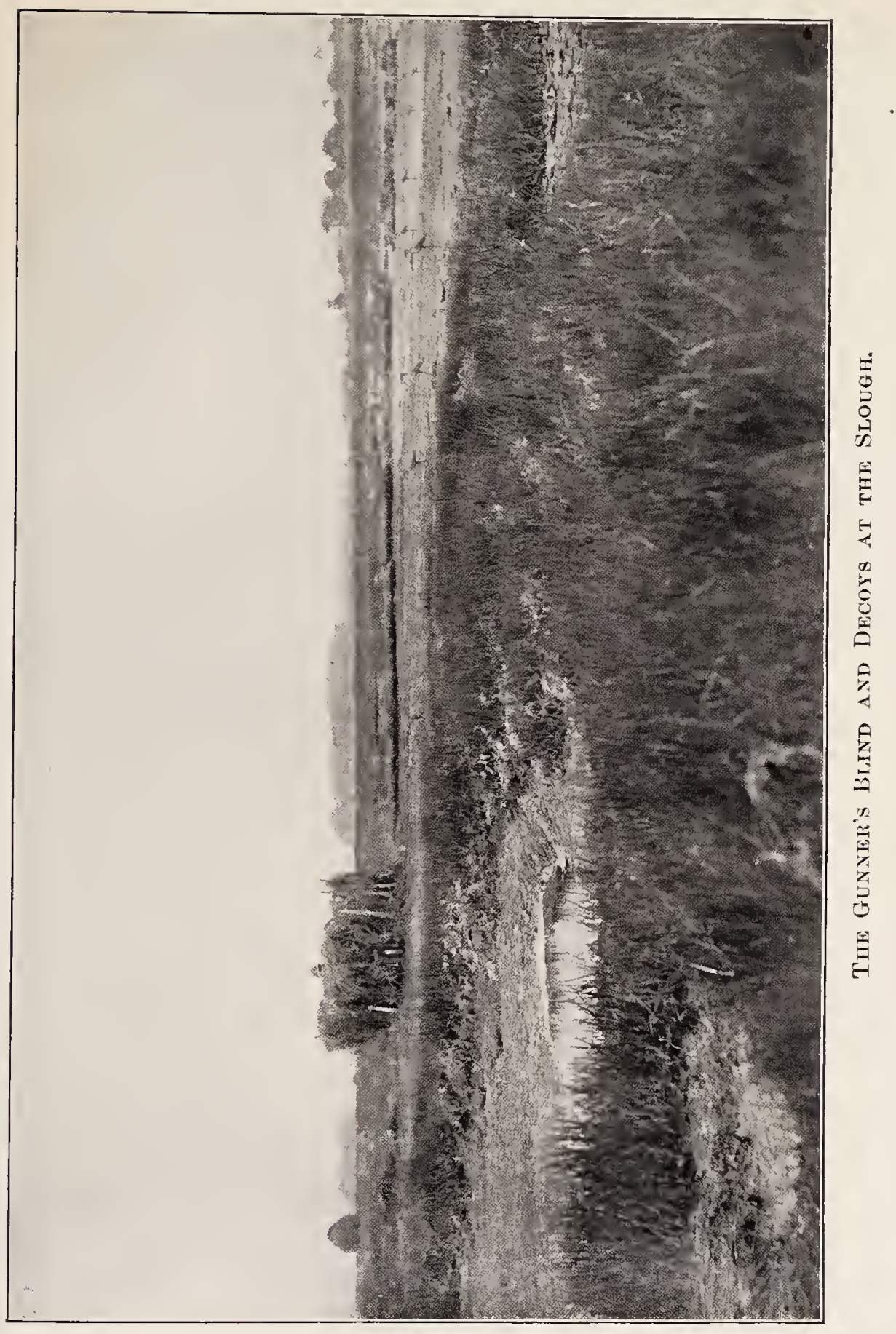





\section{BIRDS OF THE SALT MARSHES}

counting for tastes, as the song of the sharptail is a peculiar melody that resembles more closely the hiss of a hot iron in water, or the sinking of the foot into the oozy marsh than it does a song. Near at hand one can hear two short notes that follow immediately after the song. Occasionally the bird is so carried away by the rapture of his passion and music that he mounts in the air with quivering wings to the height of thirty or forty feet and pours forth his soul in rapid repetitions of the song as he drops to earth again. He is frequently unable to fly high enough to unwind his complete repertoire in the descent, for he often continues to sing after he has alighted in the grass.

The sharp-tail sparrows bring forth two broods of young, which wear a very different dress from their parents, and look in their yellow and buff the exact counterpart of female bobolinks, but much smaller.

Closely related to these birds of our marshes is the Acadian sharp-tail, which breeds farther north, along the northern half of the Maine coast and in New Brunswick and Nova Scotia. It passes through the Ipswich marshes late in May and early in June, and 


\section{SAND DUNES AND SALT MARSHES}

has similar habits and song, but can be distinguished by its slightly larger size and by its buffy and faintly striped breast.

The Savannah sparrow, already described in the chapter on dune birds, is a common frequenter of the marsh and one that breeds in the same situations chosen by the sharptail. Its famous cousin, the Ipswich sparrow, very rarely strays marshward, and when it does its gray, sandy-colored plumage is very noticeable.

Besides those already mentioned the list of land birds that visit the salt marshes is like that of the plants, somewhat limited. The marsh hawk, with its long tail and flashing white rump, frequently sails close to the surface, and rarely the short-eared owl may be seen there. The kingfisher-almost a water bird-is often there, and, in the absence of dead trees or of masts of boats, watches for its prey from the marsh bank. The crow and all the swallow tribe are very fond of the salt marshes, while the meadowlark, bobolink, red-winged blackbirds and grackles are as much at home there as in the upland meadows. The kingbird, robin, and song sparrow, the pipit, horned lark and, rarely, the snow bun- 


\section{BIRDS OF THE SALT MARSHES}

ting and Lapland longspur are also to be found there. I have seen yellow warblers drop down into the black grass from the near-by uplands, and several times in February I have found little flocks of myrtle warblers flitting from pile to pile of thatch where it extended above the ice, hunting for dormant spiders and other insects. Strange surroundings for a member of the delicate tribe of wood warblers! 


\section{CHAPTER XI}

THE HORSESHOE CRAB AND OTHER DENIZENS OF SAND AND MUD

"Neither fish, nor flesh, nor good red herring."

- Dryden.

7 HE horseshoe or king crab is an interesting beast, the sole survivor of an ancient and high-born lineage. Ancient in that it is related to the trilobites, high born because it suggests an alliance with the curious ostracoderms. The first of these, the trilobites, are found in the rocks of the Cambrian period, the most ancient of all fossilbearing rocks, and they became an important race in the lower Silurian age, only to dwindle and die out before the Palaeozoic times ended. Incidentally we may learn a lesson from their fall as well as from the fall of other groups of animals now extinct, for they all, like the ancient Romans, indulged in bizarre and extravagant developments just before their decadence. The ostracoderms form a strange 252 


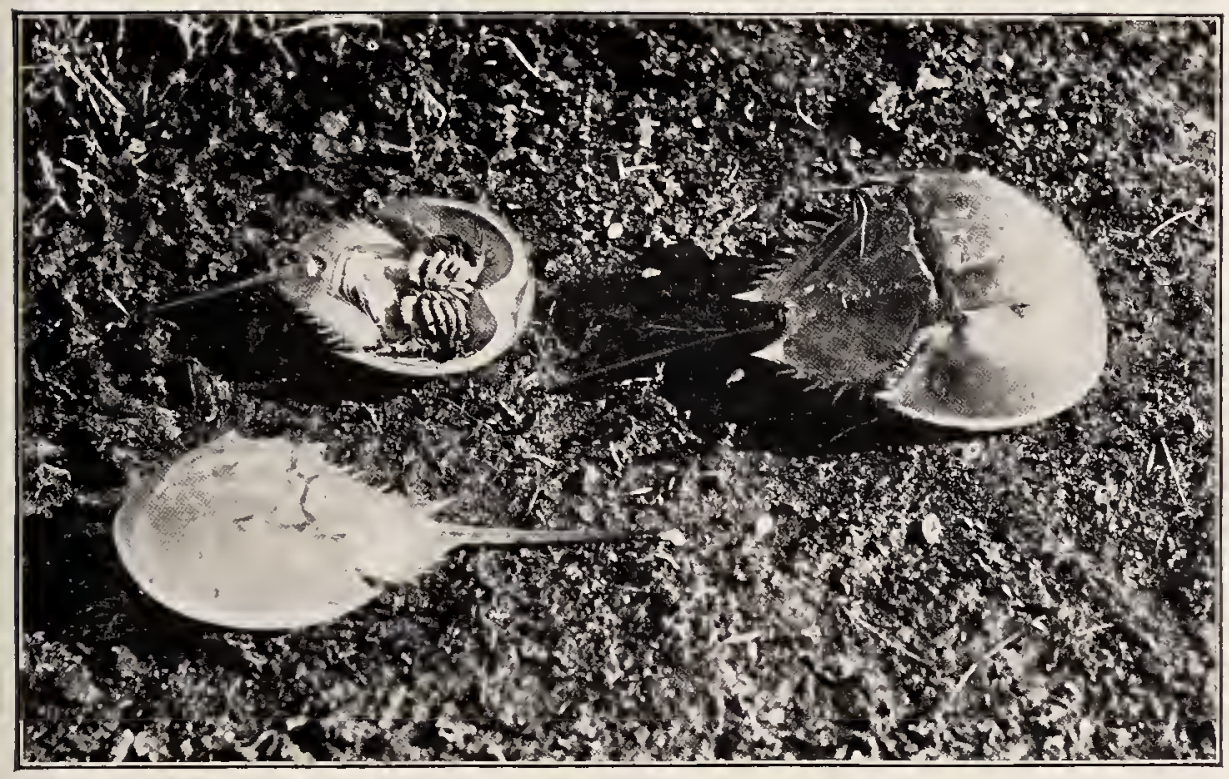

HorsesHoE CRABS.

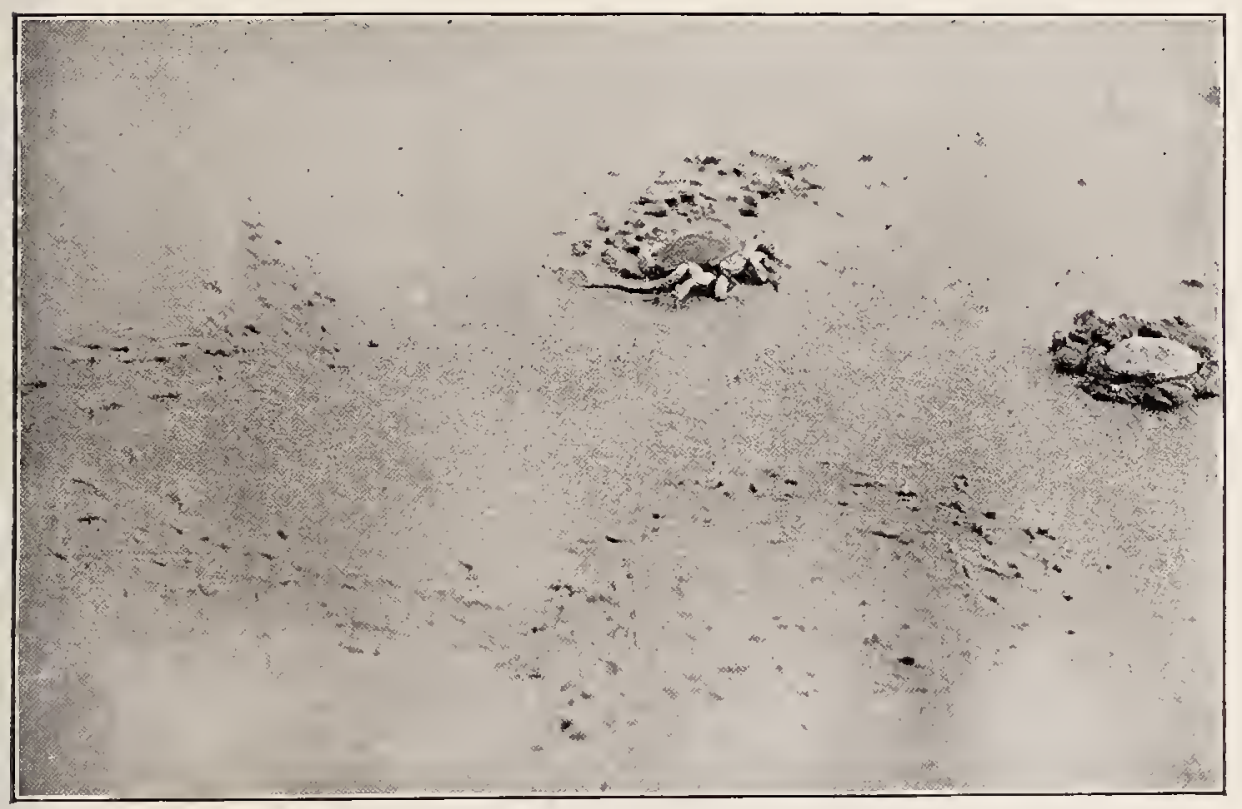

Rock Crabs ani THEIR Tracks. 



\section{THE HORSESHOE CRAB}

group of animals that flourished in the Devonian period, and, while neither fish nor crab, they combined certain features of both. To these relations of our humble horseshoe crab is given, therefore, somewhat tentatively it may be, the distinguished honor of being the progenitors of the vertebrates, of linking this highest group of animals with the lowly invertebrates, of bridging the yawning chasm between the back-boned and the back-boneless.

When one meets a horseshoe crab, therefore, it is well to treat him with respect for the sake of the trilobite and the ostracoderm with their strange histories. His days are probably numbered, for, although he is abundant in these regions, there are only two living species left in his class, one, this friend of ours of the marsh and beaches, which extends its range from Maine to Mexico, the other, a species that lives on the eastern Asiatic coast.

In the early part of the summer these strange beasts are busy depositing their eggs in all the sandy and muddy estuaries. They go about in pairs, the larger female, often dark and weather beaten, followed tenaciously by the smaller male, Later in the 


\section{SAND DUNES AND SALT MARSHES}

summer the high tides float up the delicate empty shells of the young horseshoes in hundreds on the marsh, for, like all crabs, growth is accomplished only by splitting and shedding the outside skeleton or shell. From this discarded cuticle emerges a soft-shelled and helpless individual. In this state, however, they are not often found, first, because the stage is short, and secondly, because they remain concealed until they harden sufficiently to brave the rough world. When in the usual condition they are provided with a weapon, which, for a bare-footed man at least, is most formidable. I refer to the long terminal sharp-pointed spine or tail, which they can erect at will. The horseshoe is a fair swimmer and walker, and advances straight forward, disdaining the indirect methods of true crabs, and it burrows deep in the sand by pushing its rounded front under the surface.

The beach flea, he of the large eyes, a plump, clean, shrimp-like creature about half an inch long, owes its name to its hopping powers only,-for it does not bite the living but only the dead. It is one of the most important beach scavangers, and dwells in holes from eight to ten inches deep near high-water mark. 


\section{THE HORSESHOE CRAB}

In the early morning, before the sun has dried the sand or the wind blown it away, one may see a continuous city of conical mounds made by these little workers stretching in a band along the upper beach. If one can lose all sense of proportion, a state of mind easily acquired by viewing these mounds on the ground glass of a camera, they suggest pictures of the mounds of white ants, or of the tents of an encamped army. As the waves of the flood tide wash away these erections, the water, entering the holes of the beach flea, expells air which bubbles up for several seconds at a time, leaving multiple craters like those of the moon. In the daytime this crustacean rarely ventures abroad, but at nightfall the upper beach is fairly alive with their little plump forms, hopping about, seeking what they may devour. Their night of feasting and play over, they dig their holes, in which they remain for the day.

Another beach flea, a smaller, browner creature, exists in immense numbers in the seawrack of the beach, where it serves both as a scavanger and as a food for shore birds, two very laudable purposes, but not equally appreciated by the beach flea. 


\section{SAND DUNES AND SALT MARSHES}

Another little crustacean that I will call the beach sow-bug, as it lacks a common name, is flattened from above downwards instead of from side to side, like the beach flea, and makes interesting wandering marks between tides, for instead of hopping like its nimble cousin it progresses very slowly below the surface. Similar marks are made by periwinkles and other small mollusks, while the clam-worm writes its name in the same way but more plainly.

The clam-worm is worthy of more than passing notice, for, if one looks fairly at it, it is not a disgusting beast but one of considerable beauty. Indeed it is called scientifically a sea nymph. It is often a foot or more in length, of a bluish green color and somewhat iridescent, and it is provided on each side of its flattened body with innumerable bristle-bearing legs. It is a voracious creature, and comes out of its burrow in the sand or mud to feed on other worms and on small shrimps and snails, which it captures with a pair of horny notched jaws that are kept concealed in its gullet until needed.

While on the subject of worms, I must mention the sea-mouse, an extraordinary worm 256 



\section{THE HORSESHOE CRAB}

from three to six inches long, which is occasionally cast up after a storm on the beach. Its broad back is so thickly covered with bristles that it appears to be clad in fur and remotely suggests a mouse.

The green crab, called by the scientific crazy - moenas - and by the French enragé, on account of its lively behavior and reckless audacity when brought to bay, is fonder of the milder water south of Cape Cod, where the gulf stream meanders, than it is of the shores washed by the arctic current. In the summer of 1901, however, it appeared in scanty numbers in the waters of Fox Creek, a tributary of the Ipswich River. The next year it had spread to the Castle Neck and Essex Rivers and was reported as far north as Kittery in southern Maine, while in the summer of 1903 it was abundant everywhere in the creeks, marshes and beaches. The winters, for some time mild, took on an arctic severity in 1903-4, and I was unable to find any green crabs the following summer. Milder winters have followed, and by 1910 this crab was fairly abundant again. Although green in color with yellow markings when alive, it becomes reddish when dead and cast up on the shores, 


\section{SAND DUNES AND SALT MARSHES}

but its shape easily distinguishes it from the common rock crab. Whether it has established itself firmly here or has made but a transient extension from its more southern home I do not know.

Our own common rock crab, notwithstanding its name, is an abundant frequenter of these sandy shores, both on the outside beaches and in the more sheltered estuaries. It is fully as lively as its crazy cousin, and at dead low tide one can quickly pick up a basket full in the shallow waters if he is skilled in avoiding the nipping claws-otherwise it will be a long and painful process. It has a habit of burrowing in the sand of the beach, where it remains concealed, with the exception of a narrow erevice in which may be seen its watchful eyes. The gulls often find them there, pull them out and batter them to pieces. They are good eating - almost equal to the lobster, which is comparatively rare here.

Occasionally one notices a rougher, more massive looking crab, otherwise similar to the rock crab. This is the Jonah crab, the origin of whose suggestive name is to me unknown. The sea-urchin, lover of rocky bottoms, is 258 


\section{THE HORSESHOE CRAB}

only occasionally thrown up on these sandy shores. When I meet him I wonder why I can always recall his elaborate name, Strongylocentrotus drobachiensis, with such readiness, when for the life of me I often fail to connect Mrs. Brown or Mrs. Jones with their somewhat simpler cognomens. Strongylocentrotus, however, is an old friend of mine, and years ago, when I combined the study of marine invertebrates with ornithology as a member of the Champlain Society at Mount Desert, I used often to bring up a dredge packed full of sea-urchins.

These spiny balls suggest Shakespeare, for Shakespeare calls a hedgehog an "urchin."

"Ten thousand swelling toads, as many urchins," and to this day the dwellers in Warwickshire, through which the Avon flows, call the hedgehog "urchin," and is not the sea-urchin as bristly as a land-urchin? Broken pieces of sea-urchins are not uncommon on the sides of the marsh drumlins, where they have been borne by crows and gulls and dropped from a height to break their shells, a fate that is abundantly meted out to the large sea-snails by the same birds. 


\section{SAND DUNES AND SALT MARSHES}

Another member of this group of echinoderms is the sand-dollar; which delights in sandy bottoms and is found at and below lowwater mark on the outer beach. Like the rock crab it burrows in the sand, but reveals its presence there by a slight circular elevation of the beach. In life it is covered with short spines, which give it a brown color, but to most persons its bleached and spineless cases thrown up on the upper beach are more familiar.

The more distinctly five-rayed members of this family, the starfishes, are in places abundantly represented on these shores below low water by the common starfish and by the Forbes' starfish. The latter resembles the common kind very closely but is easily distinguished from it by its light orange madreporic plate-the porous stony plate through which the sea water enters the wonderful system of canals that end in the innumerable foot tubes by which the animal drags itself along. Starfishes are ravenous creatures, and have a habit of protruding part of their stomachs and sucking in their prey. They are much disliked by oyster men, who, it is said, used formerly to cut up any starfishes they. 


\section{THE HORSESHOE CRAB}

caught and throw them overboard, not realizing that an arm with a portion of the body attached will, by pushing out new arms, become a new individual. Thus they increased rather than diminished their enemies. It is common to find individuals with one or more baby arms just appearing to take the place of those lost by accident.

If one takes the trouble to examine the great devil's aprons that are thrown up on the beach after a storm, he will find among the powerful root-like extensions from the stem, which are fastened tightly to a mussel or stone, a veritable museum of lowly marine life. Among these are not infrequently to be seen some odd-looking starfishes with distinct disk-like bodies and spider-like arms which break easily on handling. These are the socalled "brittle-stars," and if they are uninjured by their shipwreck, they will wriggle about actively and actually break off one or two of their legs in their desire to escape. It would almost seem as if they were inspired with the same object that leads lizards to shed their tails in order to distract their pursuers from the real thing.

As the tide ebbs one often finds on the sand 261 


\section{SAND DUNES AND SALT MARSHES}

-but not denizens of it, as the heading of this chapter would imply-the once free-swimming jellyfishes. They are sadly bedraggled by the waves, and entirely lack the graceful form and throbbing rhythmical movements which so excite our wonder when the animals are at home on the surface of the sea. The commonest of these is aurelia, with its transparent bluish-white disk eight or ten inches in diameter, and its group of four sacs in the middle, conspicuously straw colored or yellow in the females and pinkish in males. In the early part of the summer these jellyfishes swim strongly, and generally avoid the beach, but towards the end of the summer they become old and feeble, and are more often cast ashore. At this time the strange looking young, which are retained in the folds under the disks, are set free and attach themselves to rocks or seaweed, where they develop into little saucers piled one above the other, to be released and become veritable jellyfish the next spring.

Less frequently the large red aretic jellyfish is thrown up on the beach, looking like a great disorganized mass of coffee jelly. In its prime at sea this is a wonderful animal, 


\section{THE HORSESHOE CRAB}

as it has been known to measure seven and a half feet across the disk, and to have tentacles more than one hundred feet long. These same Medusa-like tentacles are to be avoided like the Gorgon's locks, for they are plentifully supplied with lasso-cells, which sting the naked skin as with nettles.

Among the collections of delicate and graceful seaweeds that are carefully spread out and dried by the amateur, one often finds beautiful silvery, branching specimens, which are in reality not seaweeds at all, but hydroids, humble relatives of the jellyfishes we have just been considering. On close examination one sees a multitude of little horny caps attached to these plant-like stems. They are great colonies of animals living together, and are not far removed from the corals.

A still more lowly group of animals, several of whose representatives are thrown up on the beach, is the group of sponges often considered plants, but which the great Aristotle rightly contended were animals. These northern sponges are, however, lacking in the elastic qualities which make the sponge of commerce so valuable, for, when dry, they are brittle and easily pressed to powder. The 263 


\section{SAND DUNES AND SALT MARSHES}

commonest species is the finger sponge, which is orange-red in color when the animal is alive, but which later bleaches to gray or white. Its powerful sulphurous odor when brilliantly colored is apt to discourage the attempts of amateurs to preserve it. Another common species is appropriately called the bread sponge, for it looks for all the world like a piece of soggy bread. It is generally about the size of a small muffin, but I once found one as large as a ten-cent loaf.

A whole book could be written on the group of mollusks, or indeed on any of the groups of marine animals, but the true shell-fish are more abundantly represented in number of species than any other group. A few of these only can be considered. Like the horseshoe crab, the great sea-snail, scientifically known as Polynices, - the son of Oedipus the tyrant, - pushes the sand along in a little mound as it advances below the surface. When it is moving on the surface, one is astonished at the large size of the animal, with its immense foot, as the portion on which it creeps is called, and wonders how it can possibly retire into its shell. If one picks it up, it at once pours out water as from a watering pot, rap- 


\section{THE HORSESHOE CRAB}

idly shrinks in bulk, and not only draws its entire body into the shell, but shuts the door after itself with a tightly fitting, horny operculum. This sea-snail, like all dwellers in or near the sea, has a tremendous appetite, and devours all sorts of game, dead and alive. It is particularly fond of other members of the same group of mollusks, and, in order to suck out their insides, it has a habit of boring a little hole through their shells as smoothly as if it had used a drill. This it does by means of a fleshy ribbon armed with rows of teeth that it conceals in its mouth, an instrument known as the lingual ribbon. Everywhere along the beaches curious sand collars, as the children call them, are to be found. These are shaped like the small boy's broad collar and are open in front. When wet they are flexible, and, if held up to the light, they are seen to be studded with small, round transparent bodies. These are the eggs of the seasnail, and she makes for them these curious egg cases of sand granules firmly glued together.

Lining the beach in windrows are generally to be found the pretty shells of another mollusk, which I shall call the wicker-basket shell, 


\section{SAND DUNES AND SALT MARSHES}

for that is the translation of its Latin name. Nearly all these shells are bored, and there is reason to believe that they are the victims of their own brothers and sisters, for like the son of Oedipus, the tyrant snail, they are provided with lingual ribbons, fierce appetites and loose morals.

It is a relief to turn to a vegetarian mollusk, and one which has a common English name. I refer to the periwinkle, - the same that Leech's delectable Tom Noddy enjoyed eating with a pin on the top of a London bus. Indeed, the great ugly, dingy gray European periwinkle now swarms along our coast, and is crowding out the smaller, brighter-colored and more delicate native species. It is the English sparrow among mollusks.

Another univalve which is common to both sides of the northern Atlantic is the "purple" snail, whose shell is white or yellow or brown, plain or banded. If one has ever broken this little mollusk, and used it for bait, he will remember how deeply crimson stained became his fingers. In former times red must have been called purple, as witness the purple finch, which is red, and the old Tyrian purple, which was crimson, and was indeed obtained 266 


\section{THE HORSESHOE CRAB}

from near relatives of this same " purple" snail. Another snail of wide distribution that is found on this beach is the whelk. In Fngland it is cooked and eaten.

So much for the shells with one valve, the gastropods as they are called, because they walk upon their stomachs. The shells with two valves are equally numerous on this coast, and we can begin with the edible mussel, the blue mussel that is common to both the European and the northern part of the American coast. Abroad it is an important article of diet, but in wasteful America it is as yet almost totally disregarded. It occurs in great blue-black beds in the tidal estuaries, where it is held in place by tough fibrous threads called the byssus. Although its yellow contents are scorned by most Americans, it is much appreciated by certain sea ducks, especially by the great group of scoters, who swallow the mussels shell and all, and grind them up in their powerful gizzards.

The sea mussel is a stouter, larger species with variously colored shells, and these are generally cast up on the beach after a storm, tightly embraced in the roots of large devil's aprons. Another mussel which lives partly 


\section{SAND DUNES AND SALT MARSHES}

embedded in the mud or peat of the salt marshes is the ribbed marsh-mussel.

The empty shells of the razor-fish are common objects on the shores of the estuaries. They are long and narrow and sharp on the edges, all of which characters probably account for the name. They live in burrows in the sand near low-water mark, and are able to descend with such rapidity to a depth of two or three feet that one must be a rapid digger to catch them. By approaching quietly and making a sudden thrust with the spade obliquely below them, one may sometimes cut off their retreat. The method of their descent is interesting, and easily observed in a captive razor. The foot is thrust downward into the sand in a point, and then expanded at the end into a bulb or disk, which acts as an anchor so that the animal can pull itself down. The act is rapidly repeated, and the razor soon disappears from sight.

Thrown up on the outer beach after storms one often finds the thick, heavy shells of a mollusk that is shaped like the little-necked clam or quohog, but it is larger than that bivalve as usually served on the dimner table, Its scientific name is suggestive of the north, 268 


\section{THE HORSESHOE CRAB}

for, being translated, it is called the "Icelandic Arctic." It has no common name, but it may be called the northern quohog from its resemblance to its more southern relative.

Still more common on the beach are the delicate valves with greenish-yellow and highly glazed epidermis of the ribbed shell.

But perhaps the most conspicuous dead and empty shells that are to be seen thrown up on the outer beaches are those of the sea-clam, or giant clam, as they are sometimes called. These are the kind one finds in farmhouses on the coast wonderfully decorated with pictures of lighthouses or of vessels floating on blue waves. This clam is from five to seven inches long, white within and without when dead and weather beaten, but covered on the outside when alive with a pale brown epidermis. It lives close to low-water mark and so near to the surface that it is easily dug with a short stick or the fingers. The clammer walks along with a clam fork and prods every suspicious hole or slight elevation of the sand. If the clam is there, its tough, hard shell is easily detected and soon brought to view. An expert can follow an amateur over the same 269 


\section{SAND DUNES AND SALT MARSHES}

stretch of beach and find six to his one. I remember years ago riding a bronco pony along a lonely beach on Cape Cod, and jumping off whenever I saw signs of one of these clams. As far as I know this form of clam hunting is unique. It takes but a few of these great clams to make a chowder of ample proportions and most excellent flavor.

But after all the most famous bivalve of these shores, one which in its turn has made Ipswich famous, is the clam,-sand clam or soft-shell clam. Here indeed it is a sand clam, and its shells are thin and white and clean, and its flesh clear and transparent, very different from the dirty and dwarfed clams that are to be found in black dock mud. According to John Winthrop the clams at Ipswich feed only on the white sand! Much has been written on this mollusk, and its charms have even been extolled in verse. An Ipswich poet, in reviewing the attractions of his native town, ends his list as follows:

"Its Rivers, its Hills and fair Isle by the Sea,

Not forgetting that bivalve, so delicious and free."

William Wood says of these New England clams: "Clamms or Clamps is a shel-fish not 270 


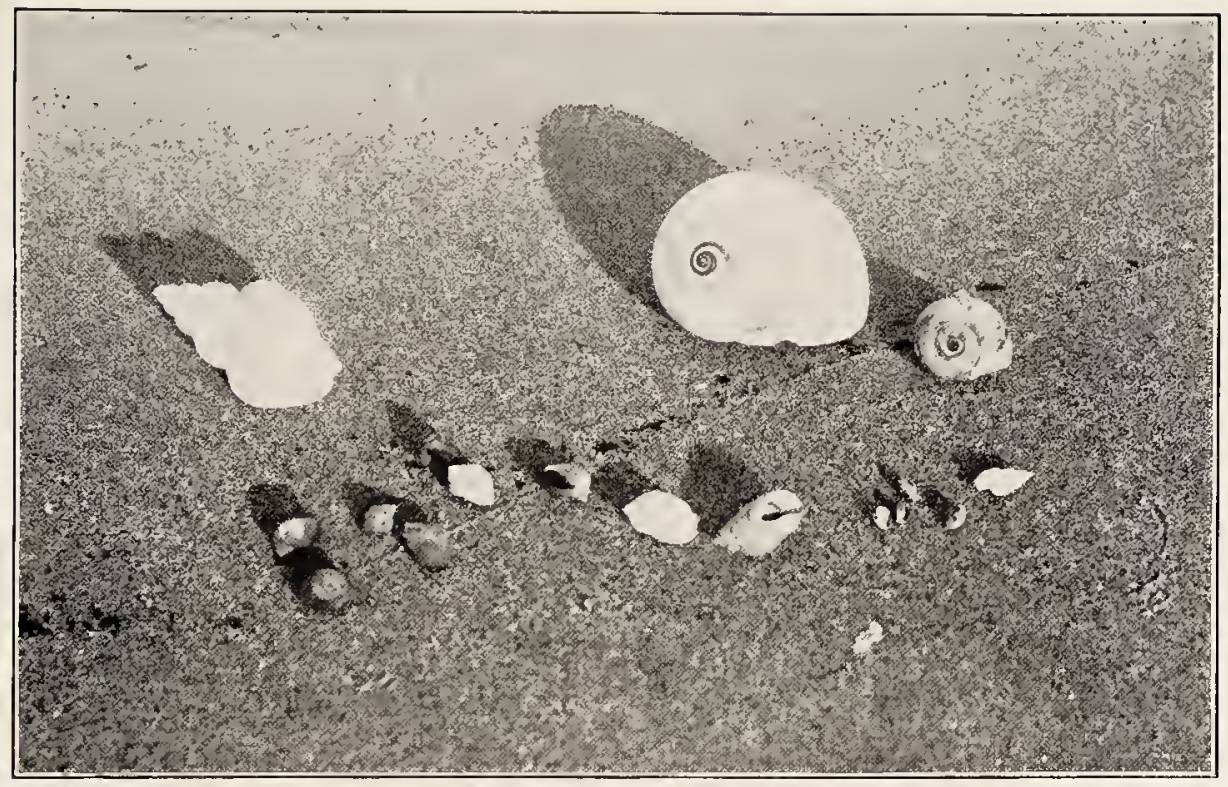

WHELK.

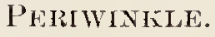

SEA-SNAII.

PURTIIE SNAIL.
WICKIR-BASIET SNAIL. BLACK-FOOTED SNAIL.

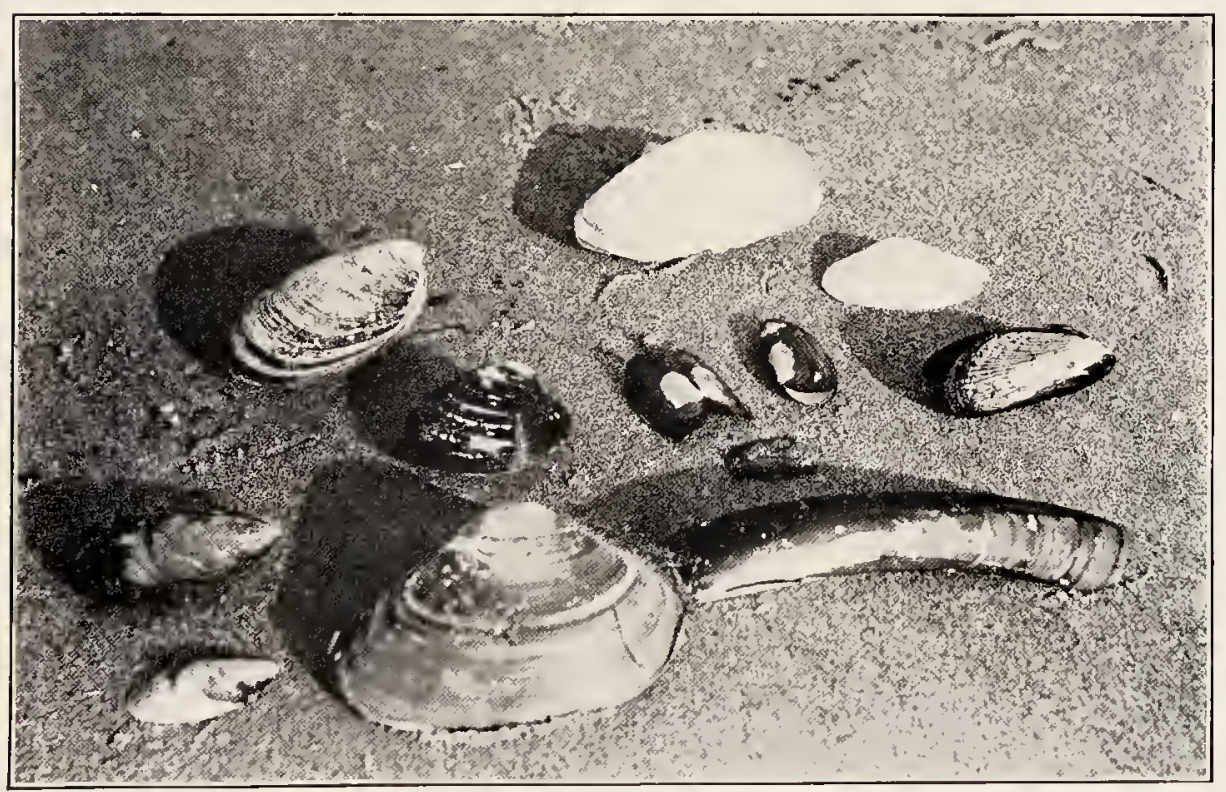

Nortinen Qtohor.

Edible Mussel.

SEA Mussei.

Comion Clam. Marsil Musgel. Sea Clay. Count Yoldi's Sheil. Razor Sheli. 



\section{THE HORSESHOE CRAB}

much unlike a cockle, it lyeth under the sand, every six or seaven of them having a round hole to take ayre and receive water at. When the tide ebs and flowes, a man running over these Clamm bankes will presently be made all wet, by their spouting of water out of those small holes: . . . In some places of the countrey there bee Clamms as big as a pennie white loafe, which are great dainties amongst the natives, and would bee in good esteeme amongst the English were it not for better fish." He also speaks of the Indian squaw,

"Which to the flats daunce many a winters Igge, To dive for Cockles, and to digge for Clamms, Whereby her lazie husbands gut shee cramms."

The digging of clams is indeed free, but at times much bitterness and some blows have resulted when the inhabitants of one town encroach on the clam flats of a neighboring town. The clam digger is a picturesque individual. He always appears to be solitary, even if there are a number working together, for each is bent and silent, intent on his own work. With a short rake with long teeth or a fork they skilfully dig up a square foot of 


\section{SAND DUNES AND SALT MARSHES}

sand, which falling down reveals the white clams. An amateur is sure to stick the fork through the clams, or to break them in raking them out, and to cut his fingers with the sharp edges. With the expert the clams seem to lead a charmed life, and escape intact into the hand and thence into the coarse, shallow clambaskets, which are then soused up and down in the salt water to free the clams from the adhering sand. Nowadays the clammers reach the flats in motor boats,-noisy and vile-smelling, - which, sad to say, have all but displaced the dories in which they formerly rowed, or sailed if the wind was fair, to and from their work. Occasionally the clammers live in weather-beaten huts near the flats, and take their spoil to the towns. One such clammer lived a solitary life on the edge of the dunes, varying his shell-fish diet with an occasional sea-fowl. But alas! he loved the bottle, and one day his dory was found containing clam-baskets and fork, but nothing was ever heard or seen of him more. A clouded brain, a misstep, the swirling tide, and the vast sea, - it is a common fate and an all too common cause. A few days after this a fortune of great proportions to such simple folk was left 


\section{THÉ HORSESHOE CRAB}

to this poor man. But it was well that his end came as it did, for he might else have died in some gilded saloon, and had an ordinary burial, instead of the soft sand of the sea floor, and the free dirge of gulls and waves and storm.

In the highest group of mollusks, those which occur in the group of "feet around the head," belong the nautilus and the cuttlefish. Of these only the small squid is found hereabouts, and it is sometimes thrown up dead or dying in great numbers on the beach. It is from eight inches to a foot long, and when caught in a pool by the receding tide it is very difficult to see, for it simulates closely the color of the sand. As it swims along it changes color almost instantly by a muscular action of the pigment cells covering the surface, so that from a dark brown creature it suddenly becomes gray, or yellow, or spotted, or nearly white. Its large eyes and suckerbearing tentacles, which stick tightly when applied to the hand, are strange things, while its mouth is provided with two dark, horny jaws, like the beak of a parrot. I have found the jaws of two dozen squids in the stomach of one shearwater I shot off the end of Cape 


\section{SAND DUNES AND SALT MARSHES}

Ann, which goes to show not only the voracity of this bird but the plentifulness of squids.

Locomotion in the squid is generally backwards and swift by the forcible ejection of water from the interior of the mantle, but the animal can also propel itself forward by turning its siphon back, as well as by the propellerlike action of the tail. When much disturbed and desirous of escaping observation, it does not hide its head in the sand, as does the fabled ostrich, but it obscures its surroundings and itself by the ejection of an inky fluid.

The last sea-dweller to which I shall refer is one that would seem to belong to the lowest order of animals, or even to the group of vegetables, but it is in reality at the top of the invertebrate tree. I refer to the seasquirt, - that one called clavata, or " like to a club or knotty branch." It is an orangecolored wrinkled affair about the size of a pullet's egg, which squirts when touched. It is set on a long stem adorned with seaweedlike hydroids and is attached to stones in deep water. A winter's stor'm is generally needed to tear these creatures from the bottom and throw them up on the beach. The warmweather beach-combers rarely find them. The 274 


\section{THE HORSESHOE CRAB}

reason this singular animal, for such it is, is placed high up on the tree of invertebrate life is because in the larval stage it has the beginnings, so to speak, of a backbone - the notochord. Having advanced thus far it seems to despair, and degenerates in the adult stage into the soft, backboneless creature with vegetable tendencies we have just seen.

I am tempted to conclude this very inadequate, but I hope suggestive, survey of the lowly life of the seashore by an account of something which does not belong to this group of marine invertebrates,-something that in very truth is neither fish, flesh nor fowl, nor good red herring, and which, although I have looked for it these many years, I have never found. But I do not despair, and some day I hope to justify my beach-wanderings in the eyes of my more practical friends, by finding a fortune in the shape of a piece of ambergris. However, I do not let the subject weigh heavily on my mind, and even if I fail in my quest my beach-wanderings have paid me well in ways not dreamed of by those same commercial-minded ones. Ambergris, or gray amber, as its name would imply, is a gray, greasy substance which is formed as the result of 


\section{SAND DUNES AND SALT MARSHES}

disease in the intestines of the sperm whale, and, when cast out by the animal, floats on the surface of the water and may be thrown ashore on any beach. There are many curious theories as to its nature, and that by old Josselyn is not the most curious. He says in his "New-Englands Rarities: " "Now you must understand this Whate feeds upon Ambergreece, as is apparent, finding it in the Whales Maw in great quantity, but altered and excrementitious: I conceive that Ambergreece is no other than a kind of Mushroom growing at the bottom of some Seas; I was once shewed (by a Mariner) a piece of $A m$ bergreece having a root to it like that of a land Mushroom, which the Whale breaking up, some scape his devouring Paunch, and is afterwards cast upon shore."

It has been known to form masses weighing over two hundred pounds, and, as it is worth many dollars an ounce for the manufacture of perfumery, one can easily estimate that a fortune awaits the lucky finder of the larger pieces. The tale is told of the finding of a piece at sea by the master of a fishing schooner, who, ignorant of the true value of the substance, had it used for greasing the 


\section{THE HORSESHOE CRAB}

masts. On his return to port the value of the small portion remaining was recognized, and he sold it for two thousand dollars, yet he was a very unhappy and dissatisfied man! Life to him became one long regret! 


\section{CHAPTER XII}

\section{BIRD GENEALOGY}

"The fairy tales of science, and the long result of time." - Tennyson.

HROM the crocodile to the crow is a far cry, yet there was a time in the remote past when ancestors of both these creatures were so much alike that it would have required a careful naturalist, had he lived then, and a thorough examination of bones and articulations, to decide whether the said ancestors were birds or reptiles. The presence of teeth do not make the reptile, nor the absence of them the bird, any more than the presence of wings make the bird, and their absence the reptile. When we study animals to-day and also consider how small are their chances for becoming good fossils, the wonder is not that there are so many missing links in the chain of organic life, but that links living and fossil should be as perfect as they are. 


\section{BIRD GENEALOGY}

To Darwin more than to any one else we owe a large debt of gratitude for the intellectual stimulus added to the study of all branches of natural history. The varying forms and colors of the land snails of the Polynesian Islands interested the old-time naturalist in the same way that a collection of china cups or of postage stamps interests the specialist in those lines to-day. But these variations of the land snails present to the modern student of evolution features of stupendous interest, even to the extent of throwing light on the formation of coral atolls, or on the subject of the previous existence of a great continent.

Archaeopteryx, the most ancient bird, as its name would imply, had teeth in its jaws, separate hip bones, vertebrae that were cupshaped on both sides, claws on its front limbs and a long bony tail,--all marks of the reptile, among which group it might still be placed by some were it not for the fact that the impression of its feathers has been preserved to us and stamps its essential bird nature.

Now if birds are descended from reptiles, one may perhaps still find some trace of this 279 


\section{SAND DUNES AND SALT MARSHES}

lowly origin in the infantile period of bird life, just as there are various ear-marks of the savage of the jungle in the infancy of the most gilded city dweller, not to mention the transient and permanent reversions often found among adults of this race. Thus the hoatzin of the Orinoco, a bird about the size of a pigeon, has claws on the wings when young and scrambles about the branches in a truly reptilian style. This mode of progression is, according to Beebe, still used by the adults, to the detriment of their wing feathers, that would be more presentable if reserved for friction with the air alone.

One need not go so far as the Orinoco, however, to find evidences of the quadrupedal reptilian mode of progression in birds, as witness the action of young herons before they learn to fly, when with wings and legs they climb about their family tree almost as gracefully, I dare say, as some of the ancient winged reptiles. The extension of the so-called thumb or bastard wing in the pigeon and other birds as they approach their perch may in the same way hark back to the time when the reptilian ancestor grasped with its fore feet its goal in the tree tops. Both young green and night 


\section{BIRD GENEALOGY}

herons elevate the bastard wing at times as they climb about the trees, but I have never seen them attempt to use it for grasping.

A study of the youthful stages in the life of any creature, therefore, often throws light on its family connections. If we go back farther still, more light is thrown, for the embryonic stages of every animal present in epitome - with many gaps, it is true - the life of its ancestors. What could be more significant of a reptilian ancestry than the claws which in the embryo of the penguin, for example, are found on each finger of the wings. In adult birds these claws, though generally lacking, still persist to a certain extent in some. Thus many ducks are provided with claws on the index and thumb of each wing, an evident survival of a part once important in the ancestry of the race. In the same way the hind limbs and the skull of birds show evidences of reptilian ancestry. The most striking feature, the teeth, present in the archaeopteryx and later fossil birds, is now entirely eliminated, although traces of teeth are said to be present in embryo parrots. Archaeopteryx possessed a very reptilian tail made up of seven vertebrae, each bearing a 


\section{SAND DUNES AND SALT MARSHES}

pair of feathers. In the modern bird these are largely compressed together into the " ploughshare" bone, with tail feathers arranged like a fan, but in the embryo there are six or seven separate vertebrae.

Scratch a bird and you will find a reptile, can be said as truly as the similar trite remark concerning civilized man and savage, with the difference that one must scratch much more deeply in the case of the bird.

The English sparrow, although fond of bathing in mud puddles, like all street gamins, would never be mistaken for a water bird, yet in its early infancy it is a capital swimmer, as I discovered in a perfectly innocent and excusable manner. Having occasion to shut an outside blind in my city house, I found that I had torn down a huge nest of street bric-à-brac that English sparrows had built between it and the wall. Two young had fallen to the ground below and were pounced on by a dog, two others - fat, misshapen things, mostly stomach and devoid of all but the black lines of incipient feathers - remained on my hands. As I could not rebuild their nest, and as I was entirely unprepared to furnish them with properly modified food, 282 


\section{BIRD GENEALOGY}

and, moreover, as a lover of native birds and a sworn enemy of these avian rats, I was bound to destroy them, I cast about for a method which would least disturb my peace of mind, for I did not think they would much care, being so infantile and inexperienced. I therefore dropped them into a basin of tepid water, expecting the inert masses to sink, or at least that their wabbly heads would fall below the surface. But presto-change! the creatures at once became endowed with life and vigor as if upon their native heath once more, and, with a combination of rapid wingstrokes and leg action and with necks outstretched, they scudded across the surface of the miniature pond. They could not have done it better if they had tried, and I do not imagine they tried at all, but that the action was reflex and instinctive, - entirely willynilly on their part.

Blood will out, the crocodile ancestry was working. To make sure that this was not an accident, with malice aforethought, I dropped a young red-winged blackbird into the pool below his nest. He, too, performed in exactly the same manner, and safely reached some reeds, up which he scrambled, and was there 


\section{SAND DUNES AND SALT MARSHES}

well taken care of by his excited parents. It is probable that many a passerine bird, nesting over the water, has been thus saved from destruction by this return to primitive methods.

Further experimentation showed me that very young birds generally moved the wings alternately, while older ones always flapped both wings together as in flight. From this one would infer that the primitive reptilian scramble was naturally an alternate method, while the simultaneous method was simply the more advanced style used in flight. And this leads me to speak of the chimney swifts, whose method of flight is, I am convinced from frequent and long observation, an alternate flapping of the wings. Let any one watch carefully these curious birds as they dart with amazing speed through the air, and I am sure that he will agree with me that the wings are used alternately with great rapidity. Steady flight by this method is, I believe, mechanically possible. One might argue, therefore, that the swifts retained the more primitive or reptilian method of moving the front limbs, and are therefore members of a very early branch on the avian tree. 


\section{BIRD GENEALOGY}

If this prone method of propulsion on the water on all fours is a primitive one, as indeed it must be, then birds that swim in an erect duck-like manner must have advanced beyond this stage and become specialized. I have several times seen young spotted sandpipers that were unable to fly, swim with ease like little ducks, although when very young and much frightened they return to the primitive reptilian scramble on all fours. All of the members of the shore-bird family, the sandpipers and plovers, swim naturally if they find themselves in water beyond their depths. The phalaropes, members of this family, disport themselves on the surface of the water as gracefully as miniature swans. It would seem to be a natural inference, therefore, that the ancestors of shore-birds were swimming birds, and that the art of swimming was inherited and not developed by this group, and that the phalarope was a case of reversion. The action of the young seal described in a previous chapter illustrates a case where the art of swimming was recently acquired by the group, and not of long inheritance.

In the classification of birds proposed by Dr. Hans Gadow and generally adopted at the 285 


\section{SAND DUNES AND SALT MARSHES}

present day, the Order Charadriiform, or plover-like birds, includes the shore-birds, gulls, auks and pigeons. The shore-birds, we have just seen, show evidence of a swimming ancestry, although, with the exception of the phalaropes, they habitually prefer the shore under their feet, even if it is wet and partly covered with water, to the deep sea. The presence of partial webs, as in the ring-neck, sand-peep and willet, point to the former existence of the swimming habit, rather than to a beginning of this habit, for these birds, like other shore-birds, do not swim except when unexpectedly forced to it.

If the partial web in the foot of the adult heron and shore-bird showed the beginning of the swimming habit in birds of land ancestry, we should find the young birds, like the young seal, very inexpert in the water. As the reverse of this is the case, our conclusion that these birds are of water ancestry must be correct.

Gulls and terns have fully webbed feet, but their habits at the present day hardly justify them in this possession. Webbed feet are of great advantage to the rapidly swimming bird and to the diving bird that depends on its feet. 


\section{BIRD GENEALOGY}

Now terns rarely rest on the water or swim, and gulls do not often swim rapidly, in fact, they rarely swim at all, but drift about, while, if either bird descends below the surface, it is as a result of the velocity of their plunge from the air, and their feet are probably not used. In truth, the web, although useful, is largely wasted on these birds, and it is evident that it is ancient and points to a swimiming ancestry. That this ancestry is less remote than in the shore-birds is perhaps shown by the fact that a wing-tipped gull, falling on the beach will take to the water and swim vigorously out to sea, while a similarly crippled shore-bird, falling into the water, will swim to the beach and endeavor to run inland to hide.

Before they are able to fly, young skimmers - of the gull tribe-are said to seek safety. by running into the water, another evidence of their water ancestry. Chapman in his "Camps and Cruises of an Ornithologist," speaking of young common terns a few days old, says: "Several were seen to enter an inflowing creek, drink repeatedly of the salt water and swim actively, in evident enjoyment of their natatorial powers, while the 


\section{SAND DUNES AND SALT MARSHES}

parents, who rarely alight on the water, watched them from the shore. Possibly here was an explanation of the value to terns of webbed toes. Functionless in the adult, they are of service to the young before the power of flight is acquired." In this supposition he is probably right, although this service to the young is not the reason for the existence of the webs, but the observation points very clearly to the swimming ancestry of the birds. We could not have stronger proof of it.

That the auks are out and out water birds there needs no defense, but one is at first sight puzzled by the presence of the pigeons in this group. The older systematists placed the pigeons with the partridges and the domestic fowl tribe, but pigeons may be seen wading in puddles in a manner that would alarm the barnyard cock. I have been told by a pigeon fancier that young pigeons are much attracted by water and fond of bathing therein, and that young birds are liablé to drown themselves in tanks or troughs if these are accessible to pigeon lofts. A fact of considerable interest in this connection is that a pigeon with perfectly. webbed feet has been evolved by only 288 


\section{BIRD GENEALOGY}

three years selected crossings. This may be looked upon as a case of reversion.

I recently placed a half-grown domestic pigeon in a wash tub of tepid water. With head and neck erect the bird swam with rapid alternate strokes of the feet to the side of the tub. The wings were arched up and waved slightly,-not stretched out and flapped in the water, as in the case of the sparrow. Its position was like that of a duck but low in the water, which was due, no doubt, to its wellfilled crop and its lack of buoyant feathers. Progress was much more rapid than on land, where the bird stumbled awkwardly along,indeed it had never before left the nest.

The sheathbill, Chionis by name, found in the Straits of Magellan, is so ancestral and generalized in its type that it suggests all the groups we have just been considering. Anatomically it is allied to the oyster catcher and gulls. It is classed among the plovers, but it is as marine in its haunts as are the auks, and in flight it resembles the gulls. Its appearance on land, gait and manner of courting are very much like those of a pigeon, and it goes by the name of "kelp pigeon."

While young terns take to the water, young 289 


\section{SAND DUNES AND SALT MARSHES}

cormorants when pursued take to the shore. This would suggest a terrestrial ancestry of these birds, and, according to Gadow, cormorants strikingly resemble the new-world vultures, and the habit of both these birds of sitting with their wings spread is suggestive. The fact that cormorants on rising into the air hop with the feet together, although their usual gait is a waddle, suggests a former arboreal life, and many cormorants still nest in trees.

The tree dwellers naturally hop from branch to branch, and it is probable that the earliest birds were arboreal. When the treedwelling bird descends to the ground it naturally hops there also, but hopping is not a satisfactory method of progression for a ground feeder; it does not permit of cautious approach, and it is decidedly jarring. A walking gait, therefore, may be understood to indicate a long custom of feeding or dwelling on the ground. Although the flicker is frequently seen on the ground, the ground habit is probably but recently acquired, for it has not learned to walk, while the robin, for example, is able to run and does so much more often than he hops. Young robins show, how- 


\section{BIRD GENEALOGY}

ever, their arboreal ancestry by hopping more than they run. Pipits, horned larks and Ipswich sparrows have so completely departed from arboreal habits, that they run easily and walk with grace. Walking appears to be acquired later than running. It is a very interesting fact that the Savannah sparrow, frequenter of meadows and marshy pastures, generally hops even when on smooth ground, although it is also a good runner, while its near relative, the Ipswich sparrow, frequenter of sandy wastes, almost never hops and is a good walker.

Herons, as far as I know, although constantly in the water, very rarely swim, but that they come of a swimming ancestry seems probable from the behavior of a young green heron not old enough to fly that I put in the water. It sat erect on the surface and swam off with a grace and ease that contrasted forcibly with its awkward movements on land. Not only was its poise graceful and swan-like, but the speed with which it swam, the practised manner in which it feathered its ungainly toes, the ease with which it threaded its way among the grass stalks, and dabbed every now and then at the water with its bill, 


\section{SAND DUNES AND SALT MARSHES}

all pointed to an inherited instinct, an instinct, however, that is largely if not entirely lost in adult life. This young heron had never practised the art of swimming before-it had probably never left the nesting tree, which was on a marsh island some distance from even the highest tides. Adult herons show their swimming ancestry by a distinct web between the middle and outer toes.

The use of the wings under water in some diving birds, and the significance of this fact, I have already discussed in another place. ${ }^{1}$

One is apt to think of evolution as a thing of the past, an accomplished fact, and to forget that at the present period of time this great law is still as existent as it has been since the world began. With change in habits, habitat or food, there comes, through natural selection, acting on slight variations and occasional mutations, a change in the structure to fit the new environment, and in time a new species is developed. As new species arose in the past, so they must be in various stages of formation at the present time. The great group of American warblers are for the

1 “ A Labrador Spring," Boston, 1910, pp. 180-205.

292 


\section{BIRD GENEALOGY}

most part slender-billed, insect-eating birds, that go south with the approach of cold weather. One of these, as we have seen, is enabled to spend the winter in the bleak dunes of Ipswich by a change from an insectiverous to a seed-eating habit. The yellow-rumped or myrtle warbler thrives through the cold winters chiefly on a diet of bayberries, while all the other members of this family seek more genial climes, where they may continue to live on insects. Not only this, but a large number of its own species go south, and winter in the Greater Antilles, Mexico and Panama, where insect food is of course abundant. The Ipswich birds eat not only bayberries, but also the seeds of grass and weeds that extend above the snow, and they glean the bark of trees like titmice for larvae.

Now birds like men are clannish; in fact, there is a remarkable similarity between animal and human nature,--which is not so surprising when one considers our origin and relationships. Among savages slight differences, due to different environment, set apart one group or race from another. Each race considers itself the people, and despises, fights and refuses to mix with the other. The Es293 


\section{SAND DUNES AND SALT MARSHES}

kimo and the Indian, although both manifestly of Eastern origin, so dislike each other that intermarriage, except under the influence of civilization, is rare. This tendency makes of course for differentiation; without this tendency the constant mixture of races would make the production of new species more difficult. While this clannishness is most marked among savages, it is also so pronounced among civilized races that each nation classes all foreigner's, especially those that speak a different tongue, as their inferiors, with whom intermarriage is not to be thought of. The more ignorant the individuals, that is to say, the more primitive or animal-like, the more intense is this clannishness, and its boundaries may be limited, not by the nation or state, but even by the village in which the individuals live. Mr. Punch's collier, who proposed " 'eaving 'alf a brick" at the stranger in town, is an instance in point.

The element of home also enters into this exclusiveness which favors the formation of races, and hence of new species. This factor is strongly shown in the human species unless the individual has become cosmopolitan by travel and education; and the inhabitants of 


\section{BIRD GENEALOGY}

what appears to an outsider to be a most desolate region regard their home as superior to any other country on the globe, and pine if taken away from it.

Now the seed-eating myrtle warbler that spends its winters in the cold and stormy north is undoubtedly as clannish as the Eskimo, and considers itself superior to the south-seeking myrtle warbler, and it would probably pine for its northern home if transplanted by force with the rest of the species to tropical regions. Its clannishness probably also impels it to choose a summer home apart from its southern relations.

At present man cannot distinguish the northern from the southern myrtle warbler, just as in the remote past it is probable that the Eskimo could not be distinguished from the Indian. In time, however, aided by this inherent clannishness and love of home, one might predict that a larger race of northern myrtle warblers would be formed with thicker, stronger bills and more muscular gizzards. Indeed, I have endeavored to investigate these three points in order to discover whether a beginning had been made in the evolution of this new species, but I have not as yet exam295 


\section{SAND DUNES AND SALT MARSHES}

ined enough material to throw any light on the subject.

One can easily see how important the element of clannishness is, for without that, interbreeding might for a long time, if not indefinitely, delay the birth of a new species. The importance of this factor in the evolution of races and species, has, I believe, never been given due weight.

As among men so among birds there are striking differences in ambition and ability to succeed. Some men, some families, some nations are progressive, - they are always reaching out for new opportunities and taking advantage of them. Others are retiring, unambitious and contented to remain where they are. One of the most markedly progressive birds is the horned lark found on this coast so abundantly in the migrations. The horned lark has spread to nearly every part of the continent and has made each part so much its home that it has adapted itself to the environment to the extent of changing its own form and plumage. There are now recognized fourteen different North American races, or sub-species, as they are called, of the horned lark. The pushing character of 296 


\section{BIRD GENEALOGY}

the bird is shown in the recent extension of the breeding range of the prairie horned lark from the central part of the continent to New England. In 1889 it was first recorded as breeding in Vermont, and the same year in central Massachusetts. In 1903 it reached the sea and bred at Ipswich, and has come there to raise its young ever since, meanwhile increasing in numbers throughout the New England states.

The song sparrow has adapted itself in twenty different forms to all parts of the continent, and is abundant almost everywhere. Incidentally it is interesting to compare a map of North America showing the various lingual races of Indians with one showing the various races of song sparrows. Both maps show one extensive race in the more uniform East - the Algonquin Indians, and the melodia sparrow,-while both show in the diversified surface of the extreme West numerous races of both man and bird.

What a contrast is the enterprise shown by the song sparrow to the lack of enterprise in the case of such a bird as the swamp sparrow, for instance! Although first cousin to the song sparrow, and although it is spread over 


\section{SAND DUNES AND SALT MARSHES}

a large territory, the swamp sparrow limits itself to the almost uniform environment of swamps, and has therefore never developed any races or sub-species.

Another bird which is showing great developmental or evolutionary possibilities is the grackle, often known as crow-blackbird. This bird, instead of shunning man, has been bright enough to appreciate the fact that it is safest from persecution when in most intimate relations with him. It has come into his towns and cities, and it does not hesitate to build its nests on his houses. In Boston, although there had been a few previous records, it was not until 1900 that this bird began to breed regularly in the Public Garden, and the numbers increased so that thirty-two nests were counted there by Mr. H. W. Wright in 1906. In 1907 they first began to build nests in the vines on my Ipswich house, and two pairs have nested there every summer since, when I permitted. In the matter of food they are not particular, or rather their appetite is a catholic one, and they can adapt themselves to circumstances. They are able to pick eggs out of a robin's nest and peas from pods in the garden, and they undoubtedly serve a useful 298 


\section{BIRD GENEALOGY}

purpose in towns and cities by diminishing the English sparrow nuisance. I have seen one hold down a struggling English sparrow with its foot while it deliberately pecked out its brains. While the English sparrows follow robins hunting worms on the lawn, and saucily snatch the worm away from their very mouths, they keep at a safe distance from the grackle, and if he so much as stops to look at them, they fly off in terror. In fact, grackles put to flight the innocent robins. I have seen a grackle partly run and partly hop, with wings extended, toward a robin that was digging worms near by, making the robin desert the spot, on which the grackle then dug.

But the most interesting development of the grackle, one that shows its great adaptability and intelligence, is a habit it has of picking up food from the water, after the manner of the herring gull. A grackle will hover close to the water, its head to the wind, and then suddenly drop, and with its bill pick up from the surface some morsel as gracefully as a gull. This they do at times without wetting their plumage; at other times the bill, feet and tail are immersed, while I once saw a grackle splash his whole body into the water 


\section{SAND DUNES AND SALT MARSHES}

and entirely immerse his head, to emerge without difficulty, carrying in his bill what appeared to be a small silvery fish. I have seen them, after sailing and hovering over the water in a high wind with the spray dashing about them, skilfully pick up food from the tops of the waves.

It is easy to picture an island community of grackles becoming more and more addicted to a maritime life, owing perhaps to the shrinking of their terrestrial food supply from change of climate or land subsidence. Would not these habits become in time as much inherited as are similar habits in the gulls? Or, to put the question in another way, were not the inherited traits of the gulls originally acquired?

The Ipswich sparrow is the only strictly dune dweller among the birds. Its summer home is on Sable Island, an island of sand dunes off Nova Scotia, and it spends its winters along the sandy portions of the Atlantic coast. It is evidently a near relation of the Savannah sparrow, who is somewhat smaller and darker, and lives in marshes and open fields from Labrador to New Jersey. As the glaciers receded, we can picture the gradual 300 


\section{BIRD GENEALOGY}

pushing north of the Savannah sparrows, and their extension to the great sandy wastes that fringed the coast for miles. As the land sank and the waters rose, restricting these regions of sand, the struggle for life among the clan that preferred the sand dunes must have been intense, and it is probable that the larger and stronger ones, as well as those that more nearly matched in color, their surroundings were the more likely to survive. Isolation finally aided in the work, and at last a distinctly new species was evolved, a bird larger than the Savannah sparrow of the mainland, and of a gray or sandy rather than a black and brown color, so that when it squatted in terror on the sand the sailing hawk was more apt to pass it by.

It seems to me that the evolution of the Ipswich sparrow is, therefore, comparatively recent, and that the age of this species may be counted by the paltry fifty thousand years or so that have elapsed since the glacial period.

Evolution is to classification what the covering of flesh is to the skeleton of a bird; remove either one or the other and we have nothing left but the dry bones.

301 



\section{INDEX}

Agawam, 224.

Acquired traits, 300

Alder (Alnus rugosa), 85.

Alder, Black, see Winterberry.

Allen, Glover M., 42.

Ambergris, 275-277.

Amphitheatres, 17, 18, 22.

Angler-fish (Lophius piscatorius), 125 .

Anticosti, 141.

Apple orchards overwhelmed by sand, 27-29.

Archaeopterix, 279, 281.

Aspen (Populus tremuloides), 85, 225.

Audubon, 157.

Auk, Great (Plautus impennis), 225.

Bald eagle (Haliæetus leucocephalus), 22,62 .

Barberry (Berberis vulgaris), 226.

Bass tree, The (Tilia), 31.

Bastard wing, 280, 281.

Bayberry (Myrica carolinensis), $60,62,80,81,116,121,226$, 293.

Beach flea (Talorchestia megalophthalma), 35, 254, 255.

Smaller (Orchestia agilis), 255.

Beach pea (Lathyrus maritimus), 75 .

Beach plum (Prunus maritima), 80.

Beach sow-bug (Chiridotea cœca), 256.

Bear (Ursus americanus), 225.

Bearberry Uva-ursi), 74.
Beebe, C. Wm., 280.

Beetle, Staghorn dama), 68.

Tiger (Cicindella hirticollis), 68.

Birch, Canoe (Betula alba var. papyrifera), 225.

Red (B. nigra), 85.

White (B. populifolia), 19, 84, 225.

Bird genealogy, 278-301.

Bird refuges, 149.

Bittern (Botaurus lentiginosus), 233-236.

Blackberry brambles (Rubus villosus), 226.

Blackbird, Red-winged (Agelaius phœniceus), 61, 88, 191, 250, 283.

Bluebird (Sialia sialis), 115.

Bobolink (Dolichonyx oryzivorus), 250

Bolles, Frank, 113.

Bonaparte, Charles Lucien, 156.

Bowditch, Nathaniel, 212.

Brewster, William, 144.

Brittle star (Ophiopholis aculeata), 261.

Building up of marsh, 209, 216220.

Burgomaster, see Gull, Glaucous.

Burnet, Canadian (Sanguisorba canadensis), 78 .

Byssus, 267.

Cape Ann, 89, 147, 273.

Capercaillie, 234.

Cartwright, Captain George, 50, 148.

Castle Hill, 22, 31, 41 .

\section{3}




\section{INDEX}

Castle Neck, 225.

Castle Neck River, 208, 210, $227,257$.

Cedar, Red (Juniperus virginiana), $85,227$.

White (Chamæcyparis thyoides), 212.

Chapman, Frank M., 287.

Chaucer, 91, 98, 229.

Cherry, Rum (Prunus serotina), 226.

Chimney swift (Chætura pelagica), 284.

Choate, Rufus, 207.

Clam, Little-neck (Venus mercenaria), 268.

Sand (Mya arenaria), 13, 14, 269-273.

Sea (Spisula solidissima), 13, 269.

Clam worm (Nereis virens), 256.

Clammers, 271-273.

Clannishness, 293-296.

Cockle-bur (Xanthium echinatum), 73.

Cod (Gadus callarias), 125.

Coffin's Beach, 27.

Coffin's farm, 27, 28.

Cogswell, Aaron, 31.

Coot, see Scoters, also Mud-hen.

Cormorant, Common (Phalacrocorax carbo), 137-139, 290.

Double-crested (P. auritus), 67, 137-139.

Cornish, Vaughan, 23.

Coues, Elliott, 47.

Courtship of Eider, 143.

of Golden-eye duck, 238, 239.

of Red-breasted merganser, $145,146$.

Crab, Green (Carcinides moenas), 257, 258.

Horseshoe (Limulus polyphemus), 252-254.
Jonah (Cancer borealis), 258.

Rock (C. irroratus), 258.

Cranberry, American (Vaccinium macrocarpon), 75-77.

Crossbill, Red (Loxia curvirostra minor), 96, 97.

White-winged ( $L$. leucoptera), 96, 97, 98 .

Crow (Corvus brachyrrhynchos), 51, 52, 59-61, 80, 88, $89-91,250,259$.

Crow pellets, 60, 61 .

Cuckoo, Black-billed Coccyzus erythrophthalmus), 88.

Curlew, Eskimo (Numenius borealis), 157.

Hudsonian (Numenius hudsonicus), 157, 158.

Darwin, Charles, 279.

Davis, Charles A., 214.

Deer, Virginia, 39-45, 225.

Devil's apron (Laminaria longicruris), 261, 267.

Dodge, Julian M., 48.

Dodge, P. B., 30.

Dogfish (Squalus acanthias), $125,126$.

Dog's-tooth violet (Erythronium americanum), 205.

Dowitcher (Macrorhamphus griseus), 244.

Droppings of fox, 52,53 .

of skunk, 58.

Drowned land, 211.

Drumlins, 29, 207, 208, 209, 210, $211,223-227$.

Duck, Black (A. rubripes tristis; northern race $A$. rubripes), 67, 204, 238, 239-241.

Golden-eye (Clangula clangula americana), 130, 238, 239 .

Long-tailed, see Old Squaw.

Dunlin (Pelidna alpina sakhalina), 156.

Dwight, Jonathan, Jr., 107, 109.

304 


\section{INDEX}

Eagle Dune, 22.

Eclipse plumage, 143, 144.

Eider (Somateria dresseri), 143, 144.

Elm (Ulmus americana), 85.

Ermine, see Weasel.

Eskimo, 293, 294.

Eskimo dog, 178.

Essex River, 27.

Evolution, 279, 292, 295, 301.

Falconry, 232, 233.

Fern, Cinnamon (Osmunda cinnamomea), 79.

Interrupted (O. Claytoniana), 79.

Royal (O. regalis), 79.

Fernald, M. L., 85.

Feverwort (Triosteum perfoliatum), 226.

Finch, Pine (Spinus pinus), 96.

Purple (Carpodacus purpureus), 103, 266.

Flicker (Colaptes auratus luteus), 63, 80, 88, 290.

Flight of gulls, 65, 127-130, 236.

Forestration, 226.

Fox (Vulpes fulvus), 46, 49-53.

Freeman, John R., 213.

Gadow, Hans, 285, 290.

Gannet (Sula bassana), 135137.

Gerardia, Oak-leaf (Gerardia virginica), 226.

Purple (G. paupercula), 74.

Seaside (G. maritima), 196.

"Geysers," 35.

Glacial period, 206-209, 301.

"Glacier," 32, 33.

Glass ground by sand, 23.

Glasswort, see Samphire.

Godwit, Hudsonian haemastica), 158.

Goldenrod, Seaside (Solidago sempervirens), 74, 197.
Grackle, Bronzed (Quiscalus quicula æneus), 88, 250, 298-300.

Grass, Arrow (Triglochin maritima), 195.

Grass balls, 35, 36 .

Grass, Beach (Ammophila arenaria), 13, 14, 17, 70, 71 .

Black (Juncus Gerardi), 196, 197, 205, 219.

Eel (Zostera marina), 190, 191, 201, 216.

Fox (Spartina patens), 193.

Poverty, see Hudsonia.

Sea spear (Puccinellia maritima), 193.

Spike (Distichlis spicata), 193.

Sweet (Hierochloë odorata), 197.

Thatch (Spartina glabra var. pilosa), 191, 192, 198, 204, 205, 216-218.

Grasshopper, Dune (Trimerotropis maritima), 68, 69.

Gravel cliffs, 29, 31.

Grebe, Holbœll's (Colymbus holbœelli), 140.

Horned (C. auritus), 140.

Grosbeak, Pine (Pinicola enucleator leucura), 96.

Gull, Bonaparte's (Larus philadelphia), 133.

Glaucous (L. hyperboreus), 132.

Great black-backed (L. marinus), 131, 132, 171, 173.

Herring (L. argentatus), 64$66,124-131,171,173,187$, $236,237$.

Iceland (L. leucopterus), 132.

Mackerel, see Tern, Common.

Ring-billed (L. delewarensis), 133.

Haddock (Melanogrammus æglifinus), 125. 


\section{INDEX}

Hake (Urophycis tenuis), 125, 126.

Halophytes, 219.

Hardhack (Spiraea tomentosa), 83, 226 .

Hawk, Marsh (Circus hudsonius), 250.

Hay canoes, 194.

Headless sailor, 22.

Headley, F. W., 127.

Hemlock (Tsuga canadensis), 85, 212.

Hepatica (Hepatica triloba), 226.

Heron, Great blue (Ardea herodias), 232, 233.

Green (Butorides virescens), 229, 230, 280, 291, 292.

Night (Nycticorax nycticorax nævius), 230, 231, 280.

Heronry, 231.

Herring (Clupea harengus), 125, $126,136$.

Hickories (Hicoria), 225.

Hoatzin, 280.

Hoffman, Ralph, 42, 91, 242.

Hog Island, 30, 207, 208, 211, $225,227$.

Hopping and walking, 290, 291. Horned lark (Otocoris alpestris), 100, 102, 250, 291, 296.

Prairie (O. alpestris praticola), 100, 296, 297.

Hudson, Henry, 182.

Hudson, William, 72.

Hudsonia (Hudsonia tomentosa), 71, 72 .

Hummingbird (Archilochus colubris), 88.

Hydroids (Sertularia pumila), 263

Ice formation at the beach, 33, 34.

Ice formation in the marshes, 202-204.

Indians, 224, 225, 271, 294, 297.
Instinct, 283, 292.

Instinct and reasoning, 65, 66 .

Ipswich River, 25, 257.

Iris, Blue (Iris versicolor), 78.

Jack Rabbit, see Prairie hare.

Jaeger, Long-tailed (Stercorarius longicaudus), 135.

Parasitic (S. parasiticus), 135.

Pomarine (S. pomarinus), 135.

Jeffrey, E. C., 212.

Jeffrey's Neck, 225.

Jellyfish, Arctic (Cyanea arctica), 262, 263.

Common (Aurelia flavidula), 262.

Johnson, D. W., 214.

Joint-weed (Polygonella articulata), 74 .

Josselyn, John, 139, 155, 276.

Kingbird (Tyrannus tyrannus), 88,250 .

Kingfisher (Ceryle alcyon), 250.

Kittiwake (Rissa tridactyla), 133.

Knot (Tringa canutus), 155, 156.

Labrador, 93, 102, 132, 139, 148, $170,178,210,211,300$.

Lady's slipper (Cypripedium hirsutum), 79,80 .

Lagoon, 13.

Lakeman, James F., 25.

Lakeman farm, 29, 30, 31 .

Lanier, Sidney, 189, 190, 199.

Lapland longspur (Calcarius lapponicus), 103, 104-106, 251.

Lavender, Sea, see Rosemary, Marsh.

Leather-leaf (Chamaedaphne calyculata), 83.

Lighthouse, Ipswich, 25.

Linden (Tilia americana), 225.

Lingual ribbon, 265, 266.

Lobster (Homarus americanus), 258. 


\section{INDEX}

Loon (Gavia immer), 140.

Red-throated (G. stellata), 140.

Lyell, Charles, 222.

Madison, President, 25.

Main, Harry, 172.

Maple, Red (Acer rubrum), 85, 227.

Maps, 30.

Marsh hay, 192-195.

Maryland yellow-throat (Geothlypis trichas), 87.

Maynard, C. J., 84, 106, 107.

Meadowlark (Sturnella magna), $115,250$.

Meadow-sweet (Spiraea latifolia), 83.

Merganser, Red-breasted (Mergus serrator), 66, 67, 140$146,238$.

Mermaids, 182, 183.

Meunier, 141.

Migration period of water birds, 123.

Migration, Swallow, 111-121.

Milk Island, 42.

Milkwort, Sea (Glaux maritima), 195.

Mink (Putorius vison lutrocephalus), 54-56.

Mother Cary's chickens, see Petrel.

Mouse, Meadow (Microtus pennsylvanicus), 54, 58, 59.

White-footed (Peromyscus leucopus noveborencis), 50, $58,59$.

Mud-hen (Fulica americana), 146.

Mushroom, Brown (Cytocybe trullisata), 75.

Muskrat (Fiber zibethicus), 56.

Mussel, Edible (Mytilus edulis), 267.

Marsh (Modiola plicatula), 268.
Sea (Modiola modiolus), 267.

Nesting instincts, Autumnal revival of, 115 .

Noah's flood, 206.

Norfolk Broads, 220-222.

North River, 215.

Notochord, 275.

Oak Island, 226.

Oak, Red (Quercus rubra), 225.

Swamp white, (Q. bicolor), 212, 225.

Oaks, William, 157.

Old squaw (Harelda hyemalis), $147,148$.

Orach (Atriplex patula var. hastata), 73.

Orchids (Pogonia ophioglossoides and Calopogon pulchellus), 78.

Oriole, Baltimore (Icterus galbula), 191.

Ostracoderms, 252.

Oven-bird (Seiurus aurocapillus), 92.

Owl, Short-eared (Asio flammeus), 98, 99, 250.

Snowy (Nyctea nyctea), 42, $99,100$.

Oyster (Ostrea virginica), 224.

Patmore, Coventry, 189.

Peep, see Sandpiper, Least and Semipalmated and Spotted.

Penguin, 281.

Periwinkle, American (Littorina rudis and L. palliata), 256, 266.

European (L. litorea), 266.

Petrel, Leach's (Oceanodroma leucorhoa), 139, 140.

Wilson's (Oceanites oceanicus), $139,140$.

Phalaropes (Phalaropus, Lobipes, etc.), 285.

Pheasant, Ring (Phasianus torquatus), $41,61,62$. 


\section{INDEX}

Phøebe (Sayornis phœbe), 115.

Pigeon, 288, 289.

Pine, Pitch (Pinus rigida), 19, $20,32,33,84,226$.

Red (P. resinosa), 226.

White (P. Strobus), 85, 212, 226.

Pipit (Anthus rubescens), 94, 95, 250, 291.

Pits in sand, 22.

Plantain, Seaside (Plantago decipiens), 195.

Play in birds, 114, 130.

Plover, Black-bellied (Squatarola squatarola), 64, 151, 152.

Golden (Charadrius dominicus), 151.

Piping (Ægialitis meloda), 62, 149, 150.

Semipalmated (Ægialitis semipalmata), 64, 150, 151, 286.

Upland (Bartramia longicauda), 245, 246.

Plum Island, 26, 80, 160.

Polluck (Pollachius virens), 126.

Poplar (Populus tremuloides and P. grandidentata), 225.

Prairie hare (Lepus campestris), 46-49.

Protective coloration, 42, 51, 69, $110,235$.

Quahog, Northern (Arctica islandica), 268, 269.

Rail, Black (Creciscus jamaicensis), 241.

Clapper (Rallus crepitans), 241.

King (R. elegans), 241.

Sora (Porzana carolina), 241.

Range-light, Ipswich, 12, 25.

Rat, Norway (Epimys norvegicus), 59.

Rate of subsidence of land, 213.
Razor fish (Ensis directus), 269. Redpoll (Acanthis linaria), 96.

Redstart (Setophaga ruticilla), 92.

Recfs, Sand, 11, 12.

Rhodora (Rhodora canadense), 83,84 .

Ribbed shell (Siliqua costata), 269.

Richardson, Sir John, 91, 104.

Ripple-marks, 15, 16, 19.

Robin (Planesticus migratorius), $87,100,191,250,290,291$, $298,299$.

Robin Reef, 160, 161.

Rosemary, Marsh (Limonium carolinianum), 196.

Roosts, Swallow, 111-121.

Rose, Wild (Rosa carolina, R. nitida), 83, 226.

Saddle-back, see Gull, Great black-backed.

Sahara, 21.

Salt marshes, 188-228.

Birds of, 229-251.

Geological history of, 206-228.

Vegetation of, 190-205.

Saltwort (Salsola Kali), 72, 73.

Sand blast, 23.

Samphire (Salicornia europaea), $195,201$.

Sand collar, 265.

Sand-dollar (Echinarachnius parma), 260.

Sand dunes, 11-37.

Land birds of, 86-110.

Origin of, 13, 14.

Rate of advance, 20, 21.

Varieties of, 16-19, 22.

Vegetation in, 70-85.

Water birds seen from, 123159.

Sand, Grains of, 23, 24

Sanderling (Calidris leucophæa), $154,155$.

Sandpiper, Baird's (Pisobis bairdi), 158. 


\section{INDEX}

Least (P. minutila), 152, 153, 242.

Pectoral (P. maculata), 242.

Semipalmated (Ereunetes pusillus), 152-154, 242, 286.

Solitary (Helodromas solitarius), $243,244$.

Spotted (Actitis macularius), $243,285$.

Stilt (Micropalama himantopus), 158.

White-rumped (Pisobia fuscicollis), 156.

Sand-star puffball (Geaster hydrometricus), 75 .

Sassafras (Sassafras variifolium), 225.

Saxon Chronicle, 221.

Scoter, American (Oedemia americana), 146, 147.

Surf (O. perspicillata), 146, 147.

White-winged ( $\mathrm{O}$. deglandi), $146,147$.

Shakespeare, 259.

Shaler, N. S., 208, 223.

Sea rocket, American (Cakile edentula), 72, 73 .

Seal, Harbor (Phoca vitulina concolor), 160-187, 225.

Seal, Harp (Phoca gronlandica), 161.

Seal, Hooded (Cystophora cristata), 161.

Seals, Bounty on, 169.

Courtship of, 179-181.

Curiosity of, 184, 185.

Evolution of, 162, 176-178.

Food of, 169, 170.

Locomotion of, 164-166.

Pelage of, 163, 164

Play in, 180, 181, 182.

Postures of, $166,167$.

Sleep of, 167, 174, 186.

Voice of, 186.

Young of, 174-179, 285.

Sea-mouse (Aphrodite aculeata), $256,257$.
Sears, John H., 213.

Sea-squirt (Boltenia clavata), $274,275$.

Sea urchin (Strongylocentrotus drobachiensis), 258, 259.

Sedge, Salt marsh (Scirpus campestris var. paludosus), 195.

Seton, Ernest Thompson, 47, 187.

Sexual selection, 143.

Shad bush (Amelanchier canadensis), 83.

Shaw, John, 233.

Shearwater, Greater (Puffinus gravis), 273.

Sheathbill (Chionis), 289.

Sheldrake, see Merganser, Redbreasted.

Shore line and tidal range, 214, 215.

Silver weed (Potentilla Anserina), 197.

Sinking of the land, 209-216.

Skate (Raja), 125.

Skimmer, Black (Rynchops nigra), 287.

Skunk (Mephitis putida), 56-58, 100.

Smith, Captain John, 224.

Snail, Black-footed (Melampus lineatus), 61.

Great sea (Polynices heros), 259, 264, 265.

Purple (Purpura lapillus), 266. Snow bunting (Plectrophenax nivalis), 52, 102-104, 250.

Snow in the dunes, 32,33 .

Sparrow, Acadian sharp-tailed (Passerherbulus nelsoni subvirgatus), 249, 250.

English (Passer domesticus), 105, 106, 282, 283, 299.

Fox (Passerella iliaca), 104.

Ipswich (Passerculus princeps), 106-110, 250, 291, 300,301 . 


\section{INDEX}

Savannah (Passerculus sandwichensis savanna), 87,88 , $115,191 ， 250,291,300$, 301.

Sharp-tailed (Passerherbulus caudacutus), 191, 248, 249.

Song (Melospiza melodia), 87, $115,250,297$.

Swamp (Melospiza georgiana), 297, 298.

Sperm whale (Physeter macrocephalus), 276.

Spider, Dune (Lycosa pikii), 69. Sponge, Bread (Halichondria panicea), 264.

Finger (Chalinopsilla oculata), 264.

Spurge, Seaside (Euphorbia polygonifolia), 73,74 .

Squid (Ommastrephes illecebrosus), 273,274 .

Staddles, 113, 194.

Starfish, Comımon (Asterias vulgaris), 260, 261.

Forbes' (A. Forbesii), 260, 261.

Steep Hill, 31.

Stratifications in sand dunes, 18 , 22.

Sub-fossils, 14.

Sumach, Poison (Rhus Vernix), 82.

Staghorn (R. typhina), 82, 226.

Sundew (Drosera rotundifolia), $78,79$.

Swallow, Bank (Riparia riparia), 88, 111-121.

Barn (Hirundo erythrogastra), 111-121.

Eave (Petrochelidon lunifrons), 111-121.

Tree (Iridoprocne bicolor), $62,80,88,111-121$.

Sweet gale (Myrica Gale), 81 , 82 .
Tern, Arctic (Sterna paradisea), 134.

Black (Hydrochelidon nigra surinamensis), 134.

Caspian (Sterna caspia), 134.

Common (S. hirundo), 133135, 171, 232, 287, 288.

Least (S. antillarum), 134.

Roseate (S. dougalli), 134.

Thatch, see Grass, Thatch.

Thayer, Abbot, 42.

Thorn (Crataegus), 226.

Thrasher, Brown (Toxostoma rufum), 93.

Toad (Bufo americanus), 50, 68.

Tracks of bald eagle, 62 .

black duck, 67 .

cormorant, 67.

crow, 59, 60 .

deer, 45 .

dog, 50 .

flicker, 63.

fox, 50 .

horned lark, 62.

herons, 64 .

herring gull, 64, 65 .

insects, 68, 69 .

Lapland longspur, 62.

merganser, 66, 67 .

mink, 55 .

mouse, meadow, 59.

mouse, white-footed, 59.

muskrat, 56.

pheasant, 61, 62 .

plover, 62, 63, 64 .

prairie hare, 47,48 .

rat, 59.

sandpipers, 63 .

skunk, 56, 58 .

snake, 68 .

snow bunting, 62 .

spider, 69.

tree swallow, 62 .

toad, 50, 68 .

weasel, 53.

Trilobites, 252. 


\section{INDEX}

Turkey, Wild (Meleagris gallopavo silvestris), 225 .

Trumbull, Gurdon, 244.

Turnstone (Arenaria interpres morinella), 158.

Tyrian purple, 266.

Upland plover (Bartramia longicauda), 245, 246.

Vischer, Hanns, 21.

Warbler, Bay-breasted (Dendroica castanea), 92.

Black and white (Mniotilta varia), 92 .

Blackburnian fusca), 92.

Black-poll (D. striata), 92.

Black-throated blue cærulescens), 92.

Black-throated green virens), 92, 93.

(Dendroica

anadian

(Wilsonia canadensis), 92.

Chestnut-sided (D. pennsylvanica), 92.

Magnolia (D. magnolia), 92.

Myrtle (D. coronata), 80, 92, 95, 96, 251, 293-296.

Nashville (Vermivora rubricapilla), 92.

Parula (Compsothlypis americana usneae), 92.

Pine (D. vigorsi), 92.

Prairie (D. discolor), 92.

Wilson's (Wilsonia pusilla), 92.
Yellow (D. aestiva), 87, 92, 251.

Yellow palm (D. palmarum hypochrysea), 92 .

Water, Pools of in dunes, 24.

Water-thrush (Seiurus noveboracensis), 92.

Wayne, Arthur T., 144.

Weasel, Little brown (Putorius cicognanii), 53, 54 .

Webbed feet, 286, 287.

Whelk (Buccinum undatum), 267.

Whistler, see Duck, Golden-eye.

Wicker-basket shell (Nassa trivittata) 265,266 .

Wigwam Hill, 30, 225.

Willet (Catoptrophorus semipalmatus), 158, 286.

Willow (Salix), 85, 225.

Winterberry (Ilex verticillata), 83.

Winthrop, John, 270.

Wood, William, 88, 139, 148, 237, 270.

Wormwood, Beach (Artemesia Stelleriana), 74.

Wrecks, 26, 27.

Wright, H. W., 298.

Xerophils, 73.

Yellow-legs, Greater (Totanus melanoleucus), 246-248.

Lesser (T. flavipes), 246, 247.

Zones of marsh vegetation, 190$197,216,218,219$. 


$$
171-R B
$$







\section{DATE DUE \\ DATE DE RETOUR}

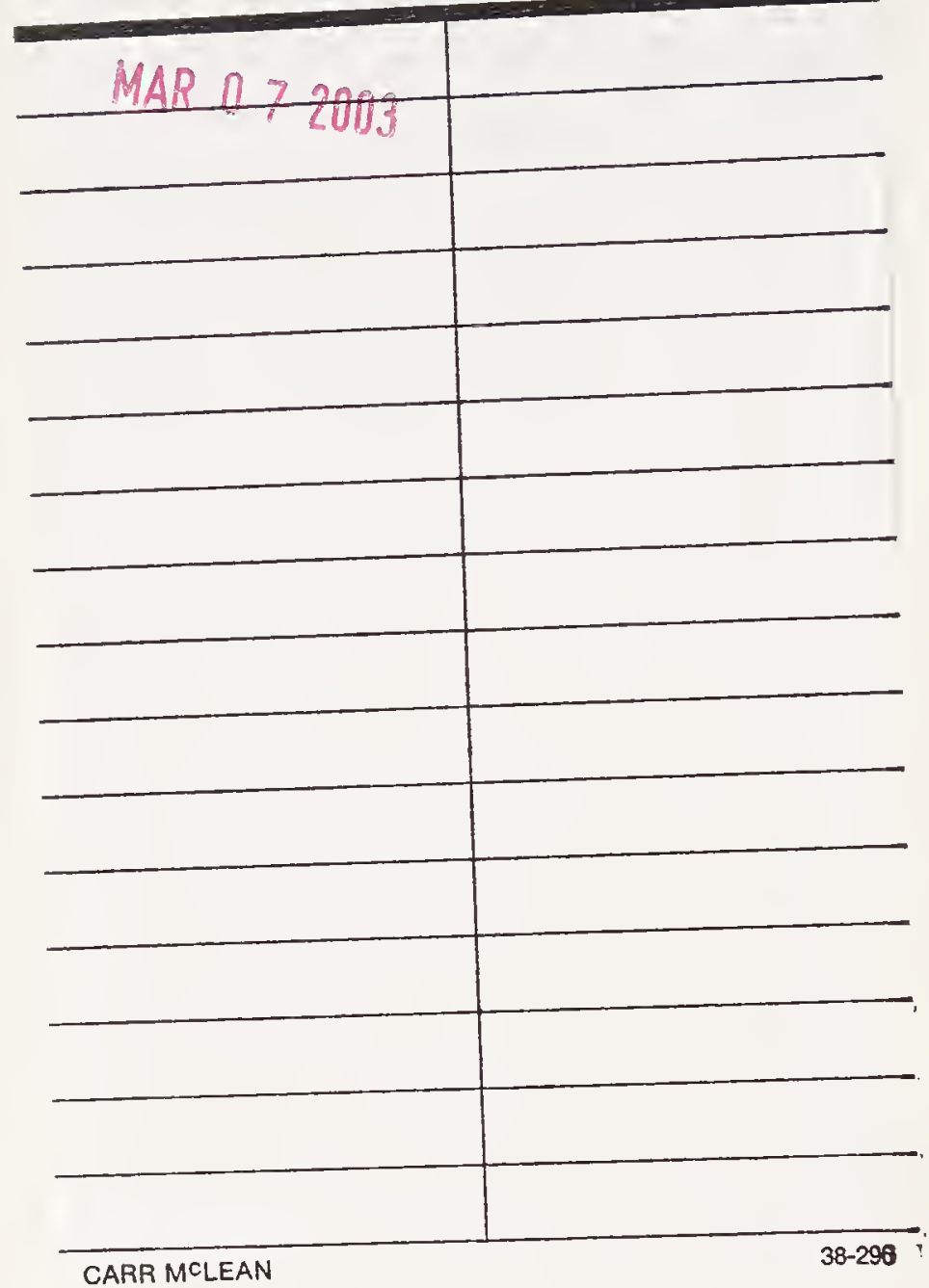



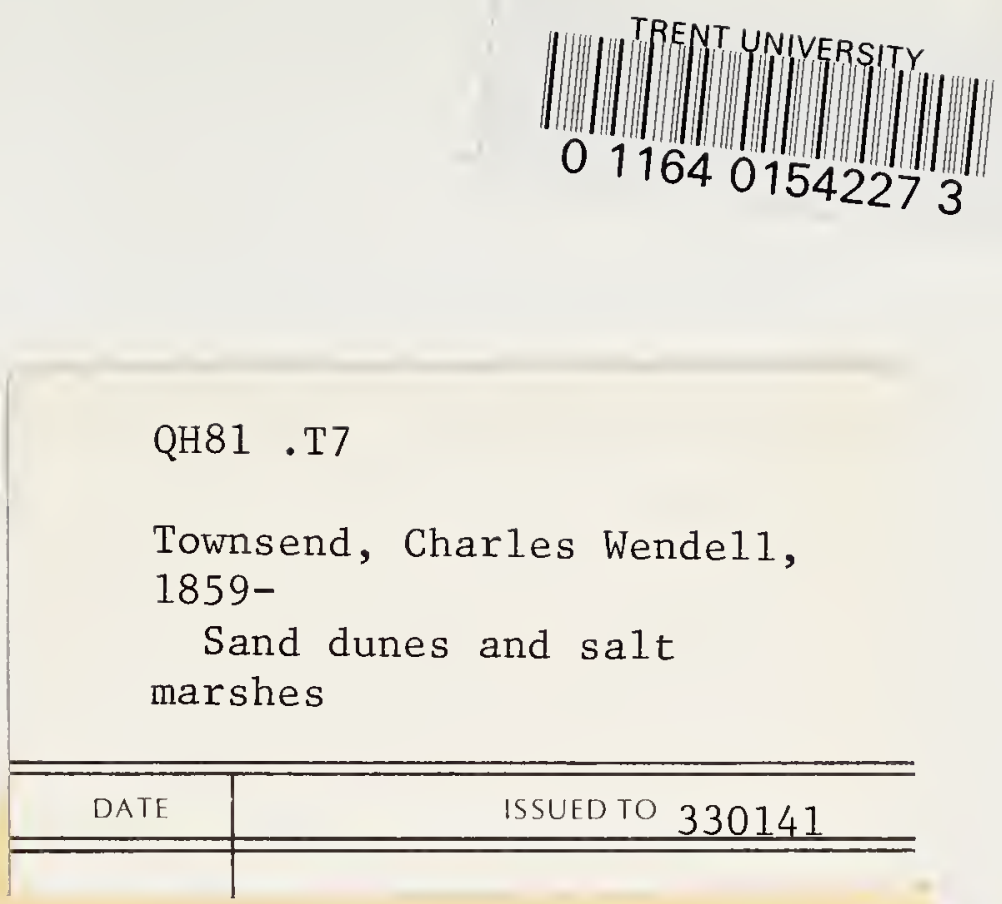

$$
330 \mathrm{k}
$$


